LUÍSA HELENA MACHADO RIBEIRO

"RISCO DE MERCADO NA COMERCIALIZAÇÃO DE ENERGIA ELÉTRICA: UMA ANÁLISE ESTRUTURADA COM FOCO NO AMBIENTE DE CONTRATAÇÃO LIVRE - ACL" 
LUÍSA HELENA MACHADO RIBEIRO

\title{
“RISCO DE MERCADO NA COMERCIALIZAÇÃO DE ENERGIA ELÉTRICA: UMA ANÁLISE ESTRUTURADA COM FOCO NO AMBIENTE DE CONTRATAÇÃO LIVRE - ACL”
}

\author{
Dissertação apresentada ao Departamento de \\ Engenharia de Energia e Automação Elétricas da \\ Escola Politécnica da Universidade de São Paulo \\ para obtenção do título de Mestre em Sistemas \\ de Potência
}

Orientador: Prof. Dr. Dorel Soares Ramos

São Paulo 


\title{
LUÍSA HELENA MACHADO RIBEIRO
}

\section{“RISCO DE MERCADO NA COMERCIALIZAÇÃO DE ENERGIA ELÉTRICA: UMA ANÁLISE ESTRUTURADA COM FOCO NO AMBIENTE DE CONTRATAÇÃO LIVRE - ACL”}

\begin{abstract}
Dissertação apresentada ao Departamento de Engenharia de Energia e Automação Elétricas da Escola Politécnica da Universidade de São Paulo para obtenção do título de Mestre em Sistemas de Potência

Área de Concentração: Sistemas de Potência Energia
\end{abstract}

Orientador: Prof. Dr. Dorel Soares Ramos 
Este exemplar foi revisado e corrigido em relação à versão original, sob responsabilidade única do autor e com a anuência de seu orientador.

São Paulo, 14 de outubro_de 2015.

Assinatura do autor:

Assinatura do orientador:

Catalogação-na-publicação

RIBEIRO, Luísa Helena Machado

RISCO DE MERCADO NA COMERCIALIZAÇÃO DE ENERGIA ELÉTRICA: UMA ANÁLISE ESTRUTURADA COM FOCO NO AMBIENTE DE CONTRATAÇÃO LIVRE - ACL / L. H. M. RIBEIRO -- versão corr. -- São Paulo, 2015.

$201 \mathrm{p}$.

Dissertação (Mestrado) - Escola Politécnica da Universidade de São Paulo. Departamento de Engenharia de Energia e Automação Elétricas.

1.Comercialização de Energia 2.Riscos 3.Fontes de Geração Sazonais e Intermitentes 4.Complementaridade energética I.Universidade de São Paulo. Escola Politécnica. Departamento de Engenharia de Energia e Automação Elétricas II.t. 
Dedico este trabalho aos meus pais Marcos Vinícius e Telma que sempre me apoiaram, acreditaram no meu sucesso ao enfrentar esse desafio e incentivaram para que eu chegasse mais longe que seus olhares pudessem enxergar. 


\section{AGRADECIMENTOS}

Ao professor Dr. Dorel Soares Ramos, pelo compartilhamento de sua experiência, orientação, incentivo e ensinamentos.

Ao meu marido Daniel, aos meus pais e irmãos, por todo apoio, incentivo e compreensão durante todo o período dedicado à realização desse trabalho.

À AES Tietê, pelo incentivo, compreensão e contribuição ao desenvolvimento do presente trabalho.

À banca de Qualificação, Dra. Rosana Santos e Dr. Roberto Castro, pelas orientações que aprimoraram o conteúdo e garantiram maior objetividade ao trabalho.

A todos os amigos e colegas que estiveram presentes nessa fase. 


\section{RESUMO}

A motivação para o desenvolvimento desse trabalho surge em um momento em que se verifica uma participação cada vez mais significativa das fontes energéticas renováveis não convencionais no País. Não obstante, o cenário de evolução evidencia que o arcabouço regulatório e as regras de mercado não acompanharam as especificidades inerentes à exploração dessas fontes. Assim, para que se mantenha adequado ritmo de inserção na matriz energética, devem ser buscadas opções para que fontes alternativas sejam cada vez mais competitivas na atual configuração do mercado energético. A contribuição dessa pesquisa, portanto, centra-se na análise dos riscos de mercado incorridos por esses geradores de fontes intermitentes de energia ao comercializarem energia no ambiente de contratação livre. Nessa perspectiva, a Dissertação foi desenvolvida abordando tipos de geração de energia e suas características técnicas e econômicas, legislação do setor elétrico, regras de comercialização, balanço energético do sistema, formação de preços no mercado de curto prazo e precificação de contratos no ACL, diferença de preços entre submercados, requisitos de flexibilidade e sazonalidade nos contratos de venda a consumidores livres e seu impacto na precificação de contratos, identificação de comportamento energético complementar para mitigação de riscos de mercado entre fontes renováveis e rebatimento na formulação de mecanismo de "hedge", análise de portfólio de contratos e estratégia ótima de contratação de energia para agentes geradores atuando no ACL. Como resposta ao desafio de equacionar o impasse surgido na comercialização de fontes de produção sazonal, propõe-se um modelo para definir estratégias de contratação para agentes geradores e comercializadores a partir da complementação energética entre diferentes tipos de fontes, de forma a maximizar os ganhos de comercialização para um risco estabelecido. Busca-se a composição ideal dessas fontes na carteira de um comercializador para minimizar o risco de exposição à volatilidade dos preços do mercado de curto prazo. Isso é possível em virtude das compensações energéticas feitas entre as diferentes fontes em um portfólio combinado, mitigando a receita em risco decorrente das variações que existem nos preços de curto prazo e na produção energética. De forma complementar, estruturou-se um modelo de negócio no qual uma empresa detentora de ativos de geração hidrelétrica compra os direitos de produção de uma eólica e/ou biomassa para incorporar ao seu portfólio e vender como contrato "por quantidade". Determinou-se o volume de energia a ser comprado de cada fonte, o preço, a estratégia mais indicada de contratação e a mitigação de fatores de risco contemplados nos contratos de venda, buscando maximizar os ganhos de comercialização condicionada a critérios de risco pré-fixados.

Palavras-chave: Energia Renovável; Risco; Complementaridade; Geração intermitente. 


\begin{abstract}
The motivation to write this thesis has arisen at a time when the participation of nonconventional renewable sources in the Brazilian electric energy matrix has become more significant. However, the scenario of the regulatory framework and market rules has not followed the specificity of the nature of these sources. In order to maintain a higher growth rate in the national electric matrix, non-conventional renewable sources must find alternatives to the current electric market. The contribution of this study focuses on the market risks analysis incurred by intermittent energy sources to commercialize energy in the free market. From this perspective, the study was developed addressing types of power generation and its technical and economic characteristics, legislation in the electricity sector, commercialization rules, system energy balance, spot market and long term contract pricing, difference prices between submarkets, flexibility requirements and seasonality in sales contracts to free consumers and their impact on contract pricing, identify complementary energy behavior for mitigating market risks from renewable sources and formulation of "hedge" mechanism, portfolio analysis and optimal strategy of energy contracting for generating agents acting in the ACL. In response to the challenge of solving the impasse in the commercialization of seasonal production sources, a model for contracting strategies was proposed for generation companies and retailer agents from the energy complementation between different types of sources in order to maximize the gains of marketing to an established risk. This allows revenues increase while mitigating risks in a scenario where spot prices and energy production vary greatly. An arrangement that provides the minimum risk was identified for retailer portfolio. This is possible due to differences amongst each source considered in the simulations, compensating the results in a diversified portfolio. As a complement, a business model was structured in which a generation company with hydro power assets purchases production rights of a wind and / or biomass to incorporate to its portfolio and sell as contract "for quantity." It was determined the amount of energy to be purchased from each source, the price, the best contracting strategy and mitigation of risk factors included in sales contracts, seeking to maximize the revenue giving an acceptance of risk.
\end{abstract}

Key-words: Renewable Energy. Risk. Complementary. Intermittent Electric Power. 


\section{LISTA DE SIGLAS}

ACL Ambiente de Contratação Livre

ACR Ambiente de Contratação Regulada

ANEEL Agência Nacional de Energia Elétrica

BEN Balanço Energético Nacional

CAR Curva de Aversão ao Risco

CCC Conta de Consumo de Combustíveis

CCD Contrato de Conexão ao Sistema de Distribuição

CCEE Câmara de Comercialização de Energia Elétrica

CCEAR Contrato de Compra de Energia no Ambiente Regulado

CCT Contrato de Conexão ao Sistema de Transmissão

CDE Conta de Desenvolvimento Energético

CEE Certificado de Energia Elétrica

CME Custo Marginal de Expansão do Sistema

CMO Custo Marginal de Operação do Sistema

CMSE Comitê de Monitoramento do Sistema Elétrico

CONUER Contrato de Uso da Energia de Reserva

CONER Conta de Energia de Reserva

CNPE Conselho Nacional de Política Energética

CUSD Contrato de Uso do Sistema de Distribuição

CUST Contrato de Uso do Sistema de Transmissão

CVaR Conditional Value at Risk

EER Encargo de Energia de Reserva

EPE Empresa de Pesquisa Energética

ICB Índice de Custo Benefício

GF Garantia Física

LER Leilão de Energia de Reserva

LEE Leilão de Energia Existente

LEN Leilão de Energia Nova

MCP Mercado de curto Prazo

MME Ministério de Minas e Energia

MP Medida Provisória 
MRE Mecanismo de Realocação de Energia

NC Nível de Contratação

ONS Operador Nacional do Sistema

PCH Pequena Central Hidrelétrica

PdC Procedimento de Comercialização

PDE Plano Decenal de Energia

PIE Produtor Independente de Energia Elétrica

PLD Preço de Liquidação das Diferenças

PMO Programa Mensal de Operação

PNE Plano Nacional de Energia

PROINFA Programa de Incentivo às Fontes Alternativas

RE-SEB Reestruturação do Setor Elétrico Brasileiro

SAR Superfície de Aversão ao Risco

SEB Sistema Elétrico Brasileiro

SIN Sistema Interligado Nacional

TP Teoria do Portfólio (Markowitz)

TUSD Tarifa de Uso do Sistema de Distribuição

TUST Tarifa de Uso do Sistema de Transmissão

VaR Value at Risk 


\section{SUMÁRIO}

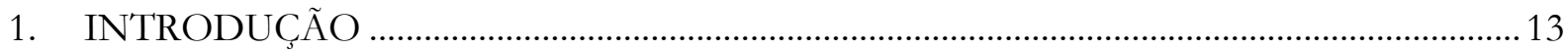

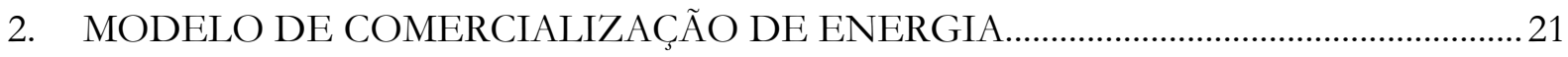

2.1 Retrospectiva Institucional e Regulatória do Setor Elétrico Brasileiro ....................................21

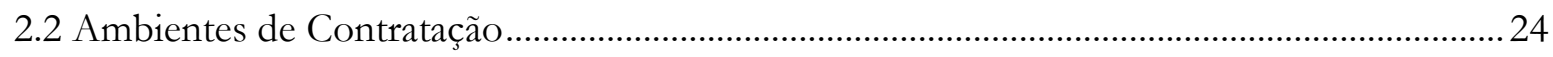

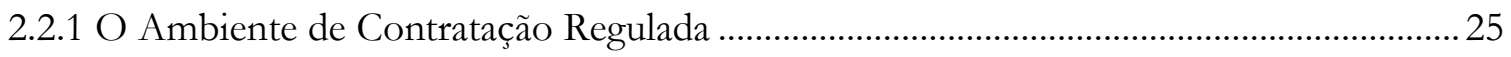

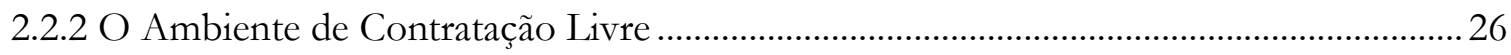

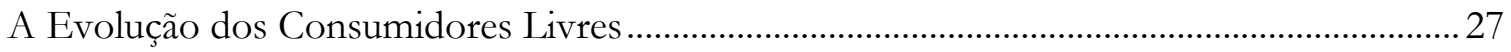

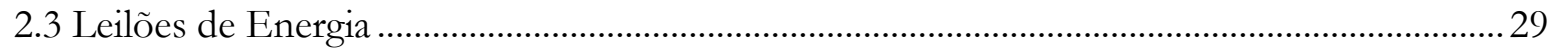

2.4 Relações contratuais e comerciais no modelo institucional vigente no setor elétrico............34

2.4.1 A natureza do contrato de compra e venda de energia elétrica.............................................. 35

2.4.2 Características de um contrato de energia ............................................................................... 36

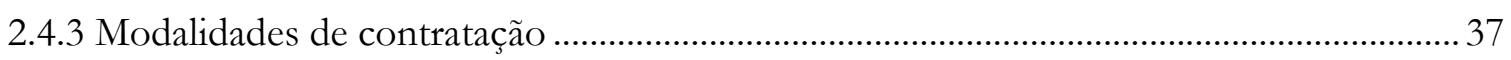

2.4.4 Contratos de leilões de energia nova (LEN) ....................................................................... 38

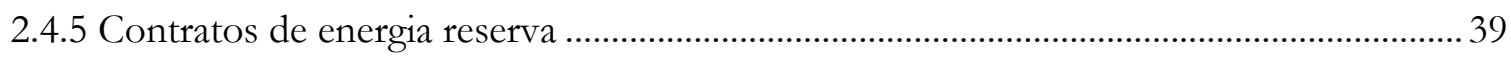

2.5 O mercado de curto prazo e o regime de complementação térmica ......................................... 41

2.6 Processo de contabilização e liquidação financeira ....................................................................... 47

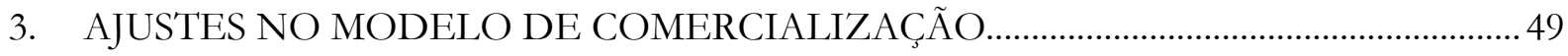

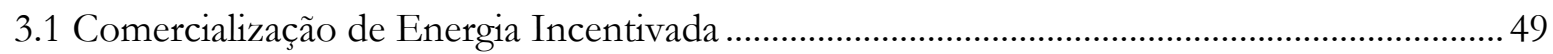

3.1.1 Preâmbulo: Programa de Incentivos às Fontes Alternativas de Energia Elétrica -

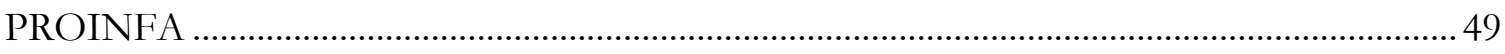

3.1.2 O Modelo de Comercialização de Energia Incentivada …………………….........................50

3.2 A Renovação das Concessões Vincendas e Redução da Tarifa de Energia.............................. 54

3.3 Introdução de Mecanismos de Aversão ao Risco nos Modelos Computacionais que definem o despacho hidrotérmico e a questão do custo do despacho térmico adicional............58

4. DEFINIÇÃO DE ESTRATÉGIA DE COMERCIALIZAÇÃO DE ENERGIA PARA

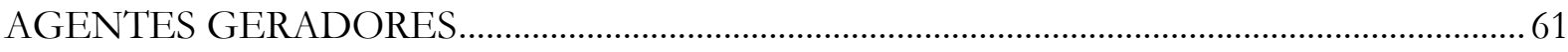

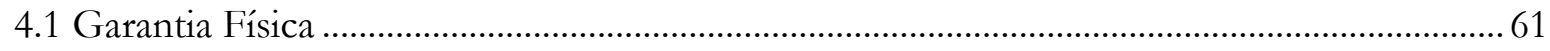

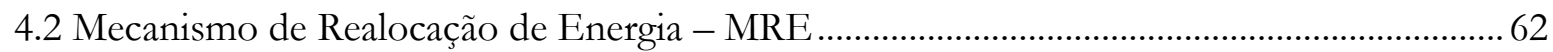

4.3 Precificação de Contratos no ACR: Índice de Custo/Benefício (Contratos por

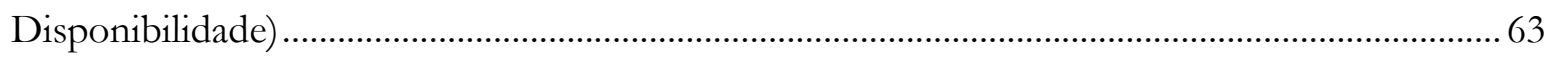

4.4 Precificação de Contratos no ACL (Custo de Oportunidade).....................................................68

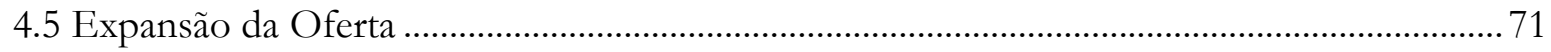


A expansão da energia renovável não convencional no ACL................................................... 74

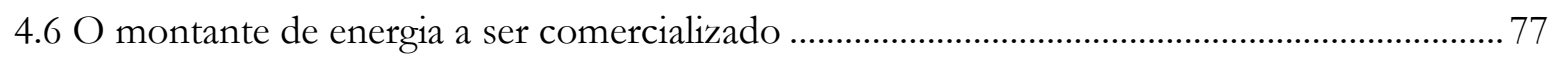

4.7 Características da Comercialização de Energia - Modelagem da Receita de Comercialização

4.8 Aspectos a serem considerados na elaboração da estratégia........................................................ 79

5. ENERGIA RENOVÁVEL NÃO-CONVENCIONAL - SAZONALIDADE E

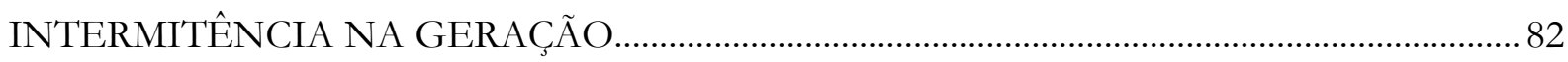

5.1 Volatilidade da Geração Eólica ………………....................................................................... 83

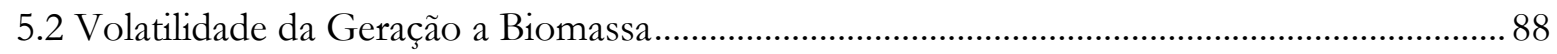

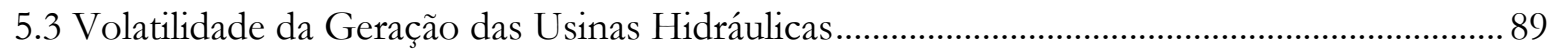

5.4 Complementaridade entre cogeração de cana, usinas eólicas e a produção de pequenas

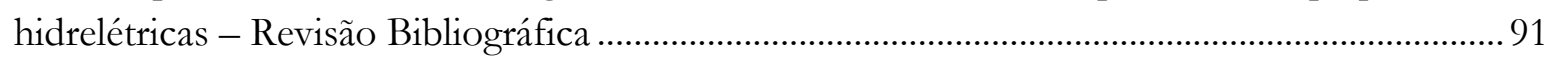

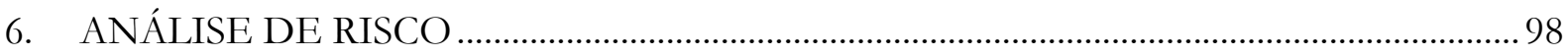

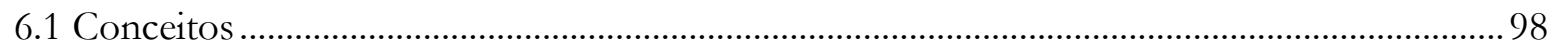

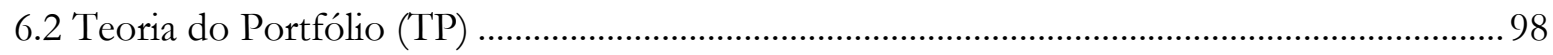

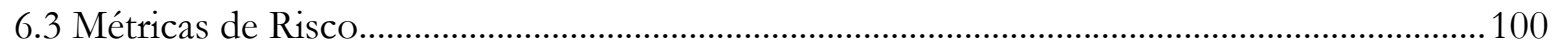

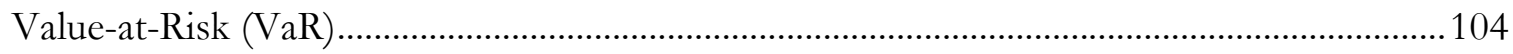

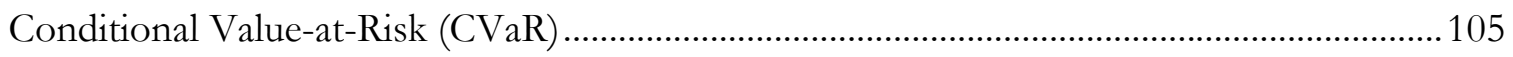

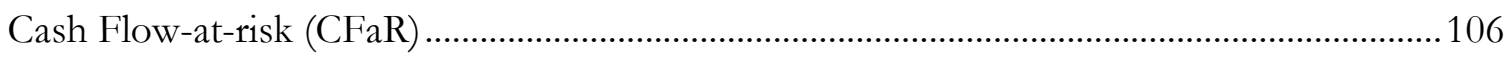

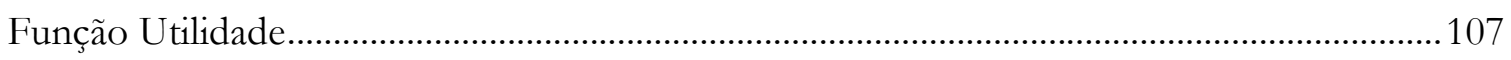

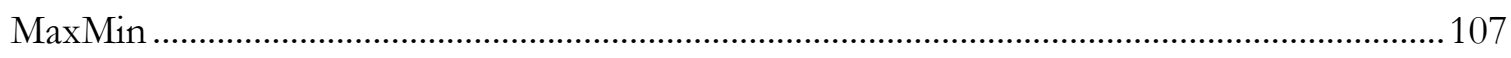

6.4 Precificação de ativos e negócios em energia ................................................................................. 107

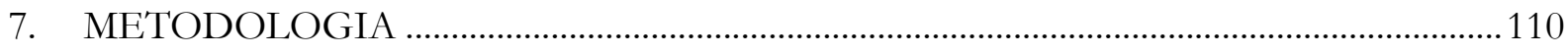

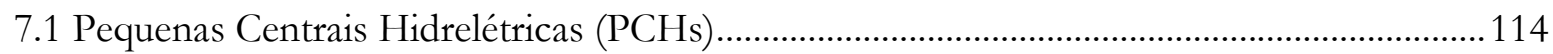

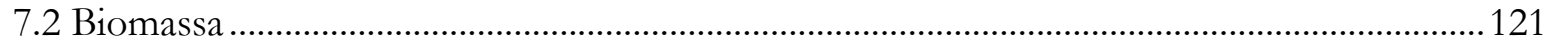

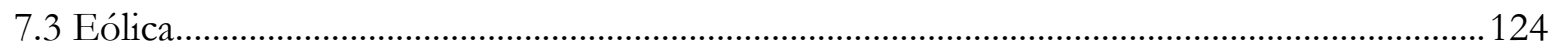

7.4 Um novo negócio: mistura de padrões de produção …………………………......................128

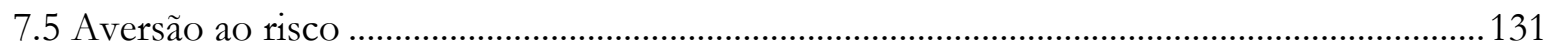

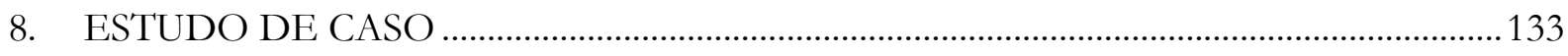

8.1. Descrição das situações a serem simuladas ..............................................................................133

8.2. Análise I - Portfólio de um Gerador - Resultados ....................................................................134

8.3 Análise II - Portfólio de um Comercializador - Resultados .................................................137

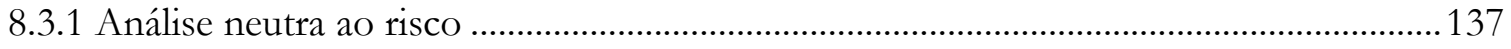

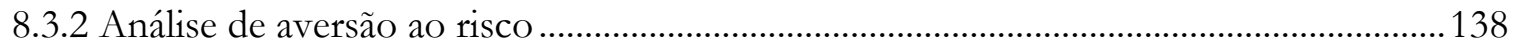

9. CONSIDERAÇÃO DOS FATORES DE RISCO DE MERCADO.....................................141 


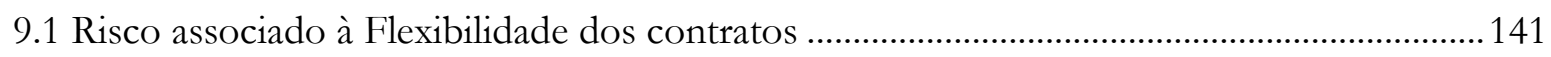

9.2 Risco associado a diferenças de preços entre submercados.................................................... 143

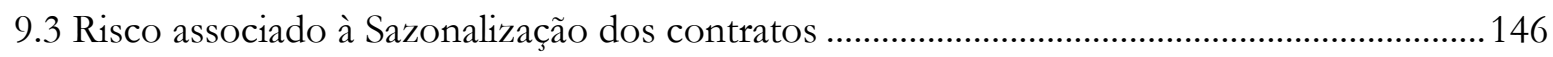

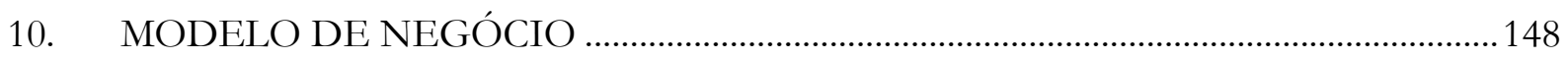

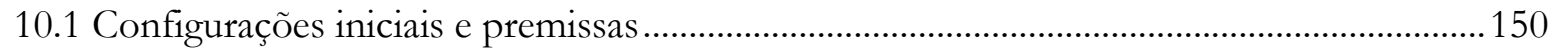

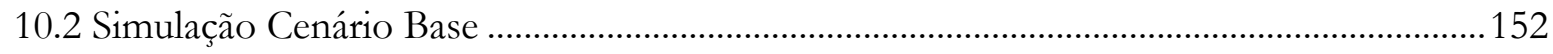

10.3 Sensibilidade de Garantia Física da Fonte Eólica ...................................................................

10.4 Sensibilidade do Preço de Venda da Energia .......................................................................... 161

10.5 Sensibilidade de Condições de Partida do Sistema................................................................165

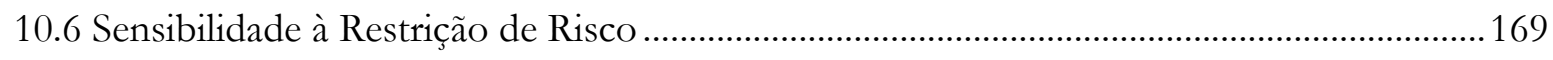

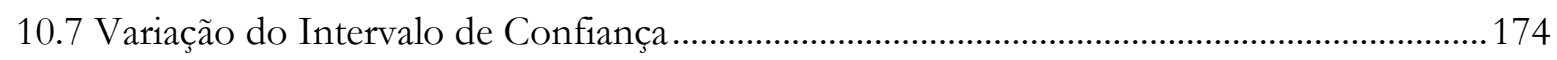

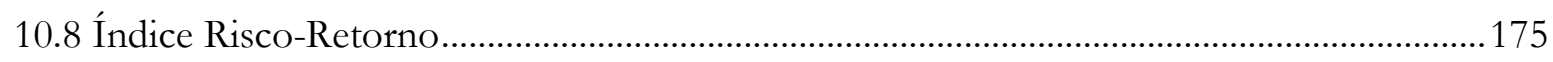

10.9 Simulação do Portfólio final com contratos com cláusulas de flexibilidade e sazonalidade

10.10 Estratégia de sazonalização da Garantia Física da hidrelétrica para fins de alocação de energia no MRE no Portfólio final ...........................................................................................179

11. VARIAÇÃO DO MODELO DE NEGÓCIO PROPOSTO ..........................................182

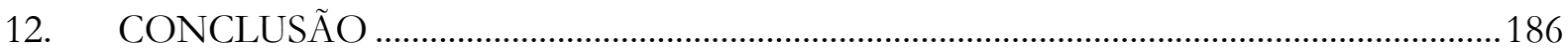

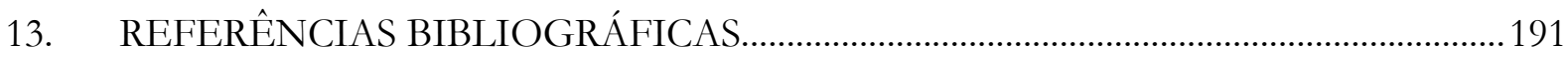

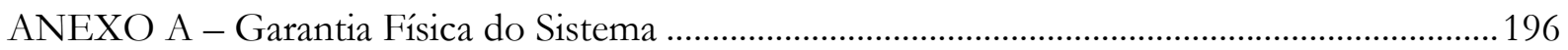




\section{INTRODUÇÃO}

O parque gerador brasileiro é formado em sua maior parte por grandes centrais hidrelétricas, cujo despacho centralizado objetiva o pleno atendimento à carga, utilizando a capacidade de produção de forma ótima, ou seja, ao menor custo global. Isso significa que não apenas o custo e as condições imediatas devem ser considerados, mas também a capacidade de atendimento à demanda futura, uma vez que existe grande variação na disponibilidade energética devido à sazonalidade das afluências. Neste contexto, usinas térmicas representam um papel fundamental em sistemas com grande participação de fontes cuja disponibilidade é sazonal, complementando a produção de energia em situações adversas.

No entanto, a utilização de usinas térmicas como única alternativa às fontes hidrelétricas significa caminhar no sentido contrário das atuais políticas energéticas mundiais, que pregam a diversificação e preservação do meio ambiente na expansão da matriz energética. Fontes renováveis surgiram recentemente como uma opção de geração para muitos países, a fim de promover o desenvolvimento de energia "limpa". No caso do Brasil, eólicas e cogeração de bagaço de cana têm sido alternativas atraentes nos últimos anos, pois possuem potencial significativo para nova capacidade, menor tempo de construção, o que é de suma importância, haja vista a incerteza no crescimento da demanda e a existência de períodos com taxas de crescimento bastante significativas.

Outro ponto que corrobora com a necessidade de diversificação da matriz refere-se ao fato de que a capacidade de regularização do SIN vem diminuindo a cada ano, em virtude da construção de UHEs cujos reservatórios possuem baixa ou nenhuma capacidade de regularização anual, como é o caso das usinas do Rio Madeira, onde a variabilidade de geração é da ordem de 5.000 MWmed entre os períodos úmido e seco.

De acordo com dados do ONS, nos próximos cinco anos, a capacidade de armazenamento irá crescer $1,2 \%$, versus um crescimento na carga de $20 \%$. Tal fato irá tornar o Sistema cada vez mais dependente de períodos chuvosos para enchimento de seus reservatórios, com variações nos níveis de armazenamento cada vez maiores ao final dos períodos de seca. Por isso, as fontes alternativas irão representar um papel fundamental na manutenção das condições de fornecimento e na segurança do suprimento energético (2) 
O forte desenvolvimento da fonte eólica tem estimulado a investigação de melhorias dos métodos de planejamento de operação do sistema, a fim de lidar com uma fonte de energia que não pode ser despachada no sentido clássico - por causa de sua dependência intrínseca de diferentes condições meteorológicas, que tornam a sua produção de energia com apreciável variabilidade ao longo do ano e intermitente no horizonte de atendimento da curva diária de carga. Em termos de potencial de produção sazonal, verificam-se valores significativamente acima da média em boa parte do período seco das hidrelétricas. O fato dos parques estarem localizado nas regiões Sul e Nordeste, enquanto a maioria dos consumidores se concentra no Sudeste, submete os geradores à diferença de preços entre submercados e introduz um problema técnico de solução bastante onerosa, que é a alocação de reserva de potência no sistema interligado.

O principal desafio para o desenvolvimento massivo das pequenas centrais hidrelétricas e usinas a biomassa no Brasil reside menos na parte técnica - a operação dessas usinas pode ser despachável, no montante que eventualmente não esteja vinculado ao processo de produção de calor em andamento (no caso da cogeração a biomassa), de toda forma um despacho previsível com antecedência, ao invés de intermitente (como a eólica) - e mais no aspecto comercial. De fato, não obstante essa característica, do ponto de vista comercial estas alternativas também são prejudicadas pela sazonalidade de seu recurso.

As usinas de cogeração a bagaço de cana têm uma produção de energia sazonal (inflexível), que ocorre apenas durante o período de colheita. Ao comercializarem sua energia na modalidade de contratos "flat", ficam expostas no mercado spot nos meses sem produção, o que pode vir a ser um componente da despesa impeditivo para qualquer investidor avesso ao risco. Nestes casos, no mercado livre, os produtores são forçados a contratar energia de terceiros a preço de mercado para atendimento de requisitos de suprimento e, por isso mesmo, correm risco ao vender contratos firmes de energia (ou seja, assumem os riscos de compra no mercado spot sempre que sua produção é menor que o valor contratado), isso implica que os empreendimentos, por si só, em geral não são comercialmente atraentes.

No caso das usinas hidrelétricas, participar do Mecanismo de Realocação de Energia - MRE já é caracterizado como hedge ${ }^{1}$, pois trata-se de um esquema de compartilhamento de riscos

\footnotetext{
${ }^{1}$ Hedge: denominação comumente usada no mercado financeiro que significa proteger ou cobrir um determinado ativo contra perda de valor no futuro devido a oscilações no mercado. O termo tem sido usado também pelo mercado de energia, dada a semelhança com mercados financeiros em algumas de suas operações, em especial na
} 
hidrológicos implementado para corrigir a distorção na alocação dos benefícios econômicos aos agentes cujas usinas hidroelétricas estão em cascata.

A operacionalização do MRE consiste em fazer com que a alocação de energia a cada usina atinja a mesma proporção de garantia física naquele período de comercialização. Quando a energia total produzida pelas usinas do SIN é superior à garantia física total, esse superávit de energia é denominado Energia Secundária e é rateado entre todas as usinas participantes do mecanismo, na proporção de sua garantia física. Em contrapartida, caso o sistema como um todo apresente déficit, as usinas terão suas garantias físicas para fins de contabilização da CCEE reduzidas proporcionalmente.

Uma das implicações deste esquema é que os proprietários das usinas hidroelétricas não são afetados pelas decisões operativas do ONS (despacho é centralizado), pois seu pagamento "spot" na CCEE está associado à geração total do sistema hidroelétrico, não a sua geração física individual. Vale ressaltar ainda que, como a geração física total do sistema hidroelétrico é muito mais constante do que a produção individual, o MRE ajuda a reduzir a volatilidade dos pagamentos "spot" na CCEE. No entanto, a correlação entre a geração hidrelétrica e os preços no mercado de curto prazo é extremamente negativa.

Entretanto, o condicionante de salvaguarda dos investidores contra os riscos inerentes ao negócio e o crescente aporte de investimentos em fontes alternativas, incentivam os grandes geradores e comercializadores a analisarem o efeito da complementaridade entre a sazonalidade de geração dessas fontes, tendo em vista a definir estratégias de investimento e comercialização, de tal forma a capturar esse efeito e auferir ganhos adicionais de receita, do que se comercializassem separadamente a energia gerada individualmente por ativo. Ao considerar os ativos num mesmo portfólio, a sazonalidade de geração pode resultar em "hedge" natural para a comercialização da garantia física de cada um deles e, assim, funcionar como um mecanismo de mitigação de risco, permitindo a tomada de iniciativas mais arrojadas e que trazem maiores ganhos à empresa, sem se expor aos riscos ocasionados por fatores de pouca ou nenhuma gestão.

A estratégia de comercialização requer também a definição da contratação da energia nos ambientes de comercialização institucionalizados no marco regulatório do setor elétrico

mitigação de risco no mercado de curto de prazo, em virtude de exposições contratuais ou perda de lastro. Também pode ser interpretado como "margem de comercialização". 
brasileiro, de acordo com os aspectos de segmentação do mercado, as opções e os riscos dos agentes, bem como mecanismos de mitigação de riscos propiciados pela regulação vigente.

Com uma característica de geração tão peculiar do parque gerador nacional, a contratação de energia no ambiente livre atrai consumidores que buscam reduzir custos com a possibilidade de adquirir energia barata, muito embora enfrentando elevados riscos financeiros associados a essa operação, pois não há uma maneira de se prever de forma exata qual será a real disponibilidade energética em um horizonte de médio ou de longo prazo, tornando difícil precificar o valor da energia.

Por outro lado, para os agentes geradores, o problema é oposto, ou seja, torna-se bastante interessante o estabelecimento de contratos de longo prazo, como mecanismo de defesa para os preços baixos que ocorrem na maior parte do tempo, porém seria vantajoso estar com sua capacidade de produção descontratada nos momentos em que o preço de curto prazo (spot ou PLD) dispara, de modo a obter ganhos com a venda de energia a preços extremamente elevados. Neste caso, os riscos comerciais, no caso de energia hidrelétrica contratada, advêm das perdas de receita em situações de hidrologia adversa, quando a produção hidrelétrica é reduzida pela estiagem e o gerador hidrelétrico fica exposto a PLD (Preço de Liquidação das Diferenças) elevado no mercado de curto prazo. Por outro lado, a venda de geração acima da garantia física, quando as condições hidrológicas são favoráveis e o PLD está baixo, gera ganhos, muito embora inferiores às perdas.

Já o gerador termelétrico, responsável pela compra de combustível, paga os custos variáveis de operação e manutenção e se apropria dos ganhos de receita advindos da operação econômica do sistema hidrotérmico interligado. Esse ganho advém, em geral, da compra de energia elétrica no mercado de curto prazo, sempre que o custo marginal de operação (CMO) for inferior ao custo variável unitário (CVU) da usina. Nessa condição, o operador não despacha essa usina além do nível de inflexibilidade declarado pelo empreendedor e o fornecimento contratado é adquirido no mercado de curto prazo, permitindo atender suas obrigações contratuais sem incorrer em custos de combustível, que seriam mais elevados que o custo da energia adquirida no mercado de curto prazo.

Outro fator de risco relevante para o gerador termelétrico contratado é o de indisponibilidade forçada de longa duração. Se essa indisponibilidade ocorrer em períodos de hidrologia 
desfavorável, quando o PLD excede o custo variável unitário (CVU) do gerador termelétrico, este deverá comprar no mercado de curto prazo a diferença entre o montante contratado e a geração despachada pelo ONS. Em caso extremo, se a indisponibilidade for total, o montante contratado deverá ser integralmente adquirido no mercado de curto prazo.

Para fazer frente a esse risco, o gerador termelétrico considera, na formação de seu preço de oferta, um fator de capacidade elevado, que corresponde a um despacho na base da curva de carga, o que encarece muito e tira a competitividade da energia termelétrica. Assim, para este caso, foram instituídos Contratos de Comercialização de Energia no Ambiente Regulado por Disponibilidade de Energia, no qual o gerador disponibiliza uma quantidade máxima de energia, recebe uma receita anual fixa e assume os riscos de indisponibilidade acima da declarada. Os distribuidores pagam a receita anual e o combustível gasto em função de despacho econômico comandado pelo ONS. Esse pagamento é feito com base no CVU declarado pelo gerador no momento do leilão. Os distribuidores assumem os riscos de exposição no mercado de curto prazo, com repasse garantido às tarifas ${ }^{2}$.

Como se pode notar, grande parte dos riscos dos geradores de energia de fontes térmicas ou intermitentes é mitigado no ambiente de contratação regulado por meio dos contratos por disponibilidade, onde o distribuidor assume o risco de exposição. No caso de fontes intermitentes, como a eólica, há a obrigação de entrega da energia contratada com apuração mais flexível, em horizontes anuais e quadrienais, inclusive com mitigação completa da exposição ao preço do Mercado de Curto Prazo para o caso de plantas eólicas contratadas para Energia de Reserva.

Tal prerrogativa torna-se mais verdadeira, quando são considerados os riscos de flexibilidade, sazonalidade e diferença de submercado que são assumidos pelos geradores no ambiente de contratação livre.

\footnotetext{
${ }^{2}$ Os contratos por disponibilidade permitem que o Consumidor possa auferir a vantagem da operação em complementação térmica, na medida em que assume, na prática, o custo do combustível quando há acionamento e o custo de compra de energia no mercado de curto, quando a termelétrica não é despachada por mérito econômico. Considerando que na maior parte do tempo ( $95 \%$ do tempo, se o Sistema estiver bem ajustado em termos estruturais) os preços de curto prazo são relativamente baixos, a termelétrica tende a ser pouco acionada e a expectativa de custo de combustível tende a ser reduzida em relação a uma operação na base. Destarte, o consumidor será beneficiado economicamente pela diferença de preços entre o PLD (Preço de Liquidação de Diferenças, ou preço do mercado de curto prazo) e o CVU (Custo Variável Unitário) que deixa de ser incorrido.
} 
Porém, no Ambiente de Contratação Livre, o mercado de energia para consumidores especiais com carga entre $500 \mathrm{~kW}$ e $3 \mathrm{MW}$, que podem comprar eletricidade diretamente de fontes alternativas (eólicas, térmicas a biomassa, PCHs), está em destaque, com crescimento acentuado da demanda, que já preocupa por causa de um possível descompasso com a oferta nos próximos anos, uma vez que a maior parte da energia dessas fontes está contratada pelo Proinfa ou no ambiente regulado, sendo que o montante contratado no ACL representa menos de $20 \%$ de tudo o que está contratado no ACR.

Aqui se inicia o questionamento quanto à atratividade do ambiente de contratação livre para os agentes de geração de fontes térmicas, eólicas, ou mesmo hidráulicas, tendo em vista os riscos de mercado que esses agentes incorrem.

Para auxiliar na apresentação deste trabalho, nos Capítulos 2 a 4 será explorado o modelo de comercialização de energia no Brasil, com ênfase nos ambientes de contratação livre e regulada, formas de contratação e relações contratuais e comerciais. Adicionalmente, será explicada a formação de preços nos dois ambientes, bem como a fundamentação por trás de conceitos como Custo Marginal de Expansão (CME), Custo Marginal de Operação (CMO) e Preço de Liquidação das Diferenças (PLD). O capítulo 3 apresentará a evolução das fontes renováveis não convencionais no Brasil, desde as primeiras tentativas do governo de introdução na matriz energética nacional, passando pelos marcos regulatórios primordiais para sua evolução e consolidação. Essas fontes têm a característica de serem de porte menor do que as convencionais exploradas no País $^{3}$ e ainda se encontram em fase de consolidação da cadeia produtiva, razão pela qual são necessários subsídios do governo, ou incentivos, para torná-las comercialmente atrativas.

O Capítulo 5 discorrerá sobre energia renovável não convencional, destacando a volatilidade de sua geração e a complementação entre estas fontes alternativas exploradas comercialmente. Serão apresentadas as características de geração e sazonalidade de oferta de energia das PCHs, BIO e EOL. A partir dessas características, será possível identificar potenciais de complementação em diferentes arranjos. Existe hoje uma concentração de tipos específicos de fontes em algumas regiões do país, o que confere uma parcela significativa de incerteza à energia disponível, pois um evento atmosférico ou climático adverso locacional pode comprometer a oferta energética da

\footnotetext{
${ }^{3}$ As grandes usinas como as tradicionais Hidrelétricas e Termelétricas apresentam uma economia de escala, o que favorece na diminuição do custo do megawatt-hora gerado. Dessa forma, as fontes renováveis não convencionais, por serem tipicamente de menor porte, não possuem tal vantagem e demandam algum outro tipo de incentivo para se tornarem atrativas do ponto de vista comercial.
} 
região, exigindo manobras de cunho emergencial e sobrecarregando os sistemas de transmissão, podendo ocasionar custos adicionais ao sistema. Dessa forma, a possibilidade de diversificação de fontes dentro do mesmo submercado, pode trazer ganhos energéticos para os sistemas e, consequentemente, financeiros à operação. Entretanto, medidas de amplitude nacional, que incentivem a diversificação, podem surgir em uma velocidade diferente daquela que o investidor necessita. Dessa forma, é natural que a iniciativa de investir em fontes complementares venha do próprio investidor, o qual pode se beneficiar da redução do risco e ganho no retorno propiciado por um portfólio diversificado (3).

O Capítulo 6 discorrerá sobre a análise de risco, introduzindo conceitos e métricas necessários ao desenvolvimento do instrumental de análise de Risco de Mercado para formulação e elaboração da modelagem da estratégia de comercialização de fontes de produção intermitentes no mercado livre.

Em seguida, no Capítulo 7, será feita a descrição da modelagem física e comercial das fontes de geração. A modelagem do problema utilizou como dados de entrada a potência instalada, fator de capacidade, perfil sazonal de geração das usinas renováveis e séries históricas de geração e preços spot para obter a melhor alocação de cada fonte em um portfólio, de forma a maximizar a receita do agente no período de estudo, dado um nível de aceitação de risco, medido pelo VaR (Value at Risk) e CVaR (Conditional Value at Risk). Especificamente no caso da eólica, serão consideradas séries históricas de vento reconstituídas.

No Capítulo 8 serão realizadas duas análises, a primeira do ponto de vista do gerador, detentor de ativos de pequenas centrais hidrelétricas, usinas eólicas e de biomassa balanceadas em potência, e a segunda foca-se no comercializador, que firmará contratos de capacidade com estas fontes, de forma que as proporções de cada fonte em seu portfólio sejam tais que minimizem o risco do agente, segundo o modelo de Markowitz para carteiras com mais de dois ativos com risco. Para ambos os agentes, o objetivo será maximizar a receita da venda da garantia física das três fontes, para um determinado critério de risco, por meio da definição do montante de energia disponibilizado para contratação.

No Capítulo 9 os fatores de risco dos contratos, tais como flexibilidade, sazonalidade e risco oriundo da venda de energia em submercado diferente do local de geração, serão modelados e precificados, de forma a acrescentar uma margem de risco ao preço final de venda, fazendo com 
que seja indiferente, dado um critério de risco, realizar um contrato de venda de energia sem o fator de risco a um preço $\mathrm{X} \mathrm{R} \$ / \mathrm{MWh}$ e vender com o fator de risco a um preço $\mathrm{X}+\mathrm{M}$ $(\mathrm{R} \$ / \mathrm{MWh})$.

No Capítulo 10, será estruturado um modelo de negócio, no qual uma empresa detentora de ativos de geração hidrelétrica compra os direitos de produção de uma eólica e/ou de uma biomassa (contrato por capacidade) para incorporar em seu portfólio e vender em forma de contrato "por quantidade" em energia firme. A questão para a empresa será determinar a quantidade de energia a ser comprada de cada fonte, o preço de compra para que seja possível revendê-la a um preço definido através de um contrato por quantidade com consumidor livre. Ao adquirir a "curva de geração" da eólica e/ou biomassa, incorporando a sua Garantia Física existente e negociando a venda do total de lastro disponível, o gerador assume todos os riscos de mercado na comercialização e, por consequência, mitiga completamente os riscos de mercado do empreendedor da eólica e/ou cogeração. Deve ser analisada ainda a estratégia mais indicada de contratação da produção garantida do empreendimento conjunto, quantificando-se as receitas que podem ser auferidas para cada nível de contratação, de forma a maximizar os ganhos de comercialização sob condicionamento de critérios de risco pré-fixados.

Uma variação do modelo de negócio anterior será proposta no Capítulo 11, de forma a utilizar a garantia física da empresa detentora de ativos de geração hidrelétrica para complementação da disponibilidade energética do portfólio de energia eólica e/ou biomassa, adquirido da compra de contratos de capacidade, sem a mistura da energia, apenas para hedge financeiro da exposição ao mercado spot.

Uma geração que tenha um comportamento estável, ou "flat", proporciona ao investidor uma vantagem em relação aos demais agentes vendedores do mercado, pois este se protege de oscilações que acontecem no preço de energia do mercado, mais bruscamente no curto prazo, mas também perceptível em contratos de longo prazo. Essa proteção é decorrente da possibilidade de complementar a oferta energética sazonal com usinas do próprio portfólio ou por meio da aquisição da curva de geração de usinas de outros empreendedores, permitindo a tomada de iniciativas mais arrojadas e que trazem maiores ganhos à empresa, sem se expor aos riscos ocasionados por fatores de pouca ou nenhuma gestão, tais como atraso do período chuvoso, escassez de ventos, indisponibilidade de combustível e atraso na entrega de subestações. 


\section{MODELO DE COMERCIALIZAÇÃO DE ENERGIA}

\subsection{Retrospectiva Institucional e Regulatória do Setor Elétrico Brasileiro}

Os Sistemas Elétricos de Potência apresentam portes gigantescos, possuindo um número elevado de usinas, milhares de quilômetros de linhas de transmissão, além de uma infinidade de subestações e centros de controle. A complexidade e os elevados custos envolvidos no gerenciamento de todos estes equipamentos têm sido responsáveis por significativos esforços de empresas, centros de pesquisa e universidades de várias partes do mundo, cujos objetivos são encontrar técnicas seguras e eficientes para operar e expandir os Sistemas de Energia Elétrica.

De forma complementar, além dos aspectos técnicos citados, é necessário que ambientes comerciais sejam implementados de forma a atrair investimentos para garantir a expansão necessária, atentando-se para os aspectos de garantia de suprimento, garantia de acesso e modicidade tarifária.

Desde a década de 90 o setor elétrico brasileiro vem se desenvolvendo e se modificando de forma a aprimorar seus dispositivos de incentivo aos investimentos e de estímulo à eficiência operacional. As grandes alterações do setor elétrico durante a década de 1990 tinham como objetivo buscar a garantia de expansão do parque gerador, além de atrair investimentos privados, uma vez que o governo sinalizava a falta de capacidade de investir o montante necessário para acompanhar a previsão de crescimento da demanda por energia elétrica.

O início das reformas dos anos 90 foi marcado pela promulgação da Lei nº 8.631/93, que dispôs sobre a fixação dos níveis das tarifas para o Serviço Público de Energia Elétrica, extinguindo o regime de remuneração garantida e da equalização tarifária, além da criação dos contratos de suprimentos entre geradores e distribuidores.

Na sequência, podem ser destacados marcos importantes tais como em 1995, com a promulgação da Lei $n^{\circ} 9.074$, lei de estímulo à participação da iniciativa privada no setor de geração de energia elétrica, marco inicial da competição na comercialização de energia elétrica com o surgimento do conceito de Consumidor Livre e em 1996 com a implantação do Projeto de Reestruturação do Setor Elétrico Brasileiro (RE-SEB), preconizando alterações que previam a desverticalização do 
setor. Também foram previstos órgãos responsáveis pela regulamentação do setor, pela expansão, pela operação e pela liquidação das operações comerciais.

O Modelo Institucional vigente do Setor Elétrico Brasileiro veio para consolidar as reformas supracitadas. Um dos pilares da formulação do novo modelo foi o resgate da função Planejamento da Expansão, derivando daí a criação da Empresa de Pesquisa Energética (EPE), responsável por desenvolver estudos e pesquisas de planejamento energético. Para atender ao preceito da prioridade na segurança de abastecimento, estabeleceu-se o Comitê de Monitoramento do Setor Energético (CMSE), com função de avaliar a segurança do suprimento de energia elétrica e, na vertente da comercialização de energia, foi criada a Câmara de Comercialização de Energia Elétrica (CCEE), ambiente de realização de compra e venda de energia elétrica.

Para atingir os objetivos de garantir a segurança de suprimento de energia elétrica e promover a modicidade tarifária, foram adotados dois princípios básicos: estabelecimento de competição nos segmentos de geração e comercialização para consumidores livres, com o objetivo de estimular o aumento da eficiência e redução dos preços; estabelecimento de monopólios regulados nas atividades de transmissão, distribuição e comercialização para consumidores cativos (no caso das redes, trata-se de monopólios naturais, e no caso dos pequenos consumidores, entendia-se que, naquele momento, não existiam condições de natureza prática para definir tais consumidores como elegíveis ao mercado livre).

A coexistência de setores regulados e competitivos foi (e ainda é) um dos principais desafios na implementação de reformas no setor elétrico. Seu equacionamento requer a adoção das seguintes medidas: regulação por incentivos dos segmentos de monopólio natural, através de ações que estimulem a eficiência e modicidade dos preços dos segmentos regulados, visando o livre acesso às redes de transmissão e distribuição, de forma a permitir efetivamente a competição na geração e comercialização; defesa da concorrência, por meio da regulação de conduta e da estrutura, para coibir o exercício de poder de mercado.

A atividade de geração restou plenamente aberta à competição e estritamente não regulada economicamente, sendo que todos os Geradores passaram a ter livre acesso ao sistema de transmissão e distribuição de energia. A energia vinculada a esses Geradores pode ser 
comercializada a preços livremente negociados, porém as condições técnicas são reguladas e o montante efetivo de geração física (despacho das usinas) é determinado pelo Agente Operador.

As linhas de transmissão de energia elétrica podem ser utilizadas por qualquer Agente, com a devida remuneração ao proprietário por meio da tarifa do uso do sistema de transmissão. No entanto, tem se verificado atraso nas novas linhas de transmissão e conexões concedidas em pontos muito distantes e não econômicos. Como o transporte de energia é uma atividade caracterizada pelo conceito de monopólio natural, está sujeita a uma regulamentação técnica e econômica. Além disso, os novos projetos de transmissão devem ser concedidos por licitação, eliminando a reserva geográfica da área de concessão.

A atividade de distribuição de energia elétrica continuou regulada técnica e economicamente. Todos os Agentes passaram também a ter acesso livre à rede, mediante pagamento da Tarifa de Uso do Sistema de Distribuição e Transmissão, o que permitiu viabilizar a comercialização de energia elétrica ao mercado livre.

Surgiu a figura do comercializador de energia, responsável pela compra e venda de energia elétrica a todos os Agentes, a preços livremente negociados. Esta atividade é regulada somente tecnicamente.

O autoprodutor é a empresa que possui autorização para produzir energia elétrica para consumo próprio e vender o excedente às concessionárias de energia elétrica e/ou ao Mercado de Curto Prazo. Produtor independente caracteriza-se pela concessão ou autorização para produzir energia elétrica destinada ao comércio de toda ou parte de sua produção. Ao mesmo tempo, criou-se a figura do consumidor livre que pode adquirir energia elétrica de qualquer fornecedor, conforme legislação específica.

A regulamentação da comercialização de energia elétrica foi estabelecida pelo Decreto 5.163 de 2004. Na comercialização de energia elétrica, algumas condições devem ser obedecidas, objetivando o atendimento das premissas estabelecidas pela Lei 10.848. Uma dessas condições é a apresentação de cem por cento de lastro para todos os agentes do mercado. Os agentes vendedores sejam estes geradores de serviço público, produtores independentes, autoprodutores ou comercializadores devem apresentar lastro de energia e potência para garantia de seus contratos. O lastro será constituído por garantia física de empreendimentos de geração próprios 
ou de terceiros, neste caso comprovada através da celebração de contratos de compra de energia ou de potência, nas condições estabelecidas pela Câmara de Comercialização de Energia Elétrica (CCEE). Adicionalmente, os agentes de distribuição deverão garantir o atendimento a cem por cento de seus mercados cativos através de contratos registrados na CCEE. Também os consumidores livres e especiais deverão garantir o atendimento a cem por cento de suas cargas de energia e potência, através de geração própria ou de contratos de compra registrados na CCEE.

\subsection{Ambientes de Contratação}

Os principais objetivos do modelo setorial são promover a modicidade tarifária e a segurança de suprimento. Como esses objetivos são conflitantes, o modelo busca atingi-los por meio da segmentação do mercado de demanda e de oferta.

Para garantir a expansão da oferta e garantir o atendimento ao consumo de energia, o governo instituiu a contratação obrigatória, antecipada e integral da carga de energia projetada dos distribuidores e segmentou o mercado de demanda em dois ambientes: o Ambiente de Contratação Regulada (ACR) e o Ambiente de Contratação Livre (ACL).

A separação da compra da energia proveniente de novos empreendimentos de geração visa resolver uma das maiores críticas ao modelo anterior (RE-SEB), qual seja sua dificuldade em viabilizar a expansão. Ainda, por meio da licitação de novos aproveitamentos com Contratos de Venda de Energia de Longo Prazo associados, também conhecidos como PPA - Power Purchase Agreement, facilita-se a obtenção de financiamento na modalidade de Project Finance ${ }^{4}$, uma vez que as garantias seriam oferecidas na forma dos recebíveis dos CCEARs assinados, com baixo risco de inadimplência, pois o montante negociado é pulverizado entre diversas distribuidoras do SIN.

As principais ações para promover a contratação eficiente de energia para os consumidores regulados seriam:

口 Proceder à compra de energia sempre por meio de leilões, na modalidade "menor tarifa";

4 O termo Project Finance define-se como uma modalidade de financiamento cujo processo de avaliação, estruturação e concessão dos recursos está calcado, primordialmente, na capacidade financeira do projeto. A decisão dos credores se baseará na capacidade do projeto em saldar suas dívidas e remunerar o capital, sem contar com os fluxos de caixa de outros empreendimentos dos acionistas (Borges e Faria, 2002). 
- Contratar energia por licitação conjunta dos distribuidores (pool), visando obter economia de escala na contratação de energia de novos empreendimentos,

- Repartir riscos e benefícios contratuais e equalizar tarifas de suprimento (realinhamento tarifário); e

- Contratar separadamente a energia de novas usinas (atendimento à expansão da demanda) e de usinas existentes, ambas por licitação.

A realização de licitações para a aquisição de energia elétrica tem por objetivo garantir transparência no processo de contratação de energia para atendimento ao mercado cativo, reduzindo o poder discricionário das distribuidoras e concorrendo para a modicidade tarifária.

Em resumo, o ACR é voltado para o suprimento de energia às distribuidoras, no atendimento aos seus mercados cativos, por meio de leilões pelo menor preço, dos quais participam quaisquer agentes vendedores. O ACL é voltado para operações de compra e venda de energia entre agentes vendedores e compradores (exceto distribuidores) através de contratos bilaterais livremente negociados entre as partes (preço, volume, período de suprimento).

\subsubsection{O Ambiente de Contratação Regulada}

Deste ambiente de contratação participam todas as distribuidoras, as quais devem atender à totalidade de seus mercados (consumidores cativos, que não atendem aos requisitos para se tornarem livres ${ }^{5}$ ou, ainda que atendam a tais requisitos, não tenham exercido esta opção). Representa, hoje, cerca de $75 \%$ do total de consumo do SIN.

Todas as aquisições de energia devem ser feitas por meio de licitações, com a realização de leilões por menor preço de energia, cujos vendedores devem assinar contratos com todas as distribuidoras participantes do leilão em questão.

Há uma segmentação do mercado das distribuidoras de forma que (i) os novos empreendimentos (energia nova) deverão ser comercializados para atender à expansão do mercado, mediante

\footnotetext{
${ }^{5}$ De acordo com a Lei $9.074 / 1995$, podem optar livremente pelo fornecedorde energia os consumidores cuja demanda seja maior ou igual a 3 MW e atendidos em nível de tensão a partir de $69 \mathrm{kV}$, se conectados antes de julho de 1995, ou em qualquer nível de tensão, se conectados após esta data. Consumidores cuja demanda seja maior ou igual a $500 \mathrm{~kW}$, em qualquer nível de tensão, também podem optar pela compra de energia a partir de fontes alternativas, de acordo com a lei 9.427/1996.
} 
licitações que se realizarão em cinco ou três anos antes da data de início de entrega da energia elétrica, por meio de contratos com duração de 15 a 35 anos; (ii) os empreendimentos existentes serão comercializados exclusivamente para atender à demanda atual, mediante contratos com duração de 1 a 15 anos em licitações realizadas com dois (A-2) ou um ano de antecedência (A-1) ou até mesmo no ano previsto para início de entrega da energia (A-0).

A ideia contida nesta segmentação é a de que a energia gerada por usinas existentes (energia "velha") e, teoricamente, já amortizadas, poderia ser comercializada por preços menores do que aquela gerada pelas novas usinas, cujos preços tenderiam ao Custo Marginal de Expansão.

Segundo a EPE os Agentes de Distribuição podem adquirir energia das seguintes formas, de acordo com o art. 13 do Decreto n ${ }^{\circ}$ 5.163/2004:

Leilões de compra de energia elétrica proveniente de empreendimentos de geração existentes e de novos empreendimentos de geração.

- Geração distribuída (conectada à rede da Distribuidora), desde que a contratação seja precedida de chamada pública realizada pelo próprio Agente de Distribuição e com montante limitado a $10 \%$ do mercado do distribuidor.

Usinas que produzem energia elétrica a partir de fontes eólicas, pequenas centrais hidrelétricas e biomassa, contratadas no Programa de Incentivo às Fontes Alternativas de Energia Elétrica - PROINFA.

$\square$ Itaipu Binacional.

- Cotas de Garantia Física e Potência ${ }^{6}$, provenientes de usinas existentes que tiveram suas concessões renovadas conforme a MP 579 de 2012, regulamentada pelo Decreto 7.805 de 2012, convertida na Lei no 12.783 de 2013.

\subsubsection{O Ambiente de Contratação Livre}

Neste ambiente podem participar todos os geradores não cotistas, comercializadores e consumidores livres, com total liberdade para negociarem seus contratos de compra e venda de energia, incluindo prazos, volumes, preços e multas rescisórias. No Brasil, a opção de migração

\footnotetext{
${ }^{6}$ Em 2012, o governo anunciou um programa, criado pela Medida Provisória 579 e regulado pelo Decreto 7.805, que trata da redução das tarifas de energia em média 20,2\% a partir de 2013 , baseado na alteração do regime de comercialização de energia das concessões de geração vencidas: rateio da energia por meio de cotas de garantia física e de potência distribuídas entre os consumidores regulados com pagamento de tarifa regulada, e na redução de encargos setoriais. (Explicação detalhada está contida no item 4.2 deste relatório).
} 
para um ambiente de contratação livre é facultativa ao consumidor, desde que este possua as características mínimas de demanda contratada e nível de tensão. Dessa forma, o encorajamento para a migração ao ACL é de cunho financeiro, ocorrendo sempre que verificada a possibilidade de economia no insumo energético para o consumidor.

No entanto, a forma de contratação de energia elétrica por parte dos Consumidores Livres não exige contratos de longo prazo, muito menos a exigência de contratar o aumento de carga com energia proveniente de novos empreendimentos.

Uma proposta para incentivar a expansão do parque gerador neste novo cenário de participação mais expressiva do mercado livre foi a permissão da cessão, a preços livremente negociados, dos montantes de energia elétrica que sejam objeto de contratos de compra e venda registrados na Câmara de Comercialização de Energia Elétrica (CCEE), garantia pela Lei 12.783 de 2013.

A motivação desta determinação decorre das súbitas, significativas e imprevisíveis mudanças que afetaram de forma irremediável e contundente o planejamento de todos os consumidores. Entre as mudanças, ressalta-se: (i) o incremento de preços (decorrente do PLD); (ii) a ampliação do prazo de retorno ao ACR por consumidores especiais de 180 dias para 5 anos; e (iii) a imprevisão sobre possível desequilíbrio entre os mercados ACL e ACR que poderia decorrer da renovação das concessões. Tal aperfeiçoamento mostra-se necessário quando do retorno para o ACR e a desistência de migração para o ACL.

Com esta flexibilidade na contratação, espera-se que os consumidores livres firmem contratos de longo prazo de forma a viabilizar novas usinas no ACL, fazendo com que este mercado passe a ter, gradativamente, um papel maior no que tange a expansão da matriz elétrica brasileira.

\section{A Evolução dos Consumidores Livres}

Apesar da liberação para se tornar Consumidor Livre atendidos os condicionantes fixados na Lei 9.074/95, em janeiro de 2001, não havia incentivos na migração para o mercado livre, fato apontado pelo Comitê de Revitalização do Setor Elétrico, que recomendou estudos com a finalidade de promover estímulos à existência de Consumidores Livres. 
Uma das recomendações deste Comitê foi a realização do Realinhamento Tarifário, iniciado entre os anos de 2002 e 2003, com o objetivo de eliminar o subsídio cruzado na componente "fio" (TUST/TUSD), existente entre classes tarifárias, até o final de 2007 (4). Segundo (4), a origem desta distorção tarifária está no fato de que ao longo da história do setor elétrico no Brasil foram criados diversos descontos concedidos sem respaldo técnico e legal, principalmente a partir da década de 70, quando teve início uma rápida expansão da indústria brasileira, incentivada, entre outras coisas, pela oferta de energia elétrica barata e abundante.

O início do realinhamento tarifário ocorreu em 2002, quando o governo federal estabeleceu que as tarifas de fornecimento de energia elétrica seriam separadas em tarifa fio e tarifa de energia, além de indicar a necessidade de revisão das mesmas, com o objetivo de promover uma tarifa mais isonômica e eficiente, de acordo com Lei $\mathrm{n}^{\circ}$ 10.604/02 e o Decreto $\mathrm{n}^{\mathrm{o}} 4.562 / 02$. Desta forma, ao final da implantação deste procedimento, a tarifa de energia deve ser um valor médio para os consumidores finais, independente do grupo. A Figura 1 demonstra que ao final do Realinhamento Tarifário os consumidores de alta tensão, mais precisamente os da classe de tensão A1, A2 e A3, terão uma tarifa de energia mais elevada, o que acabou servindo como incentivo para que os grandes consumidores de energia procurassem uma oportunidade de adquirir energia mais barata do que os valores que vinham sendo praticados pelas Distribuidoras, o que resultou no crescimento do mercado livre.

Caso o consumidor deseje retornar ao mercado cativo, ou seja, voltar a ser atendido pela distribuidora, é necessário declarar a intenção de retorno com cinco anos de antecedência, que é o prazo limite para que a distribuidora passe a atender novamente esse mesmo consumidor, segundo a Resolução Normativa 376 de 2009, podendo ser antecipado, caso haja concordância por parte da distribuidora.

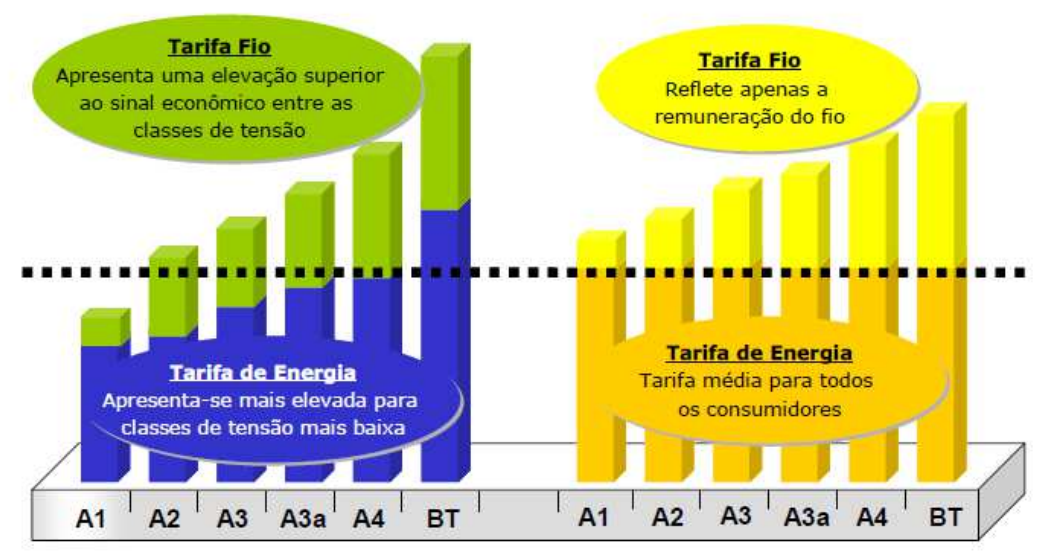

Figura 1 - Realinhamento Tarifário (Fonte:(4)) 


\subsection{Leilões de Energia}

Em se considerando " $\mathrm{A}$ " como o ano previsto para o início do suprimento de energia elétrica adquirida pelos agentes de distribuição nos leilões de energia (ano "Alvo"), o cronograma para a realização dos leilões é o seguinte:

- No quinto ano anterior ao ano "A" (chamado ano A - 5), é realizado o leilão para compra de energia de novos empreendimentos de geração;

口 No terceiro ano anterior ao ano "A" (chamado ano A - 3), é realizado o leilão para aquisição de energia de novos empreendimentos de geração;

口 No ano anterior ao ano "A" (chamado ano A - 1), é realizado o leilão para aquisição de energia de empreendimentos de Geração existentes.

A antecedência com que os leilões de energia nova ocorrem é equivalente ao tempo médio necessário para a construção do empreendimento de geração que está sendo licitado. Em geral, os leilões A-5 são para licitação de usinas hidrelétricas e, eventualmente, de térmicas convencionais de grande porte. Já os leilões A-3 são voltados para as usinas térmicas de pequeno e médio porte, PCHs e demais fontes com menor tempo de construção, tais como as eólicas e biomassa. Os leilões de fontes alternativas podem acontecer entre os anos A-1 e A-5, porém geralmente ocorrem no ano A-3, dadas as características das fontes licitadas.

A principal parcela de crescimento do mercado deve ser contratada nos leilões A-5, os leilões A-3 têm como principal objetivo atender à demanda adicional para o ano "A" que não havia sido prevista pelas distribuidoras na declaração de demanda para o leilão A-5. Do ponto de vista da distribuidora compradora, fazer uma previsão do seu mercado com três anos de antecedência é mais assertivo do que com cinco anos de antecedência, por isso haveria uma tendência natural de se concentrarem as compras de energia nos leilões A-3. Entretanto, do ponto de vista do planejamento energético, é conveniente que a maior parcela da energia nova seja adquirida nos leilões A-5, partindo-se do pressuposto de que o maior prazo de maturação dos empreendimentos, característica desse Leilão, se reflete em maior número de opções de expansão da oferta e maior competição no certame, permitindo auferir preços mais reduzidos em média do que no Leilão A-3. Por isso, são impostas condições de repasse do preço médio pago nos leilões A-3 à tarifa do consumidor final, limitando o repasse integral do preço pago no A-3 a 2\% da carga da distribuidora verificada no ano A-5. 
Ainda de acordo com o Decreto 5.163/2004, caso o montante adquirido pela distribuidora em um leilão A-3 seja superior a este percentual, o repasse do preço desse excedente fica limitado ao menor preço pago entre o A-3 e o A-5 do ano de referência.

Hoje, o critério para determinação dos vencedores de um certame restringe-se ao preço de lance, em $\mathrm{R} \$ / \mathrm{MWh}$. Tal premissa ignora fatores como o escoamento da energia, diretamente ligado ao planejamento da expansão do sistema de transmissão, e o custo real de geração para o Sistema, que engloba, por exemplo, um menor acionamento de térmicas no longo prazo e a capacidade de atendimento de carga no horário de ponta. Tais pontos geram benefícios ao sistema que não são mensurados em favor de um ou outro empreendimento ou grupo de usinas, ficando apenas o fator preço responsável pela determinação dos vencedores.

Nos Leilões de Energia Existente, os agentes de distribuição podem comprar energia de empreendimentos de geração existentes com dois ou um ano de antecedência do ano de fornecimento (chamado também de Leilão A-2 ou A-1, onde "A" é o ano de entrega da energia) ou até no próprio ano de início de entrega, em montante equivalente à reposição de contratos vincendos ou de contratos onde há previsão de redução no montante contratado para o ano seguinte.

É previsto, adicionalmente, que os agentes de distribuição possam comprar até $0,5 \%$ da sua carga verificada no ano "A-1" acima do montante de reposição, a seu exclusivo critério, bem como adquirir energia para suprir a compra frustrada em outros leilões de energia existente. A vigência dos contratos celebrados nesses leilões é de no mínimo um e no máximo quinze anos, conforme especificado em cada edital. Também são considerados como energia existente os Leilões de Ajuste, que possuem a característica de acontecerem no próprio ano de fornecimento da energia, ou seja, no ano "A", cuja duração pode ser de até dois anos e cujo montante a ser contratado está limitado a $5 \%{ }^{7}$ da carga total contratada da distribuidora no ano.

Deve-se ressaltar também a existência dos Leilões de Energia de Reserva (LER). A Energia de Reserva foi inicialmente prevista na Lei $n^{\circ} 10.848 / 2004$, e regulamentada posteriormente por meio do Decreto ${ }^{\circ}$ 6.353/2008.

\footnotetext{
${ }^{7}$ A lei faculta regular o montante limite entre $0 \%$ e $5 \%$ da carga.
} 


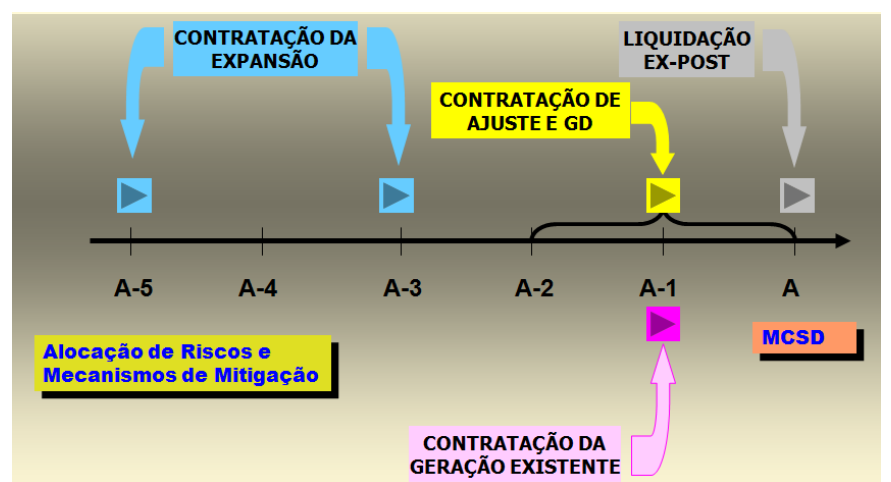

Figura 2 - Momentos de Contratação das Distribuidoras na "iinha do tempo" (Fonte: Material disciplina PEA 5916)

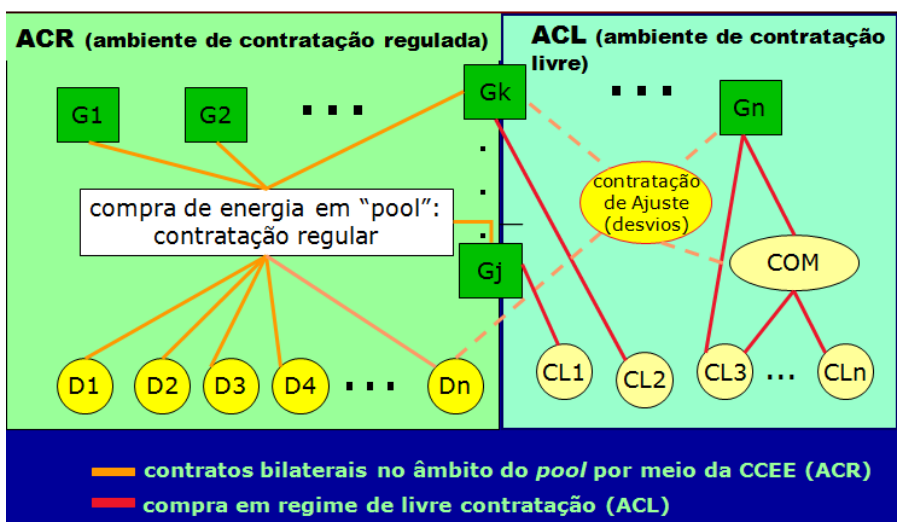

Figura 3 - Contratação de Energia Assegurada (Fonte: Material disciplina PEA 5916)

Conceitualmente, a energia de reserva não pode servir de lastro para venda para nenhum agente do SIN e deve ser contabilizada e liquidada exclusivamente no Mercado de Curto Prazo (MCP) da CCEE, não sendo objeto de contratos bilaterais, no entanto, pelos incentivos que apresenta, não deixa de ser uma alternativa a ser considerada pelos investidores.

A Resolução Normativa n ${ }^{\circ}$ 377, de 11 de novembro de 2008, determina que todos os agentes vendedores de energia de reserva devem firmar um Contrato de Energia de Reserva (CER) com a CCEE, que representa toda a integralidade do mercado consumidor, compulsoriamente envolvido no processo de aquisição. Essa energia é ressarcida através do Encargo de Energia de Reserva (EER), cobrado de todos os agentes consumidores livres, especiais e cativos (neste caso, através da concessionária de distribuição local).

A dinâmica da energia de reserva prevê que todos os vendedores recebam uma receita fixa anual, dividida em doze parcelas mensais, que é o valor resultante do montante negociado no leilão pelo preço final de venda da energia do empreendimento. 
A receita fixa deve ser suficiente para cobrir todos os custos de operação e manutenção da usina, bem como providenciar o retorno do investimento, dentro dos parâmetros estabelecidos pelo próprio empreendedor. Toda a energia gerada ao longo do ano, portanto, não pertence ao empreendedor e é liquidada no MCP ao PLD. O valor gerado por esta liquidação é retido em uma conta específica para este fim, a Conta de Energia de Reserva (CONER), administrada pela CCEE, de forma a atenuar o valor do EER pago pelos consumidores. Caso o compromisso de entrega de energia anual seja cumprido antes do final do período de apuração, a energia passa a ser do gerador. É importante destacar que a garantia física do empreendimento permanece comprometida durante toda a vigência do contrato, por isso não pode ser comprometida em contratos bilaterais sem que o empreendedor não incorra em penalidade por lastro de venda, conforme previsto nas Regras de Comercialização da CCEE.

Do ponto de vista energético, os Leilões de Energia de Reserva ajudam a mitigar a vulnerabilidade do sistema a desequilíbrios conjunturais, pois a energia advinda das usinas que venderam nesses leilões poupa a geração hidrelétrica e, consequentemente, contribui para um maior armazenamento de água nos reservatórios e entra na formação de preços, contribuindo para a redução sistemática do PLD; entretanto não compõe lastro para os agentes consumidores, de forma que não existe requisito contratual dessa energia.

Dentre as fontes de energia renováveis, a energia eólica tem sido a mais utilizada para o atendimento do crescimento da demanda, devido, principalmente, à dificuldade de viabilização das demais fontes e da disponibilidade do vento.

As primeiras negociações de energia eólica no ACR foram realizadas nos Leilões de Energia de Reserva (LER) em 2009 e nos chamados Leilões de Fontes Alternativas (LFA) em 2010. Estes são realizados em A-3, na modalidade de contratação por disponibilidade, sendo que os empreendimentos não competem com outras fontes. A especificidade dos contratos de CCEAR para eólicas inclui o repasse do risco de exposição ao comprador, além de ressarcimentos para os casos em que a geração for inferior à contratada, e limitações para os casos em que a geração for superior à contratada (o agente gerador deve garantir o fornecimento para energia nos anos de um quadriênio, para geração entre $90 \%$ a $100-140 \%$ da GF, antes de poder comercializar os eventuais excedentes anuais o mercado "spot"). 
Nos últimos leilões de energia nova esta forma de geração disputou com outras fontes já consolidadas no setor, como térmicas a gás, biomassa e PCHs, e obteve grande vantagem saindo como a grande vencedora do leilão e praticando preços inesperados para o mercado. Nos leilões realizados em 2013 (A-3, A-5 e Reserva), por exemplo, a média do índice de custo-benefício dos empreendimentos eólicos ficou na faixa dos 110 - 124 R \$/MWh, mesmo com o critério mais rigoroso de garantia física, correspondente à geração no percentil $10 \%$ da curva histórica de distribuição de ventos.

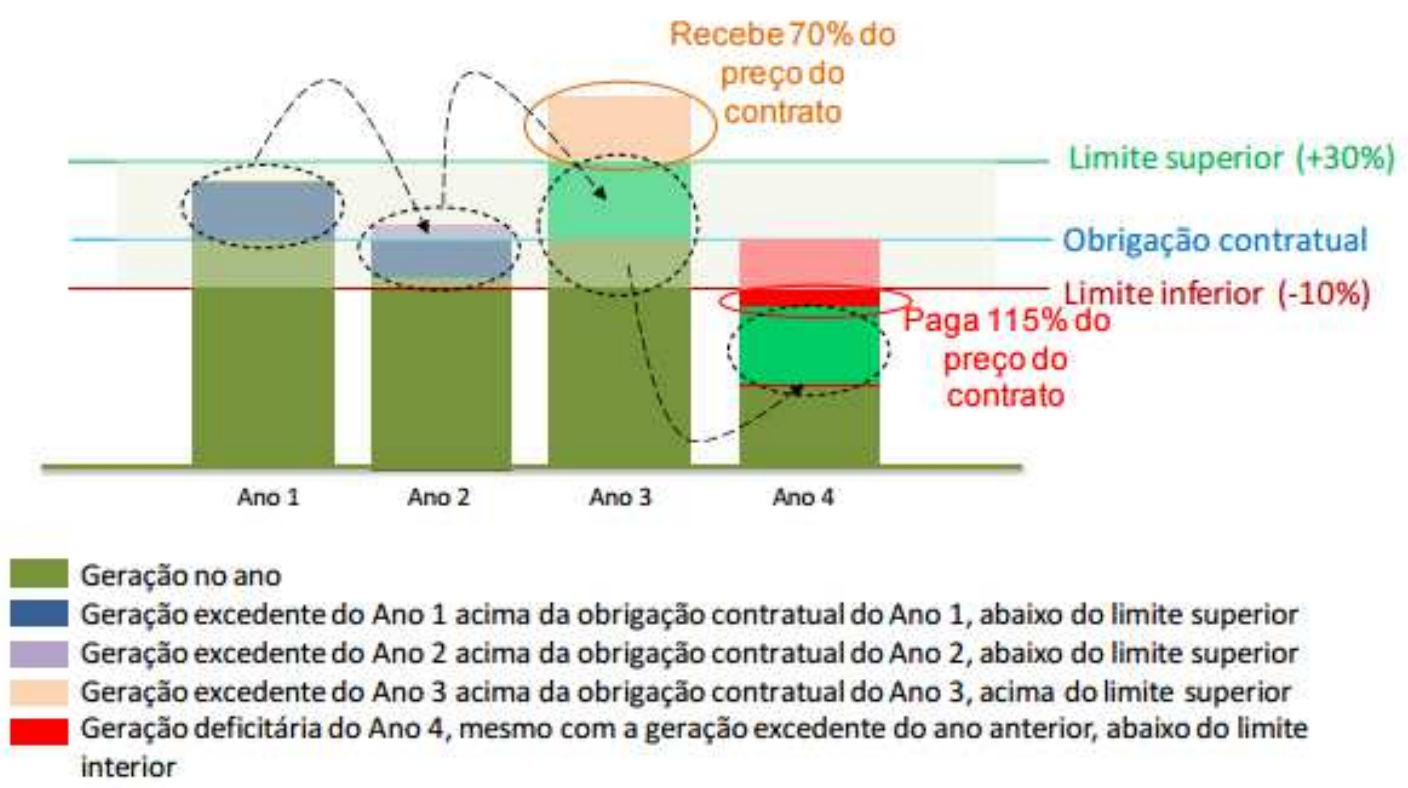

Figura 4 - Regra de Contabilização do Leilão (Fonte: Kawana 2014)

Em virtude de problemas relacionados ao atraso nos sistemas de transmissão necessários ao escoamento da energia, em especial da energia eólica resultante dos leilões onde essa fonte tem participado ativamente desde 2009, a ANEEL tem proposto a postergação do início do período de suprimento. Tal medida é questionável do ponto de vista do empreendedor, uma vez que a usina depende do recebimento da Receita Fixa para honrar com os pagamentos do empréstimo junto à financiadora do Empreendimento. Essa proposta da ANEEL é fundamentada no ônus imputado às distribuidoras, que seriam obrigadas a arcar duas vezes com os custos da energia: primeiro referente à receita fixa paga às usinas; segundo referente os custos de exposição ao PLD, uma vez que a geração dessas usinas não foi disponibilizada ao sistema devido a não existência da transmissão. Esse problema culminou em uma mudança significativa nos leilões de energia nova a partir de 2013, que passaram a utilizar como critério de classificação, além do preço do lance, a capacidade de escoamento da Rede Básica e de fronteira do local de conexão da usina. 
Para empreendimentos eólicos e/ou a biomassa tem-se na tabela a seguir um comparativo entre as opções de contratação para viabilização do projeto.

Tabela 1 - Comparativo opções de contratação (2013)

Ambiente de Contratação Regulado (ACR) $\quad$ Ambiente de Contratação Livre

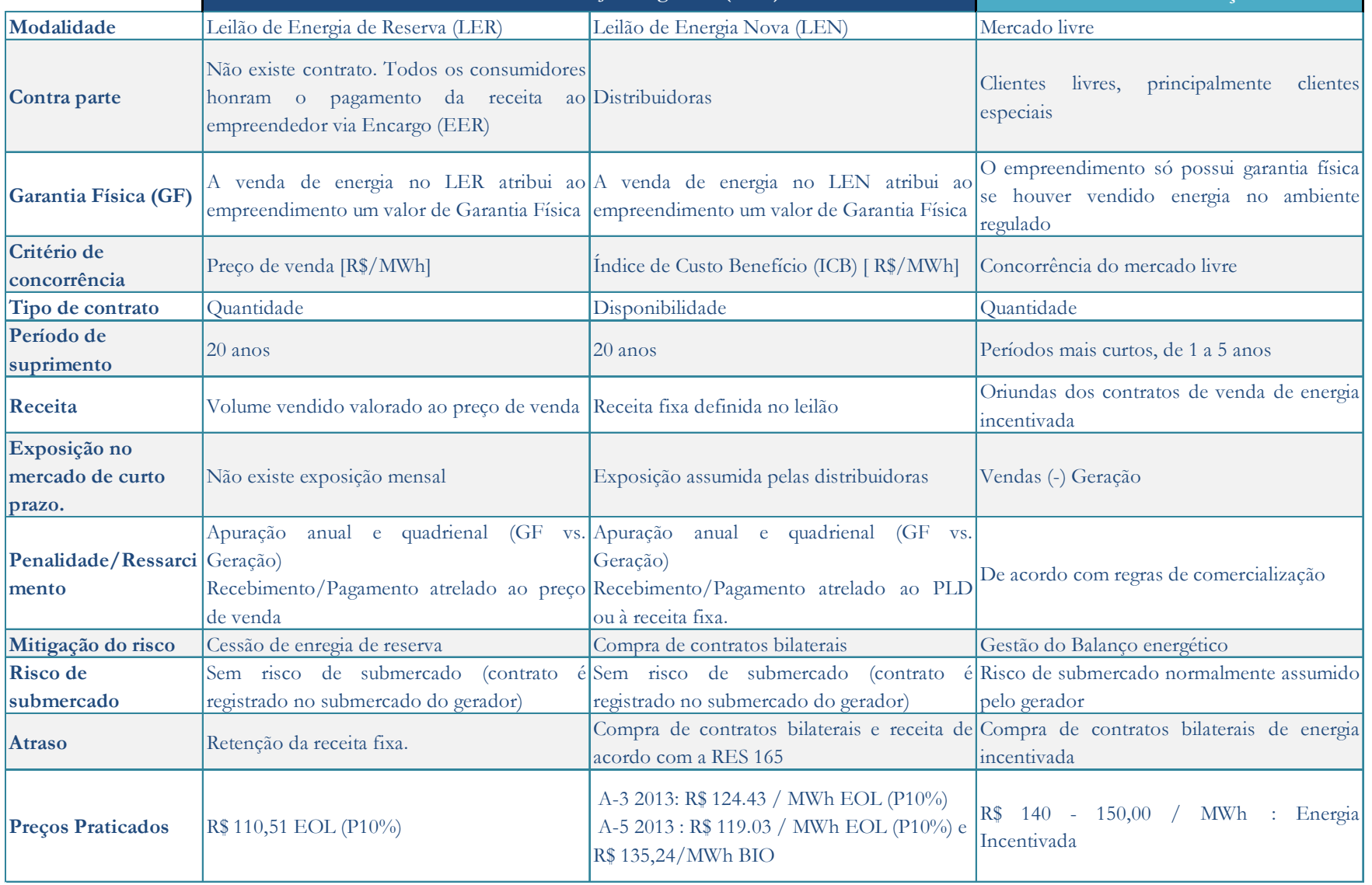

\subsection{Relações contratuais e comerciais no modelo institucional vigente no setor elétrico}

As relações comerciais entre os agentes são regidas predominantemente por contratos de compra e venda de energia, sendo que todos os contratos celebrados entre os Agentes no âmbito do Sistema Interligado Nacional devem ser registrados na CCEE, que contabiliza as diferenças entre o que foi produzido ou consumido e o que foi contratado. As diferenças positivas ou negativas são liquidadas no Mercado de Curto Prazo e valoradas ao PLD (Preço de Liquidação das Diferenças), determinado semanalmente para cada patamar de carga e para cada submercado, tendo como base o custo marginal de operação do sistema, este limitado por um preço mínimo e por um preço máximo. 


\subsubsection{A natureza do contrato de compra e venda de energia elétrica}

Tomando por base (i) os custos previstos para a construção de novas fontes de geração, (ii) o prazo necessário de entrega e (iii) a duração do contrato, como também ponderando a (iv) sinalização dos preços da energia no mercado de curto prazo - PLD, são estabelecidos os preços da energia contratada, que é negociada livremente entre consumidor e fornecedor, buscando-se um equilíbrio que pondere uma racional alocação dos riscos de variação dos preços e garanta a integridade da saúde financeira tanto de fornecedores como dos consumidores.

Neste ambiente, os contratos constituem um interessante mecanismo para garantir uma renda fixa aos fornecedores, caracterizando-se também como uma forma de proteção, para os consumidores, contra elevações bruscas nos valores do PLD e garantem também maior clareza para seus custos, já que garantem um fluxo de caixa constante e previsível sob o prisma da aquisição do importante insumo caracterizado pela energia elétrica.

Quanto maior for o período de contratação, menos expostos a essas variações os consumidores estarão, porém estes perdem a oportunidade de receber energia a preços baixíssimos quando houver grande disponibilidade energética.

$\mathrm{Na}$ ótica oposta, pelo lado dos agentes vendedores, haveria interesse em estabelecer contratos de longo prazo para se "defender" das consequências financeiras que decorreriam da venda sistemática no mercado de curto prazo (liquidando a produção ao PLD ou então firmando apenas contratos de curto prazo). Entretanto, a decisão de vender todo o montante de sua Garantia Física em contratos de longo prazo pode implicar na necessidade de adquirir, no mercado de curto prazo, montantes de complementação importantes, em situações em que a geração for inferior à Energia Assegurada do gerador.

Essas situações são características de uma condição energética extremamente desfavorável para o sistema, com ocorrência de vazões muito aquém da média de longo termo (MLT) ou então reservatórios deplecionados ao extremo. Como consequência, em tais situações ocorre elevação significativa do PLD e dado que um episódio hidrológico desfavorável pode perdurar vários meses, os riscos de insolvência financeira para os agentes expostos podem se tornar insuportáveis. Para se defender dessas ocorrências, os agentes geradores hidráulicos frequentemente renunciam à possibilidade de comercializar toda a sua placa em contratos de 
longo prazo, o que garantiria a maximização de sua expectativa de receita em longo prazo, deixando uma margem da sua Energia Assegurada propositadamente descontratada e assimilando as perdas decorrentes de liquidar parte de sua energia a preço baixo na maior parte do tempo.

No caso de uma usina térmica, este risco é relativamente pequeno, pois nos períodos de preço de curto prazo elevado a planta estará gerando em sua capacidade máxima e, portanto, atendendo a seu contrato. No caso de uma hidrelétrica, entretanto, este risco é substancial, pois os períodos de preços de curto prazo elevados são justamente os de seca severa, onde sua produção diminui.

No caso de plantas eólicas e a biomassa, a exposição ao mercado de curto prazo, sempre que sua geração for inferior ao montante contratado, pode ocorrer em um momento de preços spot elevados, culminando nos riscos de insolvência mencionados acima.

\subsubsection{Características de um contrato de energia}

Um contrato de compra e venda de energia elétrica é caracterizado por três variáveis básicas:

Preço: valor, em R $\$ / M W h$, da energia comercializada;

Prazo: duração do contrato;

Volume: quantidade de energia a ser comercializada, em MWh, potência associada, em MW, e requisitos de flexibilidade, sazonalidade e modulação.

Adicionalmente, outras características são importantes na formação do preço e avaliação dos riscos do negócio:

- Início de suprimento: data de início da entrega de energia. É um parâmetro importante, pois define a proximidade entre a data de fechamento do contrato e a de entrega efetiva de energia, com os riscos e incertezas inerentes a esta distância, impactando de forma significativa no preço do contrato;

- Ponto de entrega: local de entrega da energia, podendo ser na barra da geração, no centro de gravidade ${ }^{8}$ do submercado da geração, no centro de gravidade do submercado da carga ou na barra da carga. Sua importância na formação do preço da energia é relevante à medida que define a quem caberá a cobertura das perdas elétricas (também

\footnotetext{
${ }^{8}$ Centro de Gravidade é um ponto fictício do sistema, que não necessariamente corresponde a uma barra física, definido de tal forma que as perdas elétricas causadas por geradores e consumidores sejam igualmente divididas.
} 
conhecidas como perdas técnicas) decorrentes do negócio, bem como qual parte estará exposta a eventuais diferenças de preços entre submercados.

\subsubsection{Modalidades de contratação}

São modalidades de contratos:

Contrato de Disponibilidade - São contratos nos quais tanto os riscos, como o ônus e os benefícios da variação de produção em relação à energia assegurada são alocados às Distribuidoras e repassados aos consumidores regulados.

Contrato de Quantidade - Os riscos de geração são assumidos totalmente pelos geradores, cabendo a estes todos os custos referentes ao fornecimento da energia contratada.

Em um contrato por disponibilidade, onde a contraparte é uma usina térmica com CVU, a parcela de receita referente ao custo esperado com geração não faz parte da receita fixa do contrato, pois assume-se o pressuposto de que, ao longo do ano, na maior parte do tempo o atendimento à carga seja feito através de energia mais barata, como a fornecida pelas hidrelétricas e nucleares, por exemplo.

Apenas quando uma usina térmica convencional é chamada a gerar, ou seja, é despachada pelo Operador Nacional do Sistema Elétrico (ONS), é que o comprador paga ao vendedor responsável por esta usina a parcela de receita variável, que contempla o CVU dessa usina. Em contrapartida, em um contrato por disponibilidade no qual a usina envolvida é uma biomassa sem CVU, é esperado que esta usina entregue uma quantidade de energia anual, porém as aferições desse montante não são realizadas em base mensal como nos contratos por quantidade, mas sim em base anual. A receita fixa, neste caso, já contempla essa geração e não há parcela variável associada a esta modalidade de contratação (5).

O conceito de contrato por quantidade utilizado para as térmicas sem CVU foi estendido para as usinas eólicas que negociam energia nos leilões de energia nova. Apesar de existir um compromisso de entrega de energia, este é apurado em base anual, portanto, os riscos decorrentes da variação mensal de geração versus o compromisso contratual são assumidos pela parte compradora. 
Tanto os contratos do ACR como os do ACL são registrados na CCEE e servem de base para contabilizar e liquidar as diferenças no mercado de curto prazo. Os montantes totais contratados são liquidados bilateralmente pelos Agentes, fora do ambiente de operações da CCEE e de acordo com condições contratuais específicas.

\subsubsection{Contratos de leilões de energia nova (LEN)}

Nos contratos de energia nova provenientes dos leilões A-5, A-3 e de Fontes Alternativas (LFA), todos os empreendimentos possuem lastro dado através da garantia física definida pelo MME. No caso dos contratos por disponibilidade, a sazonalização é "flat" e as diferenças mensais apuradas são assumidas pelas Distribuidoras. O faturamento das usinas é fixo, equivalente a 1/12 do valor do contrato anual. Para as renováveis não convencionais, a denominação “disponibilidade" não exime o empreendimento de uma entrega anual de energia.

Para energia de fonte eólica, a usina deve entregar às Distribuidoras a totalidade da energia correspondente à garantia física associada ao contrato. Em caso de atraso ou descasamento da entrada em operação comercial das unidades geradoras em relação ao início de suprimento do CCEAR motivados pelo vendedor, este deverá recompor o lastro de acordo com as premissas estabelecidas pela REN 165/2005.

Até os leilões ocorridos em 2012, o atraso da entrada em operação comercial das instalações de distribuição e transmissão, necessárias para o escoamento da energia produzida pela usina, não eximia o comprador do pagamento da Receita Fixa, desde que este estivesse apto a operar comercialmente. Nesse caso, o atraso não caracterizava insuficiência de lastro para atendimento do contrato e, por essa razão, não havia necessidade de compra de contrato bilateral para suprir a não entrega de energia. De acordo com tais premissas, as consequências, portanto, seriam absorvidas pelas Distribuidoras, que, além de pagarem a Receita Fixa, ficariam expostas negativamente ao PLD, resultando em um aumento da tarifa cobrada do consumidor final.

Essa realidade mudou a partir do LER de 2013, onde a capacidade de escoamento da energia tornou-se um fator determinante para a negociação no leilão. Os próximos leilões que se seguiram, A-3 e A-5 de 2013, não previam em seus contratos o recebimento de receita fixa em caso de atrasos não imputáveis ao vendedor. Dessa forma, a conexão agora fica por conta e risco dos empreendedores e, caso o sistema de transmissão de demais instalações não caminhe 
conforme o planejamento e não haja linhas, subestações ou ICGs necessárias ao escoamento, o agente vendedor deverá recompor o lastro da distribuidora através da compra de contratos bilaterais.

No caso da usina de fonte eólica, o montante compreendido entre o limite mínimo e máximo de cada ano do quadriênio é apurado no ano seguinte, cumulativamente. O limite máximo é de 30\% do total negociado para o primeiro ano de cada quadriênio, $20 \%$ para o segundo, $10 \%$ para o terceiro e $0 \%$ para o quarto. Portanto, ao final de cada quadriênio, a geração acima do montante contratado é valorada diretamente ao PLD médio anual, não podendo ser utilizada como lastro para o quadriênio seguinte.

\subsubsection{Contratos de energia reserva}

A dinâmica de apuração do compromisso com o CER para fonte eólica prevê a subdivisão do prazo de suprimento de 20 anos em cinco períodos de conciliação quadrienal para efeitos de contabilização e liquidação de diferenças. A produção média anual (e não mensal, como ocorre nas outras fontes convencionais) é comparada com a obrigação contratual, obtendo-se o saldo de cada ano. Com base no saldo anual, tem-se o seguinte encontro de contas dentro do quadriênio:

- Se o saldo anual for inferior a 90\% da obrigação contratual, o vendedor de energia deve ressarcir à CCEE o montante de energia não entregue, até o limite inferior, no preço do contrato acrescido de $15 \%$, em 12 parcelas;

- Se o saldo anual for superior a $130 \%$ da obrigação contratual, o vendedor de energia receberá da CCEE o montante de energia entregue, até o limite superior, a 70\% do preço do contrato, em 12 parcelas;

- Se o saldo anual estiver entre $90 \%$ e 130\% da obrigação contratual, não haverá encontro de contas, e o saldo é carregado para o ano seguinte.

Ao final de cada quadriênio é realizado um encontro final de contas:

- Energia gerada entre $90 \%$ e $100 \%$ : pagamento de penalidade pelo valor do contrato;

○ Energia gerada entre $100 \%$ e $130 \%$ : (i) utiliza a diferença como crédito para o próximo período ou; (ii) recebimento pelo valor do contrato ou; (iii) transfere a diferença para outro parque através de cessão;

- Até o $4^{\circ}$ LER, ocorrido em 2012, quando o critério para cálculo de garantia física das eólicas era o P50, era prevista a revisão do montante contratado para o próximo 
quadriênio quando da ocorrência de geração de energia ao longo do quadriênio inferior à contratada.

Em resumo, a tolerância estabelecida dentro de uma banda, que fica entre $90 \%$ e $130 \%$ da quantidade contratada, permite a previsibilidade do fluxo de recursos por parte do investidor. $\mathrm{O}$ gerador, num ano em que houve pouco vento, poderá compensar a baixa geração de energia no ano seguinte, sem impacto na receita fixa, dentro de um quadriênio.

No caso da biomassa, não há apuração quadrienal. O compromisso de entrega de energia é anual e, caso o montante gerado fique entre $90 \%$ e $100 \%$ do compromisso contratual, o valor deve ser ressarcido à CONER ao preço de venda. Caso a geração anual fique abaixo de $90 \%$ do compromisso, é prevista uma penalidade de 15\% sobre o preço de venda no ressarcimento. Em contrapartida, as Regras da CCEE, de acordo com as premissas do CER, preveem a liberação da energia gerada a partir do momento em que o compromisso de com o leilão é atingido. A geração é então valorada ao PLD e o saldo financeiro passa a ser do agente vendedor e não mais da CONER. Vale ressaltar que o lastro referente a essa energia não é liberado, ou seja, a energia não será passível de alocação em contratos bilaterais, mas apenas valorada no mercado Spot.

De maneira geral, o Novo Modelo do Setor Elétrico foi concebido pretendendo atender a preocupação de estabelecer um marco regulatório estável de forma a atrair investimentos na expansão do sistema de geração, garantir níveis confiáveis de suprimento e proporcionar modicidade tarifária.

A expansão do sistema de geração e a garantia do suprimento são suportadas pelo binômio planejamento/contratação. No que se refere ao planejamento, o Modelo implantado em 2004 obriga parte dos agentes de consumo (distribuidores) a preverem suas necessidades para um horizonte relativamente longo, de cinco anos.

Estas previsões servem para sinalizar a necessidade de construção de usinas, em tempo hábil para que estes empreendimentos possam ser licitados e construídos. Os agentes de geração vencedores destes processos de licitação ganham, além do direito de explorar comercialmente o empreendimento que construirão, contratos de longo prazo (mínimo de quinze anos) de venda de energia, celebrados com os agentes de distribuição. 
A modicidade tarifária é proporcionada pela forma de aquisição de energia dos agentes de distribuição, através de leilões que buscam o atendimento das necessidades de contratação pelo menor preço possível, resultante de competição entre os agentes vendedores.

Tal modelo vem apresentando constantes atualizações ao longo dos anos, sendo que o modelo atual apresenta formas de sinalizar e induzir a expansão do parque gerador, em estreito alinhamento à previsão de crescimento por parte dos distribuidores. No entanto, o grande desafio é o incentivo à contratação de longo prazo por parte dos Agentes do Mercado Livre, de forma a mitigar o risco de abastecimento do mercado com a confiabilidade requerida, posto que os contratos de longo prazo são fundamentais para alavancar os financiamentos imprescindíveis ao desenvolvimento de novos projetos de geração focados no ACL.

Em resumo, há diversas críticas sobre o funcionamento do modelo de contratação, que se aponta como incompleto, em face da lacuna de não exigência de lastro de longo prazo para os Grandes Consumidores. Não obstante, somente o tempo mostrará se o modelo de expansão é sustentável sem novos ajustes, ou se ainda necessita aprimoramentos que lhe proporcionem a robustez necessária.

\subsection{O mercado de curto prazo e o regime de complementação térmica}

Como a energia elétrica tem a característica de não ser armazenável em grandes quantidades e de forma economicamente viável após ter sido gerada, o balanço produção-consumo deve ser feito instantaneamente, de forma que pode haver diferenças entre o volume contratado e o consumido. Essa diferença deve ser liquidada no mercado de curto prazo, valorado a um preço que reflita o custo marginal de operação do sistema.

O custo marginal de operação do sistema elétrico é, de forma simplificada, dado pela usina térmica mais cara despachada por motivos energéticos ou pelo valor da água naquele instante. É obtido através da utilização de uma cadeia de aplicativos de otimização do sistema (Newave e Decomp, desenvolvidos pelo CEPEL).

Nessa perspectiva, o objetivo do Mercado de Curto Prazo é a contabilização e a liquidação de diferenças entre os montantes de energia contratados e os efetivamente consumidos ou produzidos pelos agentes. Esta atividade é realizada mensalmente, tendo como base o Preço de 
Liquidação de Diferenças - PLD - que é publicado antecipadamente pela CCEE, calculado semanalmente para cada patamar de carga, utilizando os mesmos modelos adotados pelo ONS para programação e despacho da geração do sistema, com as adaptações e restrições necessárias para refletir a formação dos preços.

$\mathrm{Na}$ prática, são feitas basicamente duas alterações nos dados de entrada utilizados pela CCEE em relação àqueles utilizados pelo ONS. Primeiramente, a CCEE retira geração das unidades geradoras que se encontram em fase de teste; em seguida, a CCEE desconsidera as restrições internas a cada submercado, de maneira a considerar a energia igualmente disponível em todos os pontos de consumo de carga de cada submercado. Finalmente, são estabelecidos anualmente pela ANEEL valores máximos e mínimos de PLD, diferentemente do CMO, o qual pode variar de zero (quando há vertimento) até o custo da térmica mais cara disponível (6).

O cálculo do preço baseia-se em informações previstas, anteriores à operação real do sistema, considerando-se os valores de disponibilidades declaradas de geração e o consumo previsto de cada submercado, por isso, denominado "ex-ante". Para o controle de despacho energético, pelo modelo NEWAVE, são utilizadas as séries hidrológicas anuais do histórico de vazões, em conjunto com os dados do parque gerador brasileiro e as projeções de demanda de energia elétrica no país, ao longo do horizonte de estudo, de forma a dar as diretrizes para o despacho ótimo da capacidade de produção de energia elétrica.

Conhecendo-se o comportamento estocástico das afluências, através do estudo das séries históricas, é possível acompanhar a evolução do sistema para o período desejado para inúmeras hipóteses de afluências. Partindo de um determinado nível de armazenamento, em cada uma das hipóteses o sistema seguirá uma trajetória distinta, que gerará um custo futuro. A média dos custos futuros de todas as trajetórias sorteadas será o custo futuro médio.

O método de Programação Dinâmica Estocástica permite trazer informações do futuro para o presente, através do estudo da evolução do sistema, a partir de cada nível de armazenamento, denominado Estado, para cada intervalo de tempo, denominado Etapa. Adicionalmente, esse método também garante que em cada uma das trajetórias, o custo futuro seja o mínimo e, dessa forma, a média desses custos garante que o custo futuro calculado é o ótimo. 
Desta forma, o modelo avalia em base científica a solução de compromisso entre uma condição de armazenamento no sistema e uma tendência hidrológica, comparando as opções de despachos térmicos no presente, preservando a água nos reservatórios, versus não gerar termelétricas e utilizar a água que poderia substituir o despacho de térmicas caras e racionamento futuro. A solução ótima para o problema de programação de um sistema hidrotérmico é estabelecer o balanço entre o benefício do uso imediato da água e o benefício futuro de armazená-la. Este benefício é mensurado em termos de expectativa de economia de combustível do deslocamento da geração térmica, ou ainda pelo custo evitado de racionamento.

Para o sistema brasileiro, entretanto, devido à existência de diversos reservatórios, este método encontra uma barreira na sua dimensionalidade, ou seja, o número de estados cresce exponencialmente a cada reservatório incrementado ao problema, o que impede que seja usado em sistemas que precisem operar diversos reservatórios. Por isso, foi adotada a técnica de Programação Dinâmica Dual Estocástica (PDDE), que consiste no cálculo da Função de Custo Futuro para apenas alguns estados. O número reduzido de estados é compensado pelo cálculo da taxa de variação do custo futuro em sua vizinhança, chamada de derivada do custo futuro, calculada pelo método de linearização por partes ${ }^{9}$. Os estados para os quais serão traçadas as trajetórias de custo futuro são selecionados através de simulações que utilizam sequências de afluências sorteadas, a partir da distribuição estatística dos dados. Assim, na PDDE, o estado não considera apenas o nível de armazenamento, mas também o comportamento da afluência anterior, dado seu comportamento autorregressivo, onde afluências futuras dependem de afluência passadas.

Para cada estudo de caso ou rodada no Newave, é possível escolher detalhes acerca do tipo de execução que se deseja realizar como, por exemplo, período estático inicial, período de planejamento, volume inicial dos reservatórios equivalentes, tendência hidrológica, entre outros. Um dos parâmetros que também pode ser escolhido e que é fundamental para esta etapa do estudo é o Tipo de Simulação Final (7). Dentre os quatro tipos possíveis, os mais comumente utilizados são a simulação final com séries sintéticas e a simulação com séries históricas. Através do estudo de afluências históricas conhecidas e consolidadas desde 1931, que fornecem o comportamento estatístico das vazões, foi possível o desenvolvimento pelo CEPEL de um modelo estatístico que se ajustasse ao comportamento de tais séries, para a "construção" de séries sintéticas.

\footnotetext{
9 A simplificação no cálculo da derivada da Função de Custo Futuro pelo método de linearização por partes distorce o cálculo do custo marginal de operação efetivo, representando melhor os custos médios.
} 
Nesse modelo, denominado "Autorregressivo Periódico de Ordem P", ou simplesmente "PAR (p)", as afluências esperadas dependem de afluências passadas que ocorreram em até "p" meses anteriores, para aquela mesma localidade. A dependência temporal das afluências assumida na modelagem adotada no Newave é inconsistente, do que decorre que o método utilizado, baseado no modelo "PAR (p)", é questionável.

Tomando como referência o horizonte de planejamento, a otimização da operação do sistema se dará quando houver a minimização de seu custo em todo o horizonte de estudo. Por se tratar de um sistema hidrotérmico com grande participação da fonte hidráulica e por consequência com forte dependência das afluências que tem natureza estocástica, a decisão fica mais complicada, pois o sistema tem memória e uma decisão de gerar energia agora utilizando mais água pode acarretar em um maior despacho de termelétricas no futuro, aumentando o custo de operação do período. Portanto, o problema de otimização deve considerar a operação do sistema de imediato e as consequências desta operação no futuro.

Não obstante, esta decisão sofre a limitação de confiabilidade imposta ao sistema, sendo estes parâmetros conflitantes, ou seja, para assegurar custos baixos o indicado seria fazer uso apenas da geração hidrelétrica, porém esta política é pouco confiável, pois leva a altos índices de riscos de racionamento a longo prazo. Por outro lado, a confiabilidade seria substancialmente elevada se a termeletricidade operasse na base da geração do sistema com a manutenção dos altos níveis dos reservatórios, entretanto os custos de geração seriam elevados.

É com base nessas premissas, analisando a condição presente e a previsão da situação futura, considerando geração hidrelétrica, térmica e a transferência de energia entre regiões, que o ONS elabora o Planejamento da Operação do Sistema Interligado Nacional. Cumpre destacar, que este planejamento não é tão simples de se efetivar, haja vista que os dados futuros são associados ao período de cinco anos à frente e são obtidos com base em dados simulados. Portanto o fator incerteza é condicionante nesse horizonte de planejamento. 


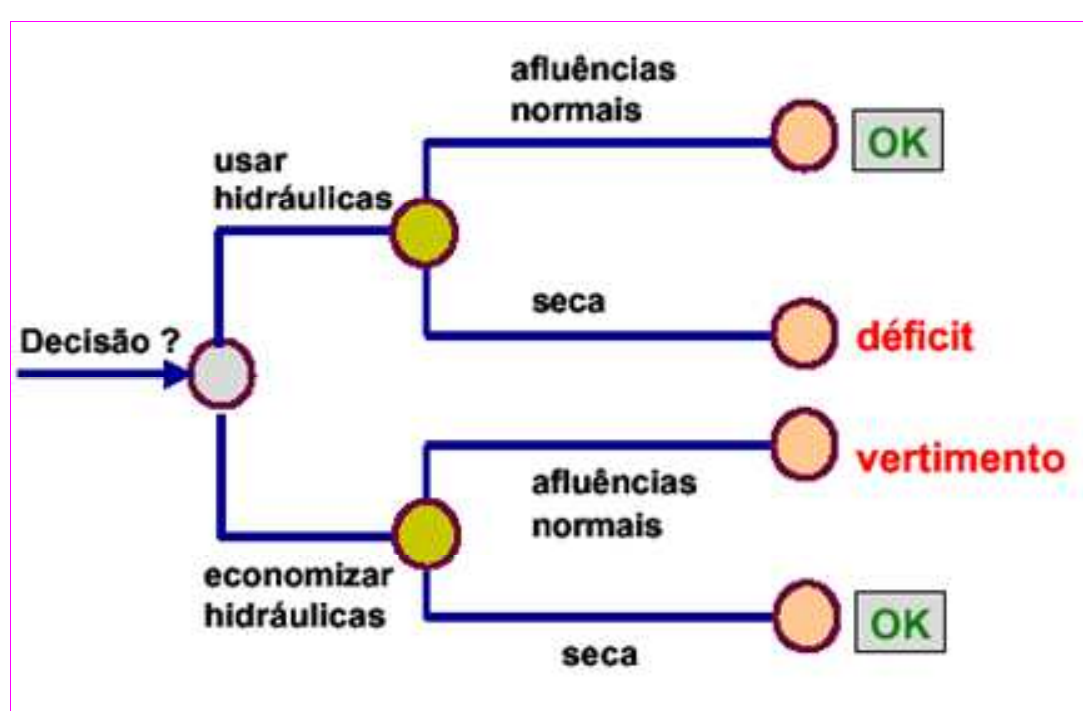

Figura 5 - Decisão Hidro-térmica (Fonte: Material disciplina PEA 5917)

Um regime de complementação térmica em um sistema predominantemente hidroelétrico é compreendido como o modo de operação do parque termoelétrico que permite a máxima eficiência possível no aproveitamento energético dos recursos disponíveis para o abastecimento atual e futuro do sistema. Assim, devido à sazonalidade das afluências hidricas, o que causa variação na energia produzida ao longo do tempo, o parque hidroelétrico é dimensionado para garantir o atendimento da demanda em condições hidrológicas críticas, conferindo-lhe uma capacidade de produção de energia adicional quando a hidrologia é mais favorável, permitindo, a custo nulo, um aproveitamento desta energia adicional sem a necessidade de despacho térmico.

Assim, o papel das térmicas na matriz energética brasileira é o de proporcionar uma espécie de "seguro" para a ocorrência de hidrologias adversas, operando em complementação térmica, de forma a permitir a operação ótima do sistema no suprimento confiável da carga prevista, em períodos de baixas afluências, ou ainda como complementação da potência em horários de ponta, aumentando a capacidade de suprimento de energia garantida do sistema.

Supõe-se agora um sistema com uma parcela representativa de plantas eólicas. Estas não possuem reservatório de armazenamento e regularização, possuindo um custo de manutenção baixo e nenhum custo de combustível. Pode se dizer, portanto, que tais usinas seriam tratadas como térmicas com custo de operação nulo. Assim sendo, todas as unidades eólicas seriam despachadas na base, respeitando a disponibilidade média mensal do recurso (vento), que é variável ao longo do ano e depende da região onde estão implantadas. 
Para haver complementação com usinas hidrelétricas deve-se ter produção de energia por parte das eólicas em períodos de baixa vazão afluente, situações em que a os reservatórios hidráulicos serão poupados.

O maior problema é como modelar as fontes de geração sazonal e intermitente, de forma a determinar a geração esperada de cada uma, em especial as PCHs e as Eólicas, dada a estocacidade da geração associada a essas fontes.

O próprio conceito de energia de reserva existe no sentido de que a geração das fontes negociadas nesses leilões poupa a geração das grandes hidrelétricas e, consequentemente, poupa a água dos reservatórios para que esta possa ser utilizada em despachos futuros. Embora o termo reserva possa sugerir energia a ser disponibilizada em situações restritivas de abastecimento do sistema, o que ocorre na prática é a utilização prioritária e contínua da energia de reserva, em detrimento da geração despachável (hidrelétricas e termelétricas com CVU diferente de zero).

O estudo de Marzano (2009) elaborado a partir do cenário de referência do Plano Decenal de Expansão de Energia (PDE 2007-2016) fez avaliações energéticas dinâmicas e estáticas do impacto da substituição gradativa de usinas térmicas a gás natural e óleo diesel no Nordeste e Sudeste, por usinas eólicas no Nordeste e Sul, abordando aspectos como: benefícios ao SIN, complementaridade entre os regimes hidrológico e eólico, impactos no Custo Marginal de Operação - CMO, impactos na Geração Hidráulica e Energia Armazenada.

Para a região Sudeste/Centro-Oeste os resultados das simulações mostraram que ocorre uma redução da geração hidráulica no período seco à medida que a participação da energia eólica torna-se mais efetiva. Ainda nessa contexto, quando se tratou da Energia Armazenada observouse que na medida em que a participação eólica torna-se mais efetiva, maior se torna a Energia Armazenada do sistema.

O estudo de Ramos e Matos para a APINE (Associação Brasileira dos Produtores Independentes de Energia Elétrica) (11) visou a avaliação do impacto da participação da Geração Eólica no Mecanismo de Realocação de Energia contemplando reconstituição de séries temporais de velocidade de vento. A análise buscou avaliar os impactos que a geração eólica teria no MRE quando são consideradas as incertezas associadas à intensidade de ventos. 
Apesar da configuração eólica e metodologia de cálculo da Garantia Física não refletirem diretamente a condição atual do SEB, é possível verificar alguns aspectos: a participação das Eólicas pode ser muito interessante para o MRE, mas depende da relação entre contribuição de geração e Garantia Física; como todo o MRE foi modelado com perfil de sazonalização "flat", isso contribui para que as eólicas proporcionem um impacto positivo no período de CMO mais elevado, isto porque acrescentam energia quando as hídricas enfrentam um período de estiagem.

Existe hoje uma concentração de tipos específicos de fontes em algumas regiões do país, o que confere uma parcela significativa de incerteza à energia disponível, pois um evento atmosférico ou climático adverso locacional pode comprometer a oferta energética da região, exigindo manobras de cunho emergencial e sobrecarregando os sistemas de transmissão, podendo ocasionar custos adicionais ao sistema. Dessa forma, não apenas a complementaridade entre regiões, mas também a possibilidade de diversificação dentro do mesmo submercado e entre regiões vizinhas, podem trazer ganhos energéticos para os sistemas e, consequentemente, financeiros à operação.

\subsection{Processo de contabilização e liquidação financeira}

Conforme premissas estabelecidas no Decreto 5.163/2004, todos os agentes devem apresentar lastro para cobertura de 100\% de suas transações comerciais dentro do SIN. Para realização da contabilização, a CCEE precisa de três informações básicas: dados de medição de todos os agentes em base horária (geração e consumo), dados dos contratos firmados (ACL e ACR, com contrapartes, volumes e vigência) e o PLD. Para cada período de comercialização, o sistema apura as diferenças entre a energia verificada e a energia contratada e valora essas diferenças ao PLD no mercado de curto prazo ou Spot. Quando se trata de fontes como a biomassa e a eólica os valores de energia verificada podem variar significativamente entre as horas do dia e os meses, no caso das eólicas, e entre os meses, no caso da biomassa (resultado do período de safra). Esse comportamento pode acarretar em grandes diferenças, positivas ou negativas, em relação ao montante contratado, uma vez que a maioria dos contratos é do tipo "flat" (mesma quantidade MWmed alocada a todos os meses). Soma-se a isso a grande instabilidade do preço que valora essas diferenças, o PLD. Dessa forma, mesmo que no longo prazo as diferenças positivas compensem as negativas, grandes exposições valoradas a PLDs extremos podem gerar um efeito insustentável no caixa das empresas, por isso devem ser evitadas. 
Não apenas as exposições ao Spot constituem o processo de contabilização da CCEE, mas sim um conjunto de deveres e obrigações traduzidos nas Regras e Procedimentos de Comercialização, tais como penalidades, encargos, apuração de garantia física, MRE, entre outros.

A liquidação financeira da CCEE é um processo multilateral, não sendo identificadas as contrapartes no processo. A posição credora ou devedora de um agente, resultante do processo de contabilização, é tida em relação ao mercado e não a um determinado agente. A liquidação financeira das relações contratuais pactuadas entre os agentes são realizadas diretamente entre as partes, não havendo participação da CCEE.

Uma vez que o processo de liquidação da CCEE é multilateral e os débitos são utilizados para compensar os créditos, uma eventual inadimplência é refletida para todo o mercado credor. Por isso, a constituição de garantias financeiras deve ser efetuada mensalmente pela CCEE, com base na análise da exposição de cada agente no mercado de curto prazo. O aporte de garantias financeiras é uma obrigação do agente da CCEE, e seu descumprimento acarreta multa e pode ser motivador de desligamento do agente da Câmara. 


\section{AJUSTES NO MODELO DE COMERCIALIZAÇÃO}

\subsection{Comercialização de Energia Incentivada}

\subsubsection{Preâmbulo: Programa de Incentivos às Fontes Alternativas de Energia Elétrica - PROINFA}

Apesar da oportunidade de migração, o mercado livre não vinha apresentando interesse por parte dos consumidores, pois, até meados de 2002, o número de consumidores livres não era expressivo. Nesse contexto, o mercado de Consumidores Livres ${ }^{10}$ ainda não dava os sinais econômicos adequados para expansão das fontes alternativas.

Além disso, nos últimos anos surgiu uma tendência mundial de buscar fontes de energia mais limpas e renováveis, demonstrando a preocupação de diversos setores da sociedade com os impactos ambientais envolvendo questões como emissão de gases do efeito estufa, aquecimento global e inundações de vastas áreas para construção de barragens.

Neste sentido, em 2002, o governo federal criou o Programa de Incentivo às Fontes Alternativas - PROINFA, com o objetivo de aumentar a participação da energia elétrica produzida por empreendimentos das fontes alternativas de energia elétrica, por meio de subsídios a Produtores Independentes de fontes economicamente não competitivas com o mercado vigente à época. Esse programa foi instituído a partir de 2002, por meio da Lei no 10.438.

Todos os contratos de compra e venda de energia do PROINFA são representados pela Eletrobrás, que vende a energia das fontes alternativas de acordo com a cota-parte de cada carga do SIN. Esses contratos são compulsórios a todas as cargas e remunerados via Tarifa de Uso do Sistema de Distribuição e/ou Transmissão e têm duração de 20 anos.

Inicialmente a meta era instalar 3.300 MW, igualmente distribuídos entre empreendimentos que gerem energia a partir de biomassa, energia eólica ou PCH, porém com o passar do tempo diminuiu o interesse por parte das usinas de açúcar e álcool.

\footnotetext{
${ }^{10}$ Unidades consumidoras com demanda contratada superior a $500 \mathrm{~kW}$ podiam migrar para o ambiente livre, desde que comprasse energia proveniente de fonte alternativa.
} 
Hoje em dia, há mecanismos mais eficientes, do ponto de vista do Consumidor, para alavancar projetos de energia renovável, pelo que o PROINFA foi descontinuado pelo Governo.

\subsubsection{O Modelo de Comercialização de Energia Incentivada}

O crescimento do mercado consumidor, a diminuição do interesse das usinas a biomassa em participar do PROINFA e a não concretização do previsto pelo Programa resultaram em novas discussões sobre uma maneira mais elaborada para atrair o capital privado na expansão da geração com fontes renováveis, com maior poder de sedução sobre os potenciais investidores, porém, ao mesmo tempo, com redução nos custos de desenvolvimento dos projetos.

Tais fontes têm a característica de serem de porte menor do que as convencionais exploradas no País, o que prejudica a economia de escala e, ainda, se encontram em fase de consolidação da cadeia produtiva, razão pela qual foram criados subsídios do governo, ou incentivos, para tornálas comercialmente atrativas. Por essa razão, existe um mecanismo de descontos associado à negociação da energia proveniente de tais fontes. O principal destino dessa energia são os Consumidores Especiais, tipo de consumidor livre que deve, obrigatoriamente, adquirir energia especial $^{11}$ caso opte por negociar energia no mercado e não mais ser atendido pela Concessionária de Distribuição local, através de tarifa regulada. Dessa forma, aumentar-se-ia a captação de investimentos privados para a expansão da capacidade de geração em energia renovável, criando condições para que haja demanda de energia das usinas incentivadas, reduzindo os custos para a sociedade, além de promover a construção de empreendimentos de fontes alternativas de forma mais eficaz.

Em 1998, através da Lei 9.427, foi introduzido o conceito de consumidor especial, como sendo aquele consumidor cuja demanda mínima é de $500 \mathrm{~kW}$, podendo ser atendido em qualquer nível de tensão, desde que a energia adquirida para lastrear 100\% de seu consumo seja proveniente de fontes primárias incentivadas. Para a negociação envolvendo tais empreendimentos, ficou estipulado que a ANEEL deverá determinar um percentual de desconto nas tarifas de uso dos sistemas de transmissão (TUST) e distribuição (TUSD), não inferior a 50\%, tanto para os produtores quanto para aqueles que adquiram energia proveniente dessas fontes.

\footnotetext{
${ }^{11}$ Energia Especial: as usinas a biomassa, solar, eólica e hidrelétricas com capacidade instalada maior que 30MW e igual ou menor que $50 \mathrm{MW}$ não são consideradas fontes incentivadas nem convencionais. A energia gerada por essas fontes confere lastro aos consumidores especiais (pois não é convencional), porém não confere desconto na tarifa de energia (pois não é incentivada). Na Câmara de Comercialização de Energia Elétrica, são identificadas pelo símbolo I0, que se lê "incentivada com desconto 0".
} 
A ANEEL regulamentou a comercialização de energia das fontes incentivadas ${ }^{12}$, por meio da publicação da Resolução no 247 de 2006.

Os critérios de caracterização de um Consumidor Livre foram bastante flexibilizados, pois o limite de $500 \mathrm{~kW}$ deixou de ser verificado por unidade consumidora do Grupo $\mathrm{A}^{13}$, passando a ser verificado também por conjunto de unidades consumidoras atendidas em alta tensão, integrantes de um mesmo submercado, reunidas por comunhão de interesse de fato ou de direito.

Por outro lado, os vendedores também tiveram alterações com relação à sua definição. As condições para comercialização de energia com os consumidores especiais passaram a ser:

- Aproveitamentos de potencial hidráulico de potência superior a 1 MW e igual ou inferior a $30 \mathrm{MW}$, mantidas as características de PCH.

- Empreendimentos com potência instalada igual ou inferior a $1 \mathrm{MW}$.

- Empreendimentos com base em fontes solar, eólica e biomassa, cuja potência injetada na linha de distribuição ou transmissão seja menor ou igual a 30 MW.

O consumidor final, que lastreia seu consumo em contratos provenientes de fontes incentivadas, recebe o desconto da fonte, ou seja, o vendedor repassa o desconto ao comprador.

Para manutenção do percentual de desconto estabelecido pela ANEEL, o limite de injeção de 30MWmed nos sistemas de transmissão e distribuição deve ser respeitado. Caso a CCEE apure, em um determinado mês, que esse volume ultrapassou o limite em três ou mais períodos de comercialização, o agente gerador de energia incentivada perderá o desconto naquele mês. Caso haja reincidência de ultrapassagem durante os próximos 12 meses, o agente gerador perderá a condição de vendedor de energia incentivada pelo período de um ano, sendo modelado sob um perfil convencional na CCEE. Durante esse período, o gerador não se beneficiará de descontos na TUST/TUSD e os eventuais contratos de venda de energia incentivada não possuirão mais desconto associado.

Em 2010 uma nova mudança à comercialização de energia com os consumidores especiais, criou o conceito de energia convencional especial. Tal mudança foi embasada na ampliação da oferta

\footnotetext{
${ }^{12}$ Fontes Incentivadas - Pequenas Centrais Hidrelétricas com potência de 1 MW a 30 MW e empreendimentos com base em fontes solar, eólica e biomassa com potência menor ou igual a $30 \mathrm{MW}$.

13 Grupo A - Grupamento composto de unidades consumidoras com fornecimento em tensão igual ou superior a $2,3 \mathrm{kV}$, ou ainda, atendidas em tensão inferior a $2,3 \mathrm{kV}$ a partir de sistemas subterrâneo de distribuição. Resolução ANEEL n ${ }^{\circ} 456 / 00$.
} 
de energia para os consumidores especiais, prevista pela Lei 11.943 de 2009, que permite aos geradores com potência injetada entre 30.000 e $50.000 \mathrm{KW}$ comercializarem energia com estes consumidores, concedendo-lhes lastro de energia, porém sem desconto associado. A partir desse momento, a energia que pode ser adquirida por um consumidor especial precisou ser desvinculada do conceito de incentivada, uma vez que não necessariamente existe um desconto atrelado à energia que compõe o lastro desses consumidores.

Dessa forma, a energia pode ser dividida nas seguintes categorias, em termos de desconto e de composição de lastro:

- Energia Incentivada: energia proveniente dos empreendimentos com desconto associado, conforme REN 247/2006, e que conferem lastro aos consumidores especiais e que participam da matriz de descontos;

- Energia Convencional Especial: energia proveniente dos empreendimentos com potência injetada entre 30.000 e $50.000 \mathrm{KW}$, que confere lastro aos consumidores especiais, porém não incidem descontos na TUST/TUSD para os envolvidos;

- Energia de Cogeração Qualificada: energia proveniente de empreendimentos que obedecem ao disposto na Resolução Normativa n ${ }^{\circ}$ 235, de 14 de novembro de 2006, e que conferem lastro e desconto aos consumidores livres, porém não pode ser negociada com os consumidores especiais;

- Energia Convencional: energia sem desconto e que não confere lastro ao consumidor especial. Além disso, foi permitida a participação das comercializadoras na compra e venda de energia de fonte incentivada, fato que na legislação anterior não era permitido, pois a energia devia ser negociada diretamente entre o produtor e consumidor.

A resolução também estabeleceu que o potencial consumidor especial deve declarar formalmente a intenção de migrar para o mercado livre à concessionária de distribuição com antecedência de 180 dias. O mesmo prazo foi inicialmente definido com relação à saída do mercado livre e retorno para mercado cativo. Alteração recente advinda com a Lei 12.783/2013 estabelece que caso os consumidores especiais queiram retornar ao ambiente regulado, precisarão observar a mesma carência dos consumidores livres normais (com demanda acima de 3MW) - com obrigação de comunicar essa migração com cinco anos de antecedência. 
Para fins de lastro de venda ${ }^{14}$, o agente gerador incentivado deve registrar somente contratos de energia incentivada, tanto na compra como na venda. Caso o empreendimento não possua Garantia Física homologada pela ANEEL, o lastro mensal do gerador de energia incentivada é a própria geração apurada na CCEE no mês. Isso significa que, caso o gerador gere menos energia do que seu contrato de venda exige no período, deverá recompor com energia incentivada, caso contrário o repasse será prejudicado. Para as PCHs pertencentes ao Mecanismo de Realocação da Energia (MRE), a apuração do lastro será feita após a aplicação desse mecanismo.

Para fins de complementação de geração, o agente gerador incentivado pode registrar contratos de compra de fontes convencionais, limitado até $49 \%$ da sua garantia física, baseado nos últimos 12 meses. Basicamente, essa compra serve para reduzir a exposição ao PLD do gerador, sem efeito para fins de composição de lastro quanto a penalidades e implicando também na perda do desconto na tarifa fio na proporção do volume convencional sobre o total. Neste caso, o gerador mantém o desconto da usina, prejudicando apenas o repasse de desconto na matriz de comercialização de energia incentivada. Essa possibilidade de compra é permitida com o objetivo de mitigar os riscos de sazonalização das fontes incentivadas. Mais adiante no Capítulo 6 (item 6.3) será detalhada a questão de apuração do desconto e penalização por insuficiência de lastro de um agente incentivado.

Com a finalidade de garantir que um gerador incentivado repasse o desconto integral de suas usinas ao consumidor final, o comprador, foi necessário separar a comercialização de energia incentivada da energia convencional. Isto foi feito via modelagem, ou seja, segregando a comercialização em dois "mundos" diferentes, o mundo convencional e mundo incentivado.

Em novembro de 2007 a ANEEL, por meio da Resolução Normativa n²86, homologou as regras da comercialização da energia incentivada Segundo estas regras, o desconto pode sofrer reduções em duas circunstâncias. Na primeira, quando o gerador não respeita a proibição de ultrapassagem do limite $49 \%$ da garantia física ${ }^{15}$ de complementação com energia convencional, o que implica em desconto igual zero para todas as usinas de sua propriedade, além de incidência

\footnotetext{
${ }^{14}$ Lastro de Venda - Os vendedores de energia devem apresentar energia vinculada às usinas de sua propriedade, ou contratos de compra para lastrear a venda de energia elétrica. Caso o vendedor apresente lastro inferior a $100 \%$ o agente fica sujeito à penalidade.

${ }^{15}$ O limite de compra de energia convencional em 49\% da Garantia Física tem a finalidade de exercer o papel de um mecanismo de mitigação de riscos aos preços de curto prazo.
} 
de penalidade por insuficiência de lastro, resultando na perda de desconto também para os seus compradores. Na segunda, quando o agente realiza uma venda maior do que o lastro que o mesmo dispõe, resultando em aplicação de penalidade e no repasse de um desconto proporcional aos seus compradores. Nesta circunstância se enquadra o gerador que compra energia convencional para complementação de até $49 \%$ da garantia física. O desconto proporcional também acontece se o consumidor apresentar um consumo maior do que o montante contratado.

Para os agentes de geração e comercialização de energia incentivada, o desconto associado aos seus contratos de venda será a média global dos descontos de suas usinas associadas e contratos de compra de energia incentivada especial, ponderada pelo máximo valor entre (i) a garantia física apurada mais contratos de compra de energia incentivada especial, e (ii) os contratos de venda de energia incentivada especial em um determinado mês.

Para comercializadores sem usinas associadas, a aferição é feita utilizando-se apenas contratos de energia incentivada. Isso significa que pode ocorrer perda no repasse do desconto quando o vendedor negocia energia sem lastro suficiente para cobrir suas operações envolvendo energia incentivada.

Para os agentes consumidores livres e autoprodutores, o desconto associado ao uso dos sistemas de transmissão ou distribuição será o valor da média global dos descontos fornecidos pelos contratos de energia incentivada, ponderado pelo maior valor entre o montante total de energia incentivada adquirida e o consumo mensal.

Para os consumidores especiais, são utilizados no cálculo os contratos de energia incentivada especial. Caso a quantidade de energia incentivada adquirida seja inferior ao consumo em um determinado mês, este agente perderá uma parte do desconto, proporcional ao montante descoberto. Adicionalmente, o consumidor poderá perder parte do desconto caso o fornecedor de energia incentivada repasse um percentual de desconto reduzido.

\subsection{A Renovação das Concessões Vincendas e Redução da Tarifa de Energia}

O setor de energia vem, desde o segundo semestre de 2012, enfrentando diversas alterações em seu marco regulatório, cujos efeitos têm se traduzido em impactos relevantes para todos os 
agentes atuantes no setor, sejam geradores, transmissores, distribuidores, comercializadores ou consumidores (livres ou regulados).

Destacam-se os seguintes temas:

- Prorrogação das concessões dos segmentos de geração, transmissão e distribuição com vencimento até 2017 visando a modicidade tarifária;

- Redução dos encargos setoriais e redefinição dos múltiplos usos dos recursos da CDE;

- Auxílio financeiro às distribuidoras para suportar os efeitos conjunturais do ano de 2013 e 2014;

- Alteração das regras de formação de preços no mercado de curto prazo com a incorporação dos procedimentos de aversão ao risco nos modelos computacionais; e

- Término da contratação ex-post no mercado de curto prazo. (Portaria MME 455/2012, objeto de controvérsias entre os agentes e, portanto, ainda não validado);

- Introdução do mecanismo de bandeiras tarifárias a partir de 2015. Cria uma relação entre o valor pago pelo consumidor e o custo atualizado arcado pelas geradoras. Além de indicar que o custo de geração de energia está elevado, por conta do acionamento de termelétricas para poupar água nos reservatórios, o sistema de bandeiras repassa mensalmente às tarifas parte dos custos adicionais na geração. Com isso, a receita que as distribuidoras tiverem com o pagamento será descontada do cálculo do reajuste tarifário anual.

No dia 11 de setembro de 2012 o governo anunciou um programa, criado pela Medida Provisória 579 de 2012 e regulado pelo Decreto 7.805 de 2012, que trata da redução das tarifas de energia em média 20,2\% a partir de 2013. Baseia-se em dois pontos principais:

- Renovação das Concessões de Geração, Transmissão e Distribuição que expirarão entre 2015 e 2017, mediante antecipação dos efeitos financeiros nas tarifas dos consumidores já a partir de 2013;

- Alteração do regime de comercialização de energia das concessões de geração vencidas: rateio da energia por meio de cotas de garantia física e de potência distribuídas entre os consumidores regulados com pagamento de tarifa regulada; 
- Redução de Encargos Setoriais ${ }^{16}$, grande parte por meio de aportes de recursos do Tesouro.

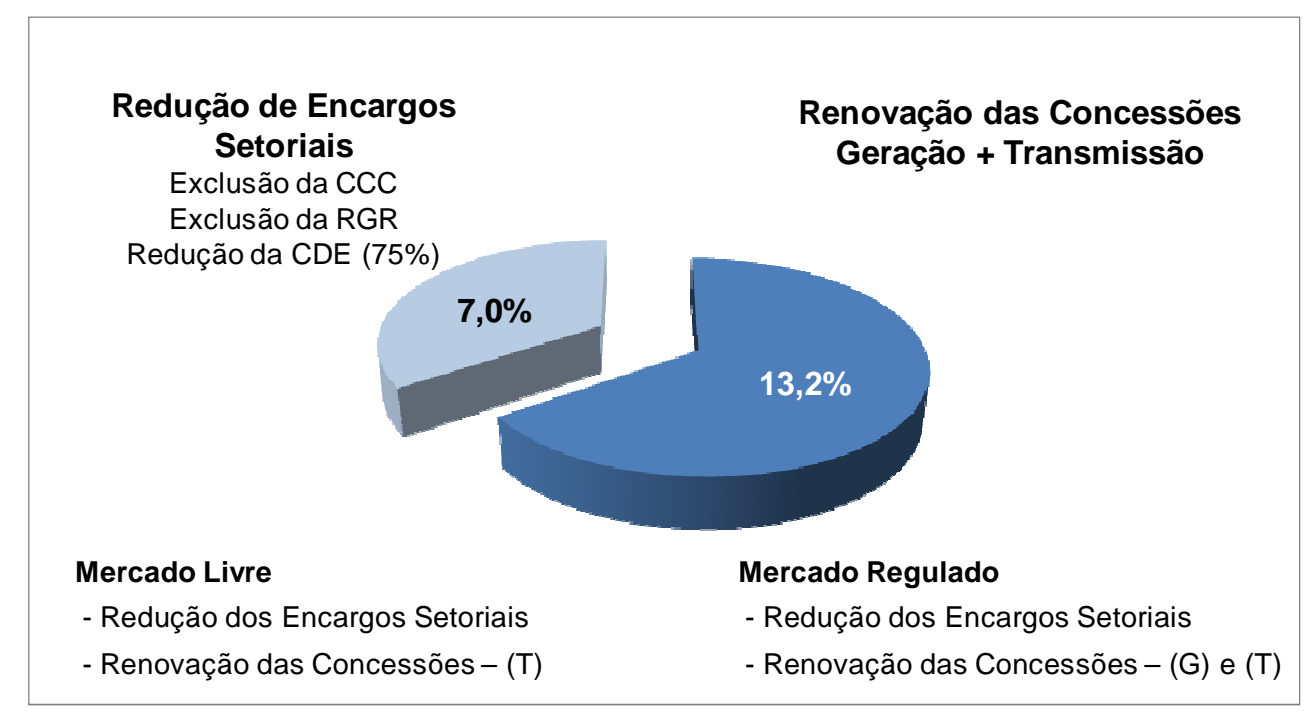

Figura 6 - Redução da Tarifa de Energia - MP579/2012 (Fonte: Confecção própria)

Tal programa previa que as concessões expirando entre 2015 e 2017 teriam a renovação antecipada para 2013 implicando em uma redução média da tarifa de 13,2\%.

Entretanto, algumas empresas estatais de geração não aderiram à renovação antecipada, sendo mantidas as concessões até o fim de suas vigências. Findo o prazo destas concessões, haverá licitação para operar e manter a usina já depreciada ao custo mais baixo, com o propósito da modicidade tarifária. O concessionário de geração terá que maximizar sua eficiência operacional para obter ganhos reais com o negócio.

Em relação ao desconto prometido, como não houve adesão de todos os agentes envolvidos na renovação das concessões, o governo passou a realizar aportes adicionais do dinheiro do Tesouro Nacional na Conta de Desenvolvimento Energético - CDE para que sejam repassados às Distribuidoras e, consequentemente, à tarifa de energia dos consumidores cativos.

Analisando os possíveis impactos desta medida no preço e na comercialização de energia, podese concluir que o volume de energia das concessões renovadas convertido em cota não deve provocar desequilíbrio de oferta de energia entre os mercados regulado e livre:

16 CCC - Conta de Consumo de Combustíveis Fósseis CDE - Conta de Desenvolvimento Energético

RGR - Reserva Global de Reversão 
A redução das tarifas de energia pode afetar indiretamente o preço no mercado livre, mas o ACL continuará sendo um ambiente relevante e economicamente atrativo.

Antes da MP579, os preços no mercado livre já estavam menores que as tarifas de energia do mercado regulado e devem continuar menores mesmo depois de sua vigência;

Apesar do efeito da redução na tarifa de energia ser específico para cada distribuidora, a maioria delas continuará com tarifas de energia superiores ao preço praticado no mercado livre.

- Uma maior racionalidade econômica é esperada no mercado livre uma vez que um volume relevante de energia amortizada de agentes federais e estaduais está agora restrito ao mercado regulado.

O impacto financeiro nas empresas federais e estaduais pode comprometer a capacidade de investimento dessas empresas e pressionar os preços de energia nova.

O mercado livre continuará influenciado por:

$\checkmark$ Mercado de curto prazo (prazo de retorno de 5 anos) - volatilidade, despacho térmico;

$\checkmark$ Preço de energia nova - tendência de alta;

$\checkmark$ Balanço de oferta e demanda de lastro - crescimento da demanda pode esgotar rapidamente a folga existente; atrasos em construção de novas usinas e linhas de transmissão também podem reduzir a folga indicada atualmente;

$\checkmark$ Custo de energia comprada no mercado regulado - apesar da redução, ainda ficará acima dos preços do mercado livre.

Em função da conjuntura crítica desde o final de 2012, com hidrologia muito abaixo da média, culminando com um despacho térmico na base e alto custo associado, penalizando consumidores, geradores e, sobretudo, distribuidoras, as quais repassam estes custos às tarifas somente no reajuste anual; além da subcontratação das distribuidoras, pela não adesão de alguns geradores à renovação das concessões, implicando em exposição a elevados preços no mercado spot, foi necessário um aporte total do Tesouro superior a $\mathrm{R} \$ 11$ bilhões aos concessionários de distribuição. Somado a isto, foram necessários empréstimos bancários feitos pela CCEE e repassados às distribuidoras no montante de $\mathrm{R} \$ 21,2$ bilhões. Tais somas serão repassadas às tarifas a partir de 2015 pelos próximos 5 anos e representarão incrementos superiores a 15\%. 


\subsection{Introdução de Mecanismos de Aversão ao Risco nos Modelos Computacionais que definem o despacho hidrotérmico e a questão do custo do despacho térmico adicional}

Posteriormente à adoção da Curva de Aversão ao Risco ${ }^{17}$ no modelo Newave, com o objetivo de garantir maior segurança no abastecimento e minimizar os riscos de racionamento, o CNPE estabeleceu que, extraordinariamente, com vistas à garantia do suprimento energético, o ONS poderia despachar recursos energéticos das usinas térmicas fora da ordem do mérito econômico ou mudar o sentido do intercâmbio entre submercados, por decisão do Comitê de Monitoramento do Setor Elétrico - CMSE. Determinou que o despacho de recursos para recuperar o nível de segurança (CAR) não seria computado na formação do PLD. Aprovou-se então uma sistemática para a determinação do acionamento extraordinário de usinas térmicas por razão de segurança energética, chamados de Procedimentos Operativos de Curto Prazo - POCP, os quais se baseiam na definição de níveis meta para o mês de novembro de cada ano, nas regiões $\mathrm{SE} / \mathrm{CO}$ e NE.

No entanto, o distanciamento entre a formação de preços (que se baseia no critério de mínimo custo) e a operação (que incorpora a aversão a risco através da consideração de aspectos adicionais de segurança energética) reduz a sinalização econômica do preço de curto prazo. É imperioso manter a sinalização adequada, posto que os preços de curto prazo exercem importante papel no funcionamento do mercado de energia elétrica, representando o comprador e o vendedor de última instância e influenciando todos os demais preços do próprio mercado. É também um sinalizador da eficiência econômica, sendo a eficiência de curto prazo associada ao despacho.

Uma influência importante dos mecanismos de despacho extraordinário por segurança energética diz respeito à formação do PLD. A utilização destes mecanismos complementares de acionamento de usinas térmicas influencia o nível de armazenamento dos reservatórios e pode provocar uma redução artificial no PLD nos estágios seguintes, podendo implicar na ocorrência de um ciclo vicioso.

17 É a curva que representa a evolução, ao longo do tempo, dos requisitos mínimos de armazenamento de energia de cada subsistema, necessários ao atendimento pleno da carga. Para definição da curva são consideradas hipóteses pré-determinadas de afluências, intercâmbios inter-regionais e carga, toda a geração térmica (inclusive as térmicas emergenciais) despachada em sua produção máxima, de forma a se garantir níveis mínimos operativos ao longo do período. Em outras palavras, para garantir o atendimento do mercado e assegurar a capacidade de recuperação dos reservatórios, os níveis de armazenamento do reservatório equivalente de uma região devem ser mantidos sempre acima da curva de aversão ao risco ao longo de cinco anos. 
Neste contexto, a Resolução n⿳3 3 de 2013 do Comitê Nacional de Política Energética determina a internalização de mecanismo de aversão a risco nos programas computacionais para estudos energéticos (planejamento) e formação de preço (operação).

O objetivo é diminuir os repasses da geração térmica (por meio de Encargos de Serviço do Sistema) aos consumidores, uma vez que os PLDs capturarão "em tese" os despachos que até então eram realizados fora da ordem de mérito por razões de segurança de suprimento e pelo rateio dos custos com todos os agentes do mercado: distribuidoras, geradoras, comercializadoras e consumidores livres na proporção de sua energia comercializada ${ }^{18}$ nos últimos 12 meses.

Do ponto de vista estrutural, vários fatores contribuem para tornar necessário o acionamento mais frequente de usinas termelétricas para atender à demanda. Dentre estes, destaca-se a redução da capacidade de regularização dos reservatórios das usinas hidrelétricas, pela redução relativa da capacidade de armazenamento vis-à-vis ao crescimento do consumo de energia elétrica, e inserção de fontes intermitentes de energia.

Nos modelos anteriores, o problema de otimização do despacho hidrotérmico foi concebido com o critério de mínimo custo total, onde o objetivo é obter uma política de operação que minimize o valor esperado da geração térmica e eventuais cortes de carga, a qual é avaliada para um dado conjunto de possíveis cenários de afluências futuras aos reservatórios. O impacto de cenários hidrológicos mais severos na política de operação é considerado de maneira indireta, por meio de sua contribuição para o valor esperado (média) dos custos operativos. Em decorrência, não há garantia de proteção para os eventos de maior arrependimento que correspondem à ocorrência de séries hidrológicas críticas (muito secas) e à violação de níveis desejáveis de segurança.

Neste contexto, foi implementado, portanto, o mecanismo de aversão a risco CVaR que visa dar maior importância aos cenários hidrológicos mais críticos no cálculo da política de operação, da seguinte forma:

a função objetivo, além de minimizar o valor esperado do custo total de operação com um determinado peso $\Lambda-1$, considera também uma parcela adicional referente ao custo dos cenários hidrológicos mais críticos, com um peso $\Lambda$;

18

Energia Comercializada $=$

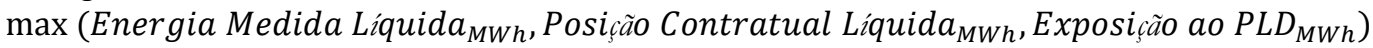


o conjunto de cenários hidrológicos mais críticos é identificado por meio de um parâmetro $\alpha$, relacionado ao nível de proteção e que indica o percentual do total dos cenários daquele período que será considerado com custo adicional na função objetivo.

\section{Otimização = Minimizar $((1-\Lambda)$.Valor Esperado $\left.+\Lambda \cdot \mathrm{CVaR}_{50 \%}\right)$ da Distribuição de Custos de Operação}

A determinação dos valores dos parâmetros $\Lambda(25 \%)$ e $\alpha(50 \%)$ estão associadas ao maior ou menor grau de aversão ao risco que se deseja adotar. A política de operação se torna tanto mais avessa ao risco quanto mais o valor de $\Lambda$ se aproximar de 1 , e quanto mais o percentual $\alpha$ se aproximar de zero. Ressalta-se que, no caso multi-estágio, o nível $\alpha$ não corresponde à interpretação usual de serem os $\alpha \%$ cenários mais críticos utilizados em simulações com o modelo, do primeiro ao último ano do horizonte de planejamento. A cada estágio, este parâmetro corresponde aos $\alpha \%$ cenários mais críticos do próprio estágio. Portanto, no caso de CVaR puro $(\Lambda=1)$, a aplicação do fator $\alpha$ em um contexto multi-estágio de T períodos leva a um nível de proteção de $\alpha \mathrm{T}$.

Assim, em sistemas hidrotérmicos, estes mecanismos buscam antecipar o despacho de geração térmica com custos unitários de operação (CVUs) mais baixos, com o intuito de evitar o atingimento, no futuro, de níveis indesejáveis de armazenamento nos reservatórios das usinas hidroelétricas e, com isso, minimizar o risco de déficits de energia, mas sem onerar em demasia os custos de operação do sistema.

A introdução de mecanismos de aversão a risco traz ainda como benefício, além do aumento da segurança, o adequado reflexo da formação do preço de liquidação no mercado de curto prazo e uma maior coerência entre as atividades de planejamento e operação. 


\section{DEFINIÇÃO DE ESTRATÉGIA DE COMERCIALIZAÇÃO DE ENERGIA PARA AGENTES GERADORES}

A definição da estratégia de comercialização de energia de um Gerador passa pela melhor distribuição de sua energia disponível para contratação entre ambos os ambientes de comercialização, o regulado (ACR) e o livre (ACL).

Neste ponto, uma primeira importante decisão deve ser tomada: qual percentual de sua energia assegurada um Gerador deve ou pode comercializar, sem arriscar-se excessivamente, considerando a possibilidade de cenários hidrológicos desfavoráveis e consequente aumento de preço e baixa alocação de energia no MRE, deixando-o exposto ao mercado Spot?

Para facilitar a compreensão desta questão, apresentam-se dois importantes conceitos, a saber: Garantia Física e Mecanismo de Realocação de Energia (MRE).

\subsection{Garantia Física}

A garantia física do SIN é definida como aquela correspondente à máxima quantidade de energia que este sistema pode suprir a um dado critério de garantia de suprimento. Esta energia é rateada entre todos os empreendimentos de geração que constituem o sistema, a fim de se obter a garantia física dos empreendimentos com vistas à comercialização de energia via contratos. $\mathrm{O}$ valor de garantia física é fornecido para cada agente de geração pelo MME através de uma portaria específica. Para aquelas usinas que não possuem garantia física definida pelo MME, seu lastro passa a ser a própria geração.

No processo de contabilização da CCEE, eventuais contratos de compra de energia são somados à garantia física ou à geração para composição do lastro total do agente no período em questão. No caso de agente com garantia física definida pelo MME, a apuração do recurso necessário para cobertura do compromisso contratual do agente vendedor leva em conta a garantia física alocada àquele mês em contabilização. Uma vez que o requisito (compromisso de venda) esteja igual ou abaixo do recurso, o agente não está sujeito a penalidades por falta de lastro de energia. Entretanto, caso a geração efetiva seja diferente da garantia física alocada, isso levará a uma exposição no mercado Spot. 
No caso de um empreendimento no ACL, cuja apuração difere do ACR por ser feita em base mensal e não anual, tais variações colocam o agente em risco devido à exposição ao PLD. Caso a geração seja superior à garantia física alocada e o PLD esteja abaixo do preço de contrato, o agente poderia ter alocado essa energia em outro momento e ganha-se a diferença entre o preço do contrato e o PLD. De forma análoga, caso a geração fique abaixo da garantia física alocada e o PLD esteja mais alto que o preço do contrato, o agente perde a diferença entre o PLD e o preço do contrato.

\subsection{Mecanismo de Realocação de Energia - MRE}

O Mecanismo de Realocação de Energia é um mecanismo de compartilhamento de riscos hidrológicos implementado para corrigir a distorção na alocação dos benefícios econômicos aos agentes cujas usinas hidroelétricas estão em cascata, quando as usinas a jusante, despachadas posteriormente às usinas a montante quando o CMO e PLD já apresentavam um valor mais elevado, capturavam uma renda maior e que em parte pertencia às usinas com reservatórios a montante, uma vez que se aproveitam da vazão afluente mais elevada em razão do deplecionamento de reservatórios a montante, justamente nos momentos que o preço do MCP já está mais elevado.

A operacionalização do MRE consiste em fazer com que cada usina atinja a quantidade de garantia física alocada naquele período de comercialização. Uma vez que o despacho é centralizado e existem variações sazonais entre as diversas regiões do SIN, a quantidade de energia gerada por uma usina será, na grande maioria das vezes, diferente do valor de garantia física alocada para o período em questão. É feita, portanto, uma alocação contábil de energia entre as usinas participantes do mecanismo, transferindo energia, em um dado período de comercialização, daquelas que geram acima da sua Garantia Física para aquelas que geram abaixo.

Quando a energia total produzida pelas usinas do SIN é superior à garantia física total, esse superávit de energia é denominado Energia Secundária e é rateado entre todas as usinas participantes do mecanismo, na proporção de sua garantia física. Em contrapartida, caso o sistema como um todo apresente déficit, mesmo uma usina superavitária irá ter sua garantia física para fins de contabilização da CCEE reduzida proporcionalmente. 
Uma das implicações deste mecanismo é que os proprietários das usinas hidroelétricas não são afetados pelas decisões operativas do ONS, pois seu pagamento "spot" na CCEE está associado à geração total do sistema hidroelétrico, não à sua geração física individual.

Vale ressaltar ainda que, como a geração física total do sistema hidroelétrico é muito mais constante do que a produção individual, o MRE ajuda a reduzir a volatilidade dos pagamentos "spot" na CCEE.

O MRE está regulamentado apenas para fontes hidrelétricas e a participação de usinas com capacidade instalada acima de 30MW ou aquelas abaixo, mas que são despachadas centralizadamente, é obrigatória. Às demais usinas, no caso PCHs e CGHs, a participação é facultativa. A permanência no mecanismo, entretanto, é condicionada a critérios de geração mínima, de acordo com o estabelecido na Resolução Normativa 409/2010.

\begin{tabular}{|c|c|}
\hline $\begin{array}{c}\text { Número de meses registrados na CCEE } \\
\text { posteriores ao décimo segundo mês de operação } \\
\text { comercial }(\mathrm{m})\end{array}$ & $\frac{G M}{G F} * 100$ \\
\hline $24 \leq \mathrm{m}<36$ & $\geq 10 \%$ \\
\hline $36 \leq \mathrm{m}<48$ & $\geq 55 \%$ \\
\hline $48 \leq \mathrm{m}<60$ & $\geq 60 \%$ \\
\hline $60 \leq \mathrm{m}<72$ & $\geq 65 \%$ \\
\hline $72 \leq \mathrm{m}<84$ & $\geq 70 \%$ \\
\hline $84 \leq \mathrm{m}<96$ & $\geq 75 \%$ \\
\hline $96 \leq \mathrm{m}<120$ & $\geq 80 \%$ \\
\hline $\mathrm{m} \geq 120$ & $\geq 85 \%$ \\
\hline
\end{tabular}

Tabela 2 - Metas de Geração para permanência no MRE

Sendo:

GM: geração média de energia elétrica, expurgando os 12 primeiros meses;

GF: garantia física do empreendimento vigente à época do cálculo.

O empreendimento excluído do MRE somente poderá retornar quando os referidos limites forem atendidos, seja em função do novo valor de geração média de energia elétrica, seja em função de revisão da respectiva garantia física pelo Ministério de Minas e Energia.

\subsection{Precificação de Contratos no ACR: Índice de Custo/Benefício (Contratos por Disponibilidade)}

Da Nota Técnica da EPE “Índice de Custo Beneficio (ICB) de Empreendimentos de Geração Termelétrica Metodologia de Cálculo", se estabelece que o Índice de Custo Benefício é o método utilizado para avaliar os projetos nos leilões de energia nova. Uma vez calculados os índices ICB para cada 
projeto, o critério de decisão consiste em se investir nos projetos por ordem crescente de ICB, ou seja, do menor para o maior valor de ICB.

O ICB é obtido como se segue:

$$
I C B=\frac{\text { Custos Fixos }+E(\text { Custo de Oper.) }+ \text { E(Custo Econ.Curto Prazo })}{\text { Garantia Física }}
$$

A parcela Custos Fixos - CF (em R\$/ano) representa a receita requerida pelo investidor de forma a cobrir o custo total de implantação do empreendimento, incluindo os custos socioambientais, os juros durante a construção, e a remuneração do investimento, além de todos os custos fixos relativos à operação de inflexibilidade operativa ("take or pay" e "ship or pay"), o custo de conexão à rede básica e tarifas de uso dos sistemas de transmissão e distribuição (TUST e TUSD), etc.

A parcela Custo Variável de Operação - COP (em R\$/ano) é função do nível de inflexibilidade no despacho da usina (contratos de combustível "take or pay") e do custo variável de O\&M, declarados pelo empreendedor, os quais determinam sua condição de despacho flexível em função também dos custos marginais de operação (CMO) futuros observados no SIN. Tratase, portanto, de uma variável aleatória cujo valor esperado é calculado com base em uma amostra de valores de CMO divulgada pela EPE.

A parcela Custo Econômico de Curto Prazo - CEC (em R\$/ano) resulta das diferenças mensais apuradas entre o despacho efetivo da usina e sua Garantia Física. Esta parcela corresponde ao valor acumulado das liquidações no mercado de curto prazo, feitas com base no Custo Marginal de Operação - CMO (com os limites de piso e teto impostos ao PLD). Seu valor também é função do nível de inflexibilidade no despacho da usina e do custo variável de O\&M, declarados pelo empreendedor. Trata-se também de uma variável aleatória cujo valor esperado é calculado com base em uma amostra de valores de CMO divulgada pela EPE.

O denominador Garantia Física - GF corresponde à energia assegurada (em MWmédio) do empreendimento de geração e também é função do nível de inflexibilidade no despacho da usina e do seu custo variável unitário, conforme declarados pelo empreendedor. 
No caso de um empreendimento em que apenas uma fração (x) de sua energia assegurada seja destinada ao ACR, sendo o restante reservado para uso próprio ou para comercialização no ACL, o índice ICB será calculado admitindo-se que todas as parcelas de custo e de benefício definidas acima variem proporcionalmente à fração de energia assegurada destinada ao ACR.

Neste caso, o índice ICB pode ser redefinido da seguinte maneira:

$$
I C B=\frac{x C F}{x G F}+\frac{x(C O P+C E C)}{x G F}
$$

Reinterpretando o numerador e denominador do primeiro termo e observando que o fator $\mathrm{x}$ se cancela no segundo termo, pode-se então escrever:

$$
\begin{gathered}
I C B=\frac{R F}{8760 \times Q L}+\frac{C O P+C E C}{8760 \times G F} \\
I C B=\frac{R F}{8760 \times Q L}+K
\end{gathered}
$$

onde:

RF é a Receita Fixa requerida pelo empreendedor, relativa à quantidade de lotes (QL) ofertada para o ACR, em R \$/ano (igual a x.CF);

QL é a Quantidade de Lotes (0,1 ou 1 MWmédio) ofertada para o ACR limitada a GF (igual a x.GF);

$\mathbf{K}$ é a parcela invariante do índice, em $\mathrm{R} \$ / \mathrm{MWh}$, destinada à cobertura dos custos variáveis de operação e custos econômicos no mercado de curto prazo, calculada para o empreendimento como um todo (válido para qualquer valor de x).

Desta forma, durante o processo de leilão de energia proveniente de novos empreendimentos, o índice ICB será calculado pelo sistema aplicando-se a expressão (3) com base nos valores de Receita Fixa (RF) e Quantidade de Lotes (QL) submetidos pelo empreendedor na ocasião e no valor da parcela $\mathrm{K}$ relativa ao novo empreendimento, calculada antecipadamente pela EPE a partir dos dados fornecidos pelos empreendedores. Vale ressaltar que o índice ICB assim calculado possibilita a comparação de projetos termelétricos para qualquer valor de fração x, no 
intervalo $0 \leq \mathrm{x} \leq 1$. O edital de licitação poderá, no entanto, definir um percentual mínimo de GF destinado à comercialização no ACR (valor mínimo para x).

Primeiramente, os custos marginais de operação (CMO) são obtidos a partir dos resultados da simulação do modelo NEWAVE. Em seguida, para o cálculo do ICB, adota-se o mesmo critério de despacho das usinas termelétricas usado pelo ONS, tendo em vista a otimização da operação energética integrada do SIN, lembrando que uma usina termelétrica pode vir a gerar acima de sua inflexibilidade declarada em duas situações:

I. na condição de despacho por mérito econômico, sempre que o CMO supera seu custo variável;

II. por segurança energética, em função de níveis de armazenamento pouco confortáveis, ou razões elétricas, devido a alguma necessidade do sistema de transmissão, quando então faz jus a receber Encargos por Serviços ao Sistema. Nesta condição o CMO é maior que o custo variável.

Dada a sua imprevisibilidade, esta situação não é considerada no cálculo do ICB e, por conseguinte, a regra de despacho mensal simulada no cálculo do ICB é a regra válida em condições normais, ou seja, quando seu Custo Variável Unitário (CVU) for inferior ao CMO, a usina estará despachada no limite de sua disponibilidade, caso contrário, a usina irá gerar o equivalente à sua inflexibilidade, o que pode ser representado matematicamente por:

$$
\left\{\begin{array}{c}
\text { se } C M O_{s, c, m} \geq C V \Rightarrow \text { Gera }_{c, m}=\text { Disp }_{m} \\
\text { se } C M O_{s, c, m}<C V \Rightarrow \text { Gera }_{c, m}=\text { Inflex }
\end{array}\right\}
$$

Onde:

s corresponde ao índice de cada submercado (1 a 4);

c corresponde ao índice de cada cenário hidrológico (1 a 2000);

m corresponde ao índice de cada mês (1 a 120);

$\mathrm{CMO}_{\mathrm{s}, \mathrm{c}, \mathrm{m}}$ é o custo marginal de operação do submercado onde está localizada a usina para cada cenário, para cada mês, em R \$/MWh;

CV é o custo variável unitário da usina termelétrica, em R\$/MWh;

Gera $_{c, m}$ é a geração da usina termelétrica em cada mês, para cada possível cenário, em MWmédios; 
Inflex $_{\mathrm{m}}$ é o nível de inflexibilidade de despacho (ou geração mínima obrigatória) da usina termelétrica, para cada mês, em MWmédios;

Disp $_{m}$ é a disponibilidade (ou geração máxima mensal) da usina termelétrica, em MWmédios.

A disponibilidade média mensal de uma usina termelétrica é dada por:

$$
\text { Disp }=P o t \times F C_{\text {max }} \times(1-T E I F) \times(1-I P)
$$

onde,

Pot é a potência instalada da usina em MW;

FC $_{\max }$ é o percentual da potência instalada que a usina consegue gerar continuamente;

TEIF corresponde à taxa média de indisponibilidade forçada;

IP corresponde à taxa de indisponibilidade programada.

De forma geral as usinas sempre despacham sua inflexibilidade. Caso o CMO seja menor que o Custo Variável Unitário - CVU de geração da usina ela é despachada na disponibilidade máxima.

O custo variável mensal de operação leva em conta o gasto adicional da usina, considerada como um todo, quando esta tiver que gerar acima de sua inflexibilidade declarada. Este gasto compreende o custo adicional do combustível propriamente dito e os custos incrementais de operação e manutenção.

O custo econômico de curto prazo (CEC) reflete os "ganhos" ou "perdas" obtidos no mercado de curto prazo (CCEE) aplicando-se as regras de comercialização de energia de curto prazo em conjunto com a simulação da operação mensal. É calculado para a usina como um todo, para cada mês e para cada um dos 2.000 possíveis cenários. Independentemente do valor do seu CVU, a diferença entre a Garantia Física - GF e a geração despachada da usina (exposição no mês) é valorizada pelo PLD como segue:

$$
C E C_{c, m}=C M O_{s, c, m}^{*} \times\left(G F-\text { Gera }_{c, m}\right) \times n_{\text {horas }_{m}}
$$

Onde:

GF é garantia física da usina termelétrica em MWmédios;

CMO* é o valor do CMO limitado ao PLD mínimo e ao PLD máximo, vigentes no ano do leilão. 
A fórmula do CEC leva a um custo positivo quando a usina tem que "comprar" energia para honrar seu contrato, ou seja, quando sua geração mensal (Gera) for inferior à sua Garantia Física, e leva a um "custo negativo" (receita) em caso contrário.

O valor esperado anual do Custo Econômico de Curto Prazo é calculado multiplicando-se por 12 o seu valor médio mensal. Desta forma:

$$
C E C=\frac{\sum_{i=1}^{m} \sum_{j=1}^{c} C E C_{c, m}}{m \times c} \times 12
$$

Como foi apresentado anteriormente, para realizar o cálculo das parcelas variáveis do ICB (COP e CEC) é necessário saber o CVU da usina, a garantia física (GF), a disponibilidade máxima, a inflexibilidade, os 2000 cenários de CMO e os valores mínimos e máximos do PLD. A partir disso é possível calcular os valores das variáveis para cada mês de cada cenário.

\section{- CEC positivo $=$ COP nulo e CEC Negativo $=$ COP positivo.}

Isto se deve ao fato de que o COP representa o custo operacional da usina quando esta é despachada acima de sua inflexibilidade $(\mathrm{CVU}<\mathrm{CMO})$ e neste caso a usina despacha sua disponibilidade máxima e vende a diferença entre sua geração e sua garantia física no mercado de curto prazo ao valor do CMO limitado pelos máximo e mínimo do PLD, acarretando em um valor de CEC negativo. No outro caso, quando a usina não é despachada (CVU>CMO), não apresenta custos operacionais (COP) e deve comprar seu montante contratado (GF) no mercado de curto prazo, acarretando em um CEC positivo.

Q Quanto maior for o valor do CMO no mês, maior será o valor do módulo do CEC. Quando despachada $(\mathrm{CVU}<\mathrm{CMO})$ a usina terá maior retorno quanto maior o valor do CMO. Quando não despachada (CVU $>\mathrm{CMO})$ a usina terá mais gastos comprando energia no curto prazo, quanto mais próximo o valor do CMO estiver de seu CVU.

\subsection{Precificação de Contratos no ACL (Custo de Oportunidade)}

Os preços de contratos de energia são respaldados pela expectativa de preços futuros:

○ Curto Prazo:

- Hidrologia e condição do sistema (reservatórios)

○ Médio/longo Prazo: expectativa baseada nas seguintes projeções: 
- Balanço de oferta e demanda

- Custo Marginal de Operação (Preço spot), considerando as características de oferta

- Custo Marginal de Expansão, que indica o custo de novas plantas

- Custo da energia no mercado regulado como referência do custo de oportunidade para consumidores livres

Preço spot

(hidrologia e reservatórios)
Balanço de oferta e demanda
Custo Marginal de Expansão Preço no Mercado Regulado

Além de valorar as diferenças apuradas no mercado Spot da CCEE, o PLD é um balizador dos preços negociados nos contratos de curto prazo. A dinâmica das operações do mercado permite que os agentes possam fechar suas posições de forma ex-post (depois de conhecida a medição e o PLD médio mensal), de forma que sobre o valor médio de PLD os agentes pratiquem um prêmio sobre esse preço, que está diretamente relacionado à oferta e demanda por energia naquele período. Entretanto, quando mais de longo prazo for o contrato, menos influência do PLD este terá e mais próximo dos custos esperados de expansão do sistema será o valor.

De acordo com nota técnica da EPE sobre a Metodologia de Cálculo do Custo Marginal de Expansão (CME), o CME representa o acréscimo de custo para suprir um aumento unitário na demanda considerando a expectativa de custo da expansão do parque de geração de energia elétrica. A metodologia de cálculo proposta objetiva estimar o custo futuro de expansão da geração levando em consideração não somente os preços de energia previstos, mas também quais fontes de energia devem ser instaladas. Para determinação desse valor utiliza-se os preços dos empreendimentos vencedores dos leilões de energia nova, atribuindo mais peso aos certames mais recentes.

A dinâmica da formação de preço no mercado livre leva em conta também a distância ao início de suprimento e a duração do período de suprimento. 


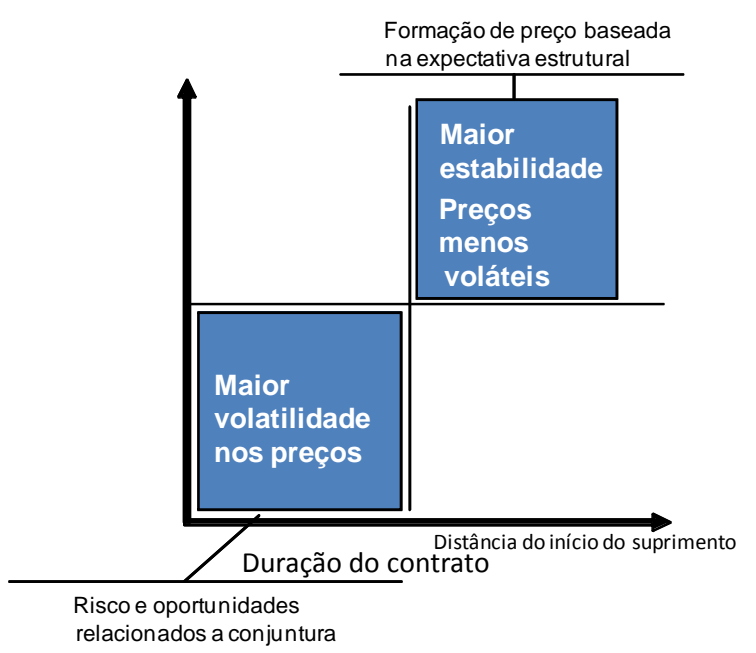

Figura 7 - Dinâmica da Formação de Preço no Mercado Livre (Fonte: Confecção própria)

O comportamento dos agentes é outro fator que afeta a dinâmica da formação de preço e impacta na liquidez dos preços de contratos. Tal comportamento é guiado por (i) situação do portfólio, (ii) aversão/apetite a risco e (iii) estratégias comerciais.

Neste contexto, as projeções de preços de contrato no mercado livre convencional são feitas sob os pontos de vista do consumidor livre e do gerador de energia: disposição a contratar do consumidor livre e a disposição a vender do gerador, de forma a estabelecer a região de negociação.

O custo de oportunidade para consumidores livres considera no ano corrente os preços de curto prazo e, a partir do ano $\mathrm{A}+2$, uma ponderação entre o custo de energia no mercado cativo e o custo marginal de expansão, além do balanço de oferta e demanda.

Já a disposição a vender dos geradores leva em conta a expectativa de preços no mercado de curto prazo e projeções dos fatores do MRE, o balanço de oferta e demanda (preço e demanda por contratos no ACL e no A-1 x oferta disponível e sobra de energia no balanço) e a aversão ao risco destes agentes.

\section{Balanço entre Oferta e Demanda de Energia}

Insuficiência de garantia física no sistema cria uma situação na qual consumidores sem contratos estariam submetidos não só ao PLD mas também a multas por insuficiência de lastro, o que aumenta a sua disposição a pagar por energia e o poder de negociação dos geradores. A parcela 
de lastro propositalmente descontratada dos geradores, como hedge ao risco hidrológico, à indisponibilidade da planta ou de recurso (combustível, vento), contribui para o desequilíbrio do balanço de oferta e demanda, acarretando em incertezas na contratação do ponto de vista da demanda (por restrição de oferta) ou em preços de contratação que aloque de forma mais racional às partes envolvidas os riscos incorridos na entrega da energia.

Por outro lado, o excesso de energia cria uma situação inversa (excesso de oferta), na qual os consumidores livres percebem uma oportunidade de adquirir energia a preços inferiores. Uma conjuntura de sobrecontratação no mercado cativo permite que o consumidor livre retorne a qualquer momento para a distribuidora. Neste caso, o risco de não conseguir um contrato de venda no ACL aliado à tendência decrescente dos preços teto nos leilões A-1 aumenta a disposição a vender do gerador no mercado livre.

\subsection{Expansão da Oferta}

Para atender ao crescimento do consumo, a taxas de $4 \%{ }^{19}$ ao ano, em média, dentro dos padrões de confiabilidade e garantia de suprimento e com critérios que prescrevem otimalidade econômica, o Conselho Nacional de Política Energética estabeleceu que a expansão deve ter sua trajetória ajustada a pontos onde o Custo Marginal de Expansão é igual ao Custo Marginal de Operação, contemplando ainda uma restrição de confiabilidade de suprimento, retratada por restrição de risco de qualquer déficit de no máximo $5 \%$ da carga (12).

De acordo com o Plano Decenal da Expansão da Energia 2022, elaborado pela EPE, a capacidade instalada do SIN irá saltar de aproximadamente 119.5 GW em dezembro de 2012 para 183 GW em dezembro de 2022. Esse incremento possui uma grande contribuição das fontes renováveis. As fontes renováveis alternativas representam 12,8\% da capacidade instalada, em um total de 15,3 GW em operação em dezembro de 2012. O planejamento da expansão prevê que as fontes renováveis não convencionais atinjam 38,2 GW de capacidade instalada em 2022, passando então a representar $20,9 \%$ da matriz energética nacional.

A estratégia de expansão para o Brasil deve-se basear em três "eixos":

- Energia Hidrelétrica

\footnotetext{
${ }^{19}$ Recentemente, em função do desempenho econômico em retração, aumento acentuado nos preços e tarifas de energia, revisaram-se as taxas de crescimento do consumo para 3,3\% na média.
} 
- Termelétrica

- Fontes complementares (renováveis, PCH, biomassa e principalmente eólica)

A hidroeletricidade é o recurso mais abundante no Brasil e determinante para segurar o aumento custo da energia, pois é a fonte mais barata de todas. A existência de reservatórios é fundamental para outras fontes de energia, pois além de regularizar as vazões, integram ao sistema fontes sazonais ou intermitentes como biomassa e eólica, que funcionam como infraestrutura virtual de armazenamento e tem sinergia com usinas térmicas, contribuindo com a redução de custos de combustível. Mesmo que haja abundância de oferta hidrelétrica, a expansão de mínimo custo para o consumidor é um "mix" de usinas hidrelétricas e termelétricas. A razão é que estas usinas têm atributos complementares, as térmicas contribuem para a segurança operativa nas hidrologias desfavoráveis e as hídricas permitem reduzir os custos operativos das térmicas nas hidrologias favoráveis.

O atributo adicional das termelétricas é a despachabilidade (capacidade de gerar quando necessário), o que será mais importante na presença de renováveis.

Já as fontes alternativas têm potencial significativo para nova capacidade, menor tempo de construção, o que é importante devido à incerteza no crescimento da demanda. Podemos definir que a hidrelétrica é a âncora e as demais podem fazer os ajustes. Tem-se ainda o atributo de complementaridade entre bioeletricidade, energia eólica e hidrelétricas, que será analisado adiante neste trabalho. Por fim, os reservatórios das hidrelétricas e a rede de transmissão são usados para modular a produção de energia da biomassa e eólica.

Os desafios para a estratégia de expansão acima são:

- Hidrelétricas: licenciamento ambiental

- Térmicas a gás: restrição ao suprimento e infraestrutura de gás e condições adversas dos contratos de suprimento de gás natural fornecidos pela Petrobrás inibem investidores, falta uma política de gás natural para o país

- Renováveis:

- PCHs: bons projetos cada vez mais difíceis, dificuldades crescentes no processo de licenciamento ambiental e novas regulamentações MME/ANEEL (revisão da Garantia Física e exclusão do MRE) afastam investidores. 
- Cogeração a biomassa da cana-de-açúcar: a bioeletricidade deveria ser a fonte mais promissora ("alavanca" o crescimento da produção de etanol) mas até o momento o montante contratado foi abaixo do esperado por dificuldades com a conexão com a rede e de preços de energia. Há outras fontes de biomassa promissoras tais como o capim-elefante e resíduos orgânicos.

- Estes desafios deixaram a energia eólica como a única fonte renovável capaz de disputar os leilões em volume e preço significativo, tendo uma grande janela de oportunidade. O que pode ser explicado pelo grau de maturidade atingido pela tecnologia das centrais eólicas, bem como pelos benefícios fiscais concedidos e nacionalização de uma parcela dos componentes. Resta apenas superar as questões de conexão ao sistema de transmissão/distribuição, que caracterizam o único grande entrave à disponibilização da fonte ao sistema.

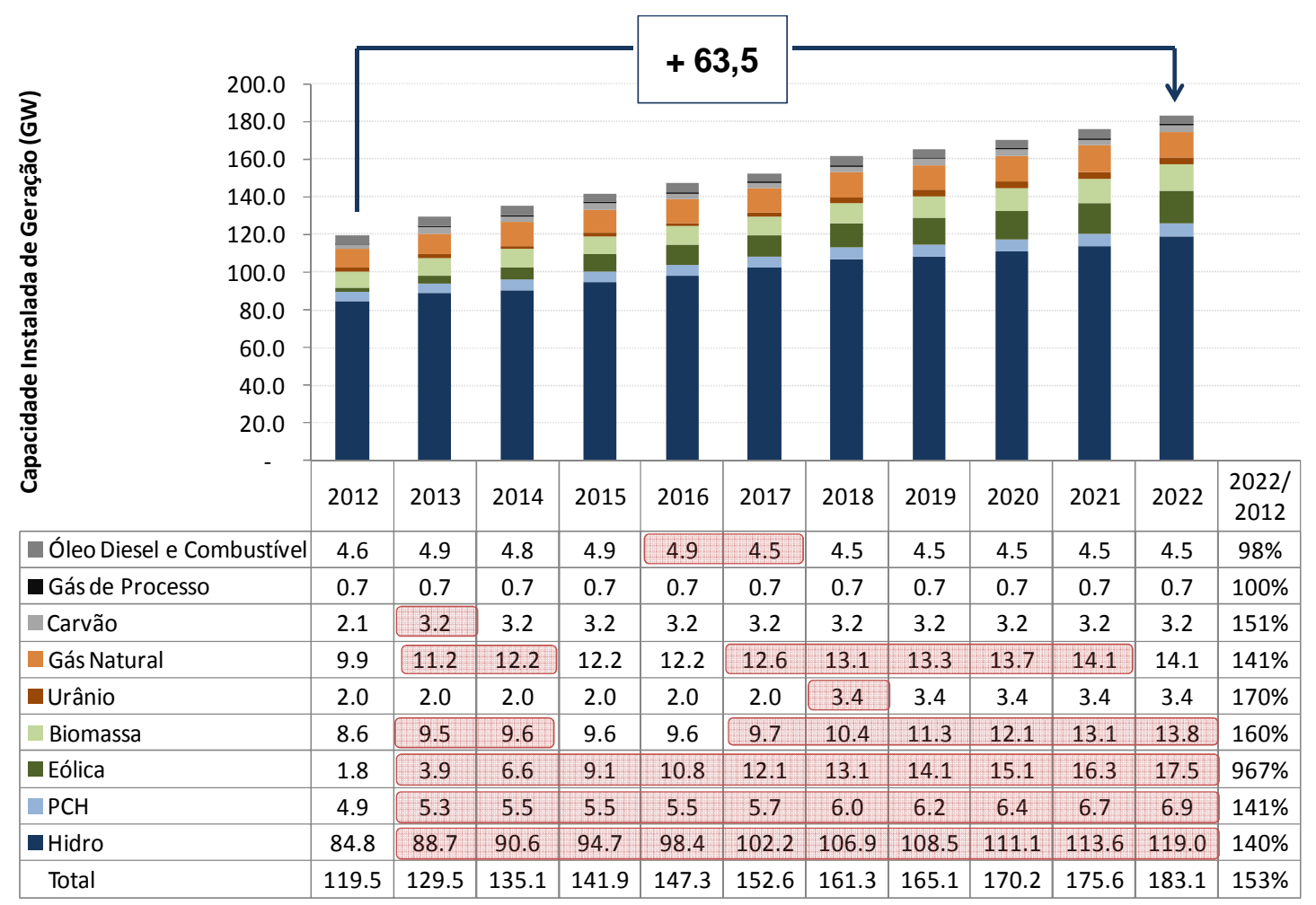

Figura 8 - Expansão da oferta de geração (Fonte: Confecção própria e Dados: PDE 2022-MME) 


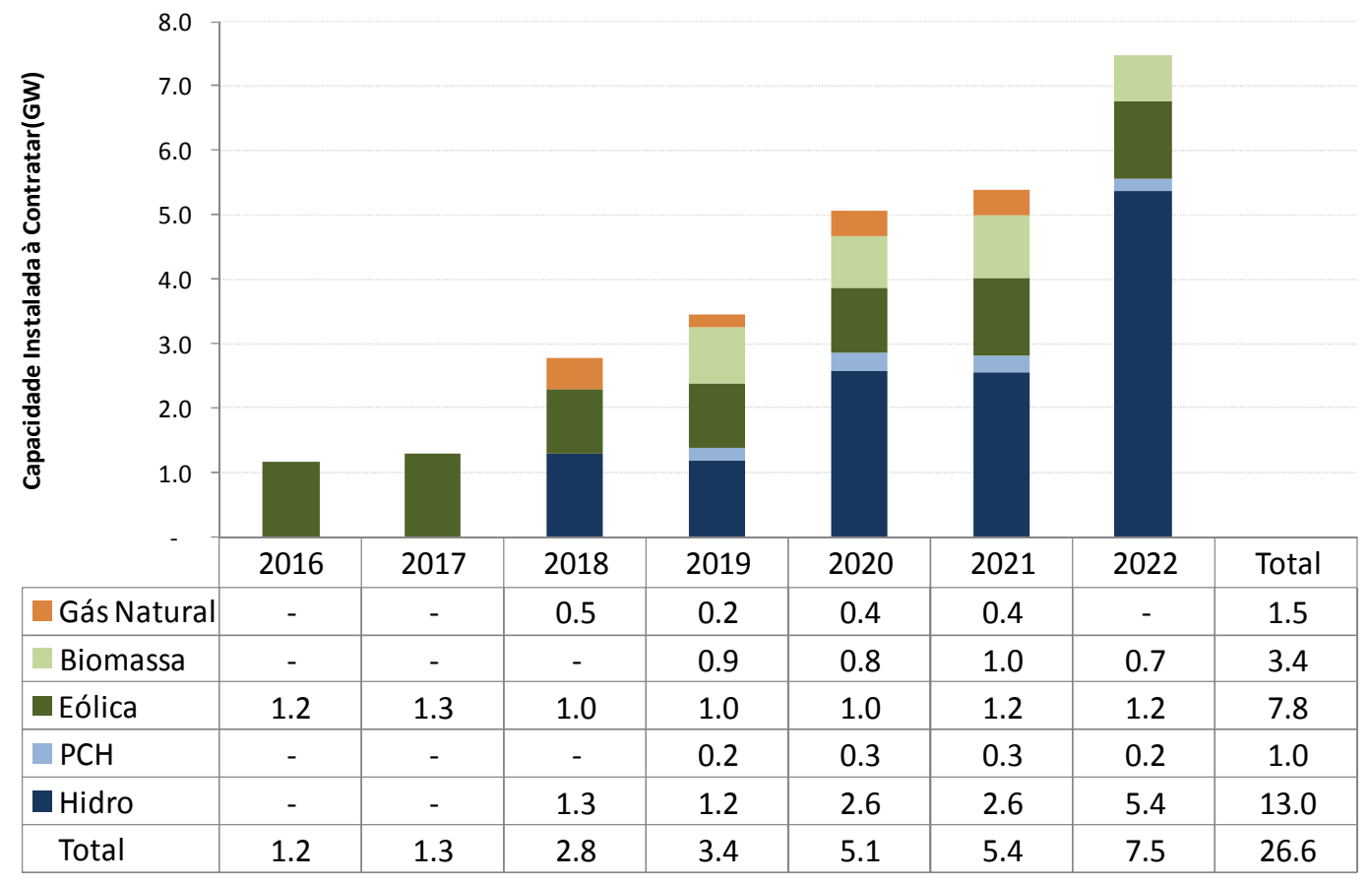

Figura 9 - Expansão da oferta a contratar (Fonte: Confecção própria e Dados: PDE 2022-MME)

\section{A expansão da energia renovável não convencional no ACL}

A expansão do mercado das fontes renováveis não convencionais através do ACL pode ser analisada por pontos de vista distintos. Do ponto de vista do empreendedor, um dos maiores desafios relacionados à expansão via ambiente livre diz respeito à obtenção de financiamento. A atual dinâmica do setor elétrico, produto das constantes mudanças regulatórias, tem imputado muitas incertezas a todo o mercado, tornado menos atrativa a assinatura de contratos de longo prazo, que são o principal instrumento para obtenção de crédito junto às entidades financiadoras. Em geral, quando os empreendimentos não são objetos de leilões regulados, estes têm, necessariamente, um grande grupo adquirindo contratos de longo prazo ou fazem parte de algum programa de desenvolvimento do próprio governo Federal ou Estadual.

Dentre as mudanças que afetaram a dinâmica do mercado, uma das que trouxe maior impacto aos geradores foi a Resolução CNPE $n^{\circ}$ 03/2013, que definiu a adoção de mecanismos de aversão a risco nos modelos de despacho e preço utilizados pelo ONS e CCEE, aumentando o valor do PLD e, consequentemente, o referencial para negociações de energia no curto e médio prazo. 
Um problema que até meados de 2013 era exclusivo da expansão via ACL é a questão dos atrasos nas Instalações Compartilhadas de Geração (ICGs) e linhas de transmissão para dar escoamento à energia produzida pelas usinas eólicas, em especial na região Nordeste do país. Essa questão, conforme mencionado em 2.4.4, passou a ser pré-requisito também para os parques que negociam via leilões regulados a partir de 2013. Estudos da expansão da Rede Básica desenvolvidos pela EPE apontam diversos reforços necessários para tornar o sistema de transmissão mais robusto e capaz de atender ao potencial de cada região. Entretanto, a licitação de cada trecho deve passar por processos de audiência pública para publicação do edital e posterior execução do leilão. Muitas vezes, a velocidade desses processos não está em linha com a real necessidade de expansão do potencial de geração.

Do ponto de vista dos consumidores, dentre as mudanças regulatórias que culminaram na atual conjuntura e que vêm dificultando a expansão do mercado, podemos destacar a Medida Provisória 579 de 2012, na qual parte da energia que seria destinada ao ACL foi realocada ao ACR através do regime de Cotas, reduzindo a oferta energética. Adicionalmente, a MP 579 alterou o prazo de retorno do consumidor especial para o ambiente cativo de 180 dias para 5 anos, assim como já era feito para o consumidor livre.

Outra medida que resultou em grande instabilidade para todo o setor, afetando não apenas uma classe de agentes, mas todo o mercado, são as Portarias 455/2012 e 185/2013, que tratam do registro ex-ante e em base semanal da energia e que têm causado uma enorme incerteza frente à possibilidade de os contratos vigentes precisarem passar por um processo de renegociação para se adequarem aos modelos de contratos propostos, o que reflete em instabilidade jurídica ao Setor.

Entretanto, é possível destacar a evolução da fonte eólica também no ACL, principalmente devido à competitividade que esta vem apresentando desde os leilões de energia nova de 2011. De acordo com dados do BNDES (59), cerca de 700MW de energia dessa fonte foram contratados recentemente no ACL pelas empresas Renova, Tractebel e CPFL Renováveis, o que reforça a questão da presença de grandes grupos para darem sustentação a essa evolução. Algumas das vantagens que os grandes grupos possuem em relação aos demais investidores está na assunção dos riscos decorrentes do perfil sazonal da geração frente às flutuações de preço e de instabilidades regulatórias. 
Conforme mencionado anteriormente, tanto a energia eólica quanto a biomassa negociadas nos leilões regulados são apuradas em base anual, ficando a cargo das distribuidoras as exposições mensais ao mercado Spot. Quando se trata de negociação bilateral no ACL, uma das partes deve assumir o risco de exposição, arcando com os custos e riscos decorrentes das já mencionadas flutuações de preço de curto prazo e de geração. Portanto, vendedores que possuam formas de mitigação das exposições apresentam uma vantagem econômica em relação aos demais, podendo ofertar um produto livre de risco à parte compradora, sem a necessidade de um grande grupo que assuma tais riscos. Uma das formas de se conseguir essa mitigação é através da diversificação do portfólio com fontes complementares entre si, fornecendo um mecanismo de proteção contratual, ou hedge dentro do próprio portfólio do agente. Esses mecanismos são o objeto de estudo do presente trabalho.

Até junho de 2009, o governo federal havia zerado o imposto sobre a importação de aerogeradores, para facilitar o desenvolvimento da fonte no país, dada a existência de apenas uma empresa fabricante instalada em território nacional. A partir de então, esse incentivo foi extinto para impulsionar o desenvolvimento da cadeia produtiva nacional. Adicionalmente, o Ministério da Fazenda aprovou a isenção permanente do Imposto sobre Produtos Industrializados (IPI) para aerogeradores, o que representava cerca de $7,5 \%$ do valor do equipamento.

O Regime Especial de Incentivos para o Desenvolvimento da Infraestrutura (REIDI) reduziu para zero a cobrança de PIS-Cofins para toda a infraestrutura, sendo o segmento de geração de energia eólica um dos beneficiários mais importantes (13). Recentemente, a Portaria MME $n^{\circ}$ 310, de 12 de setembro de 2013, determina que os benefícios do regime serão estendidos à usinas do ACL. Os benefícios do REIDI podem representar até 10\% dos custos de construção dos empreendimentos (14).

Ainda de acordo com (13), outra possibilidade para as pequenas usinas de expansão do mercado é através do chamado "net metering" para exploração usinas de pequeno porte na geração distribuída, recentemente regulamentado pela ANEEL através da Resolução 482, de abril de 2012. O "net metering" consiste em regular a troca de energia entre o consumidor e a concessionária de distribuição local, onde créditos são acumulados com as concessionárias quando há excedentes de energia e os débitos são acumulados quando o consumo local supera a geração. $\mathrm{O}$ faturamento da conta de energia para o consumidor final considera o balanço entre os 
créditos e os débitos. Mais recentemente no início de 2015 o governo apresentou propostas de incentivo à geração distribuída.

\subsection{O montante de energia a ser comercializado}

Uma vez definido o montante de energia contratada (cada empresa geradora pode comercializar até $100 \%$ da energia assegurada que lhe for atribuída, não havendo restrição de percentual mínimo contratado), o gerador será responsável pelo suprimento deste montante, dispondo do adicional de geração conforme critério de rateio do MRE, para venda no mercado de curto prazo.

Caso um agente contrate bilateralmente $100 \%$ de sua energia assegurada, este não dispõe de flexibilidade para negociar energia no curto prazo, fazendo com que sua participação nesse mercado seja restrita à eventual geração de energia secundária (alocação acima da energia assegurada, devida a afluência melhor do que a esperada).

Por outro lado, um agente possui maior flexibilidade se não comprometer em contrato uma parcela de energia. Esta flexibilidade permite ao agente vender a energia sem contrato no mercado de curto prazo, minimizando, como resultado da restrição associada ao patamar adotado para o risco máximo de exposição financeira, o risco de necessitar adquirir a preços elevados uma complementação de parte do seu contrato, se a energia que lhe foi alocada no momento da entrega for menor do que o total de sua energia assegurada.

A restrição do risco tem como contrapartida a possibilidade de venda da parcela descontratada a preços muito baixos em período de grande disponibilidade energética, o que reduz a receita esperada.

Em face do exposto, é de se esperar que o preço de venda de energia, no mercado de contratos de curto prazo, tenha grande aderência com a expectativa dos preços do mercado de curto prazo (preços Spot ou PLD).

\subsection{Características da Comercialização de Energia - Modelagem da Receita de Comercialização}

A realização de contratos "por quantidade" é considerada como uma ferramenta de gestão de risco de energia. O risco de fornecimento de energia está nas mãos do produtor, que não é 
obrigado a produzir fisicamente o valor contratado, mas deve liquidar no mercado à vista a diferença entre a energia produzida e contratada. Neste sentido, o mercado de curto prazo passa a ser uma câmara de compensação em que a falta de energia e os excedentes são negociados a preço spot e os contratos são bons mecanismos para proteger da volatilidade do preço spot. É o que se denomina de um "Mercado de Diferenças".

A receita para cada período $\mathrm{t}$ e cenário s de uma empresa de geração ou comercializadora vendendo $\mathrm{E}$ (MW Médio) em um contrato ao preço $\mathrm{P}(\mathrm{R} \$ / \mathrm{MWh})$ pode ser obtida pela seguinte expressão (desprezando custos de produção):

$R_{t, s}=P \cdot E \cdot h_{t}+\left(G_{t, s}-E \cdot h_{t}\right) \cdot P L D_{t, s} p / t=1, \ldots, T$ e $s=1, \ldots$,

onde:

ht é o número de horas no período t, Gts é a geração, ou energia alocada pelo MRE Mecanismo de Realocação de Energia (MWh), em cada período t e cenário s e, PLDts é o preço spot $(\mathrm{R} \$ / \mathrm{MWh})$ no período t e cenário de despacho s.

$\mathrm{Na}$ expressão (9) existem dois tipos de receitas: (i) o pagamento fixo pelo montante contratado (determinístico), pago pelos consumidores, e (ii) variável de contabilização no mercado de diferenças (spot), que é estocástica (ou seja, depende de cenários do preço spot futuro e produção de energia) e pode assumir valores negativos em cenários de escassez de energia, onde a geração é inferior à energia vendida.

A parcela da receita advinda do contrato "flat", denominada Receita Fixa, é proveniente do montante de garantia física do portfólio alocada ao contrato, valorada ao preço do contrato, por todo o período de sua vigência. Esse montante pode variar de acordo com o número de fontes utilizadas na simulação e com o percentual da garantia física disponível que foi alocada, resultante do processo de otimização da receita. A soma da Receita Fixa com o resultado do Custo de Exposição ao MCP ou Custo Spot, em cada período do histórico, resulta na Receita Líquida Mensal. A Receita Total esperada é, portanto, o somatório das Receitas Líquidas Mensais de todo o horizonte de estudo.

Portanto, um aspecto fundamental para modelar o comportamento futuro dos contratos é a previsão de preços spot futuros. Na presença de um mercado spot competitivo, os preços podem ser calculados através de modelos estatísticos, tais como sazonais auto-regressivos, em que os 
desvios relevantes dependerão das características específicas do mercado. No entanto, na presença de um sistema de programação e despacho centralizado - como no caso do Brasil cenários de preços spot futuros podem ser gerados através dos mesmos modelos de previsão de despacho. Estes modelos simulam o funcionamento ótimo do sistema em um horizonte de tempo determinado considerando incertezas nas afluências e, assim, permitindo a produção de cenários de preços spot de energia futuros (com base nos custos marginais).

Como a atividade de comercialização de energia é baseada na livre concorrência, para a atuação no mercado de livre negociação com êxito na realização de contratos de compra e venda com outros agentes, são necessárias vantagens competitivas, dentre as quais podemos destacar:

$\square$ Vasto portfólio de produtos a ser oferecido aos clientes

- Agilidade na tomada de decisão de tal forma a tirar o máximo proveito tanto em oportunidade de negócios quanto de mitigação de risco

口 Avaliação do risco de cada transação, bem como de seu portfólio, quanto à volatilidade futura dos preços.

Avaliação de outros tipos de risco, tais como crédito das contrapartes, operacionais, regulatórios, etc.

\subsection{Aspectos a serem considerados na elaboração da estratégia}

Com os importantes conceitos apresentados nas seções precedentes, pode-se seguir com a apresentação dos passos para elaboração da estratégia de comercialização de energia. Uma etapa importante é o levantamento dos riscos e oportunidades inerentes a cada um dos ambientes de contratação.

Do ponto de vista qualitativo, pode-se dizer que o ACR tem como característica a possibilidade de venda de blocos maiores de energia, com condições contratuais previamente conhecidas e inflexíveis, sujeito a um risco de crédito médio das distribuidoras do sistema interligado, além de concorrer exclusivamente por preço.

Avaliações quantitativas envolvem conhecer quanto e em quais leilões as distribuidoras estão dispostas e são incentivadas a comprar a energia para o atendimento de seus mercados. Por outro lado, o ACL tem como característica a venda de quantidades menores de energia, porém com 
cláusulas contratuais livremente negociadas entre as partes, com risco de crédito melhor e seletivo, podendo o vendedor oferecer outras vantagens competitivas como agilidade na negociação, flexibilidade de prazos e outros serviços agregados.

Também são necessárias avaliações quantitativas como o volume potencial do mercado e a expectativa de tarifa dos consumidores cativos das distribuidoras, definindo a atratividade da migração dos consumidores potencialmente livres para este ambiente, estimado a partir do preço médio de compra de energia no ACR. Intuitivamente, pode-se concluir que a estratégia mais ponderada envolve um equilíbrio na alocação dos montantes de energia a contratar em ambos os ambientes de comercialização.

No que tange à energia de fontes alternativas, pode-se citar a possibilidade de venda flexibilizada aos consumidores livres, sendo permitida a união de consumidores com a finalidade de atender a exigência de demanda mínima contratada, ampliando a demanda potencial do mercado livre. Somado a isto tem-se a realização de leilões com o objetivo de promover a expansão de fontes alternativas de energia possibilitando a contratação direta para as concessionárias de distribuição.

Tudo isso tem contribuído para o aumento da concorrência no momento em que o investidor escolhe qual é a melhor oportunidade de venda. Inicialmente o PROINFA se mostrou muito interessante a todas as fontes (PCH, biomassa e eólica).

Outra questão que também influencia na decisão de onde o gerador pretende negociar a energia proveniente de suas usinas, são os direitos aos créditos de carbono que podem ser utilizados no Mecanismo de Desenvolvimento Limpo - MDL. Segundo o Decreto $n^{\circ}$ 5.882/06, para as usinas participantes do PROINFA, os recursos advindos das atividades relacionadas ao MDL, ou outros mercados de carbono, serão destinados à redução dos custos do PROINFA, rateados entre todas as classes de consumidores, visando a modicidade tarifária. Nas outras formas de comercialização, os créditos de carbono ficam com o proprietário da usina.

As alterações promovidas tiveram como principal objetivo aumentar os prováveis compradores de usinas de fontes alternativas, que por sua vez devem atrair investimentos de capital privado na expansão da geração. Portanto este mercado deve ser observado nos próximos anos, pois apresenta grande capacidade de crescimento. 
No entanto, é de reconhecida dificuldade definir os percentuais de contratação em cada ambiente - trata-se de uma decisão complexa envolvendo diversas variáveis. Também é evidente que se trata de um processo dinâmico, onde a cada instante deve-se reavaliar o percentual de energia destinado a cada mercado, livre ou regulado. Inobstante as dificuldades inerentes ao processo de estabelecimento de estratégias comerciais, ao contrário das Distribuidoras, que se organizam cooperativamente sob uma única associação (ABRADEE), os agentes Geradores têm grande dificuldade de coordenarem seus interesses junto aos entes governamentais, fato demonstrado pela existência de múltiplas associações de classe (ABRAGE, APINE, ABRAGET, ABRAGEL, ABRAPCH, ABEEOLICA, ABRAGEF, APMPE, etc.).

Por fim, é importante conhecer o balanço entre oferta e demanda de energia elétrica presente e futuro, de forma a se definir as tendências do mercado, impactando diretamente no preço de venda.

Neste processo todo, um grande número de ferramentas de previsão de preços e de condições de despacho das usinas, de simulação das regras de mercado e dos comportamentos dos agentes, além de modelos econômico-financeiros, são utilizados. Trata-se de toda uma cadeia interdependente em que cada elo representa papel relevante no desenho da estratégia. 


\section{ENERGIA RENOVÁVEL NÃO-CONVENCIONAL - SAZONALIDADE E INTERMITÊNCIA NA GERAÇÃO}

A geração de energia eólica está suscetível a bruscas interrupções em virtude do efeito denominado "calmaria", durante o qual os ventos cessam ou têm velocidade insuficiente para acionar as turbinas. Em países com elevada participação da fonte eólica e reduzida participação hidrelétrica, tal característica requer reforços nos sistemas de transmissão e o acionamento de térmicas de prontidão, que precisam se manter "prontas" para a entrada em operação em alguns minutos e que, para isso, mantém suas caldeiras aquecidas através da queima de uma parcela de combustíveis fósseis. Esse não é o caso ainda do sistema brasileiro, mas convém frisar que particularmente para a região Nordeste, já se visualiza a eventual sobremotorização de hidrelétricas existentes como, por exemplo, Itaparica e Xingó, ao mesmo tempo em que pode ser necessário reforço na geração térmica. Dessa forma, analisar apenas o preço de venda em um determinado certame é algo muito superficial, pois cada fonte possui sua particularidade em termos de custos e benefícios para o Sistema.

Apesar da volatilidade, as usinas eólicas, principalmente, têm obtido êxito nos leilões de energia, uma vez que os contratos de comercialização de energia elétrica do ACR transferem os riscos da volatilidade da geração e exposição financeira ao mercado de curto prazo na apuração mensal para os consumidores finais, por definição do poder concedente. Não obstante, o processo de leilão tem resultado em concentração de empreendimentos eólicos em alguns Estados da região Nordeste, aumentando o risco da geração. Apesar dessa concentração, não existe previsão no marco regulatório, tampouco o governo demonstra interesse em viabilizar leilões regionais no ACR.

Por sua vez, no Ambiente de Contratação Livre (ACL) os consumidores livres compram a energia de fornecimento por meio de negociações diretas com os vendedores. Apesar dos preços de energia no ACL serem superiores aos preços dos leilões regulados, em razão do benefício do desconto de $50 \%$ na tarifa de uso do sistema de distribuição/transmissão, poucos empreendimentos eólicos tinham sido desenvolvidos nesse ambiente, em razão dos riscos de exposição financeira no curto prazo. De acordo com as regras de comercialização, a diferença entre a quantidade de energia produzida pelo gerador eólico e o valor do contrato de venda é liquidada ao preço do curto prazo (PLD). 
De modo que, quando a energia gerada é maior que o montante contratado, a exposição financeira ao curto prazo é positiva; no entanto, quando a geração de energia é inferior ao montante contratado, a exposição financeira é negativa. Estimar o valor da exposição financeira do gerador eólico não é tarefa simples, uma vez que depende de duas variáveis aleatórias, a geração de energia e o preço do mercado de curto prazo (PLD).

Desde 2007, a partir do primeiro Leilão Regulado exclusivo para fontes alternativas, o mercado brasileiro vem criando condições para a introdução das fontes alternativas em percentual significativo da matriz energética nacional, através de incentivos e da criação de um mercado exclusivo para tais fontes. Entretanto, devido a fatores econômicos externos e a políticas de redução tarifária, os baixos preços praticados nos últimos leilões regulados deixaram muito estreita a margem de negociação para algumas empresas, inviabilizando a construção de novos empreendimentos baseados apenas na receita esperada dos PPAs desses leilões. Isso significa que investidores passaram a enxergar no mercado livre uma alternativa para viabilizar seus projetos, com preços mais atrativos e oportunidades de negócio mais flexíveis.

\subsection{Volatilidade da Geração Eólica}

O Brasil possui grande potencial em energia eólica, sendo a disponibilidade do recurso maior no período de junho a dezembro, coincidindo com os meses de menor intensidade de chuvas. Isso coloca o vento como uma potencial fonte suplementar de energia gerada por hidrelétricas.

Fatores econômicos e políticos estão associados à disseminação dessa energia no país, que tem atingido crescimento muito relevante em sua participação na Matriz Energética. Entretanto, as EOL possuem uma característica intermitente, cuja geração pode cessar rapidamente e com grau de previsibilidade limitado, causando sérios distúrbios nos sistemas de distribuição. Para garantir o balanço energético e o atendimento da carga, a energia eólica deve contar com sistemas ancilares, os quais dão maior confiabilidade ao abastecimento energético de uma região, tais como reserva de prontidão e reserva girante (15) (5).

A inserção de energia eólica em matrizes energéticas tem sido objeto de estudo em diversos países e entidades ligadas a pesquisa e desenvolvimento tecnológico. Nesse contexto, foi publicado por (16) um artigo que propunha uma adaptação do modelo brasileiro de mitigação de risco hidrológico, o MRE, para usinas eólicas no mercado spot Britânico, como mecanismo de 
mitigação de exposição de parques que negociam energia isoladamente. $\mathrm{O}$ artigo investigou como a produção energética de usinas eólicas em um sistema unificado pode fornecer hedge às operações por meio de compensações de sobras e déficits energéticos entre usinas, de maneira similar ao que acontece no sistema brasileiro para as usinas hidrelétricas. Tal troca permite otimizar os níveis de contratação das empresas envolvidas, pois mitiga os riscos de exposição que ocorrem em virtude das variações na produção energética. Tal reconhecimento reflete a necessidade de adaptação da fonte eólica à realidade de mercados de energia, inclusive de países onde o setor elétrico já está consolidado.

Uma importante contribuição sob essa ótica também foi feita em (17), analisando dois casos específicos, onde um é a introdução de um MRE apenas entre usinas eólicas e outro é um MRE entre as hidráulicas e as eólicas. O estudo mostra que o benefício existe em ambos os casos, mas que é maior para as eólicas quando a fonte hidráulica é introduzida. Entretanto, o benefício envolvendo as duas fontes é válido somente se a proporção da capacidade instalada da fonte eólica em relação à fonte hidráulica for significativa, situação essa ainda muito longe da realidade do país.

Outro ponto de destaque do trabalho é a importância da inserção de fatores de risco ao ser calculada a Garantia Física dos empreendimentos eólicos, uma vez que a geração média não é capaz de capturar os eventos extremos de geração (tanto positivos quanto negativos), que são fundamentais para uma correta análise de ganhos em termos energéticos e financeiros que um MRE poderia trazer. Finalmente, é importante destacar que a qualidade dos dados de vento utilizada na elaboração do artigo contribuiu significativamente para os bons resultados obtidos.

A geração de energia eólica, assim como a hidráulica, depende de fenômenos da natureza que possuem comportamento estocástico, o que torna muito difícil qualquer determinação de um padrão de comportamento sazonal, a menos que se tenham dados históricos em quantidade e qualidade suficientes. Adicionalmente, devido ao curto período em que se dispõe de coleta de dados precisos para a energia eólica, tais como velocidade do vento, temperatura e pressão do ar, simulações estocásticas para geração de séries sintéticas de vento ainda não foram integradas ao atual modelo de despacho utilizado oficialmente no País, o Newave, de maneira semelhante com o que já é feito para as séries hidrológicas. No caso de simulação com um sistema independente, deve-se determinar qual a melhor metodologia para obtenção de séries sintéticas de vento. As 
séries de ventos, cruzadas com a curva de potência de um modelo específico de turbina adotado como padrão, irão gerar os dados de geração eólica necessários ao estudo.

Em (18), a geração de cenários de vento foi feita através de simulações utilizando-se o método de Monte Carlo para a obtenção de uma curva de distribuição de probabilidades, baseando-se em dados de vento obtidos o modelo de mesoescala WRF3.3 (Weather Research and Forecasting Model), do NCEP (National Center for Environmental Prediction), correlacionado com os dados históricos obtidos de observações na região de estudo do Brasil. A metodologia resultou em dados que puderam ser usados com a série histórica de vento que, cruzada com a curva de produção de uma turbina padrão, fornece os cenários de geração.

Uma abordagem semelhante foi realizada em (3), onde os dados foram obtidos de dois modelos, o NOAA (National Oceanic and Atmospheric Administration) e o Vestas Mesoescala Modelo 1. Em ambos os casos, a metodologia resultou em dados que puderam ser considerados com a série histórica de vento, a qual, cruzada com a curva de produção de uma turbina padrão, pode gerar os cenários.

O vento é o resultado da transformação da energia térmica, decorrente da irradiação solar, em energia cinética, que provoca o deslocamento de massas de ar. Uma das características do vento é sua intermitência. Pequenas variações na velocidade do vento provocam grandes variações na potência eólica, uma vez que a potência é proporcional ao cubo da velocidade.

Há inúmeras funções de densidade de probabilidade que podem ser utilizadas para representar o comportamento da velocidade do vento. De acordo com Fadigas (2011), a distribuição de Weibull consegue abranger o maior número de padrão eólico, uma vez que incorpora a distribuição exponencial e a distribuição de Rayleigh, além de fornecer boa aproximação a distribuição normal.

A Equação 10 representa a função de densidade de probabilidade de Weibull. Para conhecer o comportamento da velocidade do vento é necessário estimar os fatores $\mathrm{k}$ (denominado de fator de forma) e $\Lambda$ (denominado de fator de escala), que são dependentes da média e do desvio padrão. 
$f(x ; k, \Lambda)=\frac{k}{\Lambda}\left(\frac{x}{\Lambda}\right)^{k-1} e^{-\left(\frac{x}{\kappa}\right)^{k}}$

$k=\left(\frac{\sigma_{V}}{\bar{V}}\right)^{-1.086} \quad \frac{\lambda}{\bar{V}}=(0.568+0.433 / k)^{\frac{-1}{k}}$

A Figura 10 apresenta a função densidade de probabilidade de Weibull para diversos fatores de forma (fator k), demonstrando que para $\mathrm{k}$ igual a 1, a função Weibull é o caso particular da função exponecial, para k igual a 2, a função Weibull é o caso particular da função de distribuição Rayleigh e para k igual a 5, a função Weibull fornece uma boa aproximação da função densidade de probabilidade normal. $\mathrm{O}$ fator de forma $(\mathrm{k})$ é inversamente proporcional ao desvio padrão. Assim, quanto menor a volatilidade da velocidade, menor o desvio padrão, menor a intensidade de turbulência, os valores de velocidade estarão mais concentrados em torno da média e maior o fator de forma (se aproxima mais de uma função de distribuição de probabilidade normal)

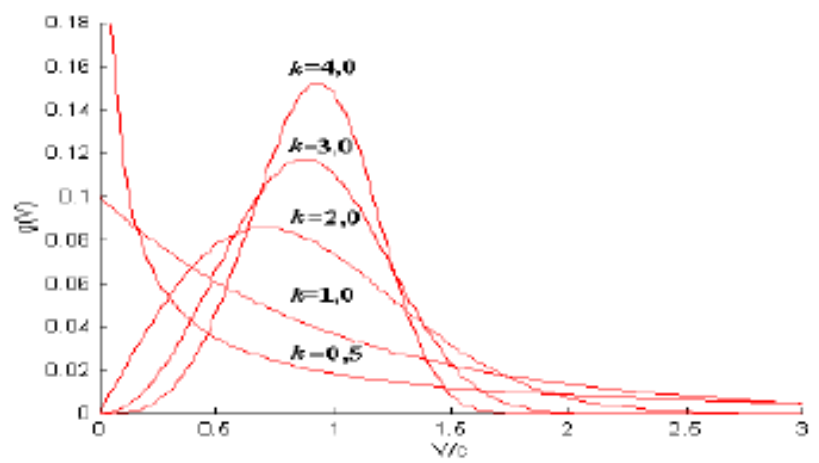

Figura 10 - Influência do parâmetro ke na curva de distribuição de Weibull (Fonte: Fadigas (2011))

O fator de escala $(\Lambda)$ é diretamente proporcional à velocidade média do vento. Dessa forma, à medida que o fator $\Lambda$ aumenta, a função de distribuição de probabilidade tende a atingir valores maiores de velocidade do vento, tornando a função menos concentrada em torno do valor médio. A Figura 11 ilustra esse fenômeno. 


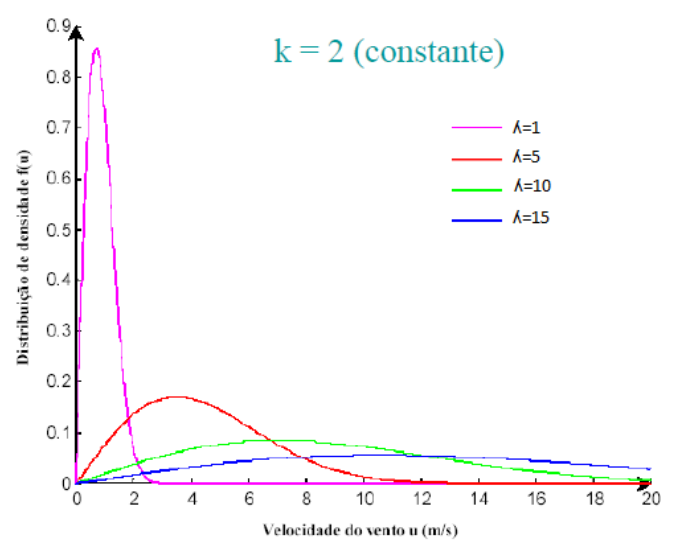

Figura 11 - Comportamento da função de distribuição de Weibull para diversos valores de $\complement$ (Fonte: Fadigas (2011))

A geração de energia eólica depende da função densidade de probabilidade do vento e da curva de potência de uma turbina eólica, fornecida pelo fabricante.

Segundo Carvalho (2003), a curva de potência é caracterizada pela velocidade de entrada, velocidade nominal e velocidade de corte do vento. A Figura 12 apresenta uma curva típica de potência de uma turbina eólica, retirada de Fadigas (2011).

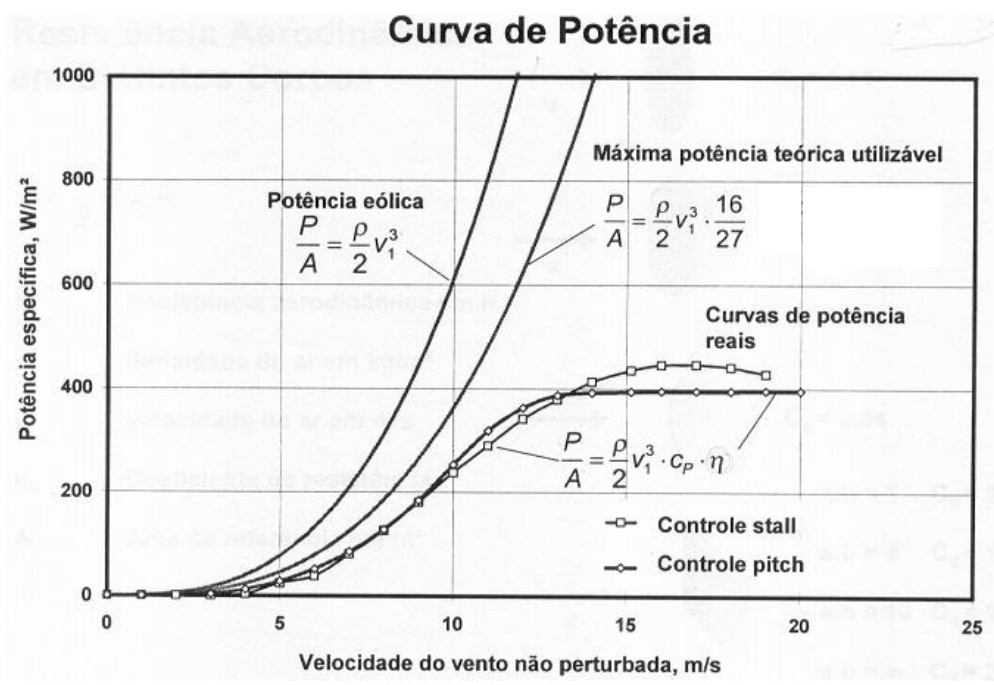

Figura 12 - Curva de Potência da Turbina Eólica (Fonte: Fadigas (2011))

A quantidade de energia gerada é estimada pela intersecção da curva de potência do aerogerador com a curva de densidade de probabilidade de Weibull para a velocidade do vento.

Tais usinas são representadas no modelo de previsão de despacho como despachadas na base, respeitando a disponibilidade média mensal do recurso. Entretanto esse procedimento é bastante impreciso na prática e conduz a resultados extremamente otimistas, pois modela cada planta eólica pelo seu perfil médio de geração (para cada mês a produção acaba sendo sempre a mesma), 
desconsiderando as incertezas intrínsecas da geração eólica, que se rebatem em gerações bastante distintas da média em vários períodos de tempo, para cada planta.

A variabilidade e a impossibilidade de armazenar o vento como ocorre com a água nos reservatórios das usinas, resulta em uma geração de energia variável e intermitente. No entanto, em razão das dimensões geográficas do Brasil, é possível que em determinados momentos, subsista vento bom para geração de energia em certos locais, e em outros, não. Em outras palavras, para um determinado conjunto de usinas eólicas, geograficamente dispersas, é possível reduzir a volatilidade da geração individual, face às compensações existentes entre as mesmas.

\subsection{Volatilidade da Geração a Biomassa}

O Brasil é um produtor e exportador de etanol, oriundo da cana. O bagaço de cana é utilizado como combustível para produzir eletricidade, por meio de uma turbina a vapor. Isto faz com que o processo de produção de etanol seja auto-suficiente em termos de eletricidade. Uma vez que vários produtores estão instalando eficientes caldeiras de alta pressão, a quantidade de MWh produzido é maior do que o consumo da usina de etanol e este excedente de energia está sendo exportado à rede.

A central de cogeração que utiliza o bagaço de cana produz uma quantidade constante de energia durante o período de colheita, que, no sudeste do Brasil, ocorre de maio a novembro. Esta planta pode vender sua energia excedente por meio de um contrato de quantidade de longo ou médio prazo, mas ficará exposto no mercado spot durante os meses sem produção. A garantia física anual da planta é igual à sua produção anual total de energia em MW Médio. Como é produzido $100 \%$ de energia total durante sete dos doze meses (e não tem produção nos restantes cinco meses do ano), isso leva a uma GF equivalente a 48\% da sua capacidade disponível (produção de energia constante anual), considerando um fator de disponibilidade mensal de $90 \%$ da capacidade instalada. No caso de uma fábrica de $30 \mathrm{MW}$, a GF seria, então, 14,40 MWm.

Um aspecto interessante é que o período de safra da cana coincide com o período seco do sistema hídrico, consequentemente, os preços spot tendem a ser maiores neste período do que nos outros, levando a uma sinergia favorável: no exato período em que todas as hidrelétricas estão enfrentando uma baixa produção de energia, a cogeração a partir da cana está vendendo seu excedente de geração e recebendo uma remuneração elevada, pois os preços no mercado de 
curto prazo estão altos. Mas, apesar dessa vantagem, um resultado bem conhecido de comportamento de aversão ao risco na teoria da decisão diz que um agente é muito mais sensível às condições desfavoráveis do que às favoráveis, e uma vez que existem alguns períodos em que não há produção (de dezembro a abril), a exposição ao mercado spot durante este período pode vir a ser um componente da despesa impeditivo para qualquer investidor avesso ao risco individual, bastando ocorrer um início de ano seco, como em 2014 e 2015, por exemplo.

Por conseguinte, a consequência prática é que plantas de geração a biomassa são muito relutantes em assinar contratos de quantidade de energia ("flat") por causa do risco de ficar exposto durante os meses de entressafra.

No contexto do que vem ocorrendo desde 2012, com afluências abaixo da média histórica e níveis de armazenamento nada confortáveis, resultando em custos marginais no patamar de milhares de reais em pleno período úmido, culminaria com a insolvência financeira de um investidor neutro ao risco.

Esta fonte é significativamente afetada pelo mesmo fator climático que influencia a geração das PCHs e usinas eólicas: chuva. Períodos chuvosos favorecem a geração hidrelétrica, enquanto períodos de seca são caracterizados por maior incidência de vento. A biomassa pode ser afetada por ambos os eventos quando extremos, de chuva e de escassez. O excesso de chuva atrapalha a qualidade do bagaço, pois o excesso de água retido nas fibras da planta prejudica a capacidade calorífica das caldeiras. Por outro lado, a falta de chuva ou o atraso podem levar a uma baixa produção, quebra de safra ou deslocamento do período de geração.

Dada a relevância dessa fonte no mercado, há uma escassez de energia incentivada para negociação nos períodos onde não há geração. Em contrapartida, nos períodos de safra, há uma oferta muito elevada nos períodos coincidentes das safras das regiões Sudeste e Nordeste, o qual é compreendido entre abril e outubro. Tal característica afeta a liquidez do mercado de energia incentivada.

\subsection{Volatilidade da Geração das Usinas Hidráulicas}

Pequenas hidrelétricas no Brasil são plantas com capacidade instalada inferior a $30 \mathrm{MW}$ e área de reservatório menor do que $3 \mathrm{~km}^{2}$. As PCHs, por definição, não possuem reservatório de 
acumulação, operando em sistema a fio d'água. Isso significa que a geração dessas usinas está diretamente associada ao regime hidrológico da bacia hidrográfica da região, representado pelo valor de Energia Natural Afluente (ENA), o qual pode variar significativamente entre os períodos seco e úmido. Por isso, a quase totalidade das PCHs está no MRE, como forma de mitigação dos riscos hidrológicos, apesar de sua participação ser opcional. Dessa forma, uma maneira se representar a geração de uma PCH é aplicar à sua Garantia Física o perfil de geração das usinas que estão no MRE, o qual pode ser obtido através de arquivos de saída do modelo Newave. A possibilidade de fazer parte de um mecanismo de mitigação de riscos hidrológicos é uma vantagem estratégica. As PCHs possuem uma geração mais estável ao longo do dia e melhores condições de atendimento da ponta, há ainda a variabilidade de regime hidrológico no SIN. A garantia física é equivalente à média das afluências históricas, transformadas em geração de energia.

Por exemplo, a Figura 13 mostra a produção total de energia de uma PCH de 30 MW. A simulação da planta é realizada para o registro histórico de vazões e sua produção de energia média é de 19,5 MWm, que se torna sua GF. Nesta figura também é possível observar o efeito do período seco (maio-novembro) na geração da usina, bem como a variabilidade das afluências, o que resulta num padrão de produção muito volátil.

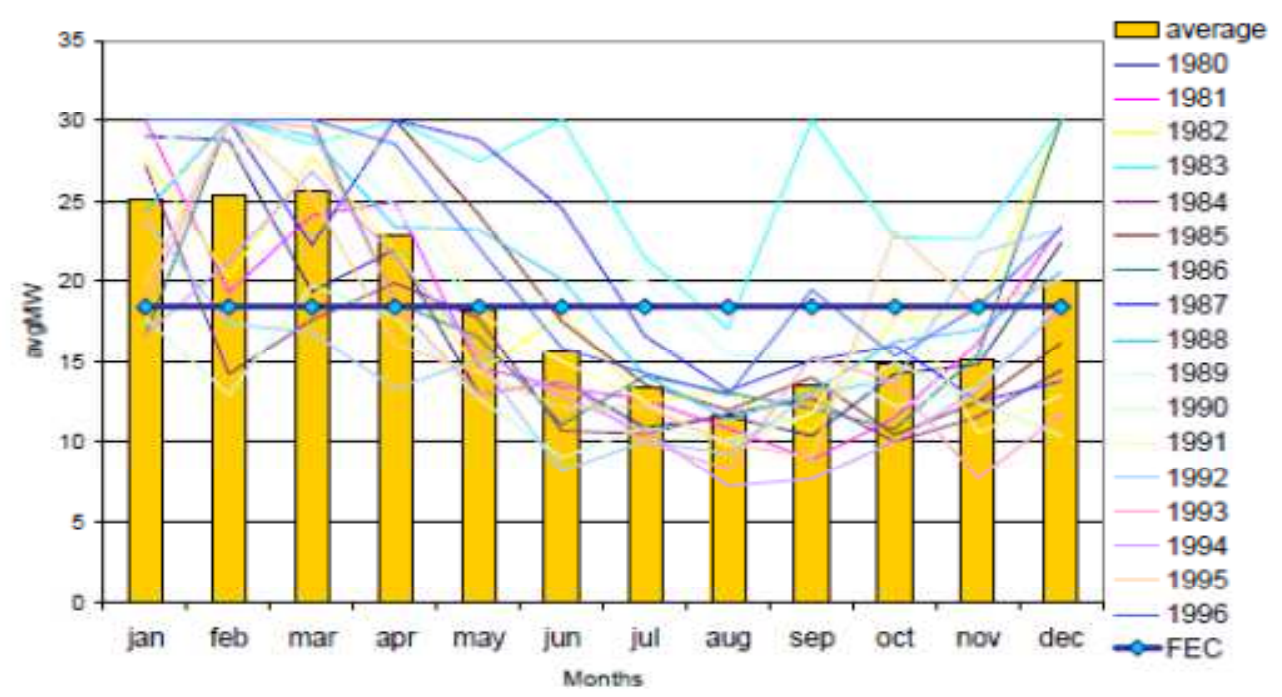

Figura 13 - Dados históricos de afluência convertidos em geração hidrelétrica para uma Pequena Central com $30 \mathrm{MW}$ de potência instalada. GF obtida por meio da média de geração estimada (19,5 MWm) Fonte (1).

Esses fatos, juntamente com a correlação negativa entre a produção hídrica e os preços no mercado de curto prazo, tornam arriscado para uma pequena hidrelétrica vender um contrato anual de energia firme. A razão é que as compras no mercado spot para compensar o desvio entre a produção física e o valor contratado pode ser frequente e ocorrer em cenários de preços 
elevados, introduzindo assim uma volatilidade indesejável, e um componente eventualmente negativo no fluxo de caixa do projeto. O fato de uma PCH pertencer ao Mecanismo de Realocação de Energia - MRE mitiga parte do risco de exposição ao curto prazo.

A permanência de uma PCH no MRE depende do atendimento a alguns parâmetros mínimos de geração, de acordo com a Resolução ANEEL n ${ }^{\circ}$ 409, de 2010. Caso uma PCH seja excluída do MRE ou, ainda, caso seja opção do empreendedor manter essa usina fora do mecanismo, o risco da produção energética dessa usina poderá ser muito elevado, assemelhando-se ao atual problema enfrentado pelas eólicas no ACL, podendo ser mitigado através de um portfólio complementar bastante diversificado ou, ainda, por contratos que absorvam o risco de exposição, através de mecanismos semelhantes aos empregados nos leilões regulados para contratos por disponibilidade.

\subsection{Complementaridade entre cogeração de cana, usinas eólicas e a produção de pequenas hidrelétricas - Revisão Bibliográfica}

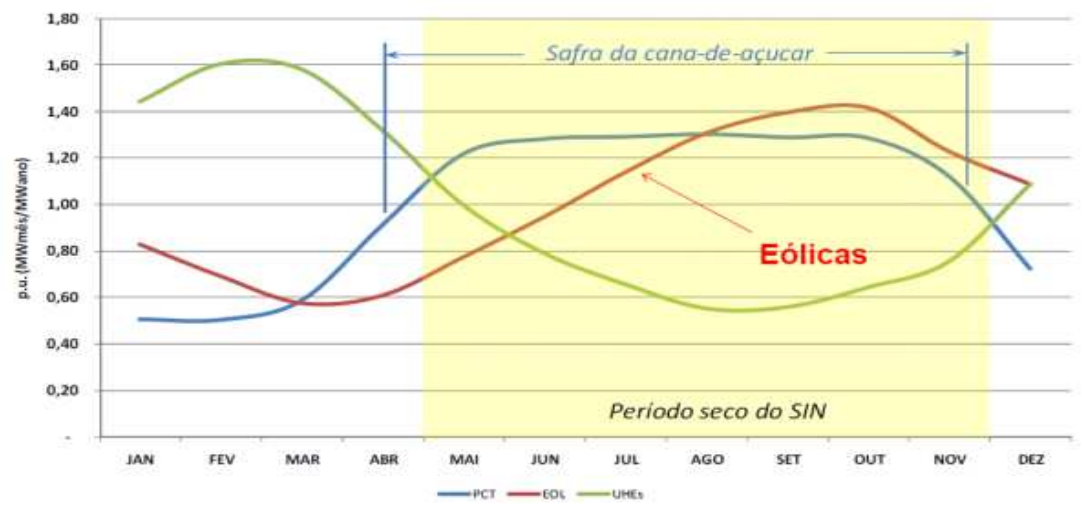

Figura 14 - Perfil de produção de energia (Biomassa vs. Geração de pequenas hidrelétricas vs. Geração eólica) Valores em por unidade do total de Garantia Física de plantas de 30 MW de capacidade instalada Fonte: ONS (2011)

A Figura 14 mostra o perfil de geração para centrais elétricas a biomassa, PCH e eólica em valores por unidade de GF. Nesta figura é possível observar o risco que as plantas estão expostas ao assinar um contrato para fornecer $100 \%$ de sua garantia física ao longo do horizonte de tempo: sempre que a geração está abaixo dos $100 \%$ da GF, a planta é exposta ao mercado de curto prazo. Assim, se por um lado a usina hidrelétrica enfrenta seus períodos de déficit de produção nos meses de maio a novembro, período de seca quando os preços spot são elevados, as plantas a biomassa e eólicas estão lucrando com a venda de seu excedente no mercado spot. 
Por outro lado, durante o período de entressafra (dezembro a abril), a situação reverte para a posição exatamente oposta em que as plantas de biomassa e eólica tornam-se deficitárias e a hidrelétrica apresenta um excedente de produção esperada de energia. Portanto, uma consequência natural é estudar o potencial de cobertura de uma carteira composta por essas fontes, explorando suas possibilidades de sinergia.

A complementaridade das fontes renováveis, dada sua relevância para o SEB, tem sido objeto de estudo e podem ser encontrados artigos de nível internacional que tratam do assunto, bem como algumas teses de Mestrado e Doutorado. Apesar de um tema conhecido, dada sua complexidade, recente abordagem e diferentes perspectivas, ainda há carência de referências bibliográficas. As primeiras abordagens substanciais do assunto foram realizadas em Projetos de Fim de Curso (PFC), orientados pelo Prof. Dr. Dorel S. Ramos, para alunos de engenharia da Escola Politécnica da Universidade de São Paulo (USP).

Um projeto de formatura desenvolvido em 2007, referenciado em (19), apresentou um estudo de complementaridade envolvendo as fontes hidrelétrica, representada por uma $\mathrm{PCH}$, e termelétrica a biomassa de bagaço de cana. A análise, feita do ponto de vista econômico, objetivou mostrar que, por meio da sinergia existente entre os perfis de geração, era possível estabelecer um mecanismo de proteção, ou hedge, às variações de preço de curto prazo e de produção energética, permitindo ganhos em termos de mitigação de risco financeiro.

A simulação foi realizada utilizando-se duas usinas balanceadas em potência; adicionalmente, para o contrato de venda, foram consideradas duas possibilidades, um "flat" e outro sazonal, levando em consideração os períodos úmido e seco do SIN. Os resultados obtidos mostraram que, quando considerado um portfólio com ambas as fontes, há um retorno financeiro maior do que se analisadas separadamente. Além disso, o contrato com perfil sazonal também obteve os melhores resultados, pois explora de forma mais significativa o binômio produção energética e expectativa de preço.

Outro projeto de formatura, referenciado em (20), explorou a complementaridade entre três fontes: PCH, biomassa e eólica. A abordagem avaliou a probabilidade de receita abaixo de um limite mínimo em relação a uma receita livre de risco, representada pela alocação de toda a garantia física disponível em um contrato de longo prazo, sem exposições ao mercado de curto 
prazo. A partir de um nível de aceitação de risco determinado, foram simuladas combinações envolvendo as três fontes, buscando aquela que provê ao investidor a maior receita.

As simulações utilizaram séries históricas de vazão e dados determinísticos de geração eólica e biomassa. Nesse trabalho foi simulada a possibilidade de contrato "gangorra", ou sazonal, que aloca percentuais diferentes ao contrato de longo prazo para as épocas de ano "úmida" e "seca", as quais, notadamente, apresentam tendências de comportamento distintos de preço e disponibilidade hídrica.

Em (21) foi estudada a complementação entre pequenas centrais hidrelétricas e usinas eólicas, considerando incertezas em cenários futuros de geração. Foi feita uma análise das possibilidades de contratação de geradores hidrelétricos e de usinas eólicas, por meio da simulação de diversos cenários de receita e risco de exposição.

Esse estudo apresentou uma ênfase maior na análise da produção eólica, com dados de curva potência para um tipo específico de turbina, e dados de medição diária consolidados de quatro anos. Para ajuste dos dados de medição, consideram-se os dados de rugosidade do terreno na região de coleta dos dados.

As conclusões do trabalho indicam que, para resultados de receita da fonte eólica com grandes desvios em relação à média, o mecanismo se torna muito arriscado do ponto de vista da PCH e muito vantajoso do ponto de vista da eólica, pois as compensações entre as fontes ficam desbalanceadas, uma vez que a PCH fornece uma segurança à geração eólica na maior parte do tempo. Esse resultado é alinhado com aqueles obtidos nessa dissertação para análise de uma eólica cuja garantia física foi dada pelo critério de P50 versus a mesma eólica pelo critério de P90.

Em (22) foi avaliado o risco de receita financeira que incide sobre uma PCH e um Parque Eólico, em função da exposição ao mercado de curto prazo, quando a energia é comercializada no mercado livre. $\mathrm{O}$ artigo considera a complementaridade energética entre fontes e indica diretrizes ao investidor para formação de um portfólio de usinas diversificado, maximizando a receita esperada e minimizando o risco de exposição a receitas reduzidas. Foi desenvolvido um modelo econômico-financeiro para realizar a projeção de preços e de geração e os resultados foram extraídos de três etapas distintas de simulação. 
Primeiramente, avaliou-se o impacto da modelagem dos ventos da usina eólica para (i) fatores de capacidade mensais baseados na média mensal do histórico utilizado no estudo; (ii) dados do histórico e; (iii) fatores de capacidade probabilísticos, baseados em distribuições de probabilidade de fatores de capacidade mensais. Os resultados mostram que a simulação por fatores médios pode mascarar os riscos aos quais o investidor está exposto. Nesse caso, o maior valor de risco associado ao portfólio que utiliza a eólica com dados históricos reconstituídos é um claro sinalizador de que um ponto ótimo de investimentos norteado por dados médios pode não estar aderente à realidade da fonte.

O artigo também apresentou estudos referentes a um mecanismo de mitigação de risco de geração para a fonte eólica, similar ao que hoje existe para as hidrelétricas. Além disso, traz resultados de risco e retorno do portfólio formado pelas fontes eólica e hidráulica, ressaltando o benefício do "hedge" resultante da sinergia que estas fontes têm entre si.

Um recente trabalho de P\&D desenvolvido por RAMOS et al. (2012) (23), em parceria com ANEEL e CESP, explora os aspectos da complementaridade das fontes sazonais exploradas no Brasil, através da estruturação de uma carteira mista com o auxílio de algoritmos genéticos como ferramental de apoio à tomada de decisão. Nesse estudo, são utilizados como dados de entrada, o lastro, fornecido pela Garantia Física sazonalizada das usinas pertencentes ao portfólio, e o montante total alocado em contratos de venda, os quais, ao serem comparados mensalmente, fornecem o montante ao qual o agente estará exposto no MCP. Somando-se à receita advinda do contrato o valor da liquidação no MCP, obtêm-se a receita total, que é o objeto de otimização do estudo, dado um determinado valor de risco limite ao qual o agente está sujeito, medido através do CVaR (Conditional Value at Risk). Adicionalmente, o trabalho propõe uma análise financeira, que verifica a atratividade de investimento, baseada no cálculo do custo unitário das fontes Eólica, Biomassa e PCH, para então maximizar o Valor Líquido Presente (VPL), dada a vida útil dos empreendimentos e uma taxa de desconto pré-determinada. São analisados cenários distintos em termos de custo unitário dos empreendimentos (iguais ou distintos) e do tipo de contrato de venda ("flat" e gangorra), buscando uma maior similaridade e reproduzindo situações enfrentadas pelos agentes de geração na gestão do risco e tomada de decisão (24).

Outro recente trabalho, desenvolvido por (3), apresenta um modelo de negócio para incentivar as empresas que hoje possuem Hidrelétricas em seu portfólio a investirem em usinas a Biomassa e Eólicas, como medida de mitigação de riscos de negociação no mercado de energia brasileiro, 
dado a sinergia que existe entre as fontes. Este trabalho apresenta uma interessante análise financeira, na qual é formada uma Sociedade de Propósito Específica (SPE), destinada exclusivamente à negociação da energia advinda de um portfólio diversificado. Neste caso, a empresa que negocia fontes complementares apresenta um menor fator de risco do que um agente de geração puramente hidrelétrico, o que torna o fluxo de caixa da empresa mais estável e, consequentemente, facilita a obtenção de créditos a menores taxas de juros para investimentos em novas plantas ou aquisição de empreendimentos em construção ou operação.

O trabalho considera o CAPEX (sigla em inglês para Despesas de Capital) do investimento e a vida útil dos projetos para a determinação da Receita Anual Equivalente, a um determinado fator de recuperação de capital. Novamente, os resultados demonstram que o melhor benefício financeiro existe quando as duas fontes, biomassa e eólica, são acrescidas ao portfólio contendo apenas a usina hidrelétrica.

Em (25) é apresentado um estudo analisando a mitigação de riscos em mercados de energia tipicamente hidrotérmicos, como é o caso do SIN. Nesse trabalho foi desenvolvido um modelo de programação linear estocástica de dois estágios para explorar a sinergia entre a sazonalidade da oferta de energia de PCHs e BIOs, de forma a reduzir o risco e maximizar a receita de uma empresa tipicamente comercializadora de energia elétrica. A receita é o resultado do montante advindo do contrato de venda, somada à exposição ao mercado Spot, seja esta positiva, no caso da geração ser maior do que a venda, ou negativa, caso o volume de contrato de venda seja maior do que a geração. O lastro, nesse estudo, é composto pela garantia física das usinas PCH e BIO, cujas parcelas foram determinadas pelo modelo de otimização estocástica. A aversão ao risco é calculada através do CVaR, com um nível de aceitação entre 95\% e 99\%. O estudo compara o lucro líquido de dois casos típicos: um onde apenas é contratada energia de fonte BIO e outro onde é feito um balanço entre $\mathrm{BIO}$ e $\mathrm{PCH}$ para lastrear os contratos de venda. Os resultados apresentaram valores de CVaR muito mais elevados no primeiro caso do que no segundo, onde houve uma combinação das fontes.

Uma evolução em relação ao artigo anterior, disponível em (26), inclui a fonte eólica no estudo, conferindo uma análise de risco através do CVaR para um portfólio combinado dadas as configurações do mercado de energia nacional e a característica de produção de cada fonte. No caso da eólica, a expectativa de geração média foi obtida com base na curva de capacidade de uma planta típica da região Nordeste do país para geração de cenários. 
Um estudo desenvolvido por (27) analisa a mitigação dos riscos de mercado através da contratação de um portfólio diversificado de fontes renováveis. Através de um modelo de programação linear estocástica de dois estágios, buscou-se a solução ideal que maximiza o retorno dado um determinado nível de risco aceitável. As simulações levaram em consideração perfis de geração das fontes BIO, EOL e PCH. Os resultados apresentaram maiores retornos e menores riscos quando duas ou mais fontes foram combinadas em um portfólio, enquanto os maiores riscos estão associados a portfólios contendo apenas uma fonte.

Uma comparação com o artigo apresentado por Street et al. mostra que em ambos os estudos, os maiores retornos estão associados a carteiras contendo apenas a fonte BIO, porém com os maiores riscos associados. Tal fato pode ser explicado pelo perfil de geração típico desse tipo de usina, cujo período de safra e, consequentemente, de geração de energia, coincidem com o período de seca no país, que tende a apresentar preços mais elevados no mercado de energia, seja no curto prazo, de maneira mais expressiva, ou no longo prazo, menos expressiva.

Entretanto, dada a grande volatilidade dos preços, esse cenário de alta nos preços no período de safra pode não se consolidar em alguns períodos, sequenciais ou não, expondo o agente que utiliza como lastro apenas esse tipo de energia a um risco muito elevado, inviabilizando o negócio.

Nesse artigo também foi abordado o tema da diversidade de portfólios utilizando como base a Teoria dos Jogos. É assumido um jogo cooperativo, onde cada jogador representa uma unidade de geração, com uma determinada garantia física, no qual deve-se tomar a melhor decisão entre vender sua energia através de um contrato de médio prazo, com preço fixo, ou deixar uma parcela de sua garantia física descontratada, buscando maiores ganhos com a liquidação no curto prazo ao PLD. Com o objetivo de maximizar a aversão ao risco, assumiu-se que conjuntos de jogadores podem formar alianças, de forma que suas garantias físicas se complementem, gerando produtos cuja negociação trará benefícios para ambos. Tais alianças, quando formadas por jogadores cuja geração tem perfil complementar, possuem um produto mais robusto, podendo oferecer preços mais agressivos no mercado, o que significa uma grande vantagem sobre as alianças com portfólios menos complementares. Isso é evidenciado por combinações EOL e $\mathrm{PCH}$, bastante complementares, versus BIO e EOL, pouco complementares em um determinado período de tempo " $\mathrm{t}$ ", normalmente caracterizado por um ano. 
Dessa forma, para os agentes de geração de fontes alternativas, faz-se necessária uma análise sobre a decisão de se investir em um determinado projeto que vai além de suas características técnicas isoladas, pois a complementaridade com outras usinas já existentes no portfólio podem trazer uma vantagem econômica extra, que precisa ser mensurada antes da tomada de decisão. 


\section{ANÁLISE DE RISCO}

\subsection{Conceitos}

No que se segue, são apresentados os conceitos necessários ao desenvolvimento do instrumental de análise de Risco de Mercado que se impõe considerar na formulação e elaboração da modelagem para avaliação da estratégia de comercialização de fontes de produção intermitentes no mercado livre.

\subsection{Teoria do Portfólio (TP)}

A análise de carteiras de ativos financeiros consolidou-se a partir dos estudos pioneiros de Harry Markowitz, que revolucionou a forma das teorias em finanças encararem o risco com a publicação do "Portfolio Selection" (Markowitz, 1952).

Ao contrário do raciocínio predominante da época, Markowitz (1952) demonstrou matematicamente que numa carteira de ativos (portfólio), a relação entre a taxa do retorno esperado e o risco correspondente a esse retorno depende da correlação existente entre os comportamentos dos ativos da carteira.

A análise de investimento, sob a luz da TP, é realizada tendo como informações de entrada apenas as médias e os desvios padrões dos retornos (históricos ou projetados) dos ativos componentes da carteira em foco e que representam, respectivamente, os seus retornos e riscos.

Em suma, segundo Markowitz, a média de um ativo representa o retorno e o desvio padrão o risco (risco ao se tomar a decisão pela média). Se o desvio padrão for calculado a partir dos logaritmos naturais dos retornos, em vez de os próprios retornos, este desvio padrão será chamado de volatilidade. Alguns financistas optam pela utilização da volatilidade, por esta capturar melhor o efeito dos juros composto no risco.

O Retorno da carteira $R_{c}$ é uma função linear do produto do peso dos ativos na carteira $W_{i}$ pelos seus retornos individuais $R_{i}$. 


$$
R_{c}=\sum_{i=1}^{N} W_{i} R_{i}
$$

Por sua vez, o desvio padrão $\sigma_{c}$ da carteira depende das correlações entre os ativos $\rho_{i j}$ que as integram:

$$
\sigma_{c}=\sqrt{\sum_{i=1}^{N} W_{i}^{2} \sigma_{i}^{2}+\sum_{i=1}^{N} \sum_{j=1}^{N} W_{i} W_{j} \rho_{i j} \sigma_{i} \sigma_{j}}
$$

A situação de menor risco para uma carteira é aquela onde os ativos que a compõem tenham uma correlação perfeitamente negativa $(\varrho=-1)$, pois nessa situação, a parcela da fórmula que contem a correlação atua como um redutor do risco da carteira. Neste caso, tem-se uma estabilidade na receita esperada e com possibilidade limitada de auferir receitas muito elevadas, que implicaria em incorrer níveis de risco maiores.

Seguindo a mesma linha de raciocínio, o pior caso para uma carteira é aquele onde os dois ativos estão totalmente correlacionados $(\varrho=1)$, pois neste caso a parcela da fórmula que contem a correlação majora o risco da carteira.

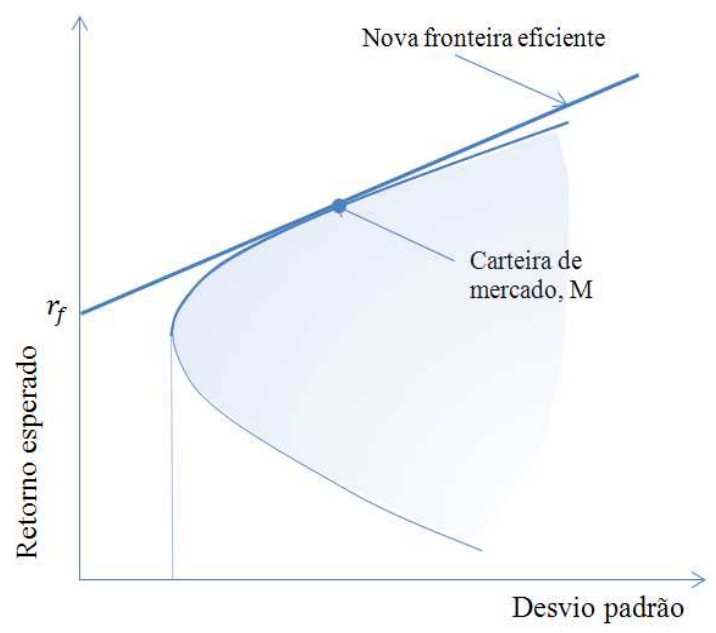

Figura 15 - Fronteira Eficiente de um ativo com risco (Fonte(34))

A representação gráfica do risco e do retorno das inúmeras composições de carteiras, que é possível se formarem com as combinações de composições de " $\mathbf{n}$ ” ativos, resultam em gráficos com áreas formadas por hipérboles e a área formada pelas intersecções das hipérboles, resulta numa envoltória, sendo possível demonstrar matematicamente que a envoltória de uma família de hipérboles é uma hipérbole! A essa envoltória dá-se o nome de fronteira eficiente de portfólios ou fronteira eficiente de ativos com risco. 
Dessa forma, pode-se encontrar a carteira que para a condição de retorno desejada ofereça o menor risco, permitindo o investidor saber a porcentagem de capital a investir em cada ativo que compõe a carteira de risco mínimo.

A carteira ideal deve mesclar convenientemente o máximo retorno com o mínimo risco, aferindo assim, a melhor relação retorno/risco. Para tanto, deve-se resolver um problema de maximização do quociente do retorno pelo risco.

\subsection{Métricas de Risco}

O risco pode ser compreendido como a possibilidade de ocorrência de um evento não desejável ou adverso. As métricas de risco permitem mensurar a possibilidade esperada de ocorrência do evento e quantificar o valor esperado da perda decorrente.

Para o investidor, no que tange à avaliação de projeto, é levada em consideração a sua capacidade de honrar os compromissos de curto-prazo e exigência de liquidez de caixa, o que torna importantíssima a avaliação do risco como variável decisória (Lima, 2002).

Ademais, devido às peculiaridades do modelo de comercialização de energia no Sistema Interligado Nacional (SIN), os agentes privados podem vender a energia gerada no mercado de curto prazo ('spot'), o que exige a adoção de estratégias adequadas de atuação para atingir resultados positivos de comercialização, mitigar os riscos e maximizar os resultados financeiros.

Um dos principais pontos de análise dos agentes do setor de energia elétrica está na gestão dos riscos aos quais estarão expostos, seja através da aplicação de instrumentos financeiros ou na mitigação dos riscos. Neste contexto, o gerenciamento de risco visa tratar dos fatores que podem ser identificados, suas quantificações e a aplicação de instrumentos para a mitigação dos mesmos.

Os riscos que afetam os agentes do setor elétrico podem ser agrupados, segundo Ojanen (2002) (36), Liu (2006) (37), Souza (2008) e Mayo (2009) (38), em cinco grandes grupos de riscos: de Mercado, de Volume (ou de Demanda), de Crédito, Operacionais e de Regulação (Legais e Regulatórios). 
Os Riscos de Mercado possuem origem na volatilidade dos preços de ativos e passivos financeiros e podem ser subdivididos em:

i. Riscos de base: originados da relação imperfeita entre os preços futuros e do preço no mercado spot;

ii. Risco de liquidez: incapacidade da transação (compra/venda) dos ativos e a de honrar obrigações;

iii. Riscos de volatilidade e de correlação: relacionado às volatilidades que afetam a previsão dos valores futuros dos instrumentos financeiros e o fator da perda de correlação entre estes;

iv. Riscos de câmbio: contratos expostos às variações entre a moeda local e a do contrato;

v. Risco nos indexadores de preços: alterações desfavoráveis nos indexadores que definem a correção monetária aplicável aos contratos de financiamentos e empréstimos que foram celebrados;

vi. Riscos de investimento: afetam a rentabilidade prevista para o empreendimento com o término de algumas concessões para exploração dos serviços prestados e a renegociação das mesmas;

vii. Riscos de preços: relacionados com as flutuações de custos de geração de energia elétrica.

viii. Regulatório: relacionado à mudança de legislação (Ex: Registro de energia "exante" - Portaria MME 455/2012; Introdução de Mecanismo de Aversão ao Risco no modelo Newave - Resolução CNPRE 03/2013, etc).

ix. Operação: incertezas na conexão, produção (que podem acarretar na exclusão do MRE para PCHs), disponibilidade.

Os riscos de Volume ou de Demanda estão na incerteza sobre a produção e o consumo de eletricidade. Condições climáticas adversas ou variações no consumo afetam os preços e o montante de volume a ser gerado.

A esse tipo de riscos está associado o risco hidrológico. No caso dos empreendimentos hidrelétricos, as incertezas da estimativa dos fatores hidrológicos podem resultar em variações no volume gerado e na volatilidade dos preços. 
Há também riscos relacionados à insuficiência de lastro de um agente gerador, que corresponde à diferença entre a média da energia assegurada liquida mensal ou geração líquida mensal somados aos contratos de compra e a média dos contatos de vendas mensais. Se o balanço não for mantido, os agentes sofrem severas penalizações (exposição anualizada x máximo $\left(\mathrm{VR}^{20}\right.$ (ano); PLD Médio (mês)/12).

Tem-se ainda riscos relacionados à estratégia de sazonalização adotada, flexibilizações contratuais, exposição à diferença de preços entre submercados, perda do desconto na tarifa de transporte (fontes incentivadas), riscos do "momento" da tomada de decisão, indexação.

Os riscos de exposição à diferença de preço entre submercados são oriundos da subdivisão do mercado de energia em regiões geoelétricas com características distintas de geração, transmissão e carga. Devido a essas diferenças, foi adotado um sistema de liquidação considerando quatro submercados diferentes a fim de se estabelecer o equilíbrio da energia produzida e vendida em cada um destes submercados. Para efeito de liquidação, quando um determinado agente vende energia para uma carga pertencente a um submercado diferente daquele que está localizado, fica com uma posição positiva em seu submercado de localização e com uma posição negativa no submercado da carga, pois a liquidação das exposições se dá pelo PLD do submercado onde está localizado cada um dos agentes. Da mesma forma, posições assumidas em um determinado submercado podem necessitar de fechamento através de contratos bilaterais em um submercado distinto (por alguma condição comercial vantajosa ou por indisponibilidade de energia no submercado da posição aberta). Tal situação apresenta risco (ou oportunidade), pois os preços entre submercados podem apresentar grande descasamento.

No caso de risco de perda de desconto na tarifa de transporte de energia, podem ocorrer dois tipos de perdas de desconto da TUSD, a parcial ou a total, no caso de fontes incentivadas, quando:

- O agente comprar energia em contratos de energia convencional em montante superior a 49\% de sua Garantia Física. Neste caso a usina, junto à Distribuidora, não perde o seu desconto original, mas, para fins de repasse ao comprador, a usina perde desconto original.

\footnotetext{
${ }^{20}$ Valor de Referência - valor médio ponderado de aquisição de energia proveniente de novos empreendimentos de geração, nos leilões realizados nos anos A-5 e A-3, para início de entrega no ano em questão.
} 
A usina perde o desconto caso ultrapasse o limite de potência de 30 MW injetada na rede (quando houver ultrapassagem em pelo menos três períodos dentro do mês e ainda, se reincidir a ultrapassagem dentro de um período de 12 meses, a usina será modelada como convencional especial por 12 meses - se ultrapassar o limite de $50 \mathrm{MW}$, caso haja reincidência, o agente será modelado por 12 meses como convencional).

Para usinas não despachadas centralizadamente, sem o recurso da GF e fora do MRE, pode-se utilizar o recurso da média móvel de desconto, sendo solicitada a CCEE no mês de dezembro de cada ano.

Desconto $(\mathrm{R} \$)=\%$ Desconto CCEE $\times$ Tusd $(\mathrm{R} \$)$

Ressarcimento de perda de desconto concedido pela Geradora $(\mathrm{R} \$)$ = Valor do Ressarcimento da TUSD (R \$MWh) x (\% Desconto Contrato - \% Desconto CCEE )/(\% Desconto Contrato) $\mathrm{x}$ Energia Medida (MWh)

\section{Usina com GF:}

Desconto $=\frac{\text { GF da usina } \times \text { Desconto da Usina }+ \text { Contratos de Compra } \times \text { Desconto do Vendedor }}{\text { Máx (Total de Vendas } ; \text { Lastro Desconto })}$

Garantia Fisica + Contratos de Compra*

\section{Usina sem GF:}
Desconto $=$ Geração da usina $\times$ Desconto da Usina + Contratos de Compra $\times$ Desconto do Vendedor
Máx ( Total de Vendas; Lastro Desconto)

Geraçāo + Contratos de Compra*

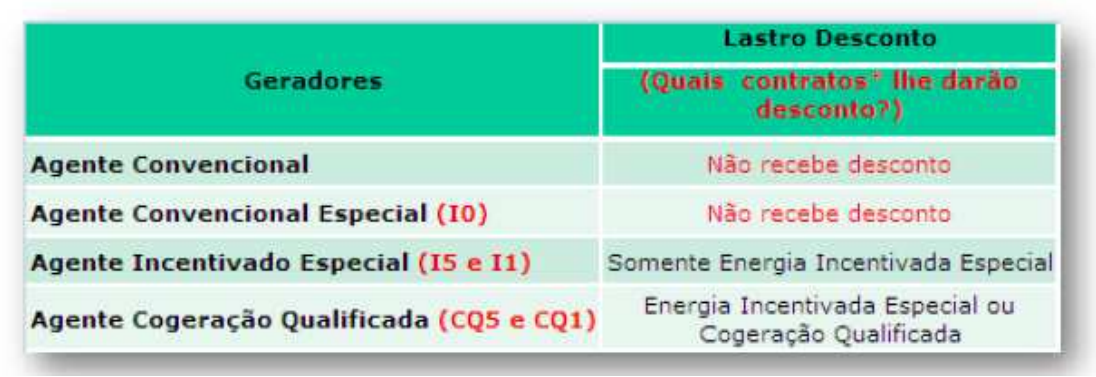

Figura 16 - Desconto na Tarifa de Transporte (Fonte: (5)) 
Os riscos de Crédito (Contraparte) são provenientes da probabilidade do não recebimento de obrigações das contrapartes contratuais. A pulverização de contratos nos leilões entre as geradoras e distribuidoras ajudam na minimização desses riscos, já que são celebrados vários contratos entre os agentes e a probabilidade de inadimplência diminui.

Os riscos Operacionais referem-se ao comprometimento da operação do sistema que podem impactar negativamente no suprimento de energia elétrica e por consequência, na remuneração do agente. Podem ser gerados por falhas nos equipamentos ou humana, incidentes e acidentes em geral.

Por fim, têm-se os riscos Legais e Regulatórios, que são associados às brechas nas leis ou mudanças nos regulamentos que podem impactar os atores de forma negativa, como a criação de encargos não previstos ou brechas para quebra de contratos. As questões ambientais de licenciamento ou a demora na concessão podem ser classificadas dentro da área de riscos legais.

Nos investimentos em empreendimentos de geração de energia, o risco do negócio está associado às variações da rentabilidade do projeto, aos lucros provenientes da produção de eletricidade e a comercialização da energia.

A gestão comercial do projeto, onde se estabelece o nível de exposição ao mercado de curto prazo (mercado "spot") e se define os parâmetros dos contratos (prazo e preço) de venda de energia elétrica (que são essencialmente, as garantias do financiamento), é uma das decisões mais importantes a ser tomada pelo investidor, representando uma variável estratégica para o analista financeiro considerar na avaliação de projetos de geração (Lima, 2002).

Os agentes do setor frente à vasta gama de riscos aos quais estão expostos, de diferentes origens e impactos, procuram aplicar instrumentos de mensuração em cada situação de exposição e buscam no mundo das finanças as principais metodologias de avaliação dos riscos. As metodologias de mensuração de riscos mais comuns no mercado são: Value-at-Risk (VaR), Conditional VaR (CVaR) e o Cash Flow-at-Risk (CFaR).

\section{Value-at-Risk (VaR)}

Com ampla aplicação na indústria de finanças, a metodologia Value-at-Risk ( $V a R$ ) é uma medida estatística que permite medir o risco inerente a cada carteira de investimento e pode ser definida 
como uma métrica capaz de medir a mínima perda de uma posição (ou uma carteira), ativa ou passiva (comprada/vendida), num determinado horizonte de tempo e com uma certa probabilidade de ocorrência (intervalo de confiança).

Escolhe-se, portanto, um quantil da distribuição de resultados da carteira como medida de risco. Este quantil, conhecido como Value at Risk de $\alpha \%\left(\mathrm{VaR}_{\alpha \%}\right)$ é um valor de resultado pessimista, que garante que somente em apenas $(1-\alpha) \%$ dos cenários obteremos resultados inferiores ao valor fixado.

As principais limitações à aplicação do VaR consistem no fato de que:

(i) o indicador em questão não fornece a medida das perdas potenciais que excedem o valor do próprio VaR;

(ii) quando empregada para otimização de carteiras pode causar um alongamento na cauda da curva de distribuição de perdas, criando um potencial de perdas mais elevadas quando estas ultrapassam os próprios valores do VaR; e

(iii) a sua aplicação é de difícil otimização, exceto quando assume uma distribuição normal para as variáveis de mercado na qual está sustentado.

(iv) não pode ser somado.

\section{Conditional Value-at-Risk (CVaR)}

O Conditional Value-at-Risk foi desenvolvido para contornar as limitações do VaR, indicando de forma mais adequada o potencial de perdas que ultrapassam o intervalo de confiança ao calcular a média das perdas que excedem o valor do VaR.

Dessa forma, o CVaR pode ser definido como o valor médio esperado do excedente das perdas que ultrapassam o valor do VaR. Com efeito, a sua aplicação permite que se obtenha uma carteira menos exposta a valores extremos, do que a otimizada pelo VaR.

O gráfico da Figura 17 a seguir ilustra bem a diferença entre VaR e CVaR. As duas distribuições distintas apresentam um mesmo valor de $\mathrm{VaR}$, porém os valores de $\mathrm{CVaR}_{1}$ e $\mathrm{CVaR}$ são distintos, devido o efeito do alongamento da cauda das distribuições. 
Sendo assim, o CVaR representa uma restrição condicional, onde a sua limitação superior é dada pelo VaR: $C V a R \leq V a R$. Observa-se também que ao aplicar o CVaR, é possível capturar melhor a exposição a valores extremos de uma carteira.

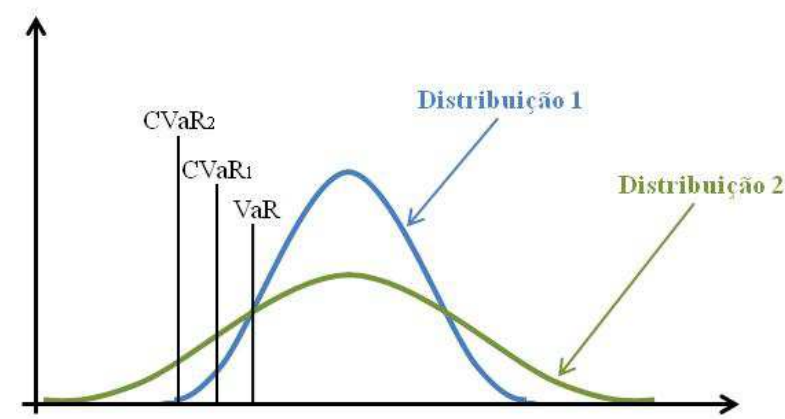

Figura 17: Gráfico de distribuição e indicação de $V a \mathrm{R}$ e CVaR.(Fonte: (35))

\section{Cash Flow-at-risk (CFaR)}

Outra variação do $V a R$ para aplicação em instituições não financeiras é o Cash Flow-at-Risk $(\mathrm{CF} a \mathrm{R})$, que mede o máximo déficit esperado de um fluxo de caixa projetado para um determinado período, dentro de um determinado intervalo de confiança, podendo envolver a simulação de incertezas de médio prazo, riscos de volume e mesmo restrições do sistema (Denton, 2003).

O CFaR representa o valor do montante em risco, dada uma distribuição de probabilidade do fluxo de caixa operacional da empresa, sobre um horizonte futuro de fluxos de caixa, dentro de um determinado intervalo de confiança (Stein, 2001).

Ambos, VaR e CFaR, podem ser estimados por Monte Carlo; o primeiro por covariância e o segundo por Balanço de Cenários. A metodologia CFaR, por definição, tem grande aplicabilidade nos projetos de geração de energia devido a sazonalidades de geração de energia e a necessidade de mitigação dos riscos para controle de fluxo de caixa. Como essa metodologia está associada ao controle de risco em fluxo de caixa (FC), o horizonte de tempo utilizado normalmente são meses ou anos, onde se modela uma estimativa de possíveis cenários para o FC dessas companhias, permitindo assim, medir a máxima perda esperada a partir da expectativa do valor futuro (Souza, 2008). 


\section{Função Utilidade}

A função utilidade traduz em unidades do perfil de risco do agente o valor que este atribui às receitas. Descreve a atitude do agente frente ao risco: aversão, neutralidade ou atração.
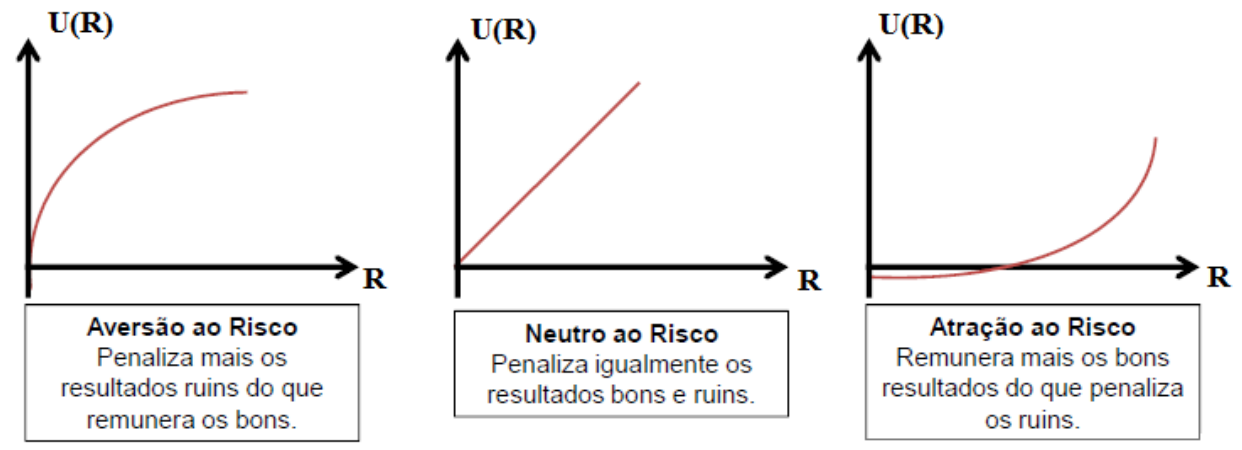

Figura 18: Gráfico da Função Utilidade (Fonte: (39))

O perfil de aversão ao risco é caracterizado pelo coeficiente de aversão ao risco, em que o ganho de utilidade por uma variação positiva não é igual (em valores absolutos) à perda devido a uma variação negativa de mesma intensidade.

\section{MaxMin}

Consiste em restringir a receita a um valor maior que uma receita mínima. Outra opção seria maximizar o pior cenário dos resultados.

\subsection{Precificação de ativos e negócios em energia}

Precificar um projeto ou uma oportunidade de negócio significa atribuir um valor monetário pelo qual estaríamos indiferentes entre este montante e tal oportunidade. Para isso, pode-se utilizar medidas de risco ou utilidades para encontrar o valor, ou equivalente certo, de um determinado projeto (39).

O preço do risco pode corresponder a:

$$
\operatorname{Risco}=\Delta=E(R)-E C(R)
$$


No caso de um agente que valora pelo $\mathrm{CVaR}_{\alpha}$ :

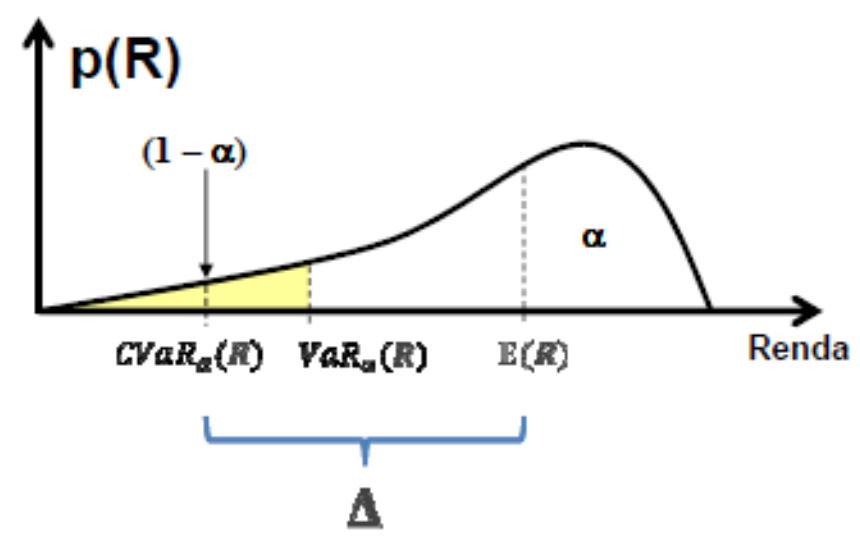

Sendo:

Figura 19: Medidas de Risco (Fonte: (39))

- Receita Líquida (R): Soma das receitas e despesas do portfólio;

- Distribuição da Receita: Distribuição de probabilidade da receita líquida para um dado intervalo de tempo.

- Valor Esperado (E(R)): Valor esperado da receita líquida, dada sua distribuição de probabilidade.

- Nível de Confiança $(\alpha)$ : Percentil $(1-\alpha) \%$ da distribuição da receita líquida;

- Valor-em-Risco (VaR $\alpha)$ : Valor que corresponde ao percentil $(1-\alpha) \%$ da distribuição da receita líquida. Para um dado valor $\mathrm{VaR} \alpha$, a probabilidade de se obter um valor de $\mathrm{R}>$ VaR $\alpha$ é $\alpha \%$;

- Valor-em-Risco Condicionado $(\mathrm{CVaR} \alpha)$ : Valor esperado da receita líquida nos cenários para os quais ela é menor ou igual ao $\mathrm{VaR} \alpha$.

Em um contexto de comercialização de contratos, pode-se pensar no sobrepreço necessário para igualar o valor, com e sem este fator de risco.

O equivalente certo pode ser uma medida de valor mista entre a média dos piores cenários e a média geral da distribuição: $V(R)=\lambda \operatorname{CVaR}_{\alpha}(R)+(1-\lambda) E(R)$

(combinação linear convexa entre Receita e CVaR.). E a solução ótima seria a maximização desta função.

Pode-se ainda maximizar o valor esperado e limitar o risco máximo permitido $\left(\operatorname{CVaR}_{\alpha}(R)\right)$. Com isto, otimiza-se para diversos perfis de risco o portfólio renovável e a contratação de um gerador. O perfil de risco é definido pelo $\lambda$ ou pelo risco máximo aceitável. 


\section{Desafios}

O que é preciso para valorar ou precificar um contrato de uma fonte eólica?

No ACR:

- Contratos do LER: um modelo de simulação de ventos

- Contratos A-3 e A-5 (apuração da entrega é mais flexível, mas ainda dependente do PLD): um modelo de simulação de ventos consistentes com os cenários de PLD.

No ACL são negociados contratos com mais fatores de risco

- Risco de preço e quantidade: um modelo de simulação de ventos consistentes com os cenários de PLD, tal modelo deve capturar a dependência entre vento, vazão e PLD, gerando séries sintéticas estatisticamente dependentes. 


\section{METODOLOGIA}

Para conduzir a formulação/execução e análise de estudos de caso, será montado um portfólio de plantas geradoras que possam exibir sinergia energética entre si e que permitam estabelecer um mecanismo de "hedge" (proteção) financeiro robusto. Serão realizadas diversas combinações entre estas, de forma a buscar melhores arranjos, em relação à receita esperada e ao risco associado.

O portfólio aqui abordado será formado inicialmente por:

(i) central hidrelétrica, termoelétrica de cogeração movida a bagaço de cana e central eólica representadas individualmente;

(ii) combinação duas a duas das fontes acima citadas;

(iii) combinação de todas as fontes acima citadas.

À parte da análise de complementaridade energética e dos ganhos operacionais decorrentes, o foco principal estará voltado para a análise sob o ponto de vista econômico e financeiro, buscando estabelecer um nível ótimo de contrato de compra e venda de energia onde as usinas envolvidas corram o menor risco financeiro possível, proporcionando uma espécie de "hedge" entre si.

Para tanto, será necessário consolidar o entendimento claro e atualizado das particularidades da comercialização de energia por plantas hidrelétricas, de centrais eólicas e de plantas de cogeração sazonais movidas a bagaço de cana. Além da sistemática da operação do sistema elétrico brasileiro na atualidade e sua influência no despacho das usinas do sistema.

A formulação dos problemas matemáticos consiste na determinação da função objetivo, a qual normalmente baseia-se na maximização ou minimização de um resultado, na identificação das variáveis de decisão e, finalmente, na inserção de todas as restrições às quais as variáveis estão sujeitas (17). As restrições são utilizadas para delimitar a área dentro da qual todas as soluções são possíveis. O método utilizado para solução de problemas do tipo linear é denominado Programação Linear. A solução geralmente restringe-se à maximização de um dado parâmetro em virtude da variação de outro parâmetro, com algumas restrições específicas para cada caso. Esse tipo de problema, se bem equacionado, pode ser resolvido por uma ferramenta simples de otimização. 
As restrições impostas aos problemas em estudo são de origens diversas, tais como regras de mercado para comercialização da energia, limites físicos das usinas, premissas de despacho, máximo risco ao qual o gerador pode se expor, entre outras que serão equacionadas a seguir.

Considerando um "mix" de usinas será preciso analisar em detalhe a complementação energética entre as fontes citadas, ponderando a geração alocada das usinas hidroelétricas com o despacho efetivo das centrais eólicas e plantas termoelétricas, a fim de definir o atendimento a um determinado nível de contrato de venda dessa energia, na premissa de que o conjunto de usinas em estudo faça parte de uma única empresa ou a empresa compre a curva de geração de outro empreendedor e a incorpore em seu portfólio (hipóteses necessárias para dar sentido prático à análise de "hedge" físico, econômico e financeiro).

Para aferir os resultados de balanço energético de cada usina e do conjunto, quando for o caso, será utilizado uma ferramenta para tratar as séries de geração e preços "spot", obtidas a partir da simulação das séries hidrológicas do histórico registrado de vazões, com o suporte do modelo NEWAVE, que permite a geração dos preços de curto prazo correspondentes a cada série hidrológica e marco temporal (ano e mês do horizonte de simulação). Avaliando-se os resultados econômicos e financeiros decorrentes das opções de venda de energia disponíveis, permitindo determinar o nível ótimo de contratação, de forma a maximizar a receita obtida no longo prazo, respeitando restrições de natureza financeira.

A otimização do problema, que visa à maximização da Receita Total através da variação do parâmetro de alocação da garantia física disponível ao contrato, pode retornar um valor que, na média, pode ser o de maior retorno, mas que pode submeter o agente a valores de exposições negativas extremamente prejudiciais em alguns cenários, o que pode comprometer não apenas o caixa da empresa, mas também toda a estratégia.

Inicialmente serão considerados como restrição:

i. receita mínima para qualquer situação plausível para o sistema (por exemplo, as séries de PLD obtidas para simulação do sistema com o histórico de vazões e cenário de configuração do parque gerador e mercado atendido), e

ii. valor limite para a probabilidade de que as receitas se encontrem em determinada faixa, entre o mínimo aceitável e um segundo valor a ser definido. 
O risco é medido através de probabilidade de Receita Líquida anual abaixo de um valor de receita de referência. Essa probabilidade é realizada com dois limites distintos, um superior e um inferior, os quais podem ser calibrados para melhor atender às condições da simulação em questão. A receita de referência representa a receita total esperada para um caso em que a totalidade da garantia física disponível é alocada ao contrato, sem exposição ao MCP, ou seja, sem custo ou receita adicional advindos do Spot.

O modelo de otimização deve ser capaz de representar a sinergia existente entre as fontes estudadas, com foco na maximização da receita no horizonte de estudo, para um determinado portfólio, dado um nível de aceitação de risco pré-definido, o qual é traduzido na perda de receita em relação a uma receita de referência.

Para cada cenário, o modelo fará uma varredura por todas as possibilidades de alocação de garantia física ao contrato, variando de zero a 100\% do portfólio e, para cada percentual, existirão valores distintos de Receita Líquida Anual, Custo Spot e risco de perda de receita. A convergência ocorre para o nível de contratação com maior Receita Total esperada, cuja probabilidade de cenários de Receita Total líquida abaixo do valor de referência atenda aos critérios de limite inferior e superior de risco. Para cada mês do horizonte de estudo, o modelo irá contar o número de ocorrências de Receita Líquida Mensal abaixo do parâmetro Limite Inferior e dividir esse número pelo total de séries históricas da simulação.

De forma semelhante, para cada mês do horizonte de estudo, o modelo irá contar o número de ocorrências de Receita Líquida Anual abaixo do parâmetro Limite Superior e dividir esse número pelo total de séries históricas da simulação. Finalmente, o modelo irá calcular a média anual de $\mathrm{p}^{\text {Inf }} \mathrm{e}^{\text {Sup }}$ resultantes da análise de todo o horizonte. Esses valores devem respeitar os parâmetros de referência indicados na calibração do problema. Caso estejam fora dos limites, o percentual de alocação $\mathrm{X}_{\mathrm{V}}$ não atende às restrições do problema. Portanto, o modelo deverá varrer todas as possibilidades de $X_{V}$ que satisfaçam às restrições e, dentro dessa área de respostas possíveis, encontrar o ponto que maximize a Receita Total.

A ocorrência de hedge pode ser comprovada nos casos em que a receita total de um portfólio combinado (duas ou mais fontes) é maior do que a soma das receitas totais das usinas analisadas individualmente, para o mesmo nível de risco. 
No Modelo de Negócio, proposto e analisado mais adiante neste trabalho, o cálculo de risco ao qual o agente está sujeito será medido por meio do VaR (perda máxima provável de uma carteira para um nível de confiança $\alpha=95 \%$ ) e CVaR (valor esperado dos $(1-\alpha)$ piores cenários de receita), calculados com base na amostra de séries de receitas anuais esperadas compatíveis com as séries históricas de afluência para cinco anos de horizonte de estudo. A determinação do valor em risco baseia-se no desvio entre a receita esperada e a receita localizada no percentil $5 \%(1-\alpha)$ da distribuição de resultados, já a determinação do valor em risco condicional foi feita para média dos $5 \%$ piores cenários possíveis no horizonte de análise.

Ao maximizar o $\mathrm{CVaR}$ (5\%), o agente busca minimizar o risco do portfólio, reduzindo a probabilidade de perda de receita. Neste caso, os cenários de receitas anuais se concentram mais próximos da média, o que também pode ser traduzido como diminuição do desvio padrão.

Foi estabelecido, então, o valor de Receita de Referência para o portfólio, a partir do qual foi calculado um valor de $\mathrm{VaR}$ limite $\left(\mathrm{VaR}_{\mathrm{Limit}}\right)$, por exemplo $85 \%$ do valor de Receita de Referência, e de CVaR limite ( $\mathrm{CVaR}_{\text {Limite }}$ ), por exemplo 80\% do valor de Receita de Referência. Logo, os resultados do $\mathrm{VaR}$ e do $\mathrm{CVaR}(5 \%)$ da distribuição de receitas do portfólio otimizado devem ser maiores ou iguais aos valores limites estabelecidos, caso contrário, o problema não irá convergir. A tomada de decisão também pode ser feita maximizando o CVaR, o que significa minimizar o risco de receitas abaixo da receita de referência.

O modelo irá retornar então, para cada percentual de garantia física alocada ao contrato de longo prazo, valores distintos de Receita Líquida Anual, Custo Spot e VaR e CVaR. Dentre todas as hipóteses de alocação, aquela que atingir a maior Receita Total e que atenda aos critérios de limite de VaR e CVaR é a resposta otimizada ao problema. Uma segunda análise pode buscar otimizar o critério de CVaR. Nesse caso, o hedge resultante da combinação de fontes estará evidente na proteção à perda de receita, através de um $\mathrm{CVaR}$ maximizado, e não necessariamente no ganho receita.

Será feita também uma análise de sensibilidade ao risco para a combinação de portfólio que apresentou a maior sinergia. A análise consiste em variar o CVaR limite de forma a identificar o comportamento da receita e do ótimo contratado. O objetivo dessa análise é identificar se pequenas variações sobre o risco ao qual se está exposto podem representar ganhos em termo de receita que se justifiquem uma decisão mais ou menos conservadora. 
A seguir descreve-se a modelagem física e comercial de cada fonte de geração considerada neste trabalho.

\subsection{Pequenas Centrais Hidrelétricas (PCHs)}

Geralmente uma PCH opera a fio d'água (sem reservatório) aproveitando os desníveis naturais do rio, o que reduz seu impacto ambiental; por outro lado, a falta de um reservatório não permite a regularização do fluxo de água, podendo causar ociosidade das turbinas em períodos de estiagem ou vertimento em períodos hidrologicamente favoráveis.

A simulação do programa NEWAVE origina os dados de geração mensal do parque nacional (em MWmédios) e os respectivos custos marginais de operação, para os anos de análise e para os cenários hidrológicos. Esta simulação pode ser realizada de duas formas, na primeira são utilizados os dados de energia natural afluente (ENA) históricos, iniciados em 1931 e na segunda são utilizados os dados de séries sintéticas de ENAs, calculadas por auto-regressão com base no histórico de afluências, mas que geram 2000 cenários de vazões e que por isso são mais utilizadas em análises estatísticas.

A modelagem das PCHs pode ser feita de duas formas distintas, dependendo da situação da mesma no sistema:

口 Não pertencente ao MRE: A PCH não é participante do Mecanismo de Realocação de Energia e fica exposta ao risco das vazões para cumprir com os seus contratos. A energia disponível mensal para alocação em contratos é a própria geração da usina.

口 Pertencente ao MRE: A PCH participa do Mecanismo de Realocação de Energia e divide com todos os seus participantes a geração total do sistema, que mitiga o risco de exposição individual dos geradores. A energia atribuída à usina possui uma característica menos variável, porém ainda sazonal, com forte correlação com os preços do mercado de curto prazo. Como raramente as PCHs não participam do MRE e por esta decisão não ser a mais adequada para um investidor que preza pela estabilidade da receita, consideraremos de agora em diante que as $\mathrm{PCH}$ participam do MRE. 
A usina receberá a sua garantia física multiplicada pelo fator_MRE, que é a razão entre expectativa de geração hidrelétrica (resultante de simulações com o modelo de previsão de despacho para cada mês do horizonte de estudo e cenário de afluência), e o somatório da garantia física das usinas participantes do MRE (obtido com base na configuração atual e consideração das expansões por meio de análise do balanço estático do SIN).

$$
\operatorname{Geração~}_{P C H-s, m}=G F_{P C H} * \text { FatorMRE } E_{s, m}
$$

Onde:

Geração $_{\mathrm{PCH}}$ - Energia Alocada da PCH em MWm na série hidrológica s e no mês m

$\mathrm{GF}_{\mathrm{PCH}}-$ Garantia Física da PCH em MWm

FatorMRE - Fator que considera a divisão da energia total gerada pelo MRE entre seus participantes, calculada segundo a fórmula abaixo:

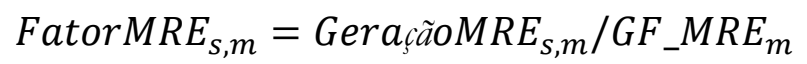

Onde:

GeraçãoMRE - Soma da geração das usinas participantes do MRE

GF_MRE - Soma da Garantia Física das usinas do MRE

O modelo de previsão de despacho leva em conta: a energia armazenada (energia que pode ser gerada por meio de deplecionamento dos reservatórios), a vazão que chega aos reservatórios e pode ser controlada pelo operador - Energia Afluente Controlável e, a vazão que chega aos reservatórios e não pode ser controlada - Energia a Fio d’Água Bruta. A soma de ambas as vazões é a Energia Natural Afluente (ENA) de uma determinada região. Além da ENA, também são transformadas em energia a Vazão Mínima (ou restrição hidráulica), o Desvio de Água (irrigação, abastecimento de residências, consumo industrial) e a Evaporação.

Toda energia potencial disponível (altura - H[m]) para conversão em energia cinética (vazão $\left.\mathrm{Q}\left[\mathrm{m}^{3} / \mathrm{s}\right]\right)$ e então geração de energia elétrica (Potência $[\mathrm{W}]=\varrho($ densidade específica da água $\left.\left[\mathrm{kg} / \mathrm{m}^{3}\right]\right) \cdot \mathrm{g}\left(\right.$ aceleração da gravidade $\left[\mathrm{m}^{3} / \mathrm{s}\right]$. Q . H) é baseada em uma altura de referência correspondente a $65 \%$ do volume útil do reservatório.

Com base na configuração atual e incremento da garantia física proveniente da expansão das usinas hidrelétricas do SIN, conforme previsto no PDE - PMO, obtém-se o balanço estático do sistema para cada mês do horizonte de estudo. 
A expectativa de geração futura, obtida através dos dados de afluência, é então dividida pela garantia física disponível em cada período do horizonte de estudo, obtendo-se, assim, o fator MRE. Quando este fator apresentar valores menores que 1, isso significa que a geração foi inferior à garantia física total das usinas hidrelétricas consideradas no mecanismo, e que haverá um rateio do déficit entre essas usinas, proporcional a um fator denominado "GSF" (Generating Scaling Factor). Quando o fator apresentar valores superiores a 1, isso significa que a geração total do sistema foi superior à garantia física, havendo, portanto, a distribuição da sobra ou "Energia Secundária" às usinas pertencentes ao MRE.

A figura a seguir apresenta os percentis dos fatores de MRE para o PMO de dezembro de 2013, sendo a energia alocada à usina calculada pela multiplicação destes fatores pela sua garantia física. É possível observar o padrão dos períodos úmido e seco.

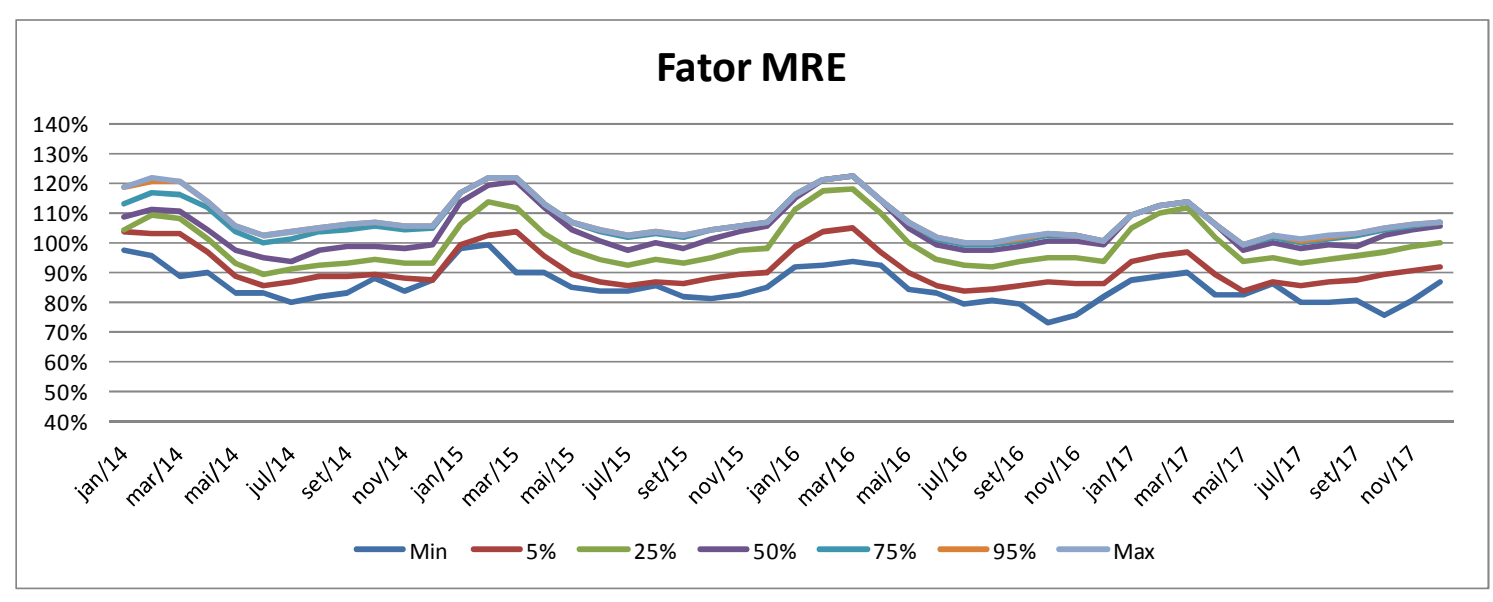

Figura 20 - Fatores MRE (Fonte: Confecção própria)

Os geradores com usinas hidrelétricas em seu portfólio devem ficar atentos, pois nos casos em que a alocação de energia for inferior à sua garantia física o PLD tende a estar muito alto, devido à alta correlação negativa com a geração hidráulica, o que torna arriscado vender um contrato anual de energia firme equivalente a $100 \%$ de sua placa.

A alocação de energia mensal está sujeita também à forma com que os geradores do mecanismo sazonalizam a sua garantia física. Tal impacto não foi considerado neste trabalho dada a imprevisibilidade da estratégia individual dos agentes em função, principalmente, da percepção da evolução da condição de suprimento do sistema. A sazonalização foi considerada constante ("flat") para todo período, o que tem o mesmo efeito da sazonalização da GF da usina para fins de energia alocada seguir a média da sazonalização do MRE. 
Após determinar a geração da usina ou a energia alocada em cada série e em cada mês do horizonte de estudo, a próxima etapa será a de simular a participação comercial desta usina no sistema brasileiro. A figura a seguir apresenta um resumo do modelo de simulação econômicofinanceiro da usina. Para a simulação econômico-financeira da usina são necessários alguns dados de entrada, principalmente em relação ao contrato de longo prazo, conforme abaixo:

- Percentual da Garantia Física comprometida em contratos.

- Sazonalização do contratos, aqui entendido como período úmido e período seco.

- Preço do contrato em cada um dos períodos.

- Cenários de PLD para o horizonte de estudo (no caso utilizamos os cenários do PMO de dezembro de 2013)

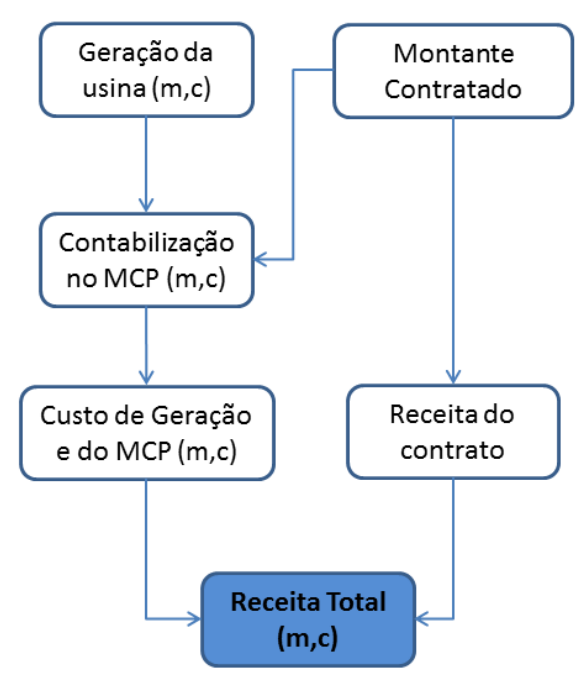

Figura 21 - Modelo de Simulação Econômico-Financeiro (Fonte: Confecção própria)

A tabela a seguir apresenta os dados cadastrais do contrato na planilha de simulação.

Tabela 3 - Dados do contrato

\begin{tabular}{|l|r|}
\hline \multicolumn{2}{|c|}{ Dados do contrato } \\
Preço Úmido & 140,00 \\
Preço Seco (R\$/MWh) & 140,00 \\
Percentual contratado & $100 \%$ \\
Percentual no período úmido & $42 \%$ \\
Percentual no período seco & $58 \%$ \\
Montante contratado (MWh/Ano) & $\mathrm{GF}$ \\
\hline
\end{tabular}

A receita da usina estará então vinculada a duas parcelas, a primeira referente à receita do contrato e a segunda referente à comercialização de energia no mercado de curto prazo, nos 
momentos de sobra ou déficit de energia. As equações apresentadas a seguir demonstram os cálculos realizados para as receitas do contrato, para os montantes e custos de energia comercializada no curto prazo e para a receita total da usina.

$$
\begin{gathered}
\text { Receita_Contrato }_{m}=\text { Mont_Contr }_{m} * \text { Preşo_Contr }_{m} \\
\text { Mont_SPOT }_{m, s}=\text { Mont_Contr }_{m}-\text { Geração }_{m, s} \\
\text { Custo_MCP } P_{m, s}=\text { Mont_SPOT }_{m, s} * P L D_{m, s} \\
\text { Receita_Total }_{m, s}=\text { Receita_Contrato } \\
\end{gathered}
$$

O custo de energia comercializada no curto prazo, por convenção, é positivo quando a usina compra energia no curto prazo e negativo quando esta vende suas sobras no MCP. O resultado da simulação econômico financeira da usina é uma distribuição de receitas anuais, referente aos cenários utilizados, que no caso são as 2000 séries sintéticas do NEWAVE, e para os 4 anos de estudo.

A figura a seguir apresenta a simulação de uma PCH de 19,5 MWm de garantia física com todas as condições sistêmicas e de contratos apresentadas até então. Na média a usina estará vendendo suas sobras no MCP durante o ano todo. Esta sobra é contabilizada através da diferença entre sua energia alocada e sua garantia física comprometida em contrato.

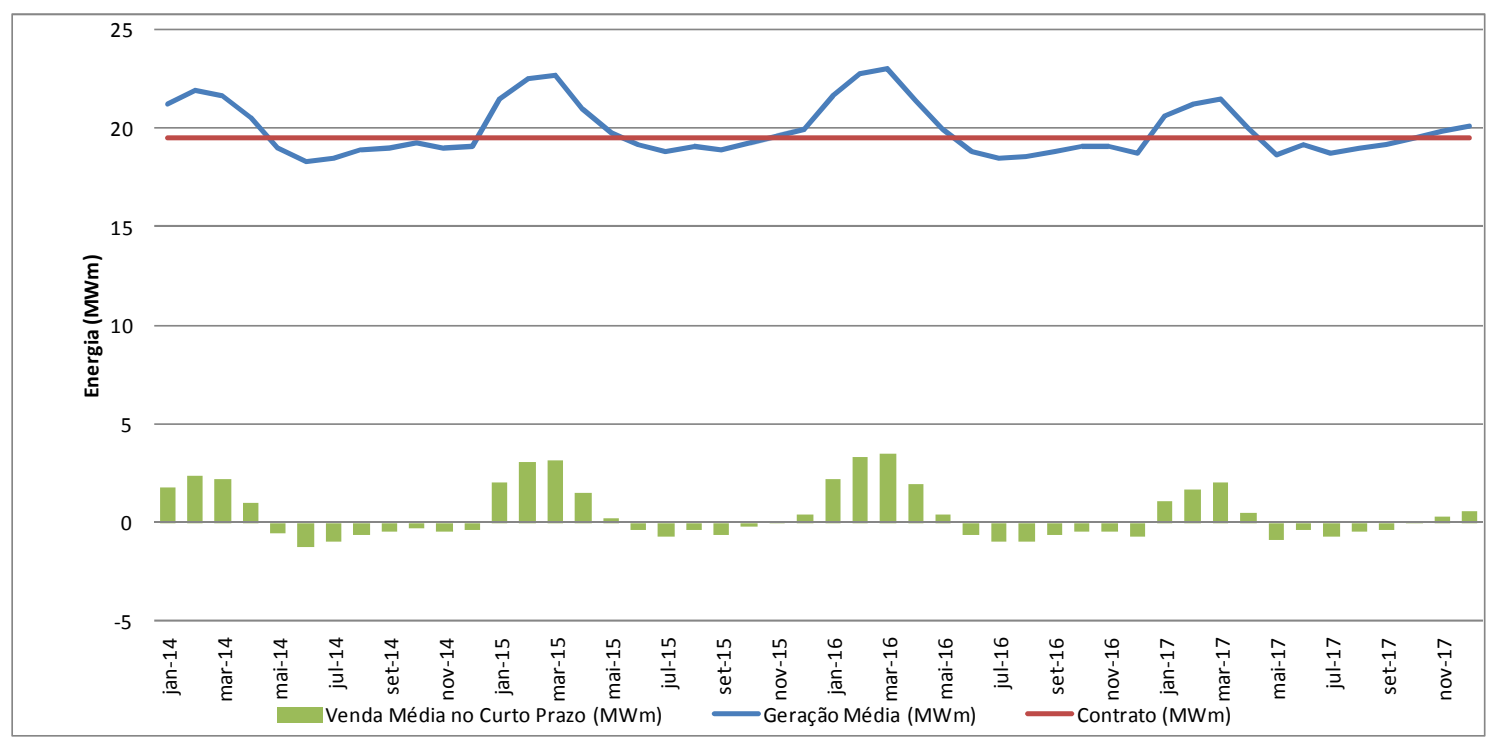

Figura 22 - Montante comercializado no MCP (Fonte: Confecção própria)

As barras da Figura que se segue apresentam a venda média de energia no MCP e as linhas representam os percentis do custo de comercialização de energia no MCP. As condições 
sistêmicas do PMO utilizado na simulação eram de stress o que levou a $\mathrm{PCH}$ a ter número significativo de cenários com escassez de energia, representados pelos valores positivos de CEC, nos quais a PCH terá que comprar energia no MCP para honrar seus contratos por ter energia alocada abaixo de sua GF.

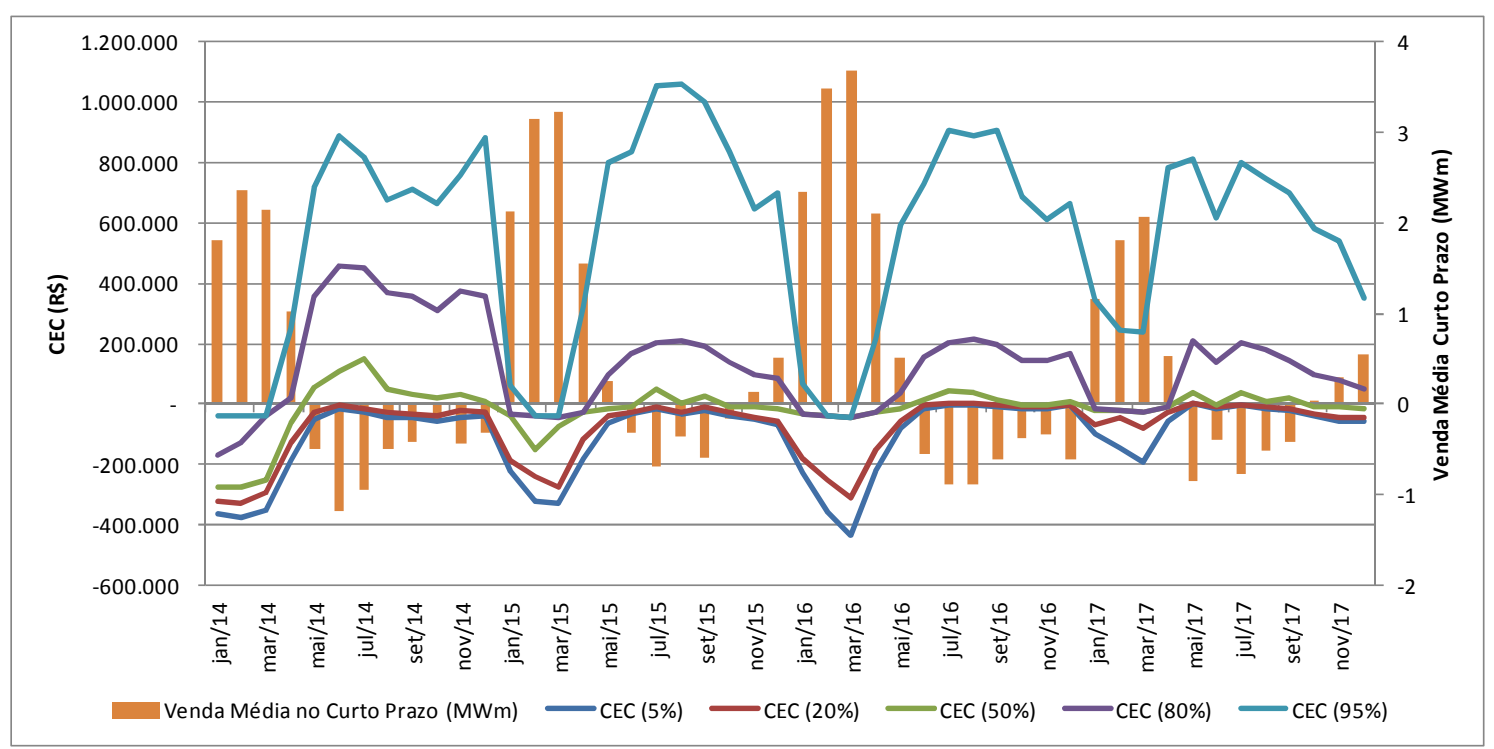

Figura 23 - Custo de Comercialização no MCP para a PCH (Fonte: Confecção própria)

A avaliação do desempenho da usina é então realizada pela expectativa de receita no horizonte e pelos critérios de risco, descritos a seguir:

Receita Anual Média: Representa a expectativa da receita para a empresa na configuração estudada. Este parâmetro, isoladamente, não reflete adequadamente os cenários negativos a que a empresa está exposta.

Desvio Padrão: É a definição de risco para Markowitz. Representa o quanto que a empresa erra ao tomar a decisão pela média. Não é adequada para o caso do setor elétrico devido a assimetria das distribuições de receitas.

- VaR (Valor em Risco): Representa a maior perda que a empresa terá considerando uma determinada probabilidade de exceder este valor, ou seja, uma empresa que tem um $\operatorname{VaR}(5 \%)=1.000,00$ tem 5\% de probabilidade de ter valores abaixo de 1.000,00.

- $\mathrm{CVaR}$ (Valor em Risco Condicional): Representa a média dos cenários abaixo do VaR. Tem se mostrado o melhor parâmetro para a definição de risco no setor. 
A figura a seguir apresenta uma distribuição de receitas anuais e o CVaR (5\%), com a média dos $5 \%$ piores casos analisados.

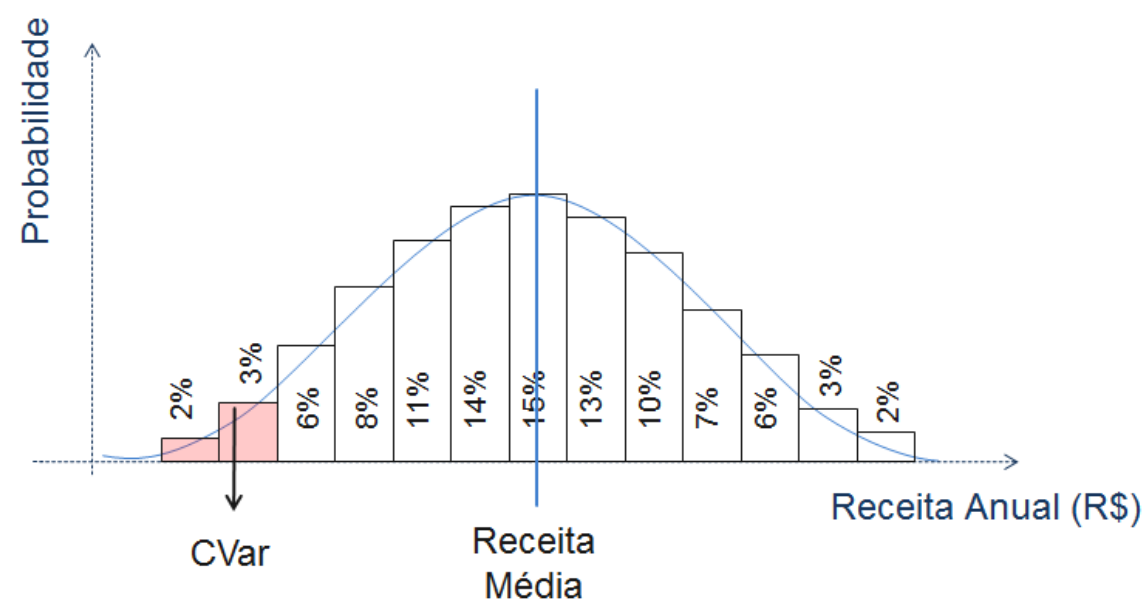

Figura 24 - Distribuição de receitas e CVaR (Fonte: Confecção própria)

A figura que se segue apresenta a distribuição das receitas da $\mathrm{PCH}$, destacando em vermelho o VaR (5\%). Para esta simulação o valor de CVaR (5\%) calculado através da média das receitas 5\% piores cenários foi de $\mathrm{R} \$ 14.517 .878$.

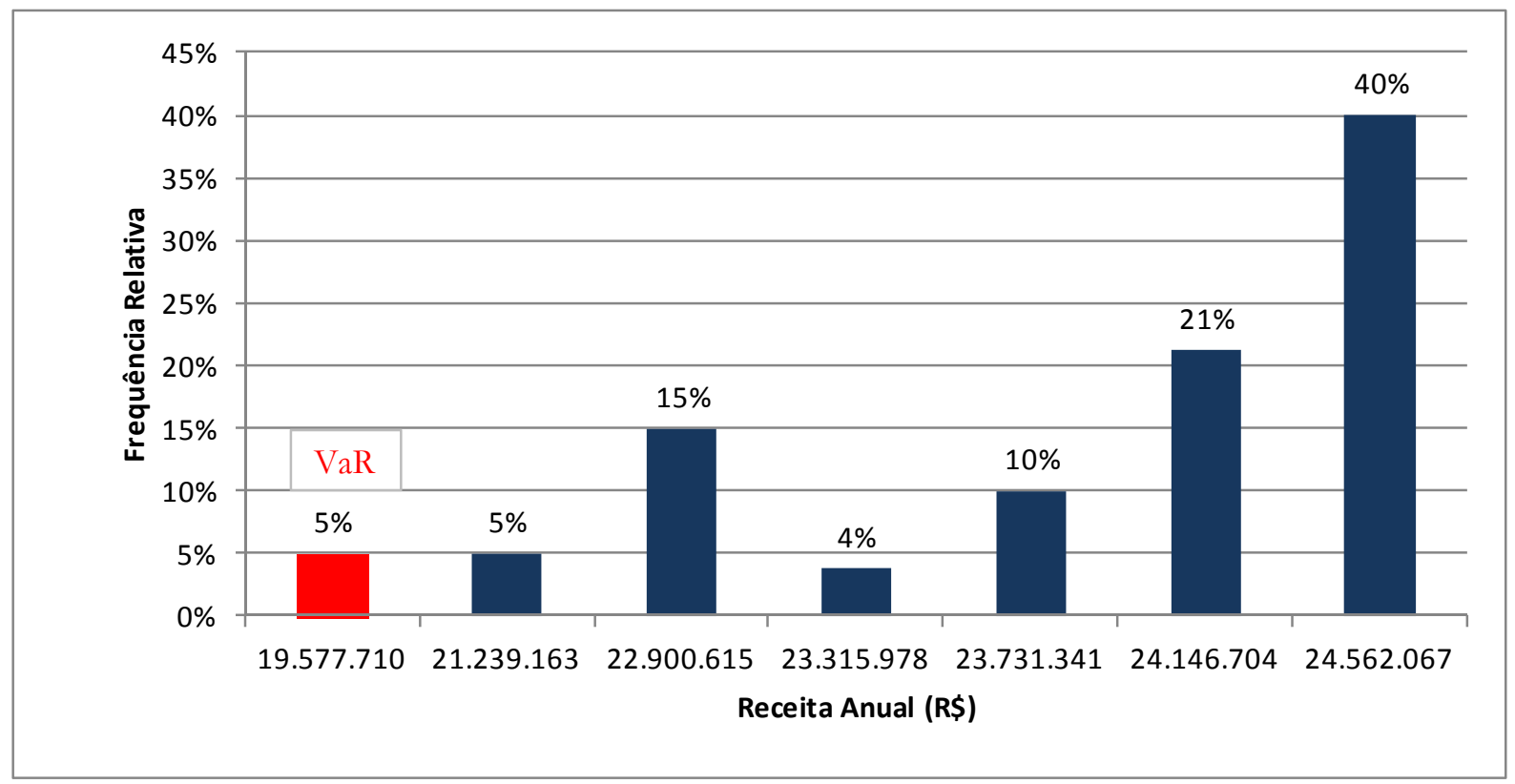

Figura 25 - Distribuição de receitas da PCH (Fonte: Confecção própria) 


\subsection{Biomassa}

A simulação de uma usina movida a biomassa no sistema brasileiro é feita conforme a operação das termelétricas, ou seja, a mesma é despachada em sua disponibilidade máxima mensal quando seu Custo Variável Unitário é menor do que o CMO e despacha a sua inflexibilidade quando em caso contrário.

Neste estudo, simulou-se a biomassa como uma usina termelétrica com CVU nulo e com disponibilidade de geração apenas no período de safra. Como o custo de geração é nulo, a mesma sempre gerará energia quando estiver disponível, independentemente do valor do CMO do sistema. A figura que se segue apresenta os fatores de capacidade mensais da biomassa em estudo.

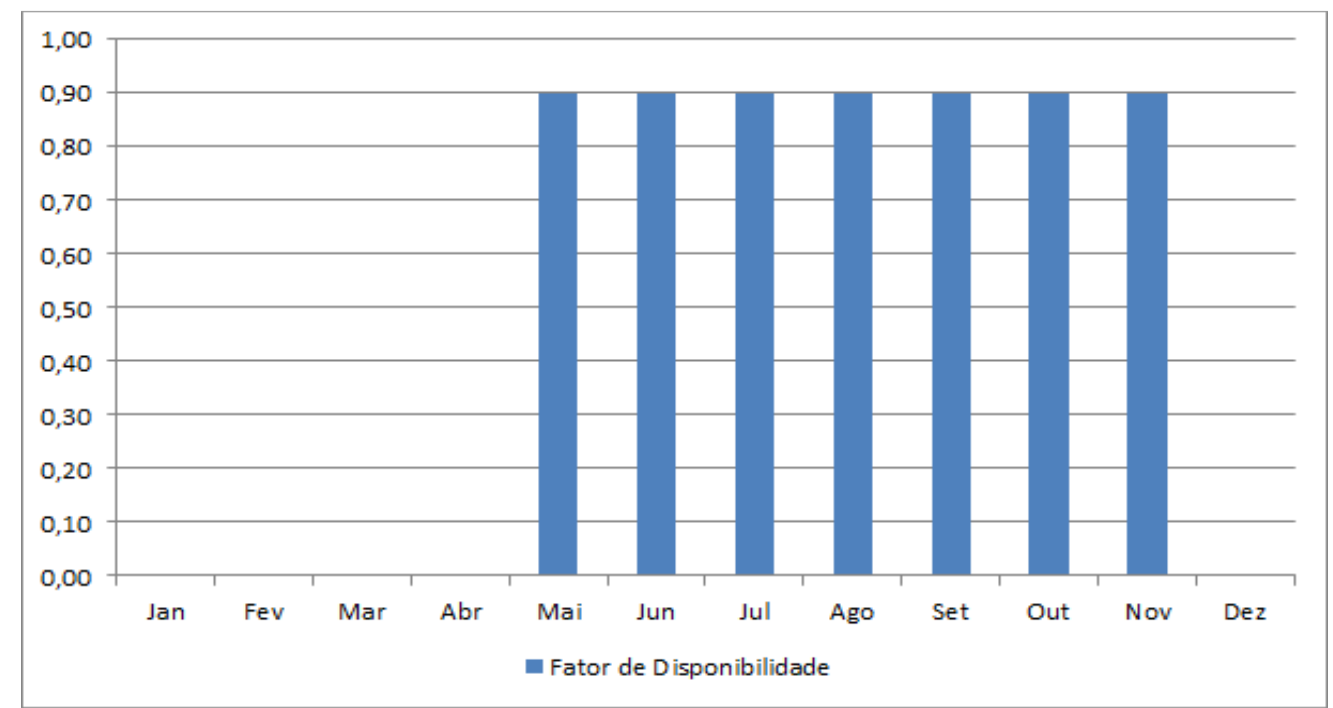

Figura 26 - Fatores de Capacidade Mensais da Biomassa (Fonte: Confecção própria)

A geração da biomassa será então calculada através da seguinte equação:

$$
\text { Geração }_{\text {Bio-m }}=\text { FatorCapacidade }_{m} * \text { PotênciaInstalada }
$$

Como a geração desta biomassa com CVU nulo não é dependente do CMO, a mesma terá a mesma geração para todos os cenários analisados ${ }^{21}$.

21 Por simplificação, não se levou em consideração as típicas paradas não programadas, bem como atrasos e perda na qualidade do bagaço devido a fatores climáticos, em especial chuva (excesso ou falta). 
Para a usina a biomassa, o fator de capacidade mensal assume o valor 0 (zero) fora do período de safra e valor 0,9 no período de safra. Sabe-se que questões intrínsecas à geração a Biomassa, tais como rampa de geração no início da safra, indisponibilidades forçadas e programadas devido a problemas técnicos e atrasos ou quebra de safra são fatores que frequentemente afetam a disponibilidade mensal dessa fonte, porém, tais questões não foram levadas em consideração, dada a característica acadêmica e não econômica do estudo. Após determinar a geração da usina em cada cenário e em cada mês do horizonte de estudo, a próxima etapa será a de simular a participação comercial desta usina no sistema brasileiro. Esta simulação é feita através do mesmo modelo apresentado para a PCH.

A figura a seguir ilustra a comercialização de energia extraída de simulação de uma biomassa de 30 MW de potência instalada e de 14,4 MWm de garantia física com todas as condições sistêmicas e de contratos apresentadas até então. No período úmido em que a biomassa não tem produção de energia, esta estará comprando energia no MCP e no período seco a biomassa vende suas sobras de geração em relação ao montante contratado.

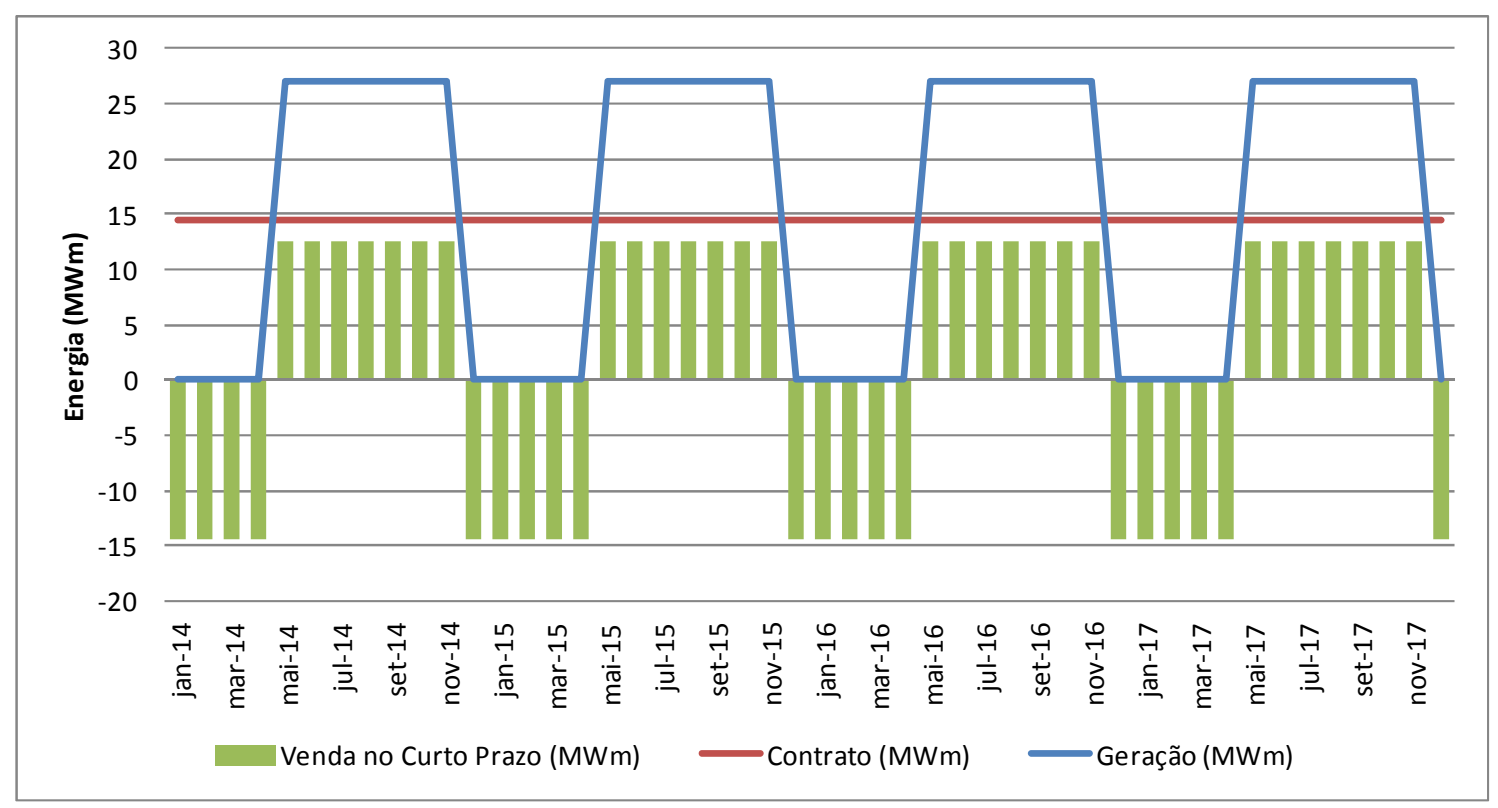

Figura 27 - Montante comercializado no MCP pela Biomassa (Fonte: Confecção própria)

As barras da figura a seguir apresentam a venda de energia no MCP e as linhas representam os percentis do custo de comercialização de energia no MCP. Como a biomassa gera o mesmo montante de energia em todos os cenários, o montante de energia comercializado também será igual em todos os cenários. Neste caso a diferença entre os custos de energia comercializadas no MCP é dada pelos diferentes valores de PLDs em cada série. 


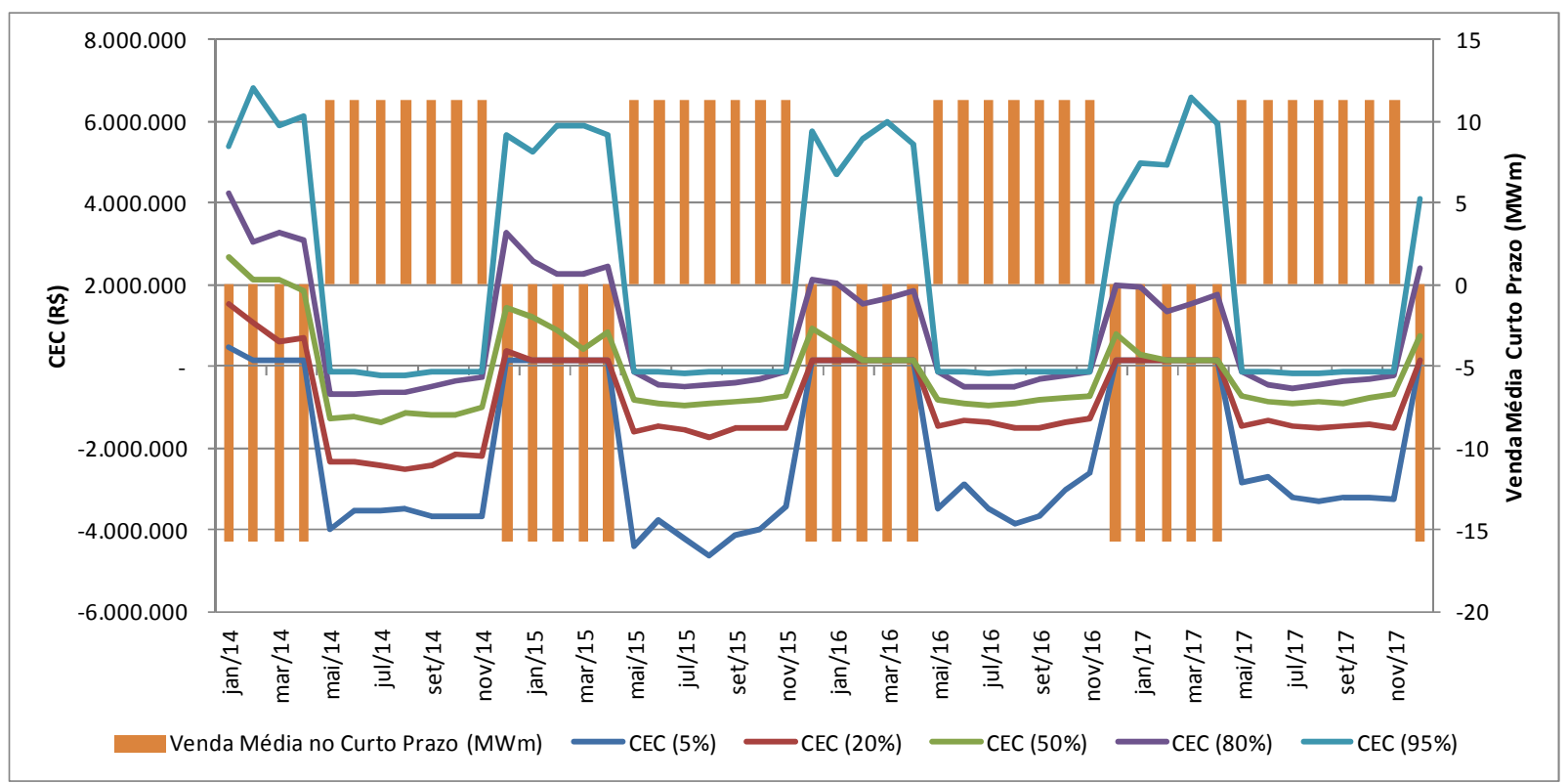

Figura 28 - Custo de Comercialização no MCP para a Biomassa (Fonte: Confecção própria)

A figura a seguir apresenta a distribuição das receitas da biomassa, destacando em vermelho o VaR (5\%). Para esta simulação o valor de CVaR (5\%) calculado através da média das receitas dos $5 \%$ piores cenários foi de $\mathrm{R} \$ 13.136 .721$.

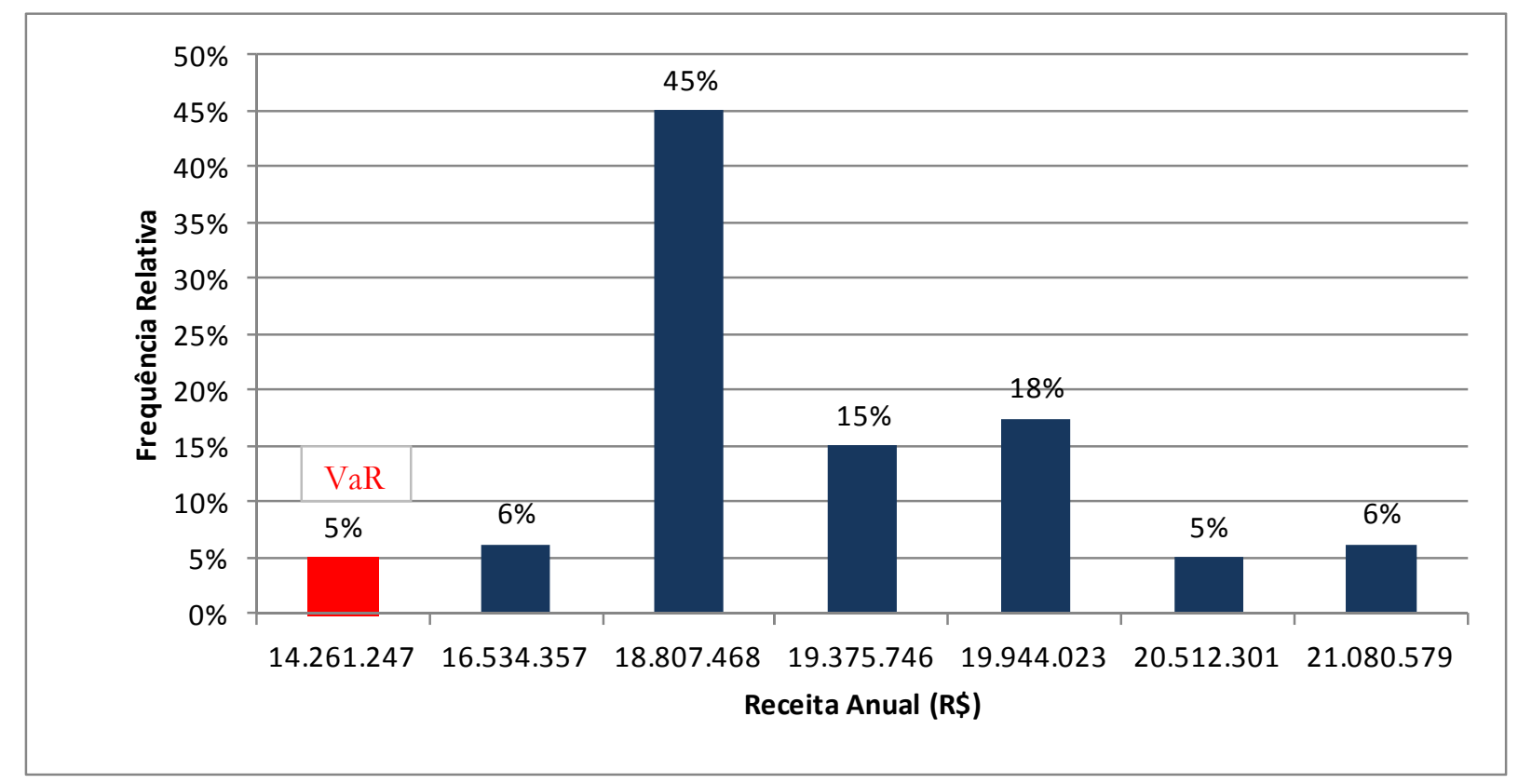

Figura 29 - Distribuição de receitas da Biomassa (Fonte: Confecção própria) 


\subsection{Eólica}

A simulação de uma usina eólica no sistema brasileiro é feita conforme a operação das termelétricas, ou seja, a mesma é despachada em sua disponibilidade máxima sempre que o CMO do sistema é menor que seu CVU. Como as eólicas despacham sempre que existe a disponibilidade de ventos, independentemente do CMO do sistema, esta é considerada como uma térmica com CVU nulo e com fator de capacidade referente à disponibilidade de ventos daquele mês.

A disponibilidade de ventos em um parque eólico é variável durante os anos e os meses. Da mesma forma apresentada para as energias naturais afluentes, os ventos dependem das condições climáticas e apresentam grande variabilidade em torno de sua média de longo termo. O alto risco de contratação no ACL é devido à forte sazonalidade da fonte e a liquidação de diferenças ao PLD.

A figura a seguir apresenta os fatores de sazonalidade médios mensais da eólica em estudo, que inicialmente foi simulada como uma eólica "determinística" apresentando o mesmo fator de sazonalidade mensal para todos os anos de estudo e para todos os cenários analisados.

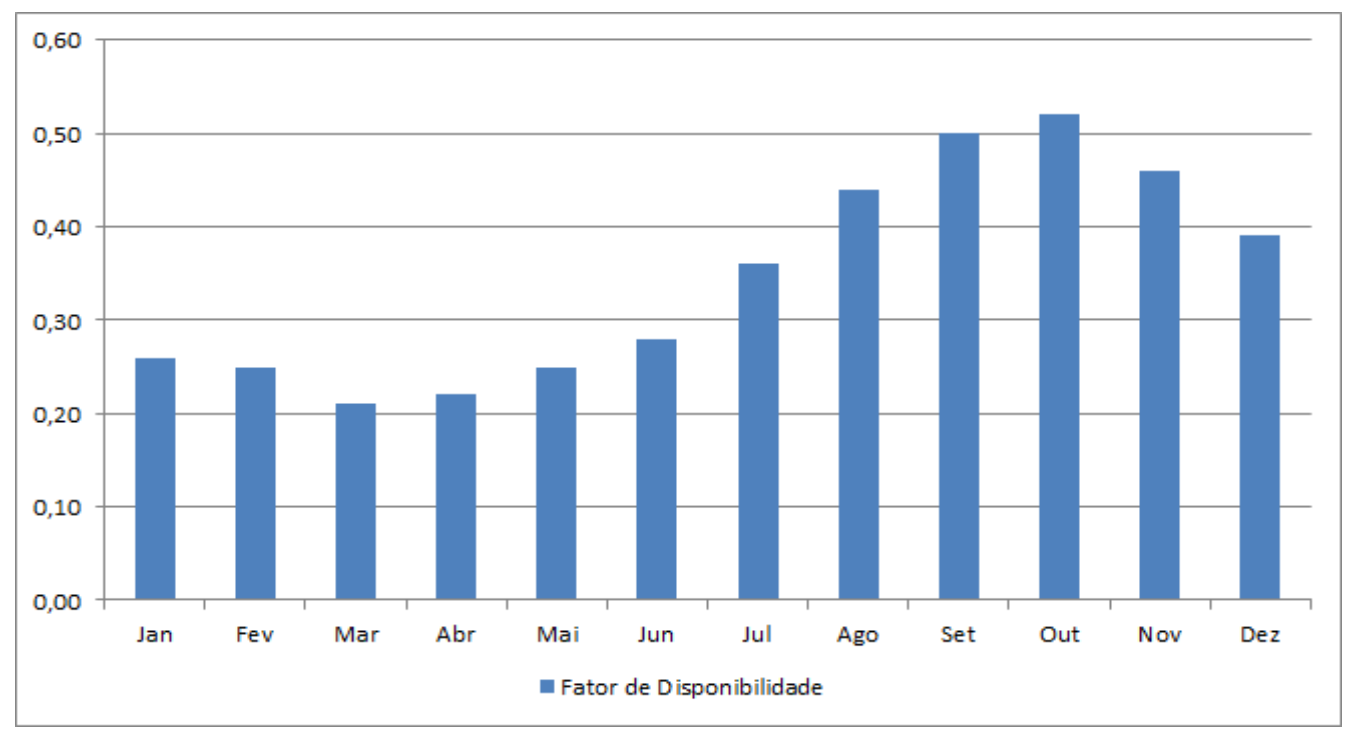

Figura 30 - Fatores de Saz̧onalidade Mensais "Deterministicos" da Eólica (Fonte: Confecção própria)

A geração da eólica será então calculada através da seguinte equação:

$$
\text { Geração }_{\text {Eol-m }}=\text { Fator Sazonalidade }{ }_{m} * \text { Garantia Física }
$$


No cálculo da energia mensal disponível da fonte eólica, na simulação que considera o caso determinístico, considerou-se a garantia física da usina, ponderada por um fator de sazonalidade mensal, que aloca percentuais da garantia física em cada mês, de acordo com o perfil extraído da medição de três anos de um sítio eólico no Estado do Ceará. Nesse caso, o perfil de sazonalização anual é repetido para todo o horizonte de estudo e para cada série histórica.

Para determinação do fator de sazonalização mensal utilizado na eólica determinística, considerou-se a média mensal da geração real medida no medidor de fronteira com a Rede Básica, durante os três anos de histórico, dividida pela garantia física disponível do sítio utilizado como base de dados. As perdas internas já foram descontadas, pois os dados de geração são da fronteira.

Posteriormente, a geração eólica considerada será o histórico reconstituído de 63 anos (19482010) de um macro-sítio do Estado do Ceará e, neste caso, a energia mensal disponível será o resultado da multiplicação da Garantia Física pelo fator eólico, em cada mês e cenário do histórico. O fator eólico foi calculado dividindo-se a geração mensal para cada mês de cada série histórica, para todo o horizonte de estudo, pela garantia física da usina modelo utilizada na reconstituição dos dados.

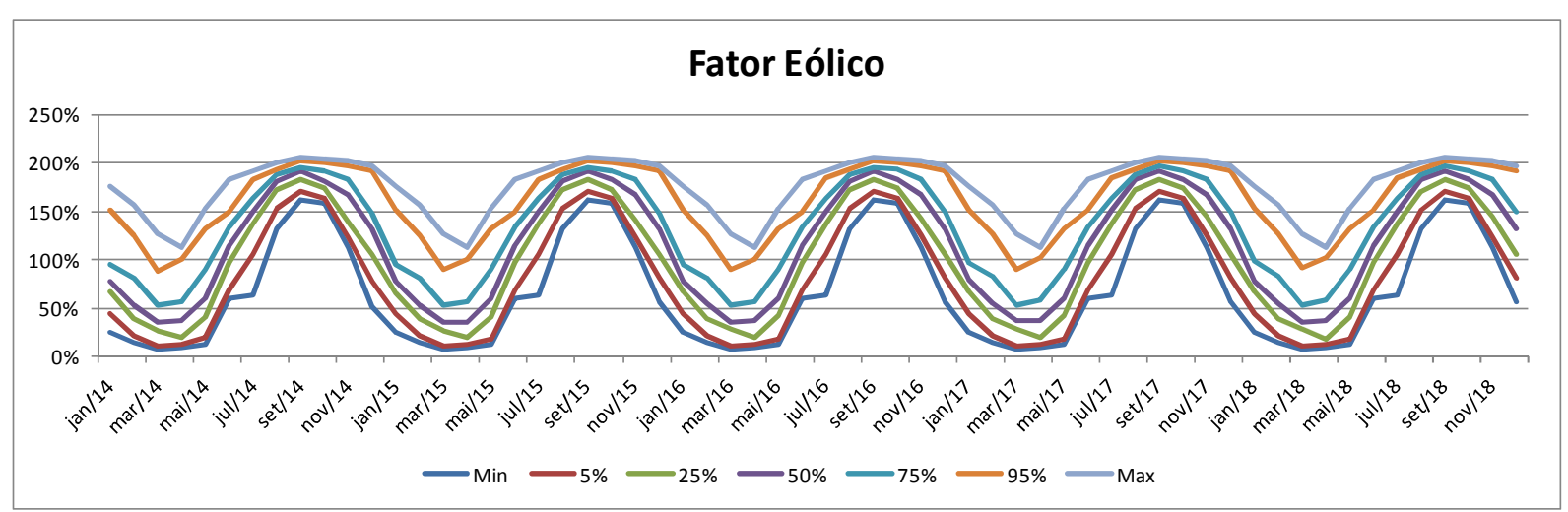

Figura 31 - Perfil de geração eólica no Ceará: histórico reconstituido de 63 anos (Fonte: Confecção própria)

A garantia física da usina eólica utilizada na simulação foi calculada com base nos mesmos dados históricos reconstituídos que deram origem às séries de geração eólica. Uma vez que se utilizou o critério do P90, isso significa que em 90\% das ocorrências, a geração está acima do valor da garantia física. 
O procedimento para obtenção dos dados históricos é descrito em um projeto de $\mathrm{P} \& \mathrm{D}$ desenvolvido para a Duke Energy Brasil, ao qual se obteve acesso.

Em linhas gerais, como parte do estudo compreendido no projeto de P\&D em questão, os dados históricos de vento foram transformados em dados de geração. Isso foi possível através da validação de dados de quatro anos de medição em um modelo de mesoescala Vestas de 10 anos e, em seguida, essa medição de 10 anos foi validada dentro da base NOAA/NCEP, que compreende o período de 1948 a 2010, um total de 63 anos. Então, foi feito o cruzamento das séries reconstituídas de vento com a curva de potência de uma turbina modelo, para a obtenção dos dados de geração eólica em base horária e agregação em dados mensais. Para o presente estudo, foram utilizadas as mesmas séries históricas de CMO e ENA correspondentes ao histórico reconstituído de geração eólica.

Após determinar a geração da usina em cada cenário e em cada mês do horizonte de estudo, a próxima etapa é simular a participação comercial desta usina no sistema brasileiro. Esta simulação é feita através do mesmo modelo apresentado para a PCH.

A Figura 32 que se segue apresenta a simulação de uma eólica de 30 MW de potência instalada e de 14,24 MWm de garantia física com todas as condições sistêmicas e de contratos apresentadas até então, ilustrando a comercialização de energia de uma planta Eólica. Para esta eólica com geração determinística, verifica-se a venda de suas sobras no MCP nos meses em que tiver geração acima da média e compra de energia no MCP nos meses em que gerar menos que a média.

As barras da Figura 33 a seguir apresentam a venda de energia no MCP e as linhas representam os percentis do custo de comercialização de energia no MCP. Como a eólica "determinística" gera o mesmo montante de energia em todos os cenários, o montante de energia comercializado também será igual em todos os cenários, neste caso a diferença entre os custos de energia comercializadas no MCP é dada pelos diferentes valores de PLDs em cada cenário.

A figura 34 a seguir apresenta a distribuição das receitas da eólica, destacando em vermelho o VaR (5\%). Para esta simulação o valor de CVaR (5\%) calculado através da média das receitas 5\% piores cenários foi de $\mathrm{R} \$ 16.234 .227$. 


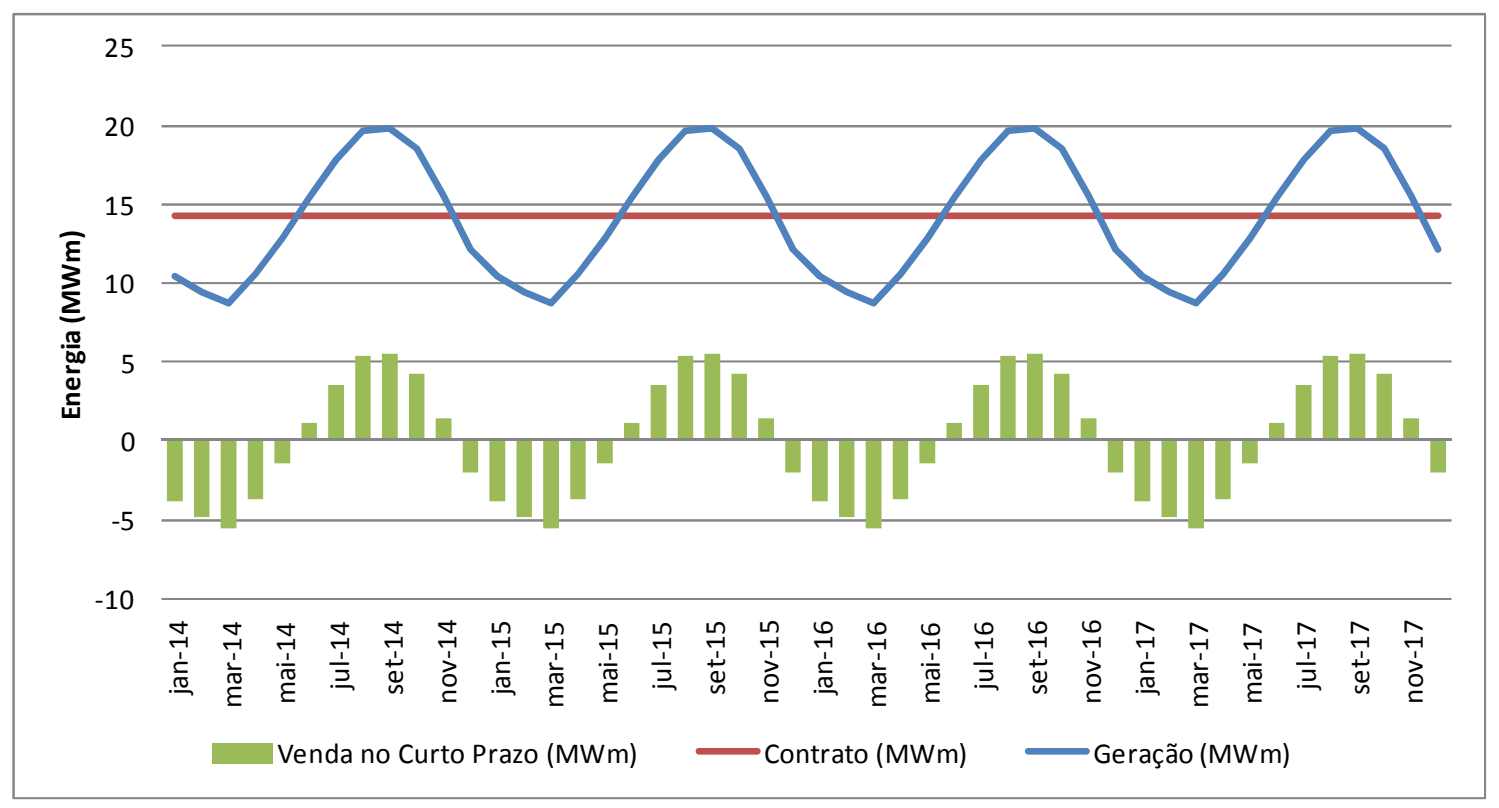

Figura 32 - Montante comercializado no MCP pela Eólica (Fonte: Confecção própria)

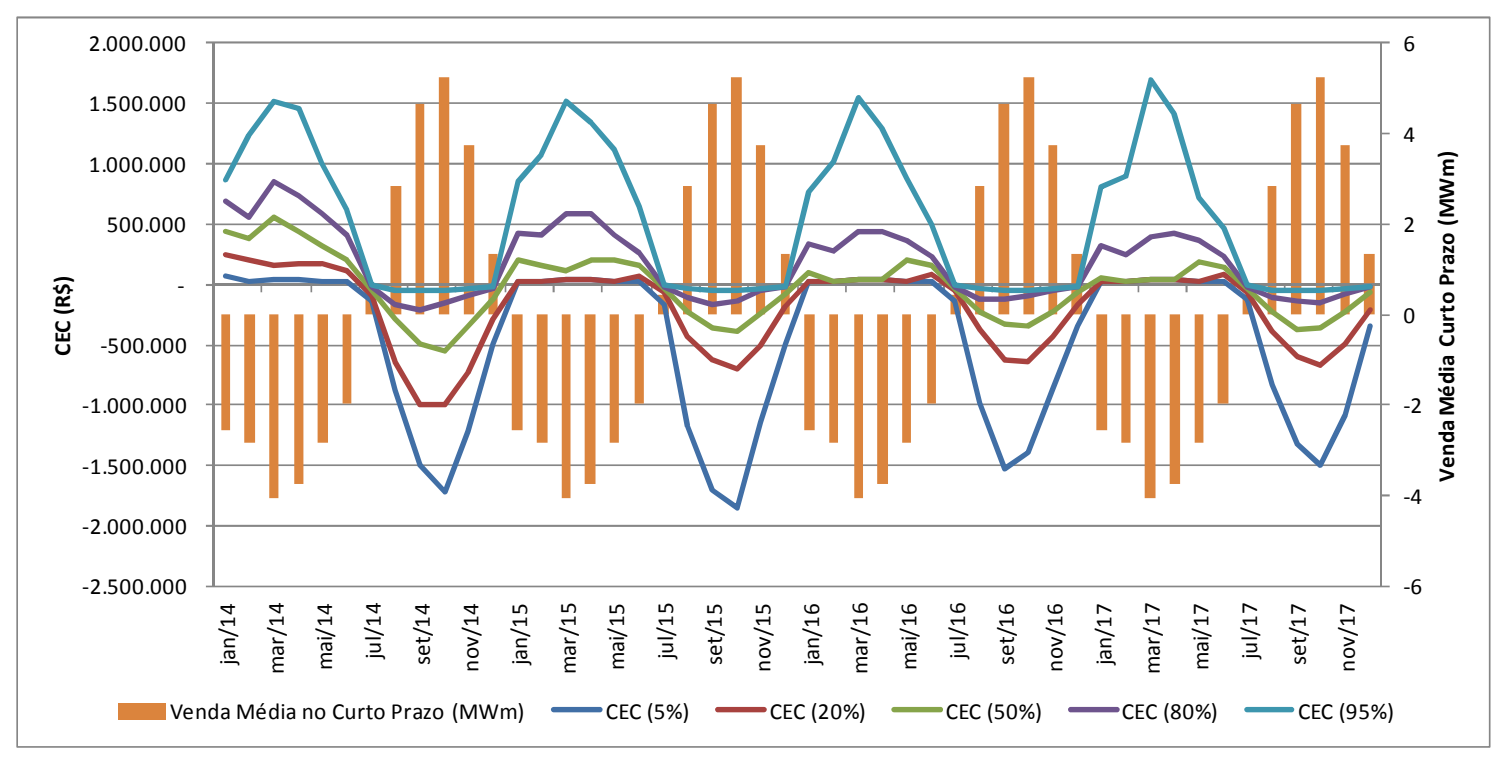

Figura 33 - Custo de Comercialização no MCP para a Eólica (Fonte: Confecção própria) 


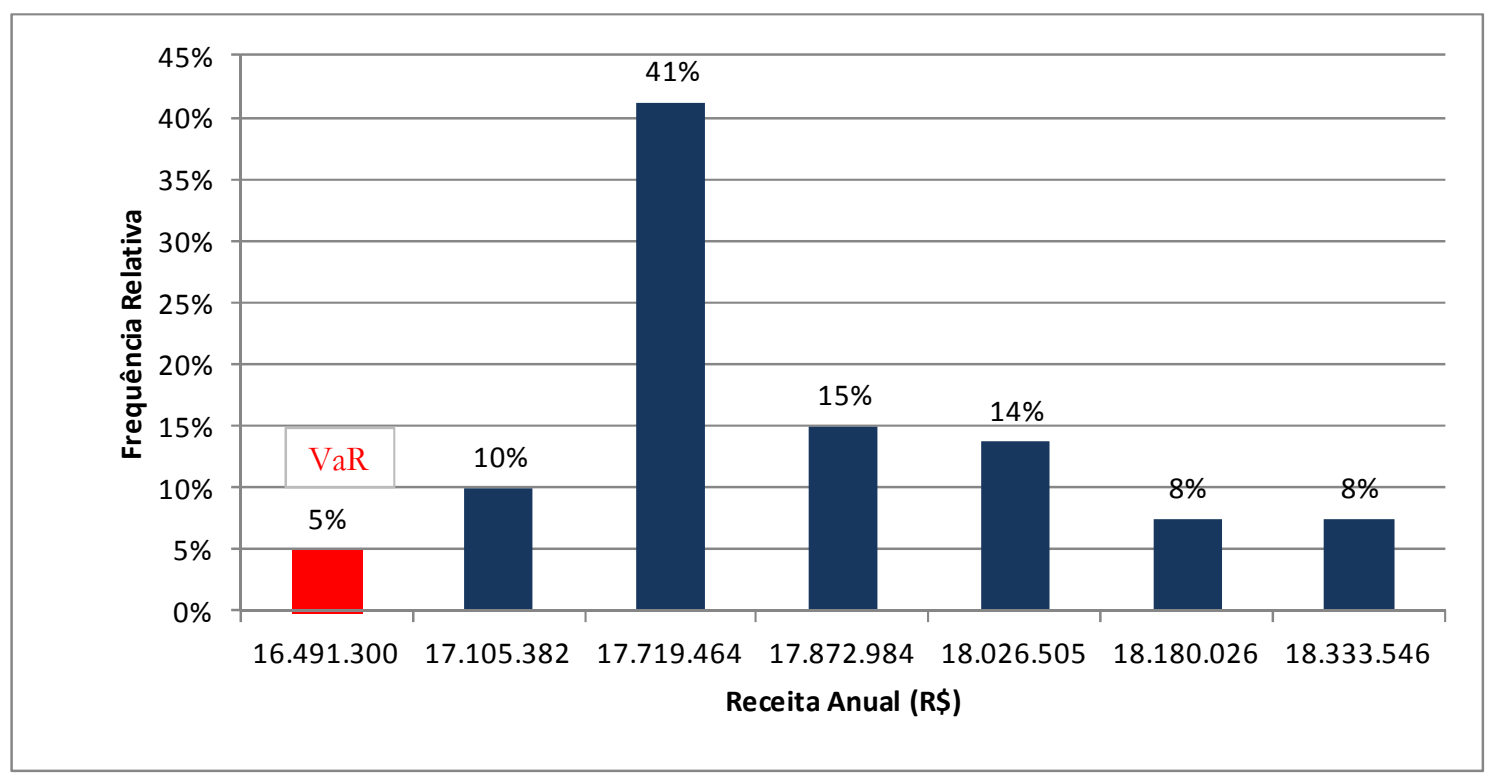

Figura 34 - Distribuição de receitas da Eólica (Fonte: Confecção própria)

\subsection{Um novo negócio: mistura de padrões de produção}

A regulamentação vigente determina que os consumidores livres tenham direito a uma redução de $50 \%$ em suas tarifas de transporte se adquirir energia de fontes eólicas, a biomassa e/ou pequenas centrais hidrelétricas, com potência injetada na rede inferior a 30MW (energia incentivada).

No entanto, o fato de que a maioria dos contratos negociados é por "quantidade", dá origem a uma série de incertezas e riscos do ponto de vista dos produtores. Estes estão sujeitos à perda do desconto na tarifa durante os períodos de indisponibilidade de geração e ficam expostos ao mercado spot, como mencionado antes. Este fato, cabe enfatizar, corrobora a estratégia de montar uma carteira de energia a partir da mistura de padrões de produção.

Desta forma, do ponto de vista do gerador, a complementaridade existente entre fontes incentivadas de produção sazonal, pode ser utilizada para permitir aos agentes maximizar sua receita esperada, sob condicionamento de critérios de risco pré-fixados. Assim, com o objetivo de avaliar e quantificar a sinergia entre eólica e biomassa, que têm perfil de produção complementar às PCHs, foram realizadas simulações para identificar a melhor estratégia de contratação de energia, a fim de buscar a máxima receita líquida possível atendendo a restrições de risco. 
Sob a ótica do comercializador, agente que age basicamente comprando e vendendo contratos de energia elétrica a partir de geradores para vendê-los a outros geradores, comercializadores e consumidores, a proposta é criar um novo modelo de negócio em que este agente compre os direitos de produção da pequena central hidrelétrica, da cogeração de cana e da usina eólica para a venda na forma de um contrato de quantidade de energia firme. A compra da produção é feita por um contrato de capacidade, ou uma opção de compra de energia.

O problema enfrentado pela empresa de comercialização é, então, determinar a quantidade de energia a ser comprada de cada fonte, de forma a equilibrar a maximização do retorno e a minimização do risco de exposição.

Esse esquema de contratação transfere toda a produção e os riscos de entrega dos geradores de energias renováveis para a comercializadora, uma vez que é equivalente alugar $\mathrm{x} \%$ da capacidade de geração disponível e a respectiva percentagem dos montantes GF das fontes, em troca de um fixo "pagamento de capacidade". A quantidade de GF total pode ser revendida aos consumidores por meio de contratos firmes de entrega (contrato de quantidade fixa).

O benefício para a comercializadora é a diferença de preço entre a compra e venda, entretanto a mesma assume os riscos nos cenários de baixa produção de energia, logo este agente deve proteger-se do risco de geração por meio da contratação de um excedente (ou reserva) de capacidade, de modo que o déficit de produção resultante da carteira é atenuado.

De um modo geral, a despesa incorrida pela comercializadora com a compra de capacidade dos agentes de geração é:

Despesa $=\left(P_{P C H} \cdot E_{P C H} \cdot X_{P C H}+P_{B I O} \cdot E_{B I O} \cdot X_{B I O}+P_{E O L} \cdot E_{E O L} \cdot X_{E O L}\right) \cdot h_{t}$

$\mathrm{p} / \mathrm{t}=1, \ldots, \mathrm{T}$

onde,

$P_{P C H}, P_{E O L}, P_{B I O}$ : Preço (em R $\$ / \mathrm{MWh}$ ) exigido por fonte individualmente considerada;

$E_{P C H}, E_{E O L}, E_{B I O}:$ Garantia física em MWm de cada fonte, que desempenham o papel de valor máximo do contrato de cada fonte;

$X_{P C H}, X_{E O L}, X_{B I O}$ : percentual de garantia física e capacidade de produção adquiridos de cada fonte.

$h_{t}$ : número de horas no período t. 
Ao analisar do ponto de vista do gerador, como este é detentor dos ativos, considerou-se nula a despesa, desprezando custos de O\&M e investimento. A receita recebida pela venda de um contrato de quantidade de um determinado montante, definido como $E_{V} \cdot X_{V}$ (em MWm) a um preço $P_{V}$ (em R $\left.\$ / M W h\right)$, válida para ambas as análises:

$$
\begin{aligned}
& \text { Receita }=P_{V} \cdot E_{V} \cdot X_{V} \cdot h_{t} \\
& +\left(G_{t s P C H} \cdot X_{P C H}+G_{t B I O} \cdot X_{B I O}+G_{t s E O L} \cdot X_{E O L}-E_{V} \cdot X_{V}\right) \cdot h_{t} \cdot P L D_{t s} \\
& \mathrm{p} / \mathrm{t}=1, \ldots, \mathrm{T} \text { e } \mathrm{s}=1, \ldots, \mathrm{S}
\end{aligned}
$$

$\mathrm{Na}$ expressão (28), $E_{V}$ representa a energia vendida e $X_{V}$ é variável de decisão, definida no intervalo $0-100 \%$, que expressa o percentual de quantidade que vai ser fornecido.

Além disso, $G_{t s P C H}, G_{t B I O}, G_{t s E O L}$ são os perfis de produção (em MWm), em cada período t, da biomassa, pequenas hidrelétricas e eólicas. Como a PCH foi representada como pertencente ao MRE, considera-se a energia alocada pelo mecanismo ao invés da geração da fonte, $G F_{t P C H} \cdot\left[G_{t s M R E} / G F_{t M R E}\right]$. Plantas hidrelétricas e eólicas (cenário estocástico) estão também submetidas a cenários estocásticos de índice (s), devido à natureza randômica de sua produção. A disponibilidade mensal de cada usina do portfólio é função das características de sazonalização e fator de capacidade de cada uma.

Como mencionado anteriormente, qualquer contrato deve ser lastreado pela garantia física - GF. Dessa forma, a quantidade de energia que poderá ser vendida tem que ser menor ou igual à garantia física somada das fontes que compõem o portfólio de uma geradora ou adquiridos por uma comercializadora. Esta condição (restrição de "não alavancagem") pode ser expressa pela seguinte desigualdade:

$$
E_{V} \cdot X_{V} \leq E_{P C H} \cdot X_{P C H}+E_{B I O} \cdot X_{B I O}+E_{E O L} \cdot X_{E O L}
$$

Vale destacar que o valor de $X_{V}$ é estático, ou seja, nesta abordagem o modelo buscará o percentual ótimo que satisfaça todo o período do contrato, que é coincidente com o horizonte de estudo. No portfólio do gerador, as ponderações $X_{P C H}, X_{B I O}, X_{E O L}$ são iguais a 1 , uma vez que este agente é detentor da integralidade dos ativos. 
O contrato de venda é "flat", ou seja, não há alterações em seu volume ao longo do período analisado. Posteriormente será analisada a precificação de flexibilidades oferecidas aos contratos de venda, bem como o impacto das mesmas na estratégia de contratação.

Em contrapartida, a energia mensal disponível para cobertura do contrato pode variar de um mês para outro, em virtude do perfil de sazonalização de cada fonte. Adicionalmente, o volume da garantia física disponível que é alocada ao contrato de venda também não é fixo, visto que esse parâmetro é a variável no processo de otimização da receita. Dessa forma, em cada período ou mês do estudo, a energia disponível para cobertura do contrato poderá ser diferente do lastro exigido. A diferença apurada em cada período, seja positiva ou negativa, é então valorada ao respectivo PLD. Essa variável é fator determinante na otimização da receita total esperada e está diretamente ligada à complementaridade trazida pela combinação de diversas fontes no portfólio, dada a proteção às variações de PLD às quais uma fonte, quando isolada, pode estar sujeita.

\subsection{Aversão ao risco}

Conforme mencionado anteriormente, para representar o perfil de risco do gerador, escolheu-se as variáveis Value at Risk $(\alpha-\mathrm{VaR})$ e Conditional Value at Risk ( $\alpha-\mathrm{CVaR})$.

Inicialmente, no Estudo de Caso, o risco foi medido através de probabilidade de Receita Líquida Anual abaixo de um valor de receita de referência livre de risco, representada pela alocação de toda a garantia física disponível em um contrato de longo prazo, sem exposições ao mercado de curto prazo. Essa probabilidade deve respeitar dois limites distintos, um superior e um inferior, os quais representam os parâmetros de restrição à otimização da receita.

Foi definido, portanto, que apenas $5 \%$ dos cenários de receita advinda da comercialização de energia de um agente poderiam ser inferiores a $80 \%$ da receita de referência (limite inferior) e até $10 \%$ dos cenários poderiam ser inferiores a $85 \%$ da mesma referência (limite superior).

Posteriormente, na análise do Modelo de Negócio, a restrição aos valores de VaR e CVaR foi o critério de risco utilizado para maximizar o retorno da comercialização da energia produzida pelas fontes, métrica largamente utilizada na otimização de portfólios constituídos por ativos em risco (25). Restringiu-se então o VaR de forma que a Receita Mínima (IC 95\%) fosse maior que 85\% da receita de referência e o CVaR para valores superiores a $80 \%$ da mesma receita de referência. A abordagem utilizada na determinação da quantidade de energia a ser comprada de cada fonte 
foi o modelo de Markowitz para carteiras com mais de dois ativos com risco. Segundo Markowitz a relação entre a taxa de retorno esperado e o risco correspondente a este retorno depende da correlação existente entre os comportamentos dos ativos do portfólio.

Calculou-se então o retorno e o risco para cada ativo, equivalente ao valor esperado e desviopadrão, respectivamente, segundo os preceitos de Markowitz, da distribuição de resultados de venda da garantia física na forma de contrato por quantidade com preço definido e com a valoração dos desvios entre a produção estocástica com perfil sazonal e o montante vendido fixo ao preço spot. Em seguida estabeleceu-se a correlação entre os retornos de cada fonte, para ser possível o cálculo do retorno e risco da carteira e, assim, determinaram-se as ponderações de cada ativo que resultassem em risco mínimo. As equações que subsidiaram este cálculo estão dispostas a seguir:

$$
\begin{gathered}
R_{C}=\left[\begin{array}{llll}
w_{1} & w_{2} & \cdots & w_{n}
\end{array}\right]\left[\begin{array}{c}
R_{1} \\
R_{2} \\
\vdots \\
R_{n}
\end{array}\right] \text { (30) } \\
S_{C}^{2}=\left[\begin{array}{llll}
w_{1} S_{1} & w_{2} S_{2} & \ldots & w_{n} S_{n}
\end{array}\right]\left[\begin{array}{cccc}
\rho_{11} & \rho_{12} & \cdots & \rho_{1 n} \\
\rho_{21} & \rho_{22} & \ldots & \rho_{2 n} \\
\vdots & \vdots & \ddots & \vdots \\
\rho_{n 1} & \rho_{n 2} & \cdots & \rho_{n n}
\end{array}\right]\left[\begin{array}{c}
w_{1} S_{1} \\
w_{2} S_{S} \\
\vdots \\
w_{n} S_{n}
\end{array}\right]
\end{gathered}
$$

Sendo:

- $R_{C}$ o retorno da carteira e $R_{i}$ o retorno do ativo i;

- $S_{C}$ o risco da carteira e $S_{i}$ o risco do ativo i;

- $w_{i}$ a ponderação do ativo i na carteira com a ressalva que $\sum_{i=1}^{n} w_{i}=100 \%$;

- $\rho_{i j}$ a correlação do ativo i em relação ao ativo j. 


\section{ESTUDO DE CASO}

\subsection{Descrição das situações a serem simuladas}

Para se avaliar qual a melhor estratégia de atuação no mercado que possibilite menor risco financeiro possível é preciso simular diferentes composições de parques geradores (portfólios de usinas). Tais simulações devem considerar cada planta geradora comercializando sua Garantia Física de forma independente e de forma conjunta, de tal forma a identificar os potenciais benefícios econômicos traduzidos em maximização de receita.

Supõe-se que geradores e comercializadores sejam capazes de assinarem contratos de venda "por quantidade" com consumidores livres com preço fixado em $\mathrm{R} \$ 140,00 / \mathrm{MWh}$ pelo período de 4 anos (2014-2017).

Serão realizadas duas análises, a primeira do ponto de vista do gerador, detentor de ativos de pequenas centrais hidrelétricas, usinas eólicas e de biomassa, todas com capacidade instalada de 30 MW. Desse modo, o objetivo será maximizar a receita da venda da garantia física das três fontes, para um determinado critério de risco, por meio da definição do montante de energia disponibilizado para contratação, valorando os desvios entre geração e o contrato de venda firmado (exposições) ao preço spot.

A segunda análise foca-se no comercializador, que firmará contratos de capacidade com pequenas centrais hidrelétricas, usinas eólicas e de biomassa ao preço de $\mathrm{R} \$ 115,00 / \mathrm{MWh}$, de forma que as proporções de cada fonte em seu portfólio sejam tais que minimizem o risco do agente. Em seguida será definido o valor de energia para contratação de maneira análoga ao descrito na primeira análise.

A formulação estocástica do problema requer um conjunto de cenários de preços spot (PLD), geração hidrelétrica e energia alocada do MRE para modelar as incertezas presentes no problema, e uma amostra de 81 cenários de preços e geração mensais (baseados nos valores históricos de vazões) foram obtidas, a partir do resultado do modelo Newave do Programa Mensal da Operação de dezembro de 2013, para um horizonte temporal de 4 anos. As condições iniciais do sistema eram armazenamento equivalente a 42,7\% da capacidade máxima ao início de 2014. 
A geração da usina eólica foi considerada determinística e equivalente a média mensal do histórico de três anos de medição de um sítio eólico no Estado do Ceará. Nesse caso, o perfil de sazonalização anual é repetido para todo o horizonte de estudo e para cada série histórica de afluência. A oportunidade de negócio leva em consideração a sazonalidade por meio da composição mensal da receita total.

Considerou-se que as fontes de geração hidrelétrica, eólica e de biomassa têm $30 \mathrm{MW}$ de capacidade instalada e 19,5, 14,24 e 14,40 MW Médios de Garantia Física, respectivamente. Os montantes de Garantia Física constituem o máximo valor a ser disponibilizado à contratação.

\subsection{Análise I - Portfólio de um Gerador - Resultados}

$\mathrm{Na}$ tabela 4 estão as características das fontes de geração que poderão compor o portfólio do gerador:

\begin{tabular}{llccc} 
Fonte & Tabela 4 - Projetos Possiveis para Composição do Portfólio \\
PCH & BIO & EOL \\
\hline Potência & MW & 30 & 30 & 30 \\
\hline Garantia Física & MWm & 19,50 & 14,40 & 14,24
\end{tabular}

A seguir, através da Figura 35, tem-se o gráfico resultante da simulação do portfólio combinado das três fontes, no qual é possível analisar a evolução das linhas de receita e de risco conforme o percentual de garantia física disponibilizado à contratação varia. A linha pontilhada vermelha no gráfico indica o limite inferior e a linha pontilhada verde indica o limite superior, cujo eixo de referência está disposto à direita. Em termos visuais, o gráfico induz que o problema tem solução na região de intersecção caracterizada por (i) linha verde contínua de probabilidade de receita abaixo de $85 \%$ dentro da área delimitada pelo eixo horizontal e a linha tracejada verde, e simultaneamente (ii) linha vermelha contínua de probabilidade de receita abaixo de $80 \%$ situada dentro da área delimitada pelo eixo horizontal e a linha tracejada vermelha, o que significa que os valores de probabilidade de receita abaixo de $85 \%$ e $80 \%$ da receita de referência, linhas contínuas verde e vermelha, atendem aos limites superior (10\%) e inferior (5\%) de probabilidade, respectivamente. 


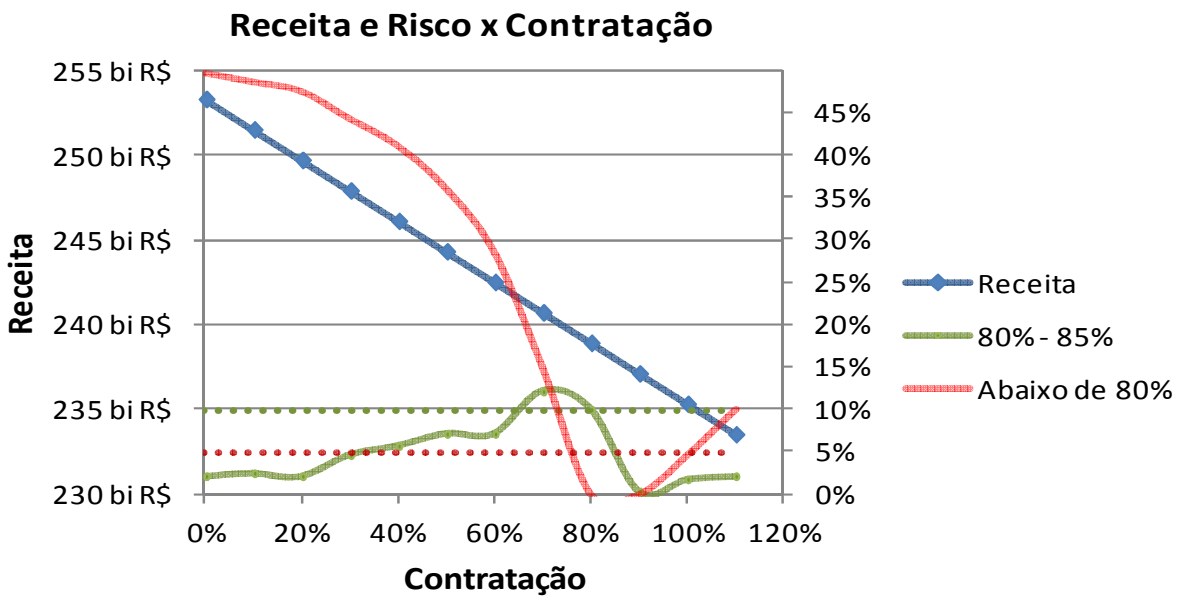

Figura 35 - Receita/Risco de Contrataşão - PCH+EÓLICA+BIOMASSA - 2014 - 2017

(Fonte: Confecção própria)

Tabela 5 - Resumo dos Resultados da Otimização

\begin{tabular}{|c|c|c|c|c|c|c|}
\hline \multirow[b]{2}{*}{ Usinas } & \multirow[b]{2}{*}{$\begin{array}{c}\text { Volume } \\
\text { Total (MWm) }\end{array}$} & \multirow{2}{*}{$\begin{array}{c}\text { Contratação } \\
\text { Ótima }\end{array}$} & \multicolumn{2}{|c|}{ Receita Ótima - R\$MM } & \multirow{2}{*}{$\begin{array}{l}\text { Hedge } \\
\mathrm{R} \$ \text { mil }\end{array}$} & \multirow{2}{*}{$\begin{array}{c}\text { Receita } \\
\mathrm{R} \$ / \mathrm{MWh}\end{array}$} \\
\hline & & & $\begin{array}{l}\text { Operação } \\
\text { Conjunta } \\
\end{array}$ & $\begin{array}{c}\text { Operação } \\
\text { Isolada }\end{array}$ & & \\
\hline EOL & 14,24 & $80,75 \%$ & - & $\mathrm{R} \$ 71,54$ & - & 177,4 \\
\hline $\mathrm{PCH}$ & 19,5 & $78,68 \%$ & - & $R \$ 93,38$ & - & 173,6 \\
\hline BIOMASSA & 14,4 & $81,10 \%$ & - & $\mathrm{R} \$ 73,99$ & - & 180,7 \\
\hline $\mathrm{EOL}+\mathrm{PCH}$ & 33,74 & $78,66 \%$ & $\mathrm{R} \$ 165,03$ & $\mathrm{R} \$ 164,92$ & $\mathrm{R} \$ 113,61$ & 177,3 \\
\hline EOL+BIOMASSA & 28,64 & $80,75 \%$ & $\mathrm{R} \$ 145,56$ & $\mathrm{R} \$ 145,54$ & $\mathrm{R} \$ 19,10$ & 179,5 \\
\hline $\mathrm{PCH}+$ BIOMASSA & 33,9 & $78,34 \%$ & $\mathrm{R} \$ 167,54$ & $\mathrm{R} \$ 167,37$ & $R \$ 173,75$ & 179,9 \\
\hline $\mathrm{PCH}+\mathrm{BIOMASSA}+\mathrm{EOL}$ & 48,14 & $78,80 \%$ & $\mathrm{R} \$ 239,13$ & $R \$ 238,91$ & $R \$ 220,19$ & 179,8 \\
\hline
\end{tabular}

A simulação mostra que no caso da pequena central hidrelétrica, a operação isolada só é possível se a mesma pertencer ao Mecanismo de Realocação de Energia - MRE. Caso esta usina opere fora deste mecanismo, não é possível atender às condições de risco e, portanto, não se considerou esta opção nos resultados. Além disso, fica nítido o "hedge" que as fontes têm entre si e os benefícios que os investidores encontram quando exploram a sinergia entre estas fontes.

Nota-se que o portfólio com maior retorno em média, em $\mathrm{R} \$ / \mathrm{MWh}$, é composto apenas pela planta a biomassa. Entretanto, o risco incorrido pelo empreendedor ao apostar nesta configuração inviabiliza esta opção. Observou-se na figura, que se não houvesse a limitação de risco financeiro, a maximização de receita seria obtida com a disponibilização da totalidade da energia das usinas ao mercado spot, pois o preço de contrato assumido é inferior à média do preço spot, considerando todas as séries hidrológicas e anos do horizonte de análise. No entanto têm-se situações de receitas muito reduzidas em longos períodos em que o preço spot é baixo (períodos hidrológicos favoráveis). 
Verificou-se que a melhor estratégia para atendimento às restrições e ao mesmo tempo para maximizar a receita é disponibilizar cerca de $80 \%$ da garantia física somada dos empreendimentos para contratação. Assim, a redução do percentual de contratação, buscando melhorar a expectativa de receita, implica em violar a restrição de receita mínima entre 80 e $85 \%$ da receita de referência.

Os parâmetros de risco obtidos desta análise indicam que não há cenários de receita negativa na estratégia escolhida e apontam um desvio pouco significativo entre o valor de retorno esperado e a média dos piores cenários de receita, conforme observado na tabela e ilustração dispostas abaixo.

Tabela 6 - Resultados Financeiros e Parâmetros de Risco

\begin{tabular}{cccc} 
Tipo de Solução & $\begin{array}{c}\text { Retorno } \\
\text { Esperado }\end{array}$ & VaR & CVaR \\
& R\$ MM & R \$ MM & R M MM \\
\hline Averso ao Risco & 237,2 & 205,4 & 202,4
\end{tabular}

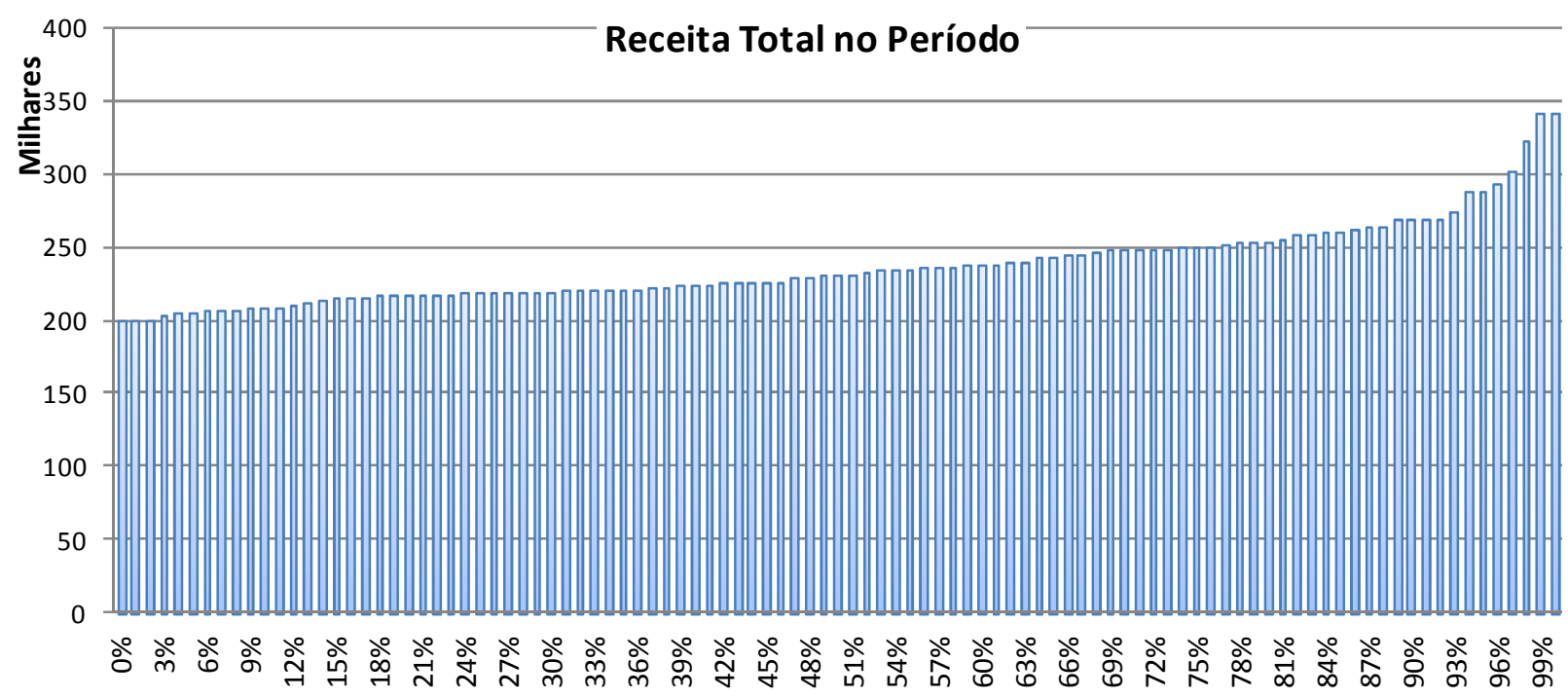

Figura 36 - Função de probabilidade acumulada inversa da receita no período de 4 anos para o portfólio de $P C H+B I O+E O L$ (Fonte: Confecção própria)

O estudo da sazonalização da Garantia Física das usinas em função dessa sinergia, determina quais estratégias devem ser adotadas para maximizar os retornos ou para proteção (hedge) contra riscos de geração (28). Esta avaliação está contemplada no capítulo de Modelo de Negócio desta dissertação. 


\subsection{Análise II - Portfólio de um Comercializador - Resultados}

\subsubsection{Análise neutra ao risco}

É obtida por meio da maximização do retorno da carteira de Markowitz, sem restrição ao valor de risco. Resultou em um portfólio composto integralmente por cogeração a biomassa. Isto devido à relação vantajosa que existe entre o perfil de geração da usina de biomassa e os valores esperados de preço spot, ou seja, os períodos em que a geração de biomassa é baixa coincidem com os períodos de maior geração hidrelétrica, resultando em preços spot baixos, o contrário também é válido.

Para este caso considerou-se a compra de 10 MW Médios de capacidade de geração da biomassa e a correspondente venda do mesmo montante de forma "flat". Como resultado tem-se um ganho médio de R\$ 10,6 MM no período de 2014 a 2017, devido à sua produção de energia sazonal. No entanto, o valor de $\mathrm{CVaR}, \mathrm{R} \$$ - 3,5 MM, revela as perdas potenciais desta carteira.

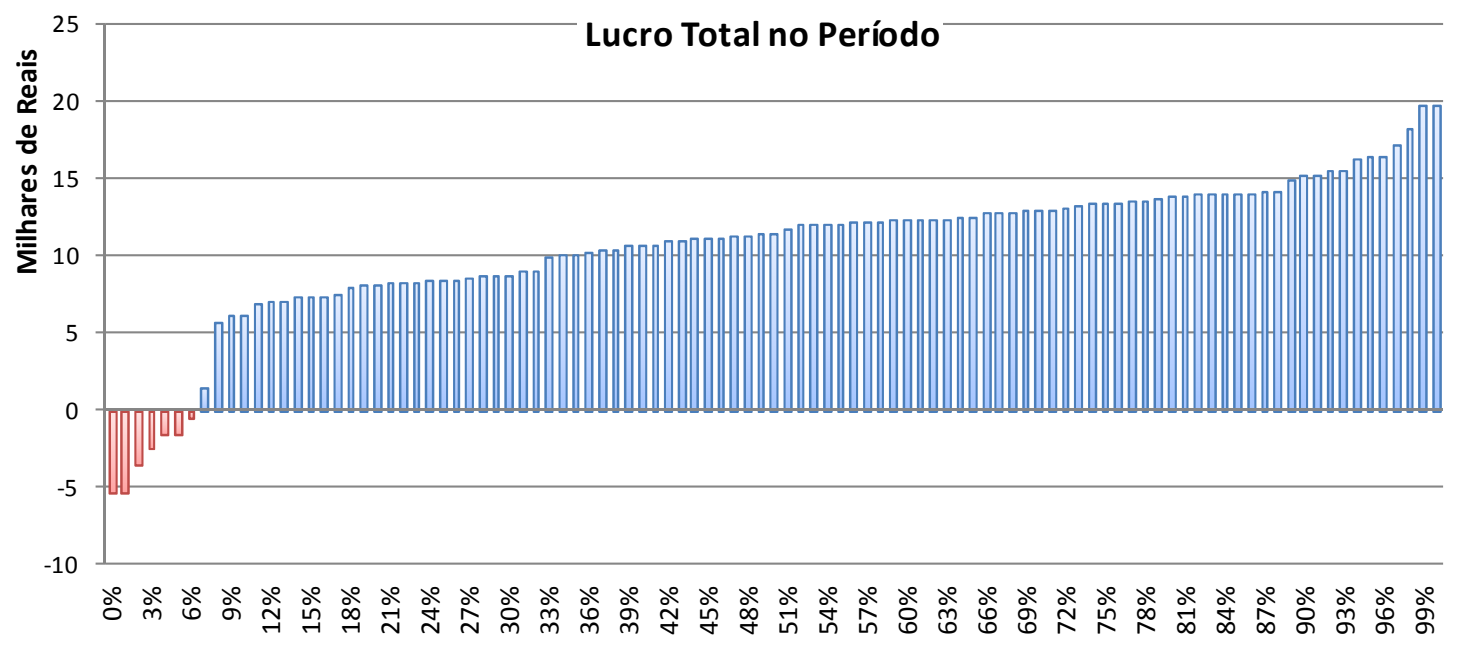

Figura 37 - Função de probabilidade acumulada inversa do lucro no período de 4 anos, resultante da carteira neutra ao risco (Fonte: Confecção própria)

As perdas potenciais para os piores cenários de 5\% sugerem a necessidade de uma restrição de risco que requer uma receita líquida mínima como limite inferior para este conjunto de cenários. Isto é feito quando se determina a composição da carteira que resulte em risco mínimo. 


\subsubsection{Análise de aversão ao risco}

A carteira de risco mínimo resultou por uma mistura entre as fontes de geração hidrelétrica e eólica, excluindo do resultado a compra de capacidade de usinas a biomassa pelo agente comercializador. Este resultado é razoável, pois a correlação dos retornos de comercialização de geração da pequena central hidrelétrica e da usina eólica é a mais negativa dentre as combinações de fontes de geração. O que significa que a complementaridade das duas fontes é mais acentuada, implicando em menor exposição e, consequentemente, em menor risco.

De forma a atender o mesmo contrato de venda "flat" de $10 \mathrm{MWm}$, a estratégia avessa ao risco resultou na compra de 8,6 MWm e 1,4 MWm de capacidade de geração de pequenas centrais hidrelétricas e de eólicas, respectivamente.

\section{Tabela 7 - Volumes de Energia Contratados}

\begin{tabular}{lccccc} 
Tipo de Solução & $\mathrm{E}_{\mathrm{V}} \cdot \mathrm{x}_{\mathrm{V}}$ & $\mathrm{E}_{\mathrm{PCH} .} . \mathrm{X}_{\mathrm{PCH}} \mathrm{E}_{\mathrm{EOL}} . \mathrm{X}_{\mathrm{EOI}} \mathrm{E}_{\mathrm{BIO} .} \mathrm{X}_{\mathrm{BIO}}$ & $\begin{array}{c}\text { Energia } \\
\text { Comprada } \\
\mathrm{MWm}\end{array}$ \\
\hline Neutro ao Risco & $\mathrm{MWm}$ & $\mathrm{MWm}$ & $\mathrm{MWm}$ & $\mathrm{MWm}$ & $\mathrm{MWm}$ \\
Averso ao Risco & 10,0 & 0,0 & 0,0 & 10,0 & 10,0 \\
& 10,0 & 8,6 & 1,4 & 0,0 & 10,0
\end{tabular}

Tabela 8 - Resultados Financeiros e Parâmetros de Risco

\begin{tabular}{lccc} 
Tipo de Solução & $\begin{array}{c}\text { Retorno } \\
\text { Esperado } \\
\mathrm{R} \$ \mathrm{MM}\end{array}$ & $\begin{array}{c}\mathrm{VaR} \\
\mathrm{R} \$ \mathrm{MM}\end{array}$ & $\begin{array}{c}\mathrm{CVaR} \\
\mathrm{R} \$ \mathrm{MM}\end{array}$ \\
\hline Neutro ao Risco & 10,6 & $-1,5$ & $-3,5$ \\
Avesso ao Risco & 8,5 & 8,0 & 7,9
\end{tabular}

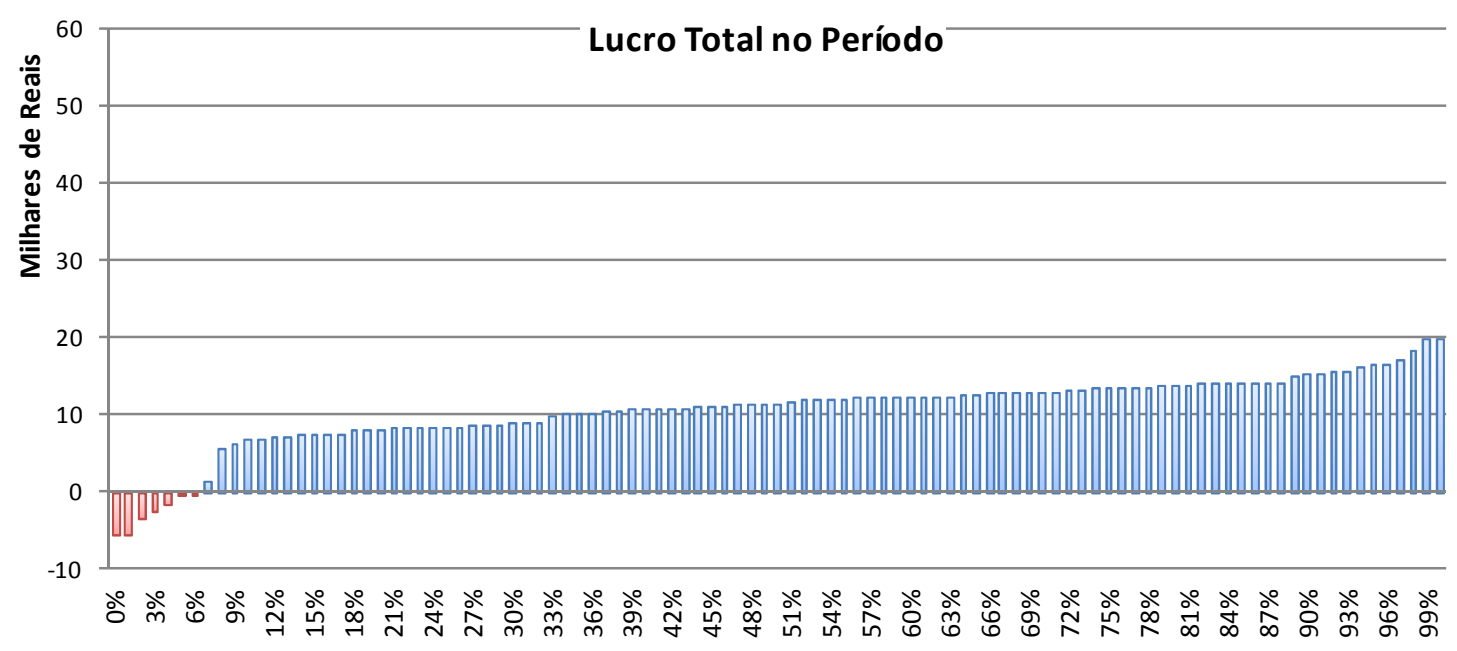

Figura 38 - Função de probabilidade acumulada inversa do lucro no período de 4 anos, resultante da carteira neutra ao risco (Fonte: Confecção própria) 


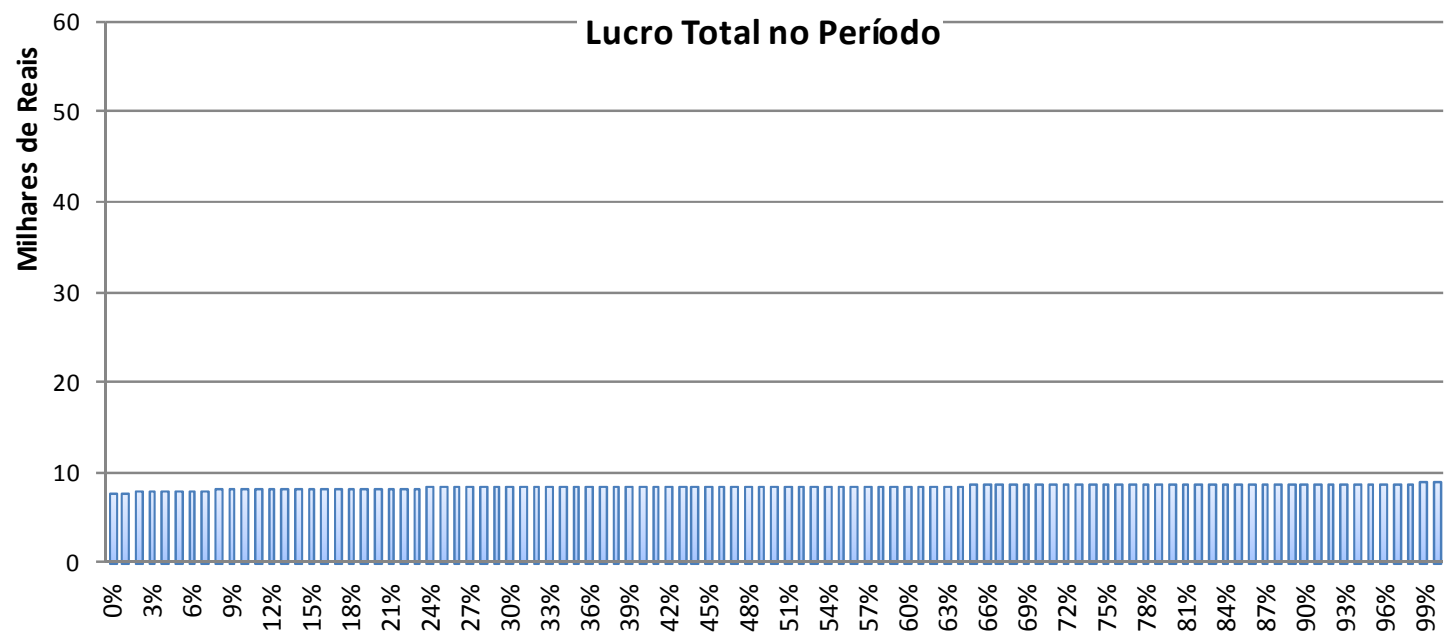

Figura 39 - Função de probabilidade acumulada inversa do lucro no período de 4 anos, resultante da carteira avessa ao risco (Fonte: Confecção própria)

Na Tabela 8, o retorno esperado para a solução avessa ao risco é menor do que para a carteira neutra ao risco, o que é a consequência das restrições impostas de limitação do risco.

Percebe-se que o comercializador de energia pode lucrar neste negócio, considerando o nível de risco razoável, formando uma carteira de aversão ao risco que compreende uma combinação ótima de fontes de energia renováveis.

Quando se aplica a avaliação do nível ótimo de Garantia Física das fontes hidráulica e eólica disponibilizada para a contratação, de acordo com os critérios de restrição da receita mínima combinados à maximização do retorno da comercialização da energia, tem-se um resultado ainda mais robusto em termos de ganho em receita esperada, a qual passa a ser $\mathrm{R} \$ 11 \mathrm{MM}$ e as variáveis VaR e CVaR R \$1,9 MM e R \$1,1MM, respectivamente.

Tabela 9 - Volumes de Energia Contratados

Tipo de Solução

$$
\mathrm{E}_{\mathrm{V}} \cdot \mathrm{x}_{\mathrm{V}} \mathrm{E}_{\mathrm{PCH}}, \mathrm{X}_{\mathrm{PCH}} \mathrm{E}_{\mathrm{EOL}}, \mathrm{X}_{\mathrm{EOI}} \mathrm{E}_{\mathrm{BIO}}, \mathrm{X}_{\mathrm{BIO}}
$$

Energia

Comprada

\begin{tabular}{lccccc} 
& MWm & MWm & MWm & MWm & MWm \\
\hline Neutro ao Risco & 10,0 & 0,0 & 0,0 & 10,0 & 10,0 \\
Averso ao Risco & 10,0 & 8,6 & 1,4 & 0,0 & 10,0 \\
Averso ao Risco + Nível & 10,0 & 10,9 & 1,8 & 0,0 & 12,7 \\
Ótimo de Contratação & & & &
\end{tabular}


Tabela 10 - Resultados Financeiros e Parâmetros de Risco

\begin{tabular}{lccc} 
Tipo de Solução & $\begin{array}{c}\text { Retorno } \\
\text { Esperado } \\
\mathrm{R} \$ \mathrm{MM}\end{array}$ & $\begin{array}{c}\text { VaR } \\
\mathrm{R} \$ \mathrm{MM}\end{array}$ & $\begin{array}{c}\mathrm{CV} \text { RR } \\
\mathrm{R} \text { MM }\end{array}$ \\
\hline Neutro ao Risco & 10,6 & $-1,5$ & $-3,5$ \\
$\begin{array}{l}\text { Avesso ao Risco } \\
\text { Avesso ao Risco + Nível }\end{array}$ & 8,5 & 8,0 & 7,9 \\
Ótimo de Contratação & 11,0 & 1,9 & 1,1
\end{tabular}

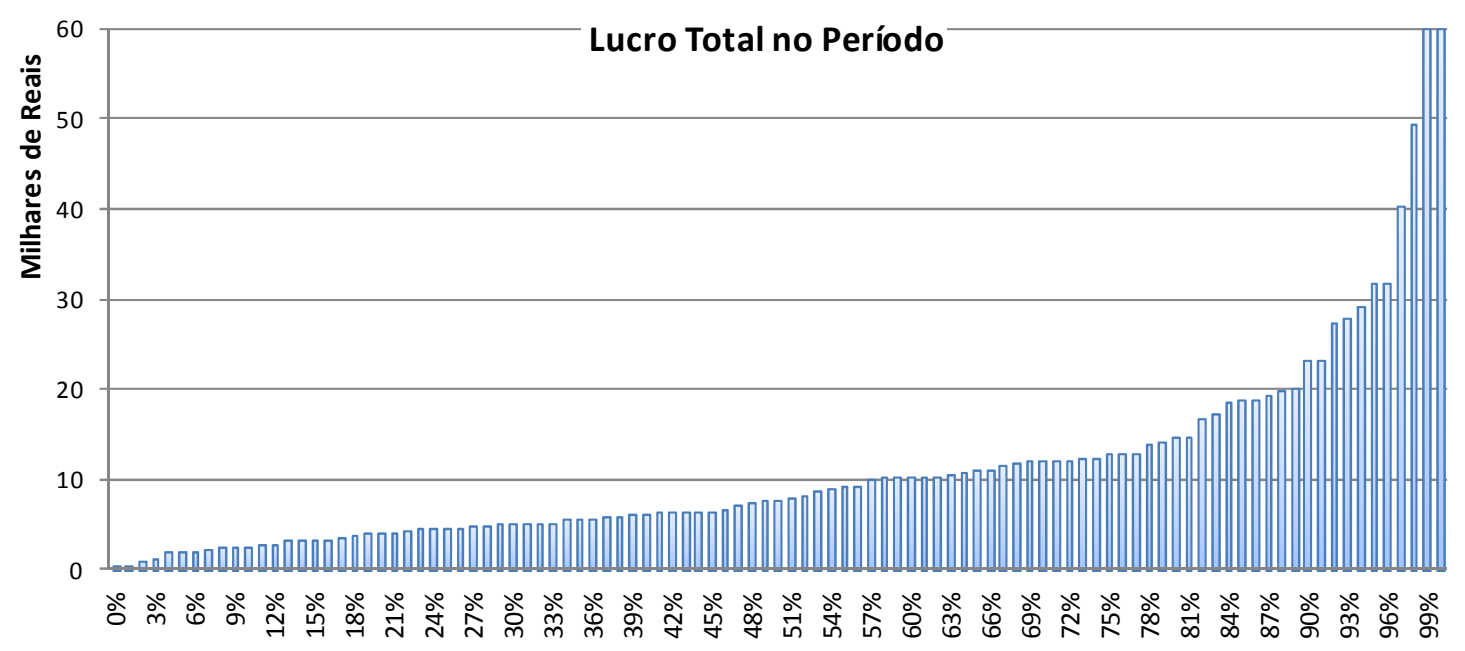

Figura 40 - Função de probabilidade acumulada inversa do lucro no período de 4 anos, resultante da carteira avessa ao risco com nivel de contratação ótimo (Fonte: Confecção própria) 


\section{CONSIDERAÇÃO DOS FATORES DE RISCO DE MERCADO}

Neste capítulo os fatores de risco dos contratos, tais como flexibilidade, sazonalidade e oriundo da venda de energia em subsistema diferente do local de geração, são modelados e precificados, de forma a acrescentar uma margem de risco ao preço final de venda, fazendo com que seja indiferente, dado um critério de risco, realizar um contrato de venda de energia sem o fator de risco a um preço $\mathrm{X} R \$ / \mathrm{MWh}$ e vender com o fator de risco a um preço $\mathrm{X}+\mathrm{M}(\mathrm{R} \$ / \mathrm{MWh})$.

A modelagem é feita por meio de simulação de Monte Carlo, a qual efetua análise de risco por meio da construção de modelos de possíveis resultados, substituindo com um intervalo de valores - uma distribuição de probabilidade - todo fator com incerteza inerente. Em seguida, calcula-se os resultados repetidamente, cada vez com outro conjunto de valores aleatórios gerados por funções de probabilidades. Ao usar distribuições de probabilidade, as variáveis podem apresentar diferentes probabilidades de ocorrência de diferentes resultados, uma forma muito mais realista de descrever incerteza em variáveis de análises de risco. Durante uma simulação, as amostras dos valores são obtidas aleatoriamente das distribuições de probabilidade de inputs (entradas). Cada conjunto de amostra é chamada de iteração, e o resultado produzido a partir da amostra é registrado. A simulação de Monte Carlo faz isso centenas ou milhares de vezes, e o produto disso é uma distribuição de probabilidade dos resultados possíveis. Dessa forma, a simulação de Monte Carlo fornece um quadro muito mais abrangente do que poderá acontecer, assim como a probabilidade de ocorrência.

Estruturou-se a precificação destes riscos considerando contrato de venda de R $\$ 180 / \mathrm{MWh}$ nas condições atuais do sistema interligado, com níveis de armazenamento no início do ano de 2015 na ordem de $20 \%$ da capacidade para o período 2015-2019.

\subsection{Risco associado à Flexibilidade dos contratos}

A flexibilidade representa a possibilidade de variações no montante mensal do contrato para adequá-lo ao real consumo de energia do cliente. Para cada período de fornecimento, será permitida uma variação mensal pré-definida, em relação à quantidade de energia contratada expressa em MW médios, baseada na energia medida ajustada (energia medida acrescida de fator de perda de 3\%) da unidade de consumo. 
Em caso de ultrapassagem dos valores definidos como flexibilidade o cliente fica exposto ao mercado de curto prazo.

\section{Modelagem:}

Como o comportamento do consumidor não é previamente conhecido, o exercício da flexibilidade será modelado como uma distribuição uniforme, onde cada valor ao longo da faixa da distribuição possui probabilidade igual de ocorrência.

O resultado considera o intervalo de confiança de $95 \%$ e mede o risco de perda financeira em função de cenários desfavoráveis de exercício de flexibilidade e a valoração deste risco considera diferenças de preços do contrato e preços de contratos de curto prazo.

Risco $_{\text {Flexibilidade }}=\left(\right.$ Volume $_{\text {Contratado Flat }}-\left(1 \pm\right.$ Flexibilidade $\left._{(\%)}\right) \times$ Volume $\left._{\text {Contratado Flat }}\right) x\left(\right.$ Preço Venda $\left._{\text {Vla }}-P L D\right)$

No entanto, há ainda o exercício da flexibilidade de forma correlacionada ao preço de curto prazo. Sempre que o PLD estiver alto ou acima do preço do contrato, a flexibilidade exercida será a máxima, pois a contraparte terá o excedente de energia liquidado no mercado de curto prazo e pagará por ele o preço de contrato, que neste caso é inferior ao PLD.

O contrário também é válido, ou seja, quando o PLD estiver baixo ou inferior ao preço de contrato a flexibilidade exercida será a mínima, pois o desvio entre o volume contratato e o entregue será adquirido no mercado de curto prazo a um preço inferior.

Do ponto de vista do vendedor, tal opção implica em prejuízo certo, pois o exercício de flexibilidade máxima sempre que o PLD estiver superior ao preço de venda, implica em contratar o volume a mais solicitado no mercado de curto prazo, desembolsando a diferença entre preço spot e o contratado. No caso em que o exercício da flexibilidade é mínimo, implica em vender no mercado de curto prazo o volume não entregue a um preço muito inferior ao de venda.

No trabalho proposto, considerou-se a venda diretamente a consumidores finais, de forma que o exercício da flexibilidade seja atrelado ao consumo e, modelado, portanto, como uma variável aleatória. 
A tabela abaixo indica a perda de receita máxima, dado o nível de confiança de $95 \%$, em $\mathrm{R} \$ / \mathrm{MWh}$, que o vendedor está sujeito ao fornecer este atributo ao comprador. Deve-se adicionar este valor ao preço de venda, de forma a anular o impacto da flexibilidade na carteira.

Tabela 11 - Risco associado ao exerćício da flexibilidade precificado considerando o P5\% (R\$/MWh)

\begin{tabular}{cc}
\multicolumn{2}{c}{ Flexibilidade (P95\%) - $\mathbf{R} \mathbf{\text { MWh }}$} \\
\hline \% de Flex & $\mathbf{2 0 1 5 - 2 0 1 9}$ \\
\hline $\mathbf{1 0} \%$ & $-1,83$ \\
$\mathbf{1 5 \%}$ & $-2,74$ \\
$\mathbf{2 0} \%$ & $-3,63$ \\
$\mathbf{2 5} \%$ & $-4,60$ \\
$\mathbf{3 0} \%$ & $-5,44$ \\
\hline
\end{tabular}

\subsection{Risco associado a diferenças de preços entre submercados}

O risco de submercado ocorre quando o preço spot (PLD) do submercado de geração ou compra de energia é diferente do preço do submercado de entrega da energia contratada (vendida). Representa a possibilidade de diferenças de preços entre os submercados e ocorre em situações em que a transferência de energia é limitada pela capacidade do sistema de transmissão, havendo então a necessidade de despachar geradores térmicos de maior custo no submercado importador para atender aumentos de demanda.

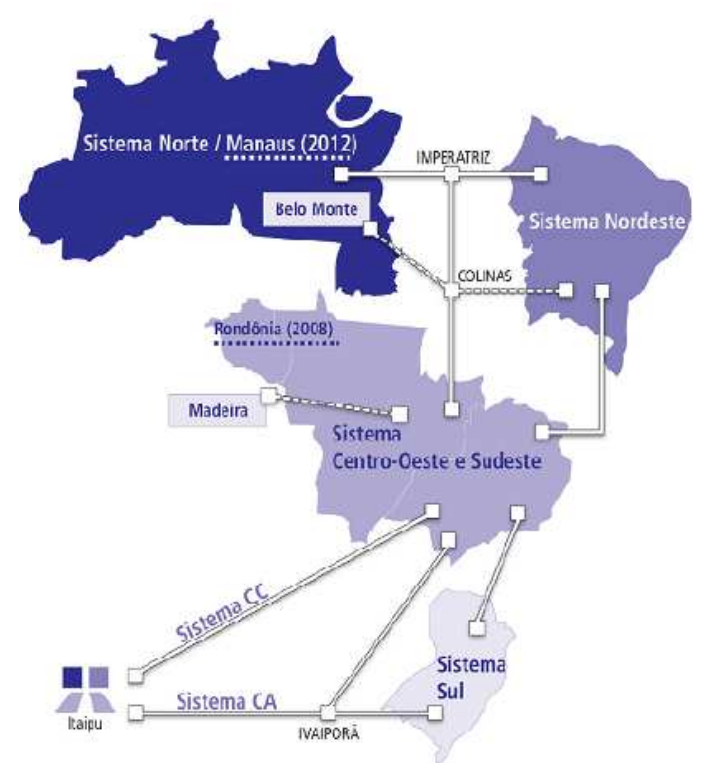

Figura 41 - Limite de intercâmbio entre submercados (Fonte(1)) 
A capacidade de intercâmbio energético entre regiões é limitada, gerando as diferenças nos PLDs de cada submercado. Tais preços refletem o equilíbrio entre a oferta e demanda de energia elétrica em determinado submercado. Dado que um contrato bilateral de energia pode ser feito em qualquer submercado, o risco da diferença de preços entre submercado, quando existir, deve ser negociado na contratação.

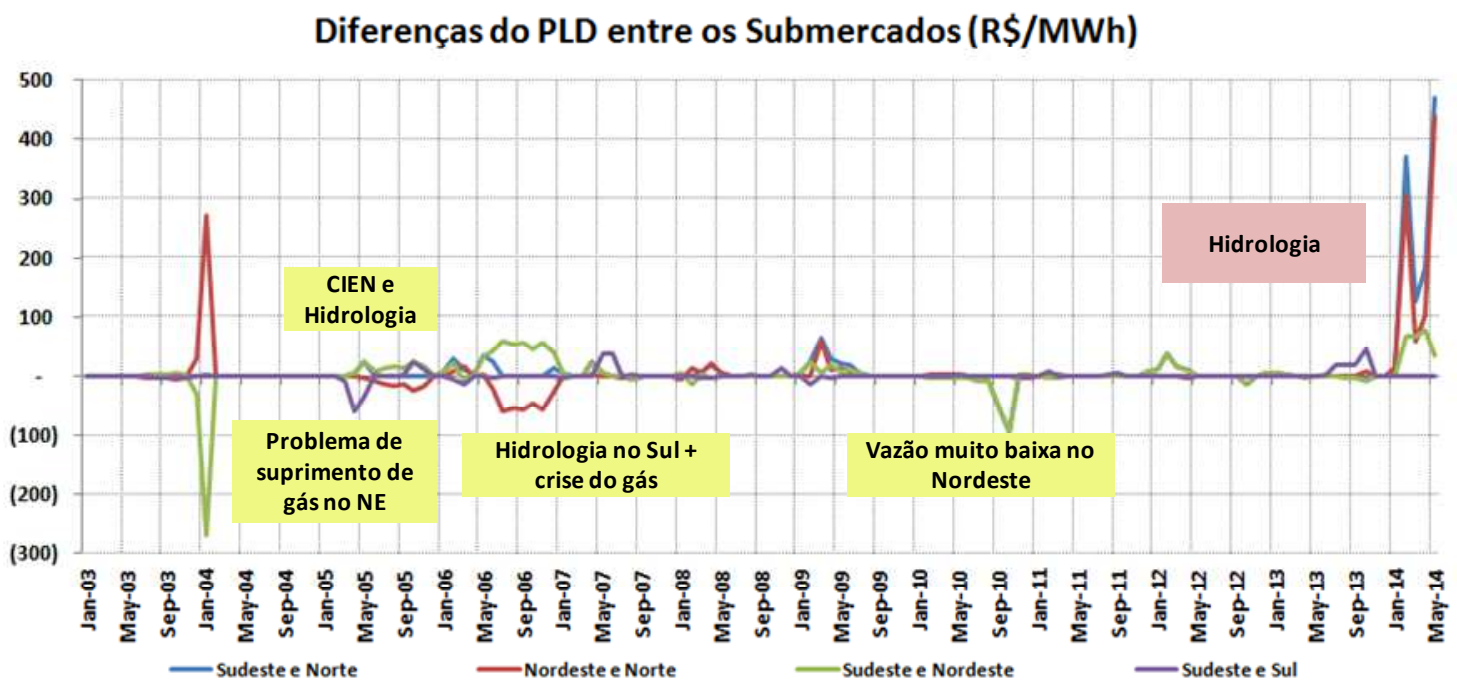

Figura 42 - Diferenças de PLD entre Submercados (Fonte: Confecção própria)

\section{Modelagem:}

A modelagem desse risco é feita comparando-se os preços de liquidação das diferenças (PLD) do submercado do comprador com os preços do submercado da geração ou dos contratos de compra. A diferença de preço é aplicada então ao volume em MWh. Sempre que o PLD do submercado do vendedor é inferior ao PLD do submercado do comprador há perda para quem assume este risco, nos cenários em que o PLD do subsistema do vendedor é superior ao do comprador há ganhos.

O resultado considera o intervalo de confiança de $95 \%$ e mede o risco de perda financeira em função de cenários desfavoráveis da combinação destes preços.

Há a possibilidade do risco de submercado apresentar ganhos na maioria dos cenários sorteados, por exemplo, se a venda de energia for em submercado com PLD inferior ao submercado de geração ou de compra. Neste caso, foi convencionado que tal risco não deveria ser adicionado na 
análise e sim avaliado de maneira individual, sem a necessidade de margem adicional ao preço por MWh.

$\mathrm{Na}$ tabela a seguir estão expostos os riscos associados à diferença de preço entre o submercado de origem da energia (geração ou contrato de compra) e de destino da energia (venda). Valores negativos representam perdas e positivos se traduzem em ganhos.

A total mitigação deste risco pode ser feita adicionando um valor equivalente ao máximo risco incorrido (percentil 5\%) ao preço de venda final.

$\mathrm{Na}$ análise do modelo de negócio a seguir, consideraremos um portfólio composto por fonte hidrelétrica e de cogeração a biomassa no subsistema sudeste e eólica no nordeste. Assim, uma venda que representa uma entrega de energia no submercado sudeste possui risco associado à diferença de preços entre os submercados nordeste e sudeste no montante produzido pela fonte eólica.

Este impacto, no horizonte 2015-2019, adiciona um risco máximo de R \$ 47,82/MWh relacionado a geração da usina eólica no Nordeste e sua venda no Sudeste. Isto porque o submercado Nordeste possui a longo prazo sobra estrutural de energia (oferta maior que a demanda), caracterizando-se por exportador de energia, principalmente para o sudeste e, portanto, terá preços no mercado de curto prazo mais baixos.

Tabela 12 - Risco associado à diferença de preço entre os submercados $(\mathrm{R} \$ / M W h)$

Risco associado a diferença de preço entre os submercados Sudeste e Sul ( $\mathbf{R}$ / MWh)

\begin{tabular}{|c|c|c|c|c|c|c|c|c|c|c|c|c|}
\hline \multirow[t]{2}{*}{ Compra/ Venda } & \multicolumn{2}{|c|}{2015} & \multicolumn{2}{|c|}{2016} & \multicolumn{2}{|c|}{2017} & \multicolumn{2}{|c|}{2018} & \multicolumn{2}{|c|}{2019} & \multicolumn{2}{|c|}{ 2015-2019 } \\
\hline & Esperado & 5,10 & Esperado & $-0,31$ & Esperado & $-0,35$ & Esperado & 1,20 & Esperado & 1,47 & Esperado & 1,42 \\
\hline \multirow{4}{*}{ Sudeste/ Sul } & P5\% & $-3,24$ & P5\% & $-20,78$ & P5\% & $-5,81$ & P5\% & $-1,12$ & P5\% & $-1,80$ & P5\% & $-6,55$ \\
\hline & P20\% & $-0,25$ & P20\% & $-1,49$ & P20\% & $-1,13$ & P20\% & $-0,46$ & P20\% & $-0,37$ & P20\% & $-0,74$ \\
\hline & P80\% & 12,43 & $\mathbf{P} 80 \%$ & 4,72 & P80\% & 3,71 & P80\% & 2,63 & P80\% & 2,62 & P80\% & 5,22 \\
\hline & P95\% & 21,54 & P95\% & 12,59 & P95\% & 10,12 & P95\% & 6,05 & P95\% & 7,03 & P95\% & 11,47 \\
\hline
\end{tabular}

Risco associado a diferença de preço entre os submercados Sudeste e Nordeste ( $\mathrm{R} \$ \mathbf{M W h}$ )

\begin{tabular}{|c|c|c|c|c|c|c|c|c|c|c|c|c|}
\hline Compra/ Venda & \multicolumn{2}{|c|}{2015} & \multicolumn{2}{|c|}{2016} & \multicolumn{2}{|c|}{2017} & \multicolumn{2}{|c|}{2018} & \multicolumn{2}{|c|}{2019} & \multicolumn{2}{|c|}{$2015-2019$} \\
\hline \multirow{5}{*}{ Sudeste/ Nordeste } & Esperado & 8,46 & Esperado & 12,81 & Esperado & 15,01 & Esperado & 7,88 & Esperado & 8,26 & Esperado & 10,48 \\
\hline & P5\% & $-2,67$ & P5\% & $-0,10$ & P5\% & 0,00 & P5\% & 0,00 & P5\% & 0,00 & P5\% & $-0,55$ \\
\hline & $\mathbf{P} 20 \%$ & $-0,04$ & $\mathbf{P} 20 \%$ & 0,00 & $\mathbf{P} 20 \%$ & 0,45 & $\mathbf{P} 20 \%$ & 0,00 & $\mathbf{P} 20 \%$ & 0,00 & $\mathbf{P} 20 \%$ & 0,08 \\
\hline & $\mathbf{P} 80 \%$ & 9,97 & $\mathbf{P} 80 \%$ & 18,27 & $\mathbf{P} 80 \%$ & 22,51 & $\mathbf{P} 80 \%$ & 9,10 & $\mathbf{P} 80 \%$ & 13,19 & $\mathbf{P} 80 \%$ & 14,61 \\
\hline & P95\% & 40,81 & P95\% & 55,56 & P95\% & 59,63 & P95\% & 43,34 & P95\% & 39,74 & P95\% & 47,82 \\
\hline
\end{tabular}

Risco associado a diferença de preço entre os submercados Sudeste e Norte ( $R \$ / M W h$ )

\begin{tabular}{|c|c|c|c|c|c|c|c|c|c|c|c|c|}
\hline \multirow[t]{2}{*}{ Compra/ Venda } & \multicolumn{2}{|c|}{2015} & \multicolumn{2}{|c|}{2016} & \multicolumn{2}{|c|}{2017} & \multicolumn{2}{|c|}{2018} & \multicolumn{2}{|c|}{2019} & \multicolumn{2}{|c|}{$2015-2019$} \\
\hline & Esperado & 55,84 & Esperado & 25,74 & Esperado & 22,38 & Esperado & 11,63 & Esperado & 11,74 & Esperado & 25,46 \\
\hline \multirow{4}{*}{ Sudeste/ Norte } & P5\% & 5,41 & P5\% & 0,00 & P5\% & 0,00 & P5\% & 0,00 & P5\% & 0,00 & P5\% & 1,08 \\
\hline & $\mathbf{P} 20 \%$ & 21,66 & $\mathbf{P} 20 \%$ & 0,65 & P20\% & 0,90 & $\mathbf{P} 20 \%$ & 0,00 & P20\% & 0,00 & $\mathbf{P} 20 \%$ & 4,64 \\
\hline & $\mathbf{P 8 0} \%$ & 81,50 & $\mathbf{P} 80 \%$ & 46,09 & $\mathbf{P} 80 \%$ & 37,88 & $\mathbf{P} 80 \%$ & 19,52 & $\mathbf{P} 80 \%$ & 21,90 & $\mathbf{P} 80 \%$ & 41,38 \\
\hline & $\mathbf{P 9 5 \%}$ & 108,19 & P95\% & 117,97 & P95\% & 91,75 & $\mathbf{P 9 5 \%}$ & 57,38 & P95\% & 51,02 & $\mathbf{P 9 5 \%}$ & 85,26 \\
\hline
\end{tabular}




\subsection{Risco associado à Sazonalização dos contratos}

Em razão do perfil de consumo do cliente sofrer variações ao longo do ano (sazonais), ele pode optar em aplicar esse perfil no contrato anual de energia.

Modelagem:

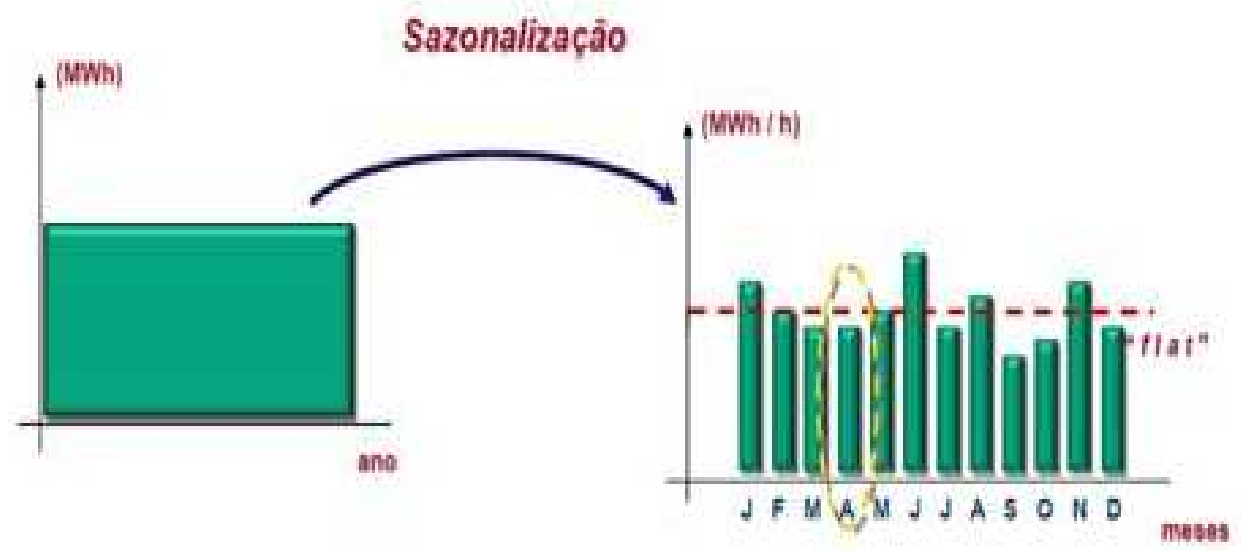

Figura 43 - Saz̧onalização (Fonte: Confecção própria)

A sazonalidade é modelada como uma variação uniforme de um percentual definido do volume mensal contratado, de forma que a soma dos volumes mensais sazonalizados é equivalente ao volume anual contratado.

O resultado considera o intervalo de confiança de $95 \%$ e mede o risco de perda financeira em função de cenários desfavoráveis de exercício de sazonalidade e a valoração deste risco considera diferenças de preços do contrato e preços no mercado de curto prazo.

A mensuração dos desvios entre o portfólio com seus vários contratos com requisitos de sazonalidade e a carteira cujos contratos são "flat" resulta nas precificações dispostas abaixo, de acordo com o percentual de variação concedido.

Tabela 13 - Risco associado à sazonalização precificado considerando o P5\% (R\$/MWh)

\begin{tabular}{cc}
\multicolumn{2}{c}{ Sazonalidade - R \$ $/ \mathbf{M W h}$} \\
\hline$\%$ de Sazo & $2015-2019$ \\
\hline $5 \%$ & $-1,22$ \\
$10 \%$ & $-2,87$ \\
$15 \%$ & $-3,69$ \\
$20 \%$ & $-5,24$ \\
\hline
\end{tabular}


Tal risco pode ser mitigado se a sazonalização da garantia física da usina hidrelétrica que lastreia parte dos contratos de venda acompanhar o perfil de sazonalidade dos contratos de venda. No entanto, deve-se definir a melhor estratégia de sazonalização da Garantia Física dessa usina de acordo com a possibilidade de ganhos ou mitigação de risco de exposição em função de cenários de secundária e rebaixamento do MRE e da perspectiva de evolução de preços no mercado de curto prazo. 


\section{MODELO DE NEGÓCIO}

Conforme discutido anteriormente, a produção de energia das plantas de cogeração a biomassa ocorre apenas durante a colheita da cana, que coincide com a época seca do sistema hidrelétrico. De maneira análoga, os valores de geração eólica ficam acima da média em boa parte do período seco das hidrelétricas. E apesar das hidrelétricas enfrentarem o risco hidrológico em períodos de seca, podem compensar a indisponibilidade de cogeração a biomassa e a menor produção das eólicas durante o resto do ano.

A complementação energética entre diferentes tipos de fontes geradoras de eletricidade pode, no contexto das novas regras de mercado de venda de energia e a depender de alguns fatores, se constituir em um mecanismo de hedge financeiro para as empresas geradoras de energia. $\mathrm{O}$ quanto um gerador pode se beneficiar da decisão de realizar investimentos, em uma carteira de projetos composta por diferentes fontes geradoras, depende de vários fatores:

i. Da sinergia entre as fontes, ou seja, do grau de correlação que possa existir entre a produção energética sazonal das fontes;

ii. Da potência a ser instalada de cada fonte;

iii. Do quanto o despacho dessa fonte vai impactar o preço de liquidação de diferenças (PLD), que tem como "proxy" o custo marginal de operação e vice versa, o quanto o comportamento do PLD vai afetar o acionamento econômico da planta em tela;

iv. Da amplitude das flutuações no PLD em torno do valor médio de longo termo, função das hidrologias consideradas;

v. Do custo variável da fonte geradora e restrições de operação da fonte (Fatores de capacidade máximo e mínimo).

Neste contexto, a premissa de estruturação do modelo de negócio é a de que uma empresa detentora de ativos de geração hidrelétrica compra os direitos de produção de uma eólica e/ou de uma biomassa (contrato por capacidade) para incorporar em seu portfólio e vender em forma de contrato "por quantidade" em energia firme. A questão para a empresa é determinar a quantidade de energia a ser comprada de cada fonte, o preço de compra para que seja possível revendê-la a um preço definido através de um contrato por quantidade com consumidor livre que visa atender a sua demanda. 
Deve ser analisada ainda a estratégia mais indicada de contratação da produção garantida do empreendimento conjunto, quantificando-se as receitas que podem ser auferidas para cada nível de contratação e perfil de contrato em análise, de forma a maximizar os ganhos de comercialização sob condicionamento de critérios de risco pré-fixados.

Uma variação do modelo de negócio anterior foi definida de forma a utilizar a garantia física da empresa detentora de ativos de geração hidrelétrica para complementação da disponibilidade do portfólio de energia eólica e/ou biomassa, adquirido da compra de contratos de capacidade, sem a mistura da energia, apenas para hedge financeiro da exposição ao mercado spot. A estratégia prevê deslocamento de parte da garantia física existente do empreendedor, equivalente ao montante de exposição da usina eólica e/ou biomassa, de maneira que as exposições ao PLD sejam canceladas financeiramente. No entanto, tal estratégia de sazonalização da Garantia Física do portfólio de energia hidrelétrica convencional impacta a alocação de energia do mecanismo de realocação de energia - MRE e, por conseguinte, eventuais ganhos com secundária ou perdas com rebaixamento. Este condicionante foi, portanto, mensurado.

Ao adquirir a "curva de geração" da eólica e/ou biomassa, incorporando a sua Garantia Física existente e negociando a venda do total de lastro disponível, o gerador assume todos os riscos de mercado na comercialização e, por consequência, mitiga completamente os riscos de mercado do empreendedor da eólica e/ou cogeração. Neste caso, a decisão de sazonalização da Garantia Física de um gerador proprietário de uma usina hidrelétrica pode mudar consideravelmente com a incorporação de uma usina de biomassa e/ou eólica em seu portfólio.

Deste modo, o objetivo do trabalho passa a ser norteado pela busca de arranjos negociais e regulatórios que permitam maximizar os ganhos econômicos para os parceiros do Projeto, internalizando os ganhos de sinergia identificados na etapa anterior do trabalho, com um nível de risco de exposição ao mercado "spot" que possa ser assimilado de forma confortável pelos acionistas controladores.

Nesse âmbito de premissas, em que a empresa literalmente "compra a curva de geração" da planta eólica e/ou biomassa, mitigando totalmente o risco de comercialização do empreendedor destas fontes, o preço de compra pago não deve incluir prêmio de risco e pode ser mais baixo já que todo o risco de Mercado está alocado na empresa que adquire a energia incentivada por contratos de disponibilidade. 
No entanto, caso a planta eólica e/ou biomassa sozinha não atinja a exigência de risco, o diferencial de preço entre compra e venda de sua geração tem função de alavancar a eólica e/ou biomassa ao nível de risco fixado. Com montantes mais reduzidos de compra de energia destas fontes, a sinergia é suficiente para por si só gerar essa alavancagem e se poderia pagar um preço de compra superior ao preço de venda.

\subsection{Configurações iniciais e premissas}

A formulação estocástica do problema requer um conjunto de cenários de preços spot (PLD), geração eólica e alocação de energia do Mecanismo de Realocação de Energia do qual faz parte a usina hidrelétrica, para permitir modelar as incertezas presentes no problema. Dessa forma, uma amostra de 63 cenários de preços mensais e energia alocada do MRE (baseados nos valores históricos de vazões) foram obtidas para um horizonte temporal de 5 anos. Ademais os cenários de geração eólica resultam do histórico reconstituído de 63 anos de um macro-sítio do Estado do Ceará, cuja energia mensal disponível é o resultado da multiplicação da Garantia Física pelo fator eólico, em cada mês e cenário do histórico. O comprimento da série histórica considerada (63 anos) decorre da reconstituição de anos de velocidades de vento a partir de modelos de mesoescala, tendo-se utilizado dados do NOAA - National Oceanic and Atmospheric Administration, que se iniciam em 1948.

A oportunidade de negócio leva em consideração a sazonalidade por meio da composição mensal da receita total. As usinas eólicas e as movidas a biomassa foram representadas na modelagem como não despacháveis pelo Operador Independente do Sistema, enquanto a hidrelétrica foi analisada como pertencente ao Mecanismo de Realocação de Energia, ou seja com despacho centralizado e com alocação de energia proporcional à geração de todas as hidrelétricas do mecanismo.

É válido mencionar que a partir de janeiro de 2015 entraram em vigor os novos valores máximo e mínimo de preço da energia no mercado de curto prazo (PLD). O teto passou de R\$ 822,83/MWh para R \$ 388,48 MWh. Já o preço mínimo foi elevado de R\$15,62 MWh para R\$ 30,26 MWh. Para a mudança no cálculo do PLD, a ANEEL usou o conceito de térmica relevante e definiu que, atualmente, essa usina seria a de Mário Lago, que tem custo de geração de energia de $\mathrm{R} \$ 388,48$ MWh e combustível a gás. 


\section{Etapas:}

1) Elaboração do cenário de oferta e demanda para um horizonte que contemple o período do estudo (2015-2019);

2) Simulação dos despachos hidrotérmicos, considerando os procedimentos de aversão a risco vigentes ao longo do horizonte do cenário de oferta e demanda, e eólico estocásticos para o cálculo de cenários de PLD e de geração física das usinas;

3) Simulação do Mecanismo de Realocação de Energia (MRE) para o cálculo dos cenários de energia alocada à usina hidrelétrica;

4) Representação do portfólio físico e comercial (garantia física das usinas e volumes/preços de contratos);Determinação do total de energia do portfólio disponível no mês, para cobertura do contrato de venda;

5) Alocação de parcela de garantia física ao contrato de venda flat;

6) Apuração da Receita Fixa advinda do montante de garantia física alocada ao contrato de venda flat, ao preço do contrato;

7) Apuração das diferenças entre a energia disponível e o total de energia comprometida com o contrato de venda (processo também chamado de contabilização), em cada mês do período de estudo;

8) Liquidação ou valoração das diferenças mensais apuradas na contabilização ao valor do respectivo PLD, para apuração do Custo Spot;

9) Apuração da Receita Ĺ́quida Mensal $^{22}$ através da soma do resultado do Custo Spot (liquidação a PLD) com a Receita Fixa (contrato de venda), em cada mês do horizonte analisado, para cada série (não se trata da receita líquida de fato, pois não se levou em conta o custo de aquisição das curvas de geração das fontes eólica e a biomassa. O preço para adquiri-las foi calculado a parte);

10) Consolidação das receitas líquida mensais em receitas anuais esperadas para cada um dos cinco anos do horizonte e para cada um dos cenários estocásticos;

11) Cálculo do VaR e do CVaR sobre a amostra de resultados das receitas anuais esperadas;

12) Cálculo da Receita Total média anual no horizonte de estudo através do somatório das Receitas Líquidas Mensais apuradas em cada cenário.

13) Cálculo do indicador de risco x retorno do portfólio atual.

14) Otimização do portfólio de contratos, de acordo com um critério de risco x retorno.

22 Receitas/despesas no MRE e excedentes financeiros também compõem a receita de um agente gerador hidrelétrico. Para fins de simplificação, esses valores não foram computados. 


\section{Fluxograma do modelo de otimização}

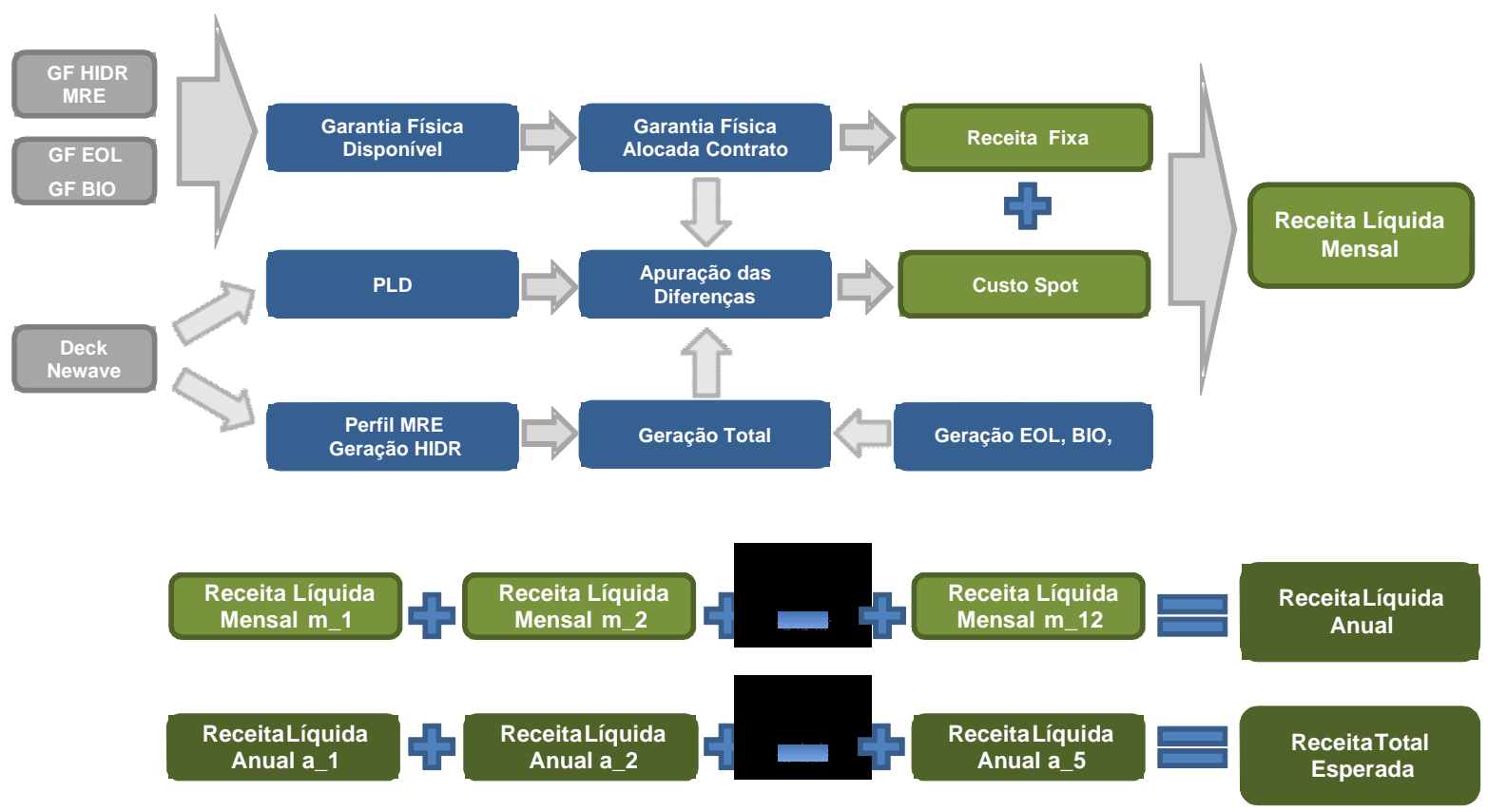

O modelo deve ser capaz de representar, com certo grau de similaridade ao mundo real, a sinergia existente entre as fontes estudadas, com foco na maximização da receita no horizonte de estudo, para um determinado portfólio, dado um nível de aceitação de risco definido pelo VaR e CVaR.

\subsection{Simulação Cenário Base}

Nas condições atuais do sistema interligado, com níveis de armazenamento no início do ano de 2015 na ordem de 20\% da capacidade máxima e afluências muito abaixo da média histórica, que definem uma situação de suprimento energético nada confortável (escassez), supõe-se que um gerador seja capaz de assinar contratos de venda "por quantidade" com consumidores livres com preço fixado em $\mathrm{R} \$ 180,00 / \mathrm{MWh}$ no período $2015-2019^{23}$. O preço considerado é superior ao valor médio dos cenários de PLD no período analisado (R \$165/MWh).

Nas tabelas 14 e 17 estão as características das fontes de geração que poderão compor o portfólio do gerador. Neste caso, definiram-se portfólios de acordo com a representatividade de usinas eólicas e biomassa.

\footnotetext{
23 A precificação de contratos e uma expectativa de tipos de contrato (prazo de início da entrega e duração) em função da liquidez do mercado podem ser definidos com suporte de metodologia específica, tema de Tese de Doutorado em fase de conclusão, a ser apresentada em trabalho futuro.
} 
A composição da carteira segundo risco mínimo foi definida conforme discorrido no tópico 8.3.2, aplicado às condições sistêmicas e preço de contrato agora considerados. Arbitrou-se a potência total das fontes eólica e de cogeração a biomassa como equivalente a 50\% da capacidade da hidrelétrica para compor a carteira de participação expressiva das fontes alternativas.

Os cenários de receita demonstrados traduzem o montante médio anual do período de análise.

As tabelas 15 e 18 trazem o resumo dos resultados. Menores desvios entre VaR e CVaR em relação à Receita Ótima expressam menores riscos ao empreendedor ao apostar na configuração de portfólio analisada e vice-versa.

As tabelas 16 e 19 referem-se aos desvios da Receita ótima em relação à Receita de Referência e desvios da Receita Mínima (P5\%) e CVaR em relação aos limites de risco aceitáveis equivalentes a 85\% e 80\% da Receita de Referência, respectivamente. É possível visualizar então quando uma carteira proposta atingiu os limites de risco definidos, sempre que os valores de desvios da Receita mínima e CVaR estão acima de 100\%. Valores abaixo de 100\% expressam inviabilidade. Uma vez que as medidas de Receita de Referência, Receita Mínima, VaR e CVaR variam em cada etapa da simulação, de acordo com a composição, volume (Garantia Física) das fontes de uma carteira, bem como preço adotado, torna-se necessário trabalhar com valores relativos em percentual de Receita de Referência e VaR e CVaR limite, a fim de comparar as opções expostas em uma mesma base.

O preço a ser pago para adquirir a geração das fontes alternativas (eólica e cogeração a biomassa) pode ser obtido pelo ganho em risco (CVaR) do portfólio após a inserção destas fontes em relação ao portfólio inicial puramente hidrelétrico. Calcula-se então a diferença entre os valores absolutos de CVaR em R \$ sobre a energia adquirida em MWh.

Para fins de apuração da complementaridade dos perfis de geração das fontes em análise, trabalhou-se, no cenário base, sem alterações na estratégia de sazonalização da garantia física da usina hidrelétrica, assim sendo, sua sazonalização foi considerada constante ('flat') para todo período, o que tem o mesmo efeito de seguir a média da sazonalização das usinas do MRE. Posteriormente, adotou-se nova estratégia de sazonalização com perfil contrário à geração média das fontes eólica e a biomassa. 
As análises iniciais consideraram contratos de venda "flat", ou seja, com volumes constantes em toda a análise. Ao final simulou-se o portfólio com uma variedade de contratos de venda de energia com atributos de sazonalidade e flexibilidade.

Tabela 14 - Composição do Portfólio com participação expressiva de energia eólica e biomassa

\begin{tabular}{lccc} 
& Hidrelétrica & Eólica & Biomassa \\
\cline { 2 - 4 } Total Potência - MW & 1820,0 & 450,0 & 450,0 \\
Total Garantia Física - MWm & 1000,0 & 223,9 & 236,3 \\
\hline
\end{tabular}

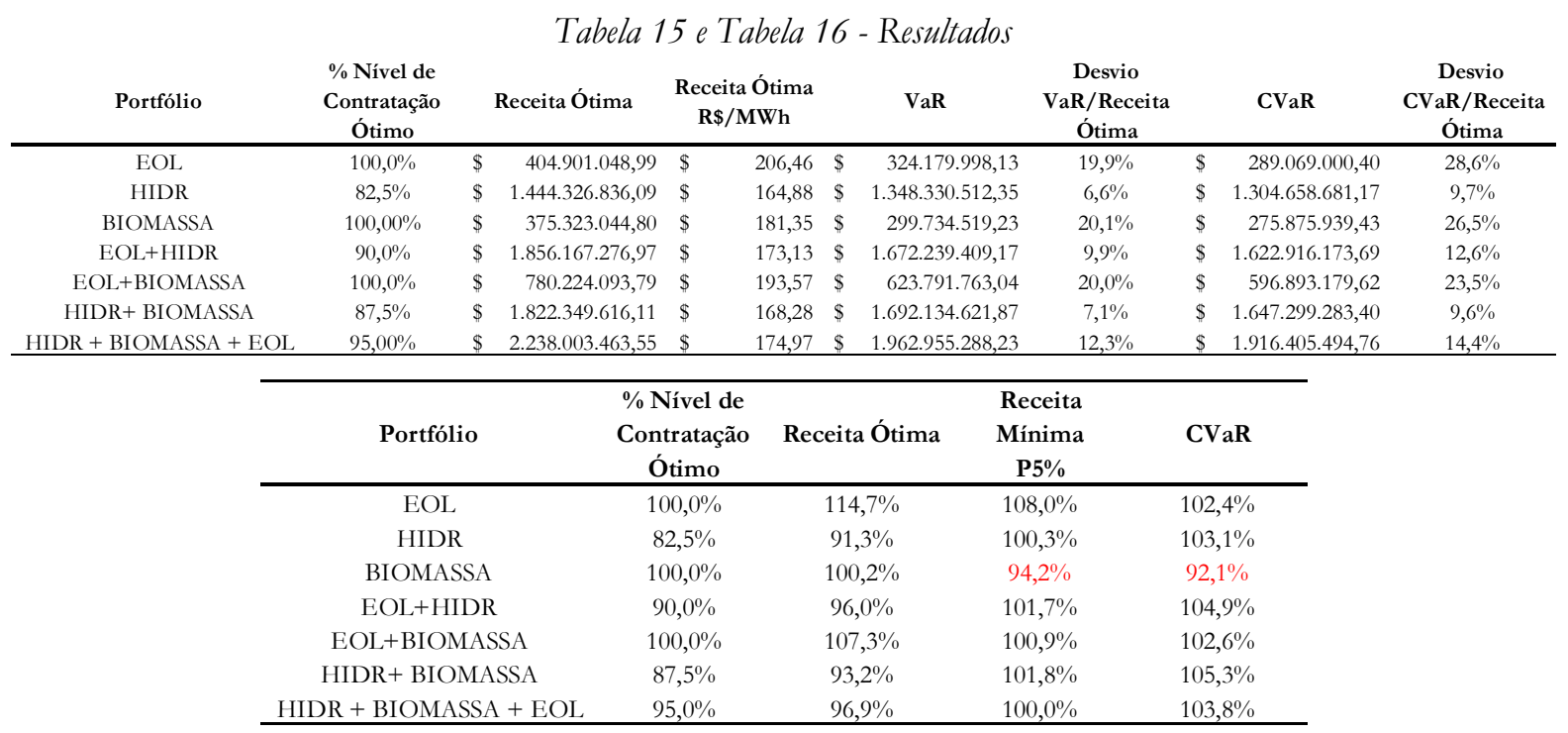

Receita Anual e Risco x Contratação

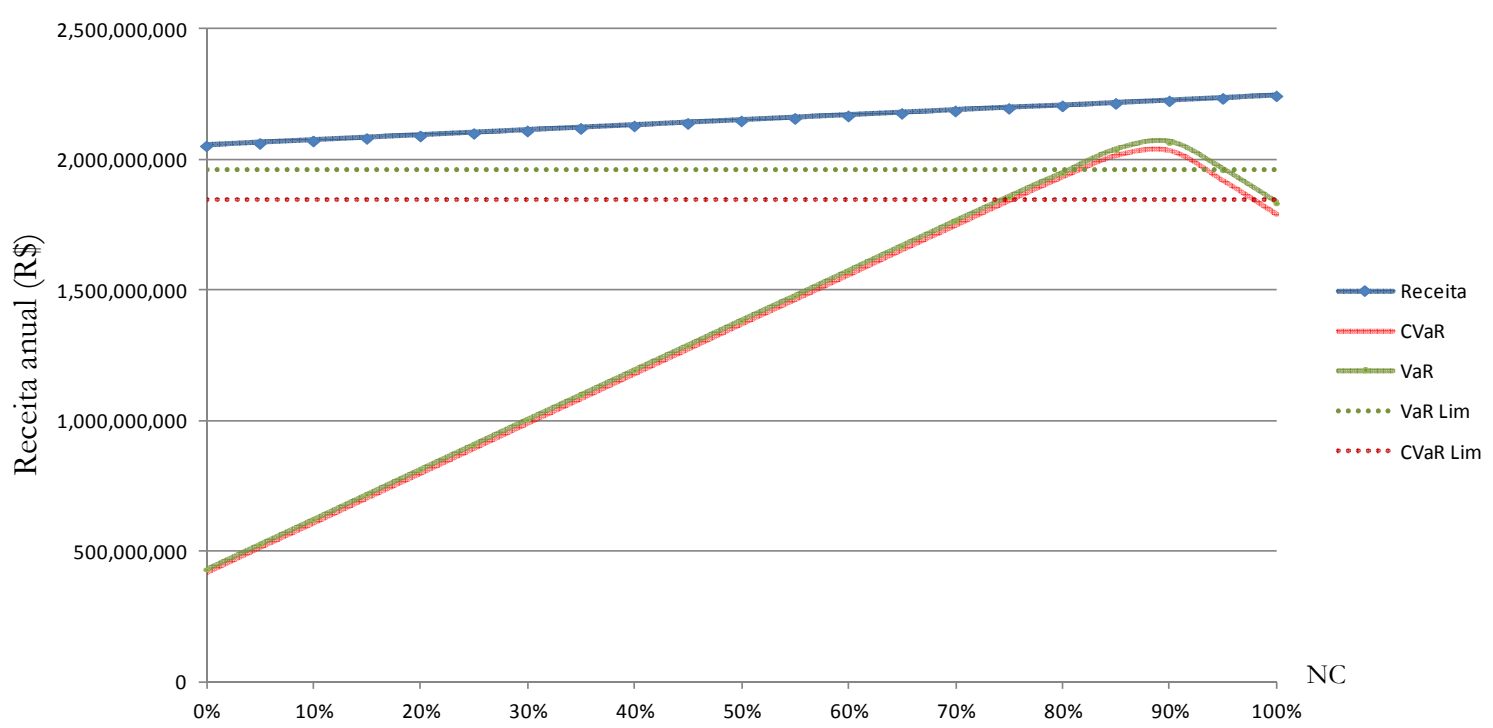

Figura 44 - Receita anual e Parâmetros de Risco (R\$) × NC (\%) do porffólio com participação expressiva de energia eólica e biomassa em condição de escassez e preço de venda de R\$180/MWh (Fonte: Confecção própria) 
Tabela 17 - Composição do Portfólio com menor participação de energia eólica e biomassa (Risco mínimo)

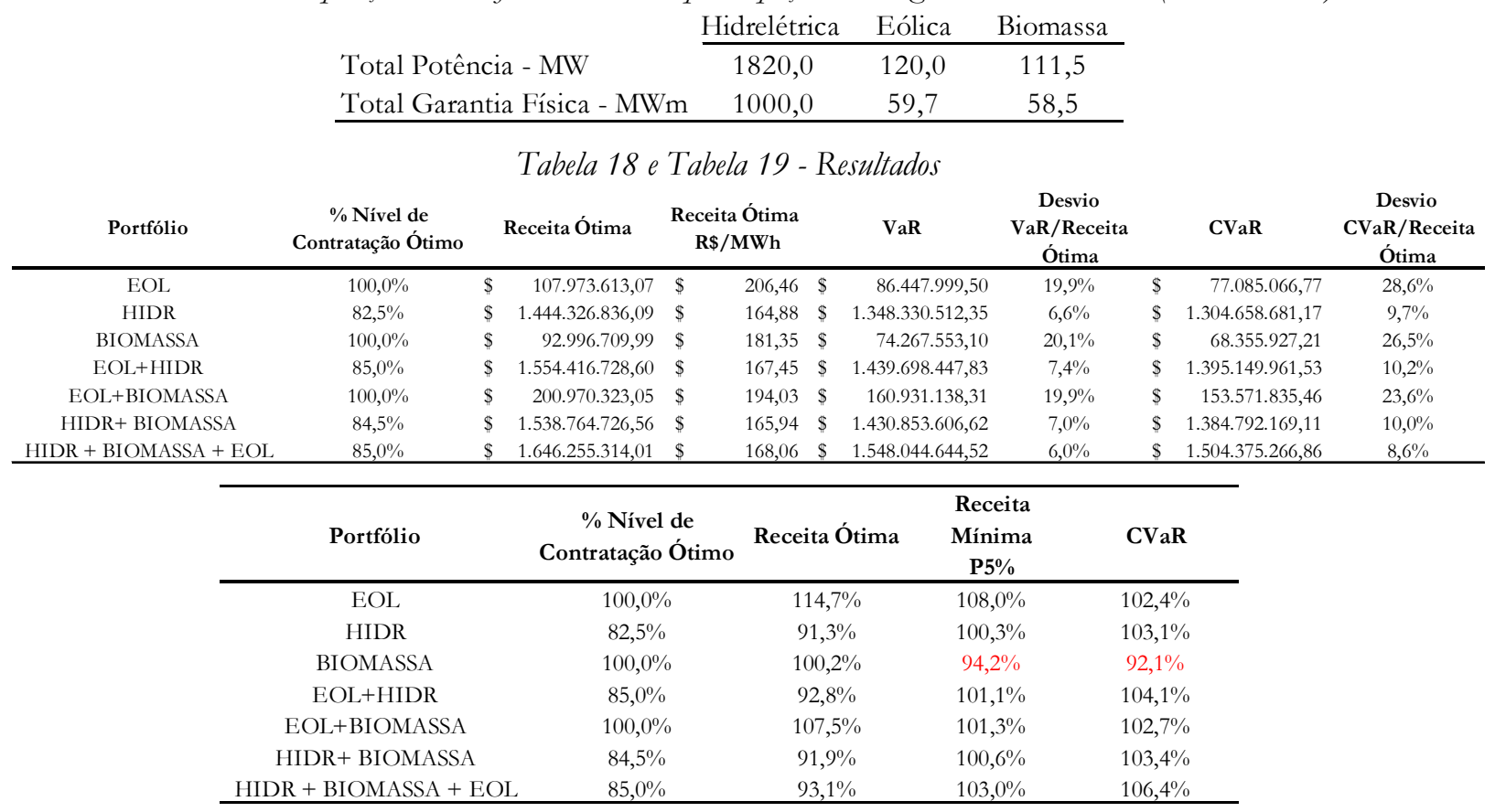

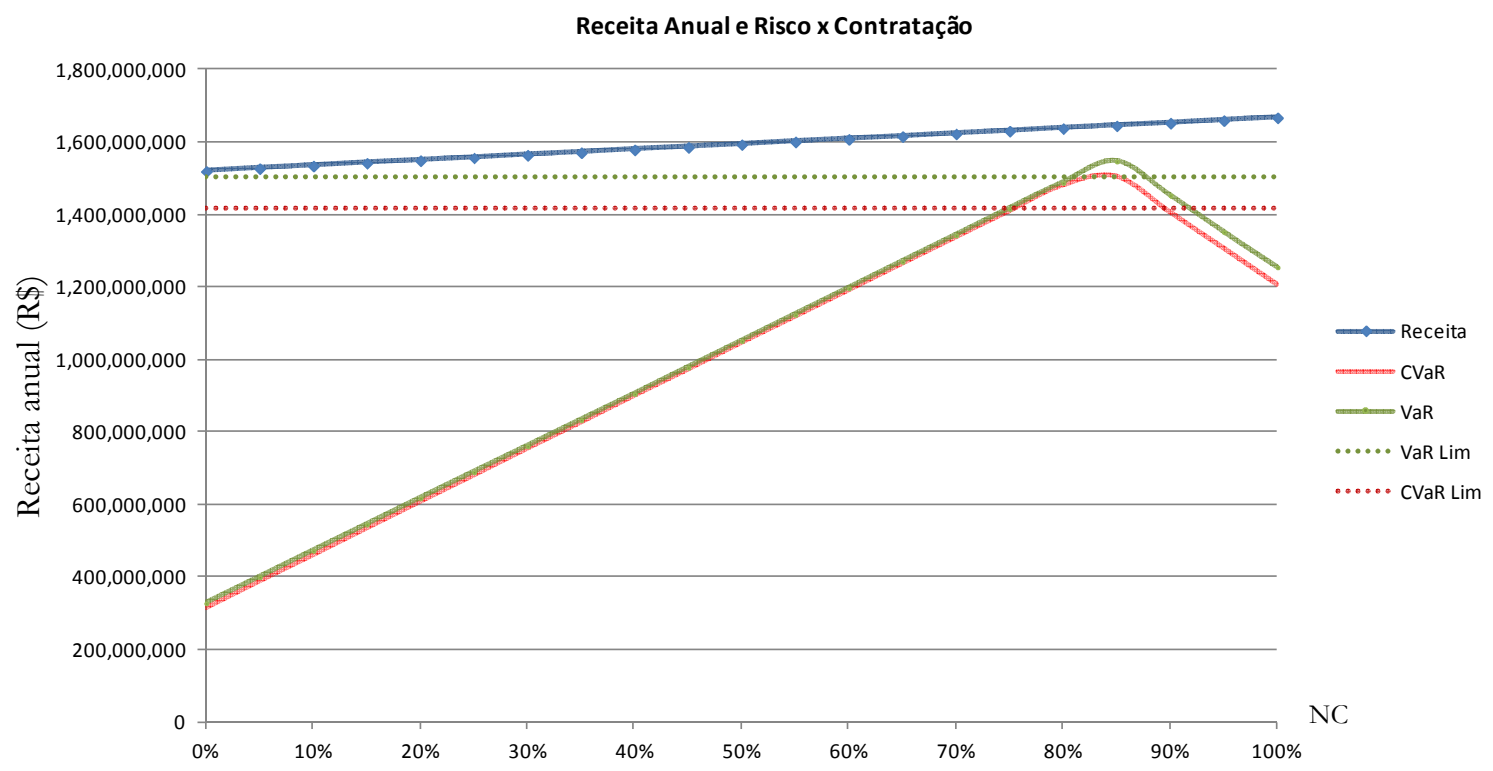

Figura 45 - Receita anual e Parâmetros de Risco $(\mathrm{R} \$) \times N C(\%)$ do portfólio com menor participação de energia eólica e biomassa em condição de escassez. e preço de venda de R\$180/MWh (Fonte: Confecção própria)

Por meio dos gráficos acima, resultantes da simulação do portfólio combinado das três fontes, é possível analisar a evolução da receita esperada (linha azul contínua), do VaR (linha verde contínua) e CVaR (linha vermelha contínua) em função do percentual de garantia física disponibilizado à contratação. A linha pontilhada vermelha indica o CVaR limite $(80 \%$ da Receita de Referência) e a linha pontilhada verde indica o VaR (85\% da Receita de Referência). Em termos visuais, o gráfico indica a solução otimizada para o maior valor de receita esperada 
quando as linhas contínuas verde $(\mathrm{VaR})$ e vermelha (CVaR) estiverem acima das linhas pontilhadas horizontais verde $\left(\mathrm{VaR}_{\text {limite }}\right)$ e vermelha $\left(\mathrm{CVaR}_{\text {limite) }}\right.$, respectivamente, o que significa encontrar o maior valor de receita para valores de VaR e CVaR que atendam os limites impostos.

A identificação do hedge é dada pelo ganho do CVAR do portfólio combinado em relação aos resultados individuais somados. Quanto maior o CVAR, mais próximos da receita média estarão os valores esperados de receita da simulação, minimizando os riscos de perda de receita.

Os portfólios que resultaram em maior retorno são aqueles compostos pelas plantas eólica e biomassa individualmente ou a combinação das duas fontes. No entanto, o risco incorrido é nitidamente maior, haja vista o grande desvio entre a média dos piores cenários de receita - CVaR e a receita esperada para estes portfólios, o que representa a perda de receita que o gerador está sujeito em decorrência da intermitência da geração destas fontes e a não existência de um mecanismo de hedge como o MRE, que se aplica apenas para as hidrelétricas.

A usina a biomassa sozinha não atende as restrições de risco impostas. Além disto, como o gerador já é detentor da usina hidrelétrica, as opções de portfólio são as que incluem tal fonte, ou seja, carteiras apenas de usinas eólicas ou a biomassa estariam descartadas.

É evidente o "hedge" que as fontes têm entre si e os benefícios que o investidor encontra quando explora a sinergia entre estas fontes. Em termos de risco, a combinação das fontes implica em um ganho no CVaR de 46,8 milhões de reais/ano na carteira com maior participação das fontes alternativas e de 54,3 milhões de reais/ano na carteira de risco mínimo, quando se compara com a soma do CVaR de cada fonte individualmente, já considerando o nível de contratação ótimo.

À medida que se aumenta a participação das fontes eólica e a biomassa no portfólio pode-se alavancar o \% de contratação, mas em contrapartida há o acréscimo no risco.

Com montantes mais reduzidos de compra das plantas eólica e biomassa, resultado da análise da carteira de risco mínimo, a sinergia é suficiente para alavancar a carteira, ao nível de risco fixado, permitindo pagar um preço de até R \$ 192,80/MWh pela aquisição da curva de geração de tais fontes, superior ao preço de venda de $\mathrm{R} \$ 180,00 / \mathrm{MWh}$. Com montantes mais significativos, não se atinge a exigência de risco e o diferencial de preço entre compra e venda de sua geração tem função de alavancar tais fontes ao nível de risco fixado. Neste caso, pode-se pagar o valor de até $\mathrm{R} \$ 151,80 / \mathrm{MWh}$ atrelado ao valor de venda de R\$180,00/MWh. 


\section{Análise dos fatores de risco:}

Tabela 20 - Média e Desvio-Padrão (Volatilidade) das variáveis de ris
\begin{tabular}{lrr} 
Fonte & Média Anual & Desvio-Padrão \\
\hline HIDR (MWm) & 983,3 & 101,0 \\
EOL (MWm) & 69,7 & 35,2 \\
BIO (MWm) & 58,5 & 49,5 \\
PLD (R\$/MWh & 163,64 & 135,84 \\
\hline
\end{tabular}

Por meio da análise da média e desvio-padrão das variáveis que compõem e influenciam o resultado da comercialização de um agente, é possível observar aquelas que introduzem maior incerteza nos resultados do negócio.

É inquestionável a variabilidade e imprevisibilidade do preço no mercado de curto prazo, o qual valora os montantes de exposição no processo de liquidação das diferenças. É um dos fatores preponderantes nas decisões de risco. Tão relevante quanto o PLD, pode-se citar a variabilidade da cogeração a biomassa ao longo do ano, caracterizando o motivo da inviabilização da carteira desta fonte individualmente.

O risco significativo da fonte eólica, observado pelo desvio entre o CVaR e a receita esperada (Tabelas 15 e 18), é notado também no desvio-padrão da fonte. Já a geração hidrelétrica foi a variável com menor volatilidade, o que é justificado pela alocação mais constante de energia do MRE ainda que sujeita à sazonalidade do recurso hídrico. Convém lembrar que o grande risco enfrentado pelas hídricas é a elevada correlação negativa de sua geração com o PLD.

\section{Análise da complementaridade:}

Para aferir a complementaridade das variáveis energéticas consideradas (Energia Natural Afluente - ENA, geração eólica e de cogeração a biomassa) analisou-se a correlação ${ }^{24}$ de seus comportamentos. Utilizou-se a ENA ou invés de geração hidrelétrica, uma vez que a segunda é influenciada por decisões de despacho do operador. O resultado demonstrou uma significativa correlação negativa entre as variáveis ENA e geração eólica (cerca de -0,63), e ENA e geração a biomassa (cerca de 0,74). Já as variáveis de geração eólica e cogeração a biomassa apresentaram

\footnotetext{
${ }^{24}$ No uso estatístico geral, correlação se refere a medida da relação entre duas variáveis, embora correlação não implique causalidade.
} 
uma correspondência positiva equivalente a 0,64 considerando as séries estocásticas e período contemplado no estudo.

\subsection{Sensibilidade de Garantia Física da Fonte Eólica}

Uma vez que a garantia física da usina eólica foi calculada segundo o critério do $\mathrm{P} 90 \%$ dos dados históricos reconstituídos que deram origem às séries de geração, a análise em questão consiste em se utilizar o P50\% para se obter um novo valor de placa à usina. Isto significa que somente em $50 \%$ das ocorrências, a geração estará acima do valor da garantia física. Somente para esta sensibilidade os novos volumes considerados são:

Tabela 21 - Composição do Portfólio com participação expressiva de energia eólica (GF critério P50\%) e biomassa

\begin{tabular}{lccc} 
& Hidrelétrica & Eólica & Biomassa \\
\cline { 2 - 4 } Total Potência - MW & 1820 & 450 & 450 \\
Total Garantia Física - MWm 1000,0 & 253,8 & 236,3 \\
\hline
\end{tabular}

Tabela 22 - Composição do Portfólio com menor participação de energia eólica (GF critério P50\%) e biomassa (Risco mínimo)

\begin{tabular}{lccc} 
& Hidrelétrica & Eólica & Biomassa \\
\cline { 2 - 4 } Total Potência - MW & 1820 & 120 & 111,5 \\
Total Garantia Física - MWm1000,0 & 67,7 & 58,5 \\
\hline
\end{tabular}

Tabela 23 e Tabela 24 - Resultados do Portfólio com participação expressiva de energia eólica (GF critério P50\%) e biomassa em condição de escassez. e preço de venda de $\mathrm{R} \$ 180 / \mathrm{MWh}$

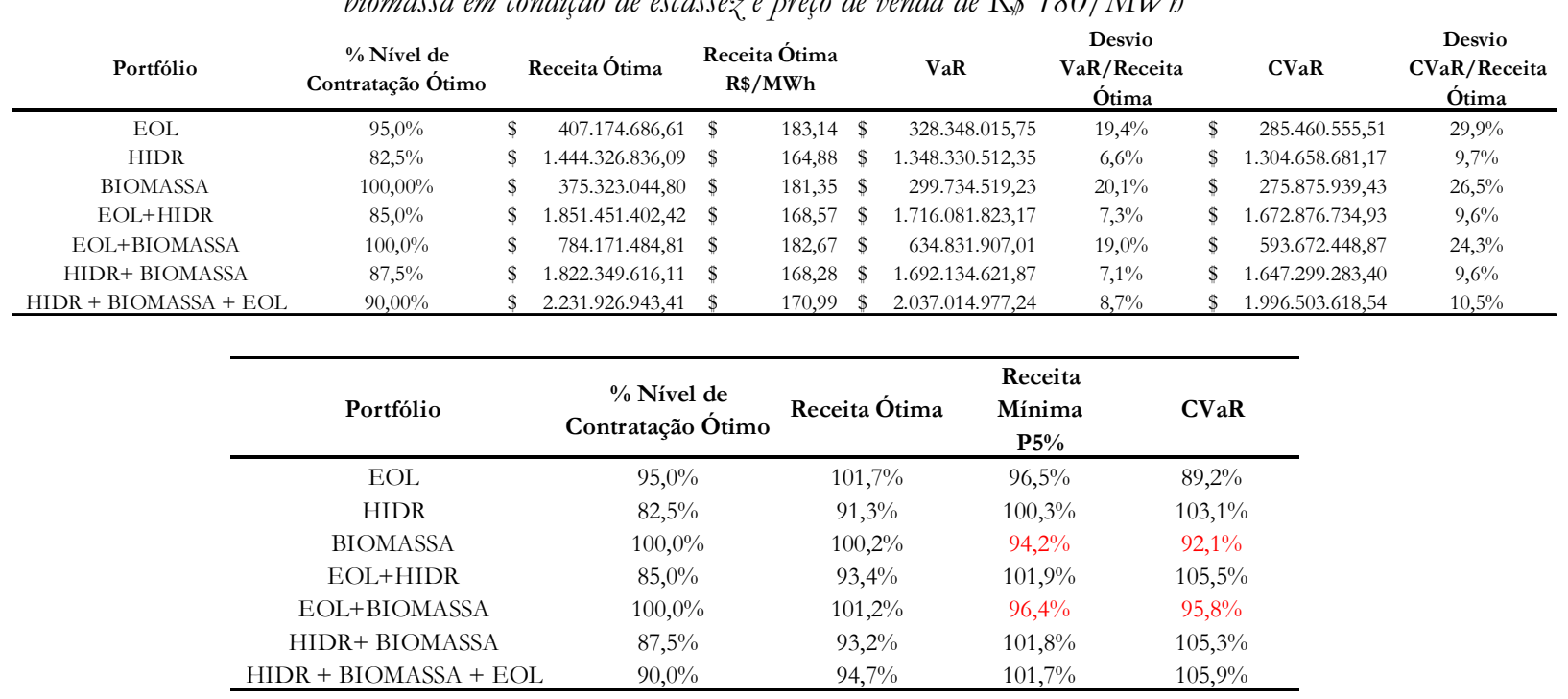




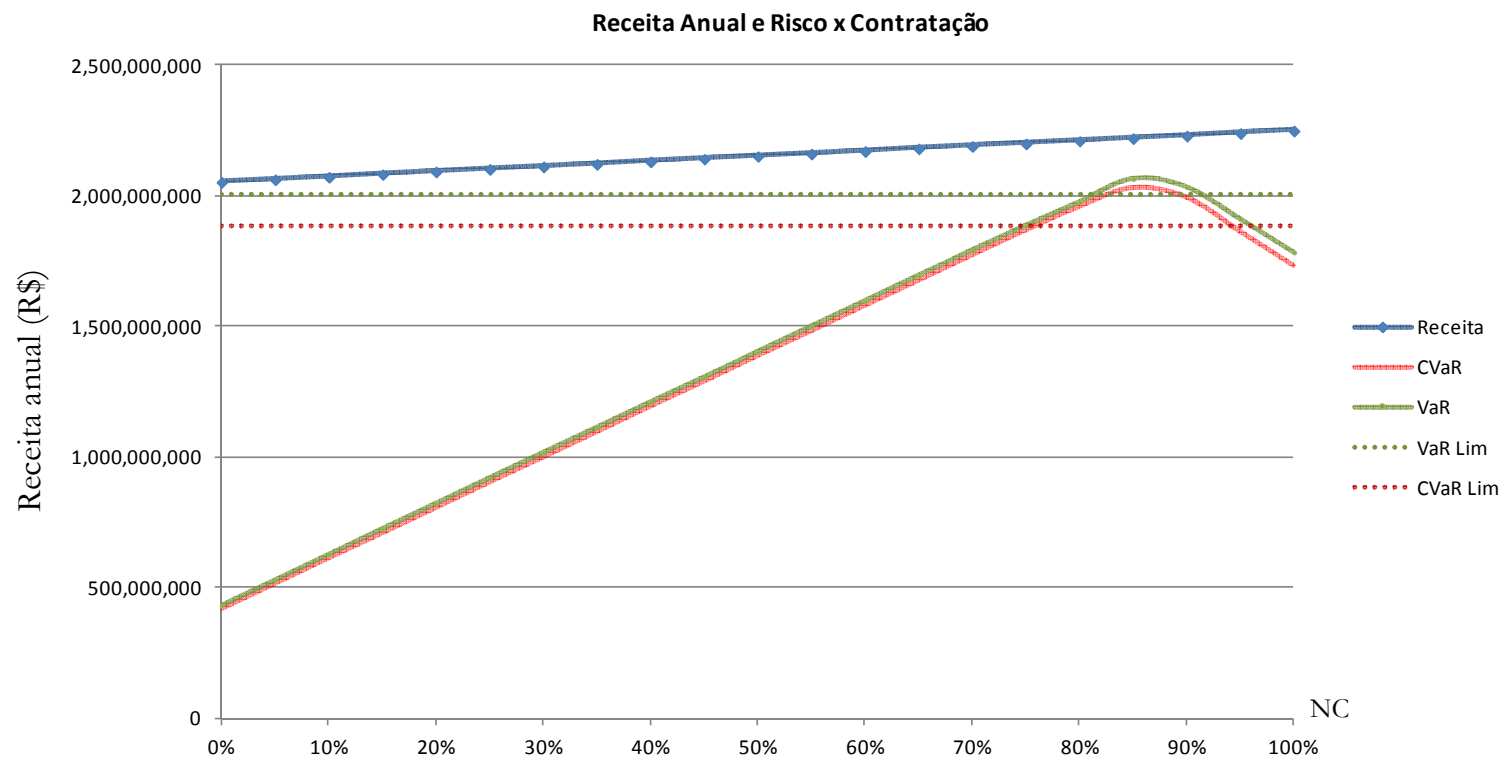

Figura 46 - Receita anual e Parâmetros de Risco (R\$) × NC (\%) do portfólio com participação expressiva de energia eólica (GF no critério P50\%) e biomassa em condição de escassez e preço de venda de R\$180/MWh (Fonte: Confecção própria)

Tabela 25 e Tabela 26 - Resultados do Porfólio com menor participação de energia eólica (GF critério P50\%) e biomassa (Risco minimo) em condição de escassez e preço de venda de $\mathrm{R} \$ 180 / \mathrm{MWh}$

\begin{tabular}{|c|c|c|c|c|c|c|c|c|c|c|}
\hline Portfólio & \multicolumn{2}{|l|}{$\begin{array}{c}\% \text { Nível de } \\
\text { Contratação Ótimo }\end{array}$} & Receita Ótima & \multicolumn{2}{|c|}{$\begin{array}{c}\text { Receita Ótima } \\
\text { R\$/MWh }\end{array}$} & \multicolumn{2}{|c|}{ VaR } & \multicolumn{2}{|c|}{$\begin{array}{c}\text { Desvio } \\
\text { VaR/Receita } \\
\text { Ótima } \\
\end{array}$} & \multirow{2}{*}{$\begin{array}{c}\mathrm{CVaH} \\
76.12\end{array}$} \\
\hline EOL & $95,0 \%$ & $\$$ & $108.579 .916,43$ & $\$$ & 183,14 & 87.5 & 470,87 & $19,4 \%$ & $\$$ & \\
\hline HIDR & $82,5 \%$ & $\$ 1$ & 1.444.326.836,09 & $\$$ & 164,88 & $\$ 1.348 .3$ & 512,35 & $6,6 \%$ & $\$$ & 1.304 .6 \\
\hline BIOMASSA & $100,00 \%$ & $\$$ & $92.996 .709,99$ & $\$$ & 181,35 & 74.2 & 553,10 & $20,1 \%$ & $\$$ & \\
\hline $\mathrm{EOL}+\mathrm{HIDR}$ & $82,5 \%$ & $\$ 1$ & $1.551 .790 .916,91$ & $\$$ & 165,92 & $\$ \quad 1.445 .8$ & 164,12 & $6,8 \%$ & $\$$ & 1.417 .0 \\
\hline EOL+BIOMASSA & $100,0 \%$ & $\$$ & 202.022.960,66 & $\$$ & 182,72 & 163.5 & 298,81 & $19,0 \%$ & $\$$ & 152 \\
\hline \multirow{2}{*}{$\begin{array}{c}\text { HIDR+ BIOMASSA } \\
\text { HIDR + BIOMASSA + EOL }\end{array}$} & $84,5 \%$ & $\$ 1$ & $1.538 .764 .726,56$ & $\$$ & 165,94 & $\$ 1.430 .8$ & 606,62 & $7,0 \%$ & $\$$ & 1.384 .7 \\
\hline & $85,00 \%$ & $\$ \quad 1$ & 1.647.150.055,97 & $\$$ & 166,96 & $\$ \quad 1.539 .3$ & 498,86 & $6,5 \%$ & $\$$ & \\
\hline & \multicolumn{2}{|l|}{ Portfólio } & \multicolumn{2}{|c|}{$\begin{array}{c}\% \text { Nível de } \\
\text { Contratação Ótimo }\end{array}$} & \multicolumn{2}{|c|}{ Receita Ótima } & $\begin{array}{r}\text { Rec } \\
\text { Mín } \\
\text { P5 } \\
\end{array}$ & & \multicolumn{2}{|c|}{ CVaR } \\
\hline & \multicolumn{2}{|l|}{ EOL } & \multicolumn{2}{|l|}{$95,0 \%$} & \multicolumn{2}{|c|}{$101,7 \%$} & 96,5 & & \multicolumn{2}{|c|}{$89,2 \%$} \\
\hline & \multicolumn{2}{|l|}{ HIDR } & \multicolumn{2}{|l|}{$82,5 \%$} & \multicolumn{2}{|c|}{$91,3 \%$} & 100 , & & \multicolumn{2}{|c|}{$103,1 \%$} \\
\hline & \multicolumn{2}{|l|}{ BIOMASSA } & \multicolumn{2}{|c|}{$100,0 \%$} & \multicolumn{2}{|c|}{$100,2 \%$} & 94,2 & & \multicolumn{2}{|c|}{$92,1 \%$} \\
\hline & \multicolumn{2}{|l|}{$\mathrm{EOL}+\mathrm{HIDR}$} & \multicolumn{2}{|l|}{$82,5 \%$} & \multicolumn{2}{|r|}{$91,9 \%$} & 100 , & & \multicolumn{2}{|c|}{$104,9 \%$} \\
\hline & \multicolumn{2}{|l|}{ EOL+BIOMASSA } & \multicolumn{2}{|c|}{$100,0 \%$} & \multicolumn{2}{|c|}{$101,3 \%$} & 96,4 & & $95,7 \%$ & \\
\hline & HIDR+ BIOMASSA & & $84,5 \%$ & & & $1,9 \%$ & 100 , & & $103,4^{\circ}$ & \\
\hline HID & $\mathrm{DR}+\mathrm{BIOMASSA}+\mathrm{F}$ & $\mathrm{EOL}$ & $85,0 \%$ & & & $2,5 \%$ & 101, & & $104,8^{\circ}$ & \\
\hline
\end{tabular}




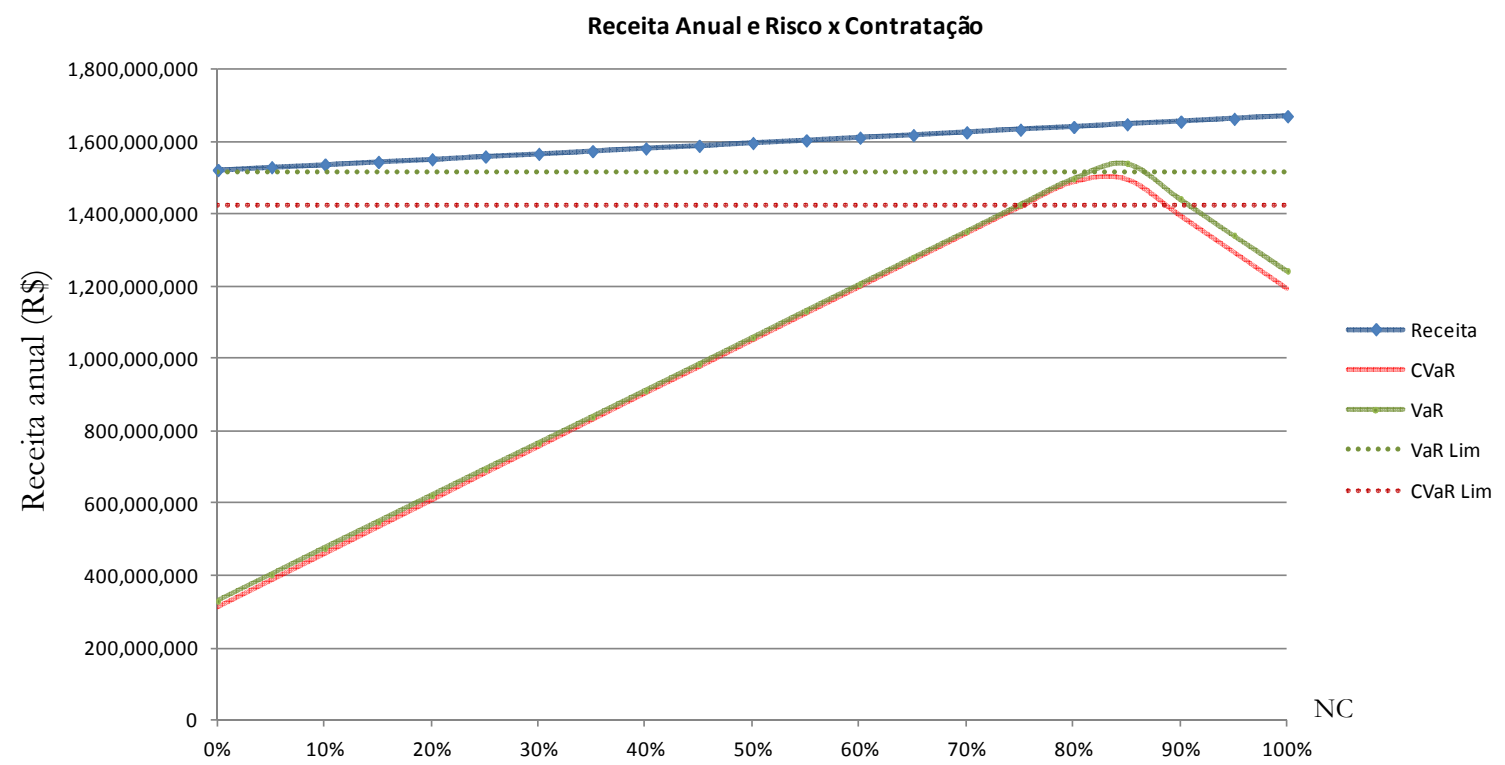

Figura 47 - Receita anual e Parâmetros de Risco $(\mathrm{R} \$) \times N C(\%)$ do portfólio com menor participação de energía eólica (GF critério P50\%) e biomassa em condição de escasseze e preço de venda de $\mathrm{R} \$ 180 / \mathrm{MWh}$ (Fonte: Confecção própria)

Conclui-se que com uma maior GF atribuída à fonte eólica, para os mesmos cenários de geração, não é possível viabilizar a fonte individualmente ou mesmo combinada com a usina de cogeração a biomassa em função da violação das exigências impostas (risco).

No portfólio eólico-hidrelétrico foi necessária a disponibilização de um menor volume para contratação, nível de contratação alterou-se de $90 \%$ para $85 \%$ na carteira cuja participação eólica é mais expressiva e $85 \%$ para $82,5 \%$ na carteira de risco mínimo com o afrouxamento do critério de definição da GF.

O mesmo foi observado na carteira composta pela hidrelétrica e montantes significativos de eólica e biomassa, NC alterou-se de 95\% para 90\%, com isto foi possível elevar o CVaR em R\$ 80 milhões/ano com o inconveniente de provocar a redução na receita esperada em $\mathrm{R} \$ 6$ milhões/ano. Esta nova estratégia de contratação elevou a expectativa de pagamento pela aquisição da curva de geração da eólica e biomassa para $\mathrm{R} \$ 161,20 / \mathrm{MWh}$ frente ao preço mencionado anteriomente (cenário base) de R\$151,80/MWh.

Já na carteira composta por todas as fontes com montantes mais reduzidos das nãoconvencionais, o nível de contratação se manteve, a receita esperada aumentou ( $\mathrm{R} \$ 895 \mathrm{mil} / \mathrm{ano}$ ) em função do incremento de volume vendido advindo da maior GF da eólica, contudo o impacto no CVaR foi de $\mathrm{R} \$ 11$ milhões/ano de redução, o que refletiu na queda do preço para aquisição das fontes alternativas de R\$192,80/MWh para R \$170,80/MWh. 


\subsection{Sensibilidade do Preço de Venda da Energia}

Fez-se uma sensibilidade ao preço de contratação de forma que seu valor seja inferior ao PLD médio esperado. Neste caso o preço de venda da energia seria $\mathrm{R} \$ 160 / \mathrm{MWh}$. Os cenários de receita decrescem na medida em que se aumenta o montante contratado.

Tabela 27 e Tabela 28 - Resultados do Portfólio com participação expressiva de energia eólica e biomassa em condição de escassez e preço de venda de $\mathrm{R} \$ 160 / \mathrm{MWh}$

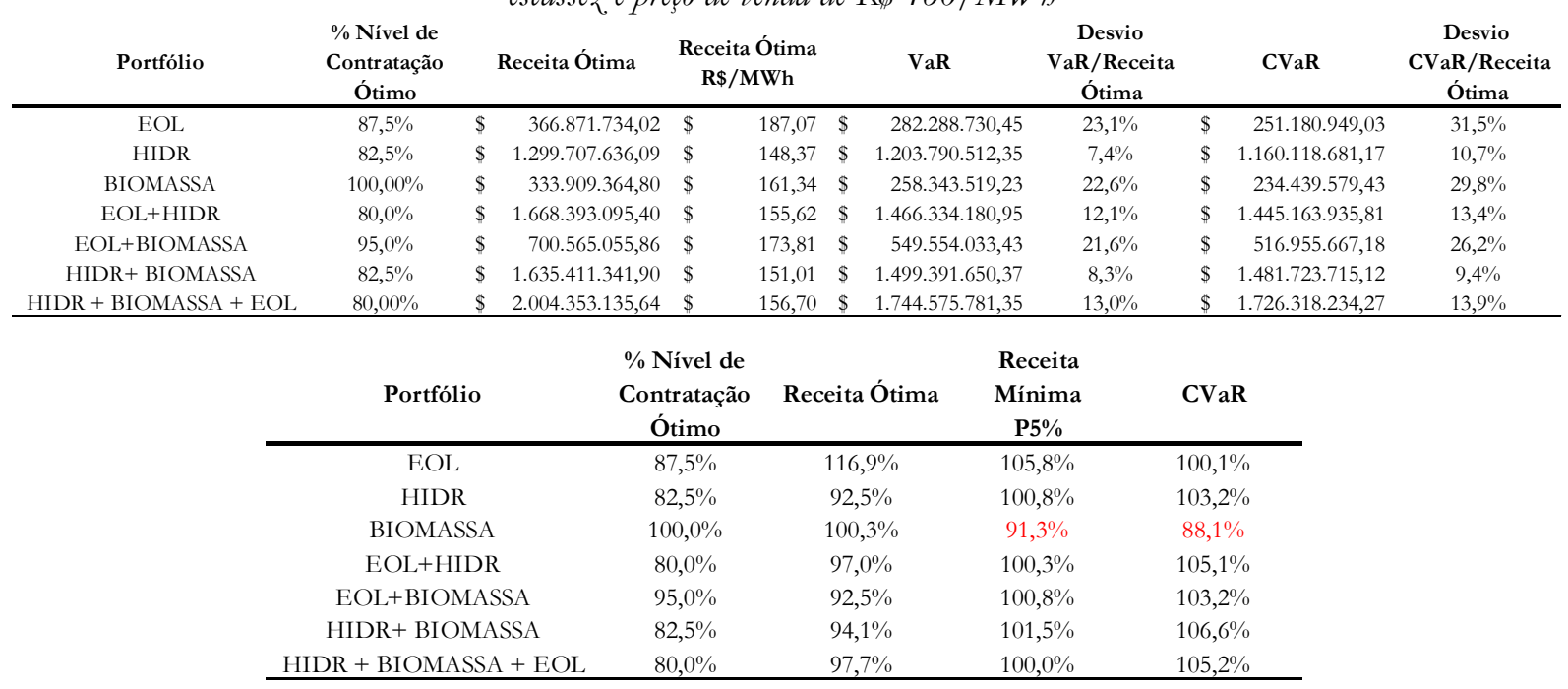

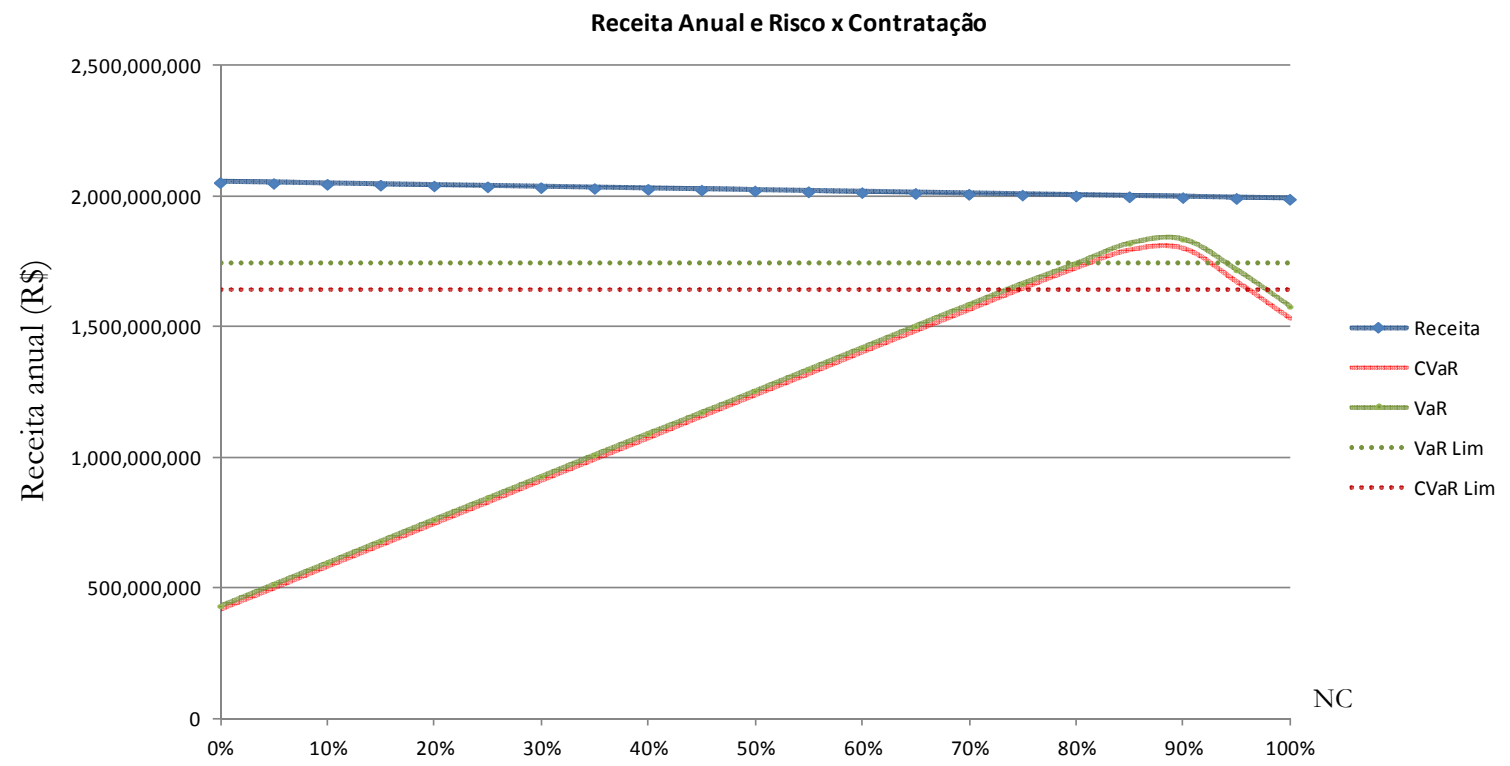

Figura 48 - Receita anual e Parâmetros de Risco (R\$) × NC (\%) do portfólio com participação expressiva de energia eólica e biomassa em condição de escassez e preço de venda de R\$160/MWh (Fonte: Confecção própria) 
Tabela 29 e Tabela 30 - Resultados do Portfólio com menor participação de energia eólica e biomassa (Risco mínimo) em condição de escassez e preço de venda de $\mathrm{R} \$ 160 / \mathrm{MWh}$

\begin{tabular}{|c|c|c|c|c|c|c|c|c|c|c|c|}
\hline Portfólio & $\begin{array}{l}\% \text { Nível de } \\
\text { Contratação } \\
\text { Ótimo }\end{array}$ & & Receita Ótima & & $\begin{array}{l}\text { Ótima } \\
\text { MWh }\end{array}$ & & VaR & $\begin{array}{c}\text { Desvio } \\
\text { VaR/Receita } \\
\text { Ótima }\end{array}$ & & CVaR & $\begin{array}{c}\text { Desvio } \\
\text { CVaR/Receita } \\
\text { Ótima }\end{array}$ \\
\hline EOL & $87,5 \%$ & $\$$ & $97.832 .462,41$ & $\$$ & 187,07 & $\$$ & $75.276 .994,79$ & $23,1 \%$ & $\$$ & $66.981 .586,41$ & $31,5 \%$ \\
\hline HIDR & $82,5 \%$ & $\$$ & 1.299.707.636,09 & $\$$ & 148,37 & $\$$ & $1.203 .790 .512,35$ & $7,4 \%$ & $\$$ & $1.160 .118 .681,17$ & $10,7 \%$ \\
\hline BIOMASSA & $100,00 \%$ & $\$$ & $82.735 .320,39$ & $\$$ & 161,34 & $\$$ & $64.011 .783,10$ & $22,6 \%$ & $\$$ & $58.088 .918,01$ & $29,8 \%$ \\
\hline EOL+HIDR & $82,5 \%$ & $\$$ & $1.397 .669 .647,26$ & $\$$ & 150,56 & $\$$ & $1.287 .835 .727,85$ & $7,9 \%$ & $\$$ & 1.264.010.714,12 & $9,6 \%$ \\
\hline $\mathrm{EOL}+\mathrm{BIOMASSA}$ & $95,0 \%$ & $\$$ & $180.500 .487,59$ & $\$$ & 174,27 & $\$$ & $140.943 .839,83$ & $21,9 \%$ & $\$$ & 133.278.378,45 & $26,2 \%$ \\
\hline HIDR+ BIOMASSA & $82,5 \%$ & $\$$ & $1.382 .887 .554,31$ & $\$$ & 149,13 & $\$$ & $1.282 .265 .967,20$ & $7,3 \%$ & $\$$ & $1.255 .338 .674,83$ & $9,2 \%$ \\
\hline HIDR + BIOMASSA + EOL & $85,00 \%$ & $\$$ & 1.479.636.263,65 & $\$$ & 151,05 & $\$$ & $1.381 .516 .842,28$ & $6,6 \%$ & $\$$ & 1.337.847.464,61 & $9,6 \%$ \\
\hline
\end{tabular}

\begin{tabular}{ccccc} 
Portfólio & $\begin{array}{c}\text { \% Nível de } \\
\text { Contratação } \\
\text { Ótimo }\end{array}$ & Receita Ótima & $\begin{array}{c}\text { Receita } \\
\text { Mínima } \\
\text { P5\% }\end{array}$ & CVaR \\
\hline EOL & $87,5 \%$ & $116,9 \%$ & $105,8 \%$ & $100,1 \%$ \\
HIDR & $82,5 \%$ & $92,5 \%$ & $100,8 \%$ & $103,2 \%$ \\
BIOMASSA & $100,0 \%$ & $100,3 \%$ & $91,3 \%$ & $88,1 \%$ \\
EOL+HIDR & $82,5 \%$ & $93,9 \%$ & $101,7 \%$ & $106,1 \%$ \\
EOL+BIOMASSA & $95,0 \%$ & $108,6 \%$ & $99,8 \%$ & $100,3 \%$ \\
HIDR+ BIOMASSA & $82,5 \%$ & $92,9 \%$ & $101,4 \%$ & $105,5 \%$ \\
HIDR + BIOMASSA + EOL & $85,0 \%$ & $94,1 \%$ & $103,4 \%$ & $106,4 \%$ \\
\hline
\end{tabular}

Pode-se facilmente intuir que com um menor preço de venda da energia a usina a biomassa não se viabiliza, pois não atende às exigências de risco.

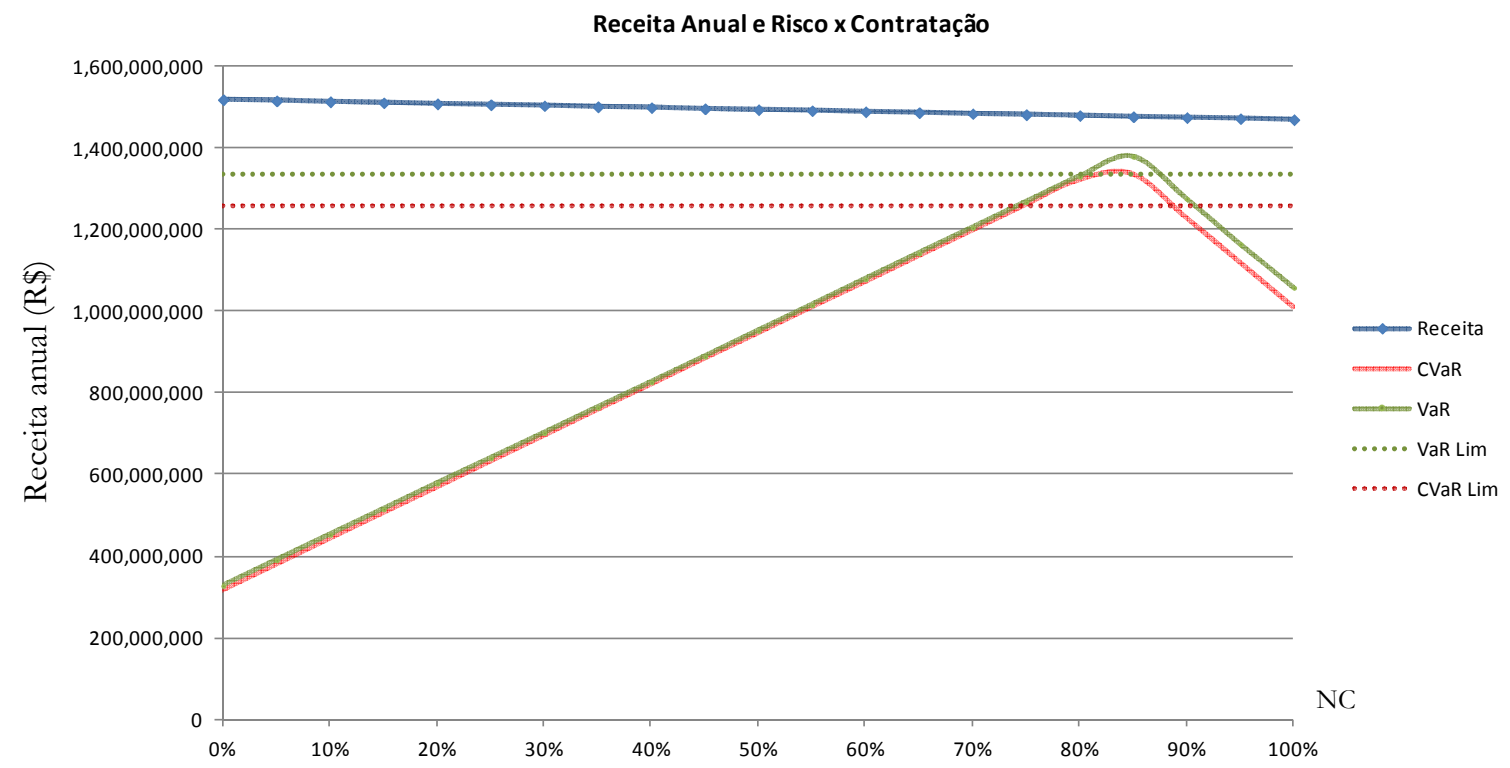

Figura 49 - Receita anual e Parâmetros de Risco (R\$) × NC (\%) do portfólio com menor participação de energia eólica e biomassa em condição de escassez e preço de venda de R\$160/MWh (Fonte: Confecção própria)

Quando o preço de venda considerado é inferior ao preço médio no mercado de curto prazo (PLD) para o período da análise, um nível de contratação mais baixo eleva a expectativa de receita. No entanto a exigência de se atingir os limites de risco faz com que o nível de contratação não reduzisse significativamente em relação à análise quando o preço de contratação supera o PLD. 
Isto é observado para a carteira somente hidrelétrica ou quando se combinam as três fontes e a participação das fontes alternativas é menor. Na análise considerando presença expressiva da eólica e biomassa na carteira inicialmente hidrelétrica pôde-se reduzir o volume disponibilizado à contratação na busca por receitas maiores e atendendo aos critérios de risco. A despeito deste ganho nota-se incremento do risco, pois a parcela descontratada da Garantia Física das plantas é significativa e está sujeita às incertezas dos preços no mercado de curto prazo.

Mais uma vez a combinação das três fontes resultou em maior retorno com nível de risco aceitável e facilmente assimilado pelo empreendedor, o ganho no CVaR foi de 80,6 milhões de reais/ano na carteira com maior participação das fontes alternativas e de 52,7 milhões de reais/ano na carteira de risco mínimo, quando compara-se com a soma do CVaR de cada fonte individualmente.

O preço de compra para alavancar o portfólio com participação mais significativa das fontes alternativas ao nível de risco estabelecido é de até $\mathrm{R} \$ 140,50 / \mathrm{MWh}$, o que representa um deságio superior a $12 \%$ em relação ao preço de venda.

Quando o critério de risco mínimo é utilizado para definir o montante de energia adquirido de usinas a biomassa e eólicas (Portfólio com menor participação das fontes alternativas) o preço para adquirir esta energia pode chegar até $\mathrm{R} \$ 171,60 / \mathrm{MWh}$, o que se traduz em uma valorização de cerca de $7 \%$ em relação ao preço de venda final da energia.

\section{Nível de Contratação Ótimo para diversos preços de contrato}

A figura abaixo ilustra o nível de contratação ótimo para diferentes preços de contrato, no período de 2015-2019, dada as condições de escassez e a ponderação das fontes eólica e a biomassa segundo o risco mínimo. 


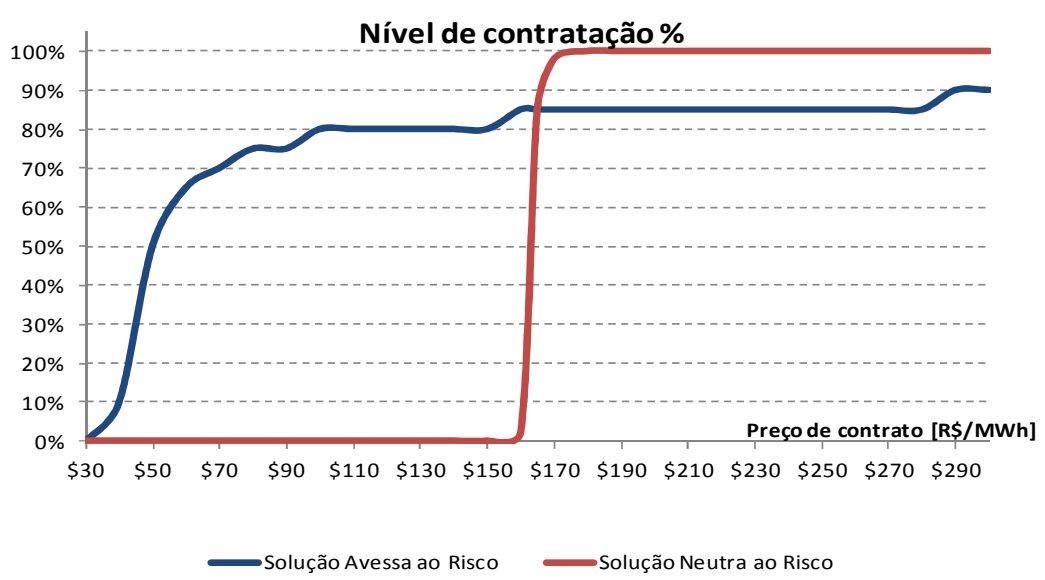

Figura 50 - Nivel de Contratação ótimo vs. preço de venda do porffólio com menor participação de energia eólica e biomassa em condição de escassez. (Fonte: Confecção própria)

Para a solução neutra ao risco, ou seja, que visa à maximização da receita esperada, a decisão de contratar ou não (e em que quantidade) depende essencialmente da relação entre o PLD médio para o período e o preço de venda do contrato. Se o primeiro é maior, então não se contrata nada, e a energia é liquidada na CCEE; se o segundo é maior, então se contrata 100\% da energia disponível. Observe que, o gerador ou está exposto à incerteza do PLD (no caso não se contratar nada) ou à incerteza hidrológica e de geração das fontes intermitentes eólica e biomassa (caso de $100 \%$ de contratação). No entanto, como o objetivo é apenas maximizar a receita esperada, o nível de incerteza associado a esta estratégia não é considerado na decisão.

No caso avesso ao risco, ou seja, quando se atende às exigências de CVaR, e Receita Mínima limites, diferentemente do caso anterior, a decisão sobre a quantidade a ser contratada não depende mais do valor esperado da receita no conjunto completo de cenários previstos, mas sim do que acontece com a mesma nos piores cenários vislumbrados. Resultou, portanto, em nível de contratação baixo para preços de contratos muito baixos, o que se explica pelo fato de que a receita esperada dos contratos, a esses preços, não é compensada pelo aumento que ocorreria no valor do $\mathrm{CVaR}$, caso houvesse contratação. O cenário se altera à medida que o preço do contrato aumenta. Nestes casos, as receita do contrato compensa o risco hidrológico incorrido com o maior nível de contratação.

Nota-se que o nível de contratação permanece acima de $80 \%$ para preços de contrato acima de $\mathrm{R} \$ 100 / \mathrm{MWh}$, e compromete apenas entre $80 \%$ e $90 \%$ da energia disponível. Isto ocorre, pois estratégia procura reduzir significativamente a exposição do gerador ao risco hidrológico e de baixa geração das fontes eólicas e a biomassa, evitando a necessidade de comprar energia no mercado spot em cenários de geração desfavoráveis que, em geral, apresentam PLDs altos. 


\subsection{Sensibilidade de Condições de Partida do Sistema}

A mesma análise pode ser feita para condições de suprimento do sistema mais confortáveis, quando parte-se o sistema com níveis de armazenamento superiores a 80\% da capacidade máxima no início de 2015, o que reduz significativamente o risco de abastecimento e os preços spot e de contratação para o período 2015-2019. Neste caso, o mesmo gerador poderá firmar contratos de longo prazo (2015-2019) por R \$120/MWh aderente às novas condições do sistema.

Tabela 31 e Tabela 32 - Resultados do Portfólio com participação expressiva de energia eólica e biomassa em condição confortável e preço de venda de R\$120/MWh

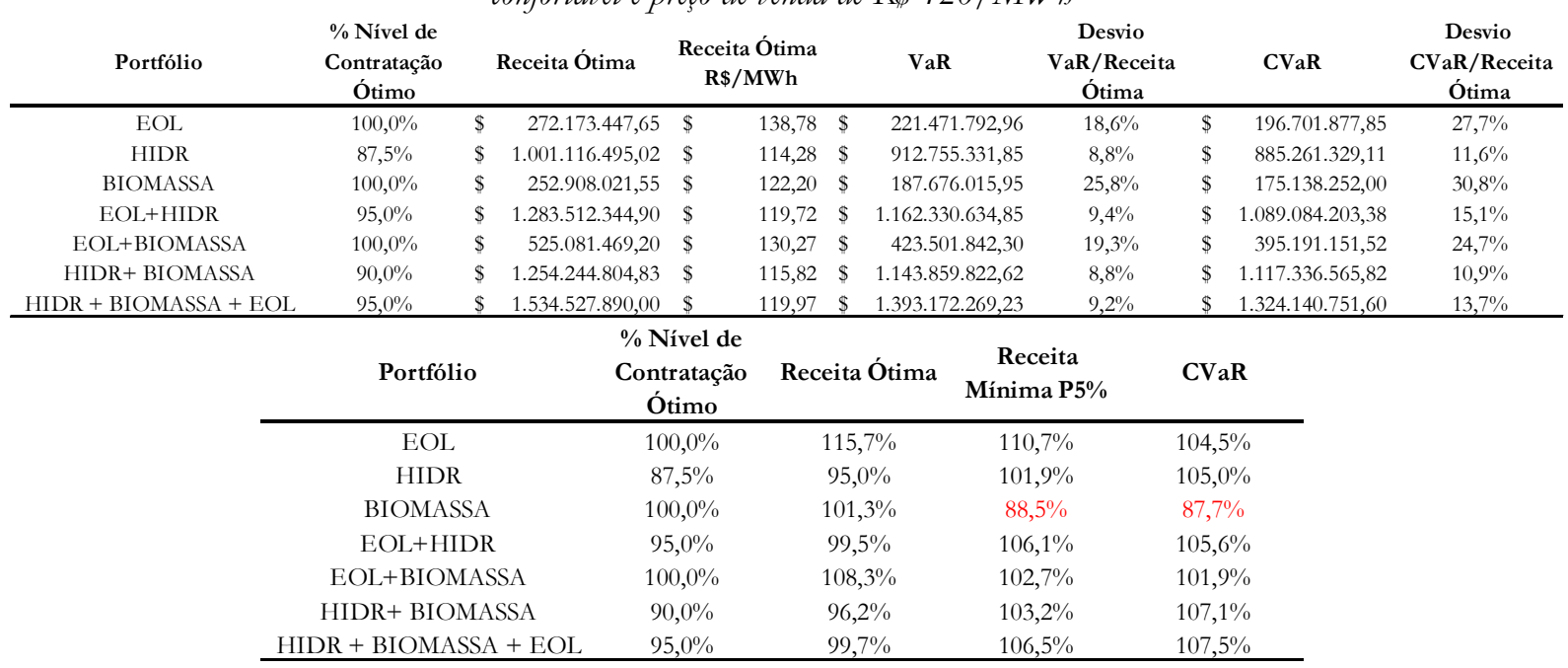

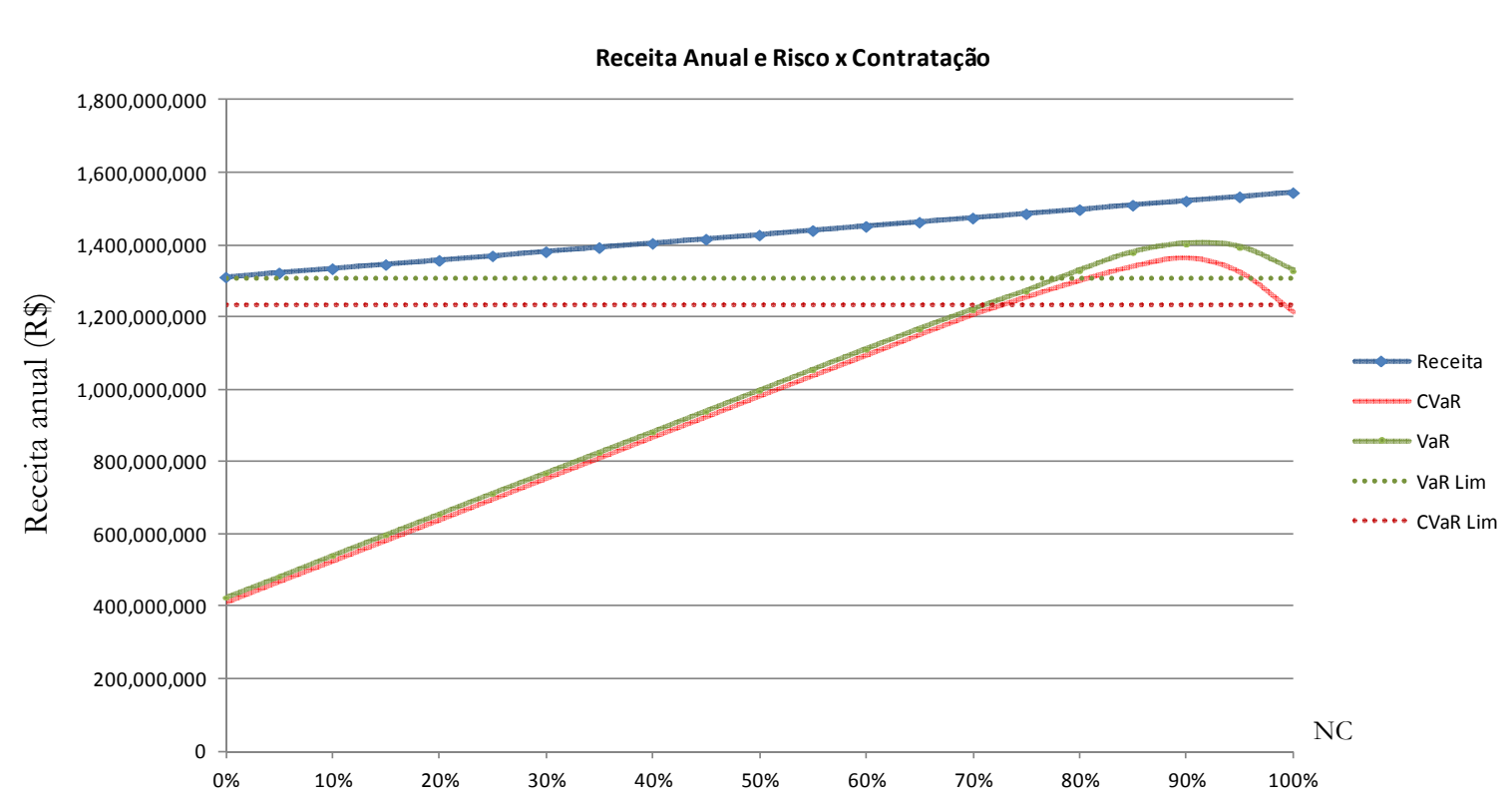

Figura 51 - Receita anual e Parâmetros de Risco (R\$) × NC (\%) do portfólio com participação expressiva de energia eólica e biomassa em condição favorável e preço de venda de R\$120/MWh (Fonte: Confeç̧ão própria) 
Tabela 33 e Tabela 34 - Resultados do Portfólio com menor participação de energia eólica e biomassa (Risco mínimo) em condição favorável e preço de venda de $\mathrm{R} \$ 120 / \mathrm{MWh}$

\begin{tabular}{|c|c|c|c|c|c|c|c|c|c|c|c|}
\hline Portfólio & $\begin{array}{c}\% \text { Nível de } \\
\text { Contratação } \\
\text { Ótimo }\end{array}$ & & Receita Ótima & & $\begin{array}{l}\text { Ótima } \\
\text { MWh }\end{array}$ & & VaR & $\begin{array}{c}\text { Desvio } \\
\text { VaR/Receita } \\
\text { Ótima } \\
\end{array}$ & & CVaR & $\begin{array}{c}\text { Desvio } \\
\text { CVaR/Receita } \\
\text { Ótima }\end{array}$ \\
\hline EOL & $100,0 \%$ & $\$$ & $72.579 .586,04$ & $\$$ & 138,78 & $\$$ & $59.059 .144,79$ & $18,6 \%$ & $\$$ & $52.453 .834,09$ & $27,7 \%$ \\
\hline HIDR & $87,5 \%$ & $\$$ & 1.001.116.495,02 & $\$$ & 114,28 & $\$$ & $912.755 .331,85$ & $8,8 \%$ & $\$$ & $885.261 .329,11$ & $11,6 \%$ \\
\hline BIOMASSA & $100,0 \%$ & $\$$ & $62.664 .987,56$ & $\$$ & 122,20 & $\$$ & $46.501 .946,17$ & $25,8 \%$ & $\$$ & $43.395 .366,88$ & $30,8 \%$ \\
\hline $\mathrm{EOL}+\mathrm{HIDR}$ & $90,0 \%$ & $\$$ & $1.076 .744 .884,22$ & $\$$ & 115,99 & $\$$ & $981.552 .096,13$ & $8,8 \%$ & $\$$ & $941.965 .011,33$ & $12,5 \%$ \\
\hline $\mathrm{EOL}+\mathrm{BIOMASSA}$ & $100,0 \%$ & $\$$ & $135.244 .573,60$ & $\$$ & 130,58 & $\$$ & $109.388 .394,59$ & $19,1 \%$ & $\$$ & $101.690 .784,07$ & $24,8 \%$ \\
\hline HIDR+ BIOMASSA & $90,0 \%$ & $\$$ & $1.066 .848 .896,53$ & $\$$ & 115,05 & $\$$ & $957.247 .658,28$ & $10,3 \%$ & $\$$ & $921.220 .977,65$ & $13,7 \%$ \\
\hline HIDR + BIOMASSA + EOL & $90,0 \%$ & $\$$ & $1.138 .472 .044,56$ & $\$$ & 116,22 & $\$$ & $1.052 .855 .145,18$ & $7,5 \%$ & $\$$ & $1.009 .678 .638,70$ & $11,3 \%$ \\
\hline
\end{tabular}

\begin{tabular}{ccccc} 
Portfólio & $\begin{array}{c}\text { \% Nível de } \\
\text { Contratação } \\
\text { Ótimo }\end{array}$ & Receita Ótima & $\begin{array}{c}\text { Receita } \\
\text { Mínima P5\% }\end{array}$ & CVaR \\
\hline EOL & $100,0 \%$ & $115,7 \%$ & $110,7 \%$ & $104,5 \%$ \\
HIDR & $87,5 \%$ & $95,0 \%$ & $101,9 \%$ & $105,0 \%$ \\
BIOMASSA & $100,0 \%$ & $101,3 \%$ & $88,5 \%$ & $87,7 \%$ \\
EOL+HIDR & $90,0 \%$ & $96,4 \%$ & $103,4 \%$ & $105,4 \%$ \\
EOL+BIOMASSA & $100,0 \%$ & $108,5 \%$ & $103,3 \%$ & $102,0 \%$ \\
HIDR+ BIOMASSA & $90,0 \%$ & $95,6 \%$ & $100,9 \%$ & $103,2 \%$ \\
HIDR + BIOMASSA + EOL & $90,0 \%$ & $96,6 \%$ & $105,1 \%$ & $107,1 \%$ \\
\hline
\end{tabular}

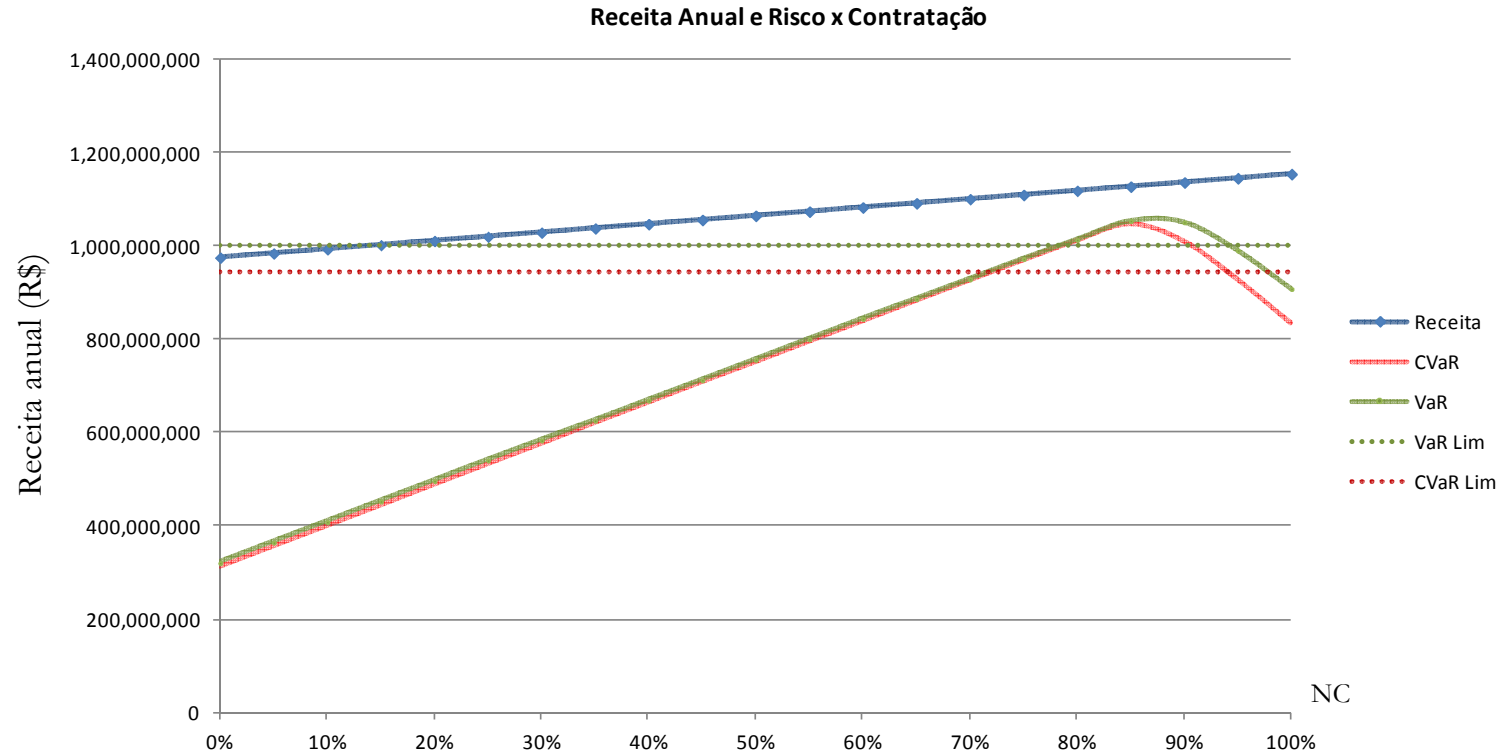

Figura 52 - Receita anual e Parâmetros de Risco (R\$) × NC (\%) do portfólio com menor participação de energia eólica e biomassa em condição favorável e preço de venda de $\mathrm{R} \$ 120 / \mathrm{MWh}$ (Fonte: Confecção própria)

As condições de abastecimento mais favoráveis implicam em ganhos de receita média menores, em contrapartida os riscos de exposição a que as fontes estão submetidas também são significativamente inferiores, o que permite elevar o nível de contratação das carteiras garantindo uma receita fixa advinda da contratação maior, isto em razão do preço de venda considerado ser superior ao preço spot médio do horizonte da análise.

O maior retorno apontado nos portfólios compostos pelas fontes eólicas e a biomassa, individualmente ou em conjunto, é válido independente das reais condições energéticas do 
sistema. Mais uma vez o risco destes portfólios também é significativo. A carteira formada pela combinação das três fontes é a que apresenta a melhor relação de custo-benefício tanto do ponto de vista de receita quanto de risco (posição dominante), uma vez que de todas as opções possíveis que contemplam a fonte hidrelétrica é a que apresenta maior retorno e menor risco. Seguida pela carteira composta pela hídrica e eólica.

O ganho no CVaR com a combinação das três fontes foi de 67 milhões de reais/ano na carteira com maior participação das fontes alternativas e de 28,6 milhões de reais/ano na carteira de risco mínimo, quando se compara com a soma do $\mathrm{CVaR}$ de cada fonte individualmente. Pode-se pagar o valor de até R \$ 120,2/MWh para adquirir energia das fontes alternativas quando a participação das mesmas na carteira é definida de acordo com o critério de Risco Mínimo.

A exemplo das simulações anteriores, à medida que se aumenta a ponderação destas fontes na composição da carteira o preço a ser pago deve incluir um deságio de $\mathrm{R} \$ 11,10 / \mathrm{MWh}$ em relação ao preço de venda de R \$120,00/MWh. No entanto a fim de se avaliar apenas os impactos que a alteração da condição de abastecimento do sistema de mais estressada para mais confortável pode provocar na estratégia de comercialização, replicou-se a análise acima para o preço de venda de $\mathrm{R}$ \$ 160/MWh a fim de compará-lo à análise feita para o preço de venda em questão quando as condições do sistema não eram favoráveis.

Tabela 35 e Tabela 36 - Resultados do Portfólio com participação expressiva de energia eólica e biomassa em condição favorável e preço de venda de $\mathrm{R} \$ 160 / \mathrm{MWh}$

\begin{tabular}{|c|c|c|c|c|c|c|c|c|c|c|c|c|c|}
\hline Portfólio & $\begin{array}{c}\% \text { Nível de } \\
\text { Contratação } \\
\text { Ótimo } \\
\end{array}$ & \multicolumn{3}{|c|}{ Receita Ótima } & \multicolumn{2}{|c|}{$\begin{array}{c}\text { Receita Ótima } \\
\mathbf{R} \$ / \mathbf{M W h}\end{array}$} & & \multicolumn{4}{|c|}{$\begin{array}{c}\text { Desvio } \\
\text { VaR/Receita } \\
\text { Ótima }\end{array}$} & CVaR & \multirow{2}{*}{$\begin{array}{c}\begin{array}{c}\text { Desvio } \\
\text { CVaR/Receita } \\
\text { Ótima }\end{array} \\
21,5 \%\end{array}$} \\
\hline EOL & $100,0 \%$ & $\$$ & 350.661 & 17,00 & $\$$ & 178,81 & $\$$ & 300.088 & 12,47 & $14,4 \%$ & $\$$ & $275.192 .412,76$ & \\
\hline HIDR & $90,0 \%$ & $\$$ & 1.320 .654 & 36,18 & $\$$ & 150,76 & $\$$ & 1.206 .27 & 74,85 & $8,7 \%$ & $\$$ & $1.168 .870 .336,70$ & $11,5 \%$ \\
\hline BIOMASSA & $100,0 \%$ & $\$$ & 335.735 & 81,55 & $\$$ & 162,23 & $\$$ & 270.458 & 15,95 & $19,4 \%$ & $\$$ & $257.950 .492,00$ & $23,2 \%$ \\
\hline $\mathrm{EOL}+\mathrm{HIDR}$ & $100,0 \%$ & $\$$ & 1.722 .395 & 17,84 & $\$$ & 160,65 & $\$$ & 1.517 .02 & 43,85 & $11,9 \%$ & $\$$ & 1.421.517.687,20 & $17,5 \%$ \\
\hline EOL+BIOMASSA & $100,0 \%$ & $\$$ & 686.396 & 98,55 & $\$$ & 170,29 & $\$$ & 584.72 & 28,26 & $14,8 \%$ & $\$$ & $556.476 .733,07$ & $18,9 \%$ \\
\hline HIDR+ BIOMASSA & $95,0 \%$ & $\$$ & 1.675 .896 & 55,61 & $\$$ & 154,75 & $\$$ & 1.505 .16 & 52,94 & $10,2 \%$ & $\$$ & $1.437 .811 .190,62$ & $14,2 \%$ \\
\hline \multirow[t]{9}{*}{ HIDR + BIOMASSA + EO } & $100,0 \%$ & $\$$ & 2.058.131. & 99,38 & $\$$ & 160,91 & $\$$ & 1.840 .77 & 31,38 & $10,6 \%$ & $\$$ & 1.725.115.000,83 & $16,2 \%$ \\
\hline & \multicolumn{3}{|c|}{ Portfólio } & $\begin{array}{r}\% \mathrm{~N} \\
\text { Cont } \\
\text { Ó } \\
\end{array}$ & $\begin{array}{l}\text { ível de } \\
\text { ratação } \\
\text { imo } \\
\end{array}$ & Rec & eita & Ótima & $\begin{array}{r}\text { Rec } \\
\text { Mín } \\
\text { P } \\
\end{array}$ & $\begin{array}{l}\text { ita } \\
\text { ma } \\
\%\end{array}$ & \multicolumn{2}{|c|}{ CVaR } & \\
\hline & \multicolumn{3}{|c|}{ EOL } & & $0,0 \%$ & & 111,8 & & 112 & & \multicolumn{2}{|c|}{$109,6 \%$} & \\
\hline & \multicolumn{3}{|c|}{ HIDR } & \multicolumn{2}{|c|}{$90,0 \%$} & \multicolumn{3}{|c|}{$94,0 \%$} & 101 & & \multicolumn{2}{|c|}{$104,0 \%$} & \\
\hline & \multicolumn{3}{|c|}{ BIOMASSA } & \multicolumn{2}{|c|}{$100,0 \%$} & \multicolumn{3}{|c|}{$100,9 \%$} & 95 , & & \multicolumn{2}{|c|}{$96,9 \%$} & \\
\hline & \multicolumn{3}{|c|}{ EOL+HIDR } & \multicolumn{2}{|c|}{$100,0 \%$} & \multicolumn{3}{|c|}{$100,2 \%$} & 103 & & \multicolumn{2}{|c|}{$103,4 \%$} & \\
\hline & \multicolumn{3}{|c|}{$\mathrm{EOL}+\mathrm{BIOMASSA}$} & \multicolumn{2}{|c|}{$100,0 \%$} & \multicolumn{3}{|c|}{$106,2 \%$} & 106 & & \multicolumn{2}{|c|}{$107,6 \%$} & \\
\hline & \multicolumn{3}{|c|}{ HIDR+ BIOMASSA } & \multicolumn{2}{|c|}{$95,0 \%$} & & 96,4 & & 101 & & 103,4 & & \\
\hline & $\mathrm{HIDR}+\mathrm{BIOM}$ & $S$ SA & $+\mathrm{EOL}$ & & $0,0 \%$ & & 100,3 & & 105 & & 105,1 & & \\
\hline
\end{tabular}




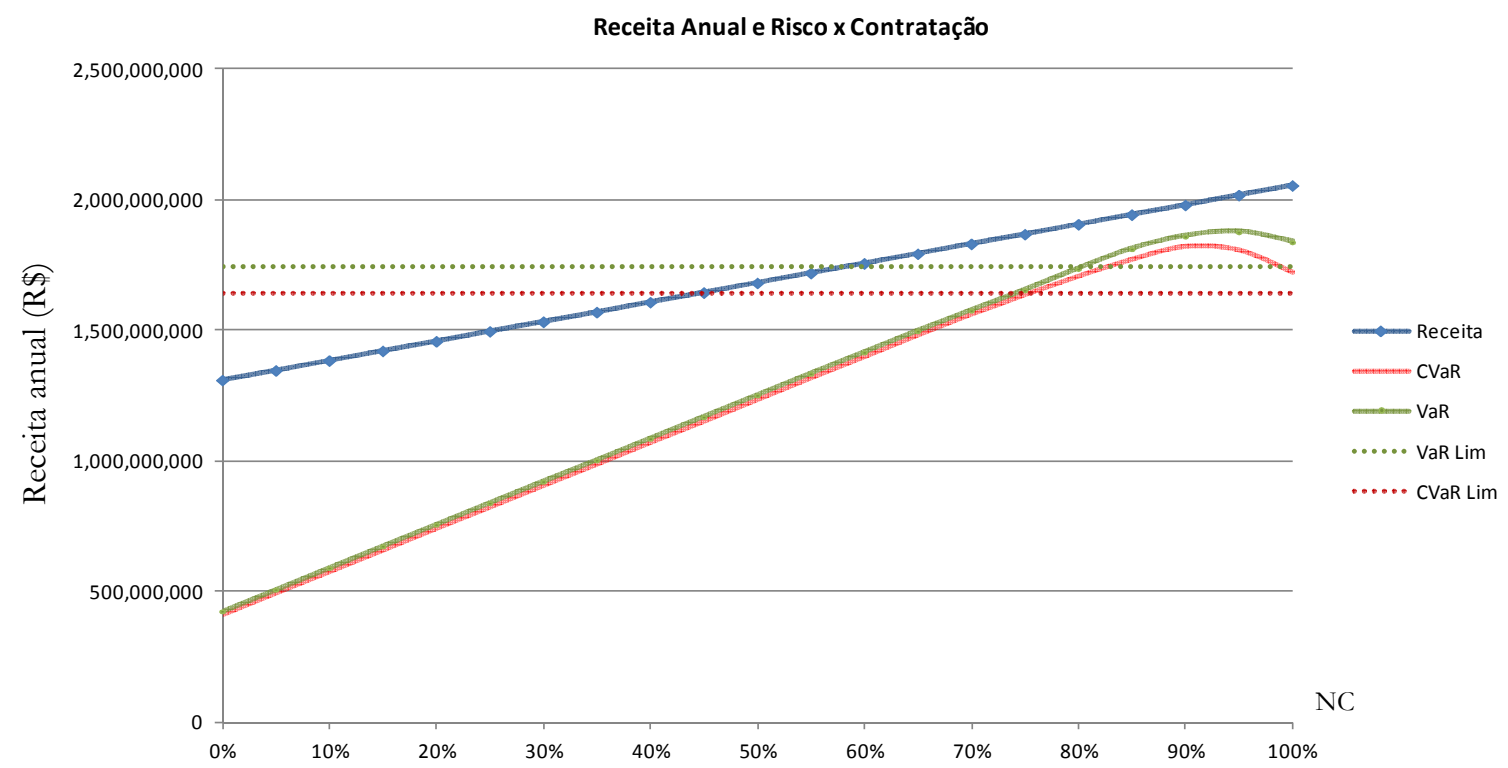

Figura 53 - Receita anual e Parâmetros de Risco (R\$) x NC (\%) do portfólio com participação expressiva de energia eólica e biomassa em condição favorável e preço de venda de R\$160/MWh (Fonte: Confecção própria)

Tabela 37 e Tabela 38 - Resultados do Portfólio com menor participação de energia eólica e biomassa (Risco mínimo) em condição favorável e preço de venda de $\mathrm{R} \$ 160 / \mathrm{MWh}$

\begin{tabular}{|c|c|c|c|c|c|c|c|c|c|c|c|}
\hline Portfólio & $\begin{array}{l}\text { \% Nível de } \\
\text { Contratação } \\
\text { Ótimo }\end{array}$ & & Receita Ótima & & $\begin{array}{l}\text { Ótima } \\
\text { MWh }\end{array}$ & & VaR & $\begin{array}{c}\text { Desvio } \\
\text { VaR/Receita } \\
\text { Ótima } \\
\end{array}$ & & CVaR & $\begin{array}{c}\text { Desvio } \\
\text { CVaR/Receita } \\
\text { Ótima } \\
\end{array}$ \\
\hline EOL & $100,0 \%$ & $\$$ & $93.509 .631,20$ & $\$$ & 178,81 & $\$$ & $80.023 .576,66$ & $14,4 \%$ & $\$$ & $73.384 .643,40$ & $21,5 \%$ \\
\hline HIDR & $90,0 \%$ & $\$$ & $1.320 .654 .536,18$ & $\$$ & 150,76 & $\$$ & $1.206 .274 .674,85$ & $8,7 \%$ & $\$$ & $1.168 .870 .336,70$ & $11,5 \%$ \\
\hline BIOMASSA & $100,0 \%$ & $\$$ & $83.187 .766,76$ & $\$$ & 162,23 & $\$$ & 67.013.486,17 & $19,4 \%$ & $\$$ & 63.914.399,68 & $23,2 \%$ \\
\hline $\mathrm{EOL}+\mathrm{HIDR}$ & $95,0 \%$ & $\$$ & 1.438.179.528,45 & $\$$ & 154,93 & $\$$ & 1.279.936.998,02 & $11,0 \%$ & $\$$ & 1.218.696.399,29 & $15,3 \%$ \\
\hline $\mathrm{EOL}+\mathrm{BIOMASSA}$ & $100,0 \%$ & $\$$ & 176.697.397,96 & $\$$ & 170,60 & $\$$ & $150.818 .517,51$ & $14,6 \%$ & $\$$ & 143.136.041,28 & $19,0 \%$ \\
\hline HIDR+ BIOMASSA & $90,0 \%$ & $\$$ & $1.400 .852 .197,81$ & $\$$ & 151,07 & $\$$ & $1.291 .068 .044,28$ & $7,8 \%$ & $\$$ & $1.255 .041 .363,65$ & $10,4 \%$ \\
\hline HIDR + BIOMASSA + EOL & $95,0 \%$ & $\$$ & $1.519 .872 .242,64$ & $\$$ & 155,16 & $\$$ & 1.364.587.169,97 & $10,2 \%$ & $\$$ & 1.300.367.340,99 & $14,4 \%$ \\
\hline
\end{tabular}

\begin{tabular}{ccccc} 
Portfólio & $\begin{array}{c}\text { \% Nível de } \\
\text { Contratação } \\
\text { Ótimo }\end{array}$ & Receita Ótima & $\begin{array}{c}\text { Risco Mínimo } \\
\text { P5\% }\end{array}$ & CVaR \\
\hline EOL & $100,0 \%$ & $111,8 \%$ & $112,5 \%$ & $109,6 \%$ \\
HIDR & $90,0 \%$ & $94,0 \%$ & $101,0 \%$ & $104,0 \%$ \\
BIOMASSA & $100,0 \%$ & $100,9 \%$ & $95,6 \%$ & $96,9 \%$ \\
EOL+HIDR & $95,0 \%$ & $96,6 \%$ & $101,1 \%$ & $102,3 \%$ \\
EOL+BIOMASSA & $100,0 \%$ & $106,4 \%$ & $106,8 \%$ & $107,7 \%$ \\
HIDR+ BIOMASSA & $90,0 \%$ & $94,1 \%$ & $102,1 \%$ & $105,4 \%$ \\
HIDR + BIOMASSA + EOL & $95,0 \%$ & $96,7 \%$ & $102,2 \%$ & $103,4 \%$ \\
\hline
\end{tabular}




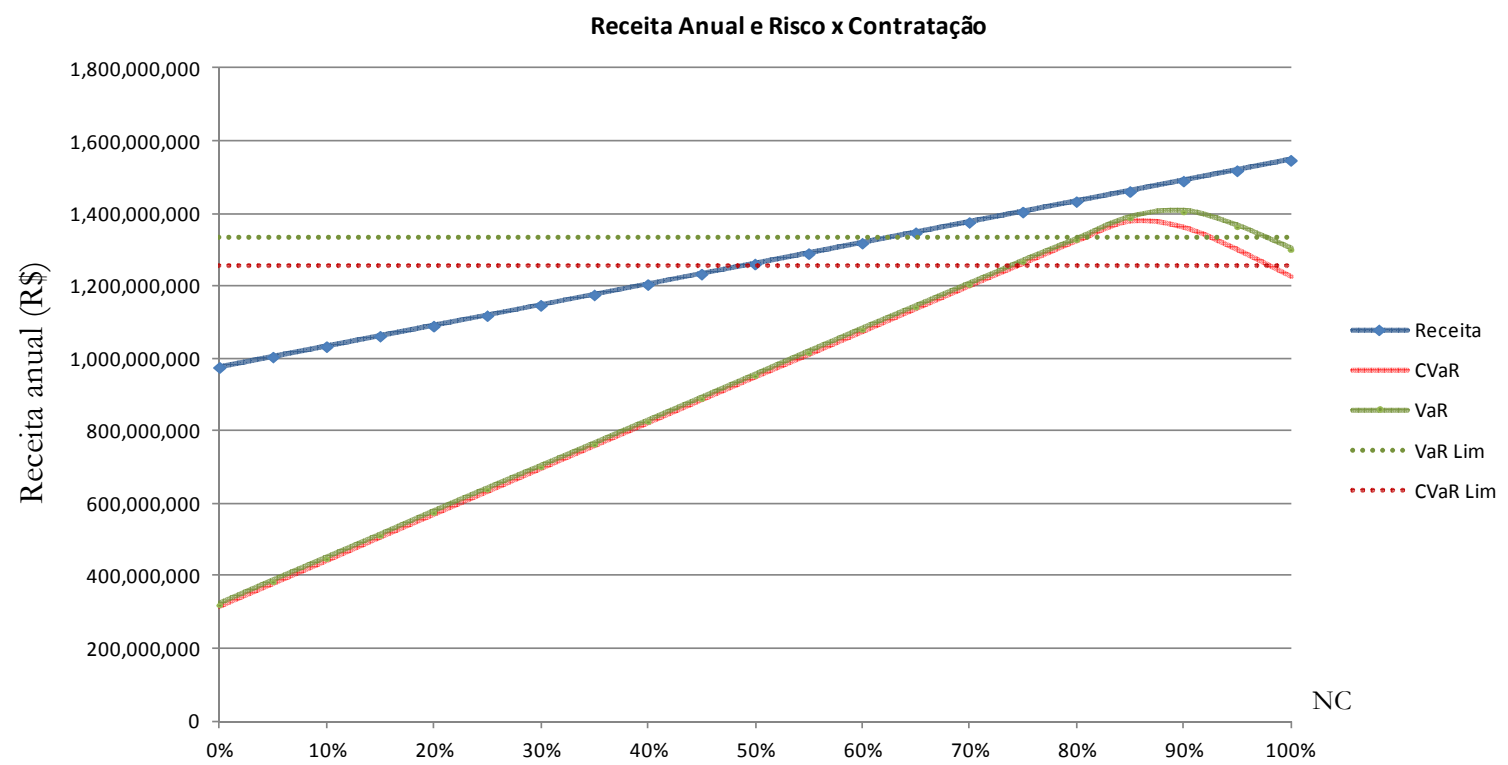

Figura 54 - Receita anual e Parâmetros de Risco (R\$) × NC (\%) do portfólio com menor participação de energia eólica e biomassa em condição favorável e preço de venda de R\$160/MWh (Fonte: Confecção própria)

Uma condição energética do sistema mais favorável implica em níveis de risco significativamente inferiores para as carteiras compostas pelas fontes eólica e/ou a biomassa. O portfólio formado apenas pela usina a biomassa, embora apresente um dos maiores retornos esperados, ainda não atende às condições de risco impostas mesmo quando se combina condições de abastecimento do sistema mais confortáveis e um preço de venda elevado ( $\$$ \$160/MWh) nesta ocasião. Já as carteiras formadas pela fonte eólica somente e eólica e biomassa tornam-se viáveis para o preço proposto de contratação - R \$160/MWh.

A condição de partida mais favorável também permitiu elevar o nível de contratação, principalmente nos portfólios com predominância hidrelétrica, com a possibilidade de auferir ganhos maiores na receita esperada. Entretanto, a estratégia corroborou com um aumento nos valores de risco - VaR e CVaR embora ainda a níveis aceitáveis. Neste contexto, é necessário um deságio no preço de compra da curva de geração das fontes eólicas e biomassa em ambas as situações de ponderação destas fontes na carteira, com participação mínima pode-se pagar até $\mathrm{R} \$ 138,00 / \mathrm{MWh}$, já com presença maciça a análise conduz a um preço de compra de $\mathrm{R} \$ 126,96 / \mathrm{MWh}$.

\subsection{Sensibilidade à Restrição de Risco}

As análises realizadas até agora consideraram um modelo calibrado para otimizar o CVaR, com um valor limite mínimo de $80 \%$ da Receita de Referência, enquanto que o VaR limite calibrado 
foi obtido para uma Receita Mínima equivalente a $85 \%$. O risco assumido de valores fora dessa faixa foi de $5 \%$.

Dado o portfólio formado por todas as fontes de geração na ponderação segundo o risco mínimo, variou-se o critério de risco medido pelo CVaR na faixa de $60 \%$ a $85 \%$ da Receita de Referência e a Receita Mínima na faixa de 65\% a 90\% da mesma Receita de Referência a fim de se averiguar modificações na estratégia de contratação, bem como valores de receita e risco incorridos. Além disso, utilizou-se o critério baseado na maximização do CVaR e fez-se uma sensibilidade com relação ao intervalo de confiança da análise.

O objetivo destas sensibilidades é identificar se pequenas variações no critério de risco ao qual se está exposto podem representar ganhos, em termos de receita, que se justifiquem em uma decisão mais ou menos conservadora.

À medida que os critérios de risco que subsidiam a decisão tornam-se menos rigorosos tem-se a possibilidade que auferir maiores ganhos em média por meio da maior contratação, uma vez que o preço de venda supera o valor esperado de preço spot. Uma consequência do afrouxamento dos limites de risco é o aumento dos desvios entre $\mathrm{VaR}$ e CVaR em relação à Receita esperada, o que representa uma maior dispersão da distribuição dos resultados de receita e a possibilidade de receitas muito reduzidas nos piores cenários.

Tabela 39 e Tabela 40 - Resultados do Portfólio Final com menor participação de energia eólica e biomassa (Risco mínimo) e Preço de venda igual a R\$180/MWh em condição de escassez.

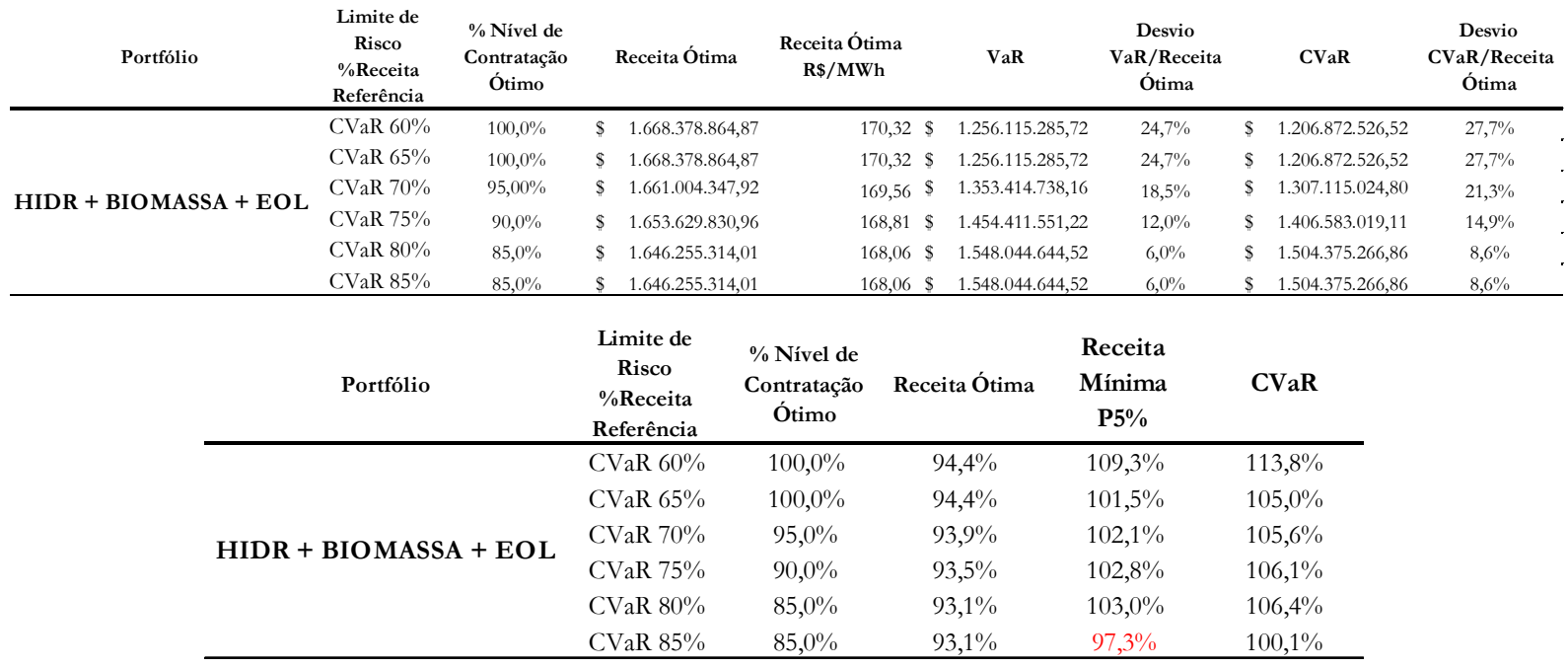


Tabela 41 e Tabela 42 - Resultados do Portfólio Inicial hidrelétrico e Preço de venda igual a R\$180/MWh em condição de

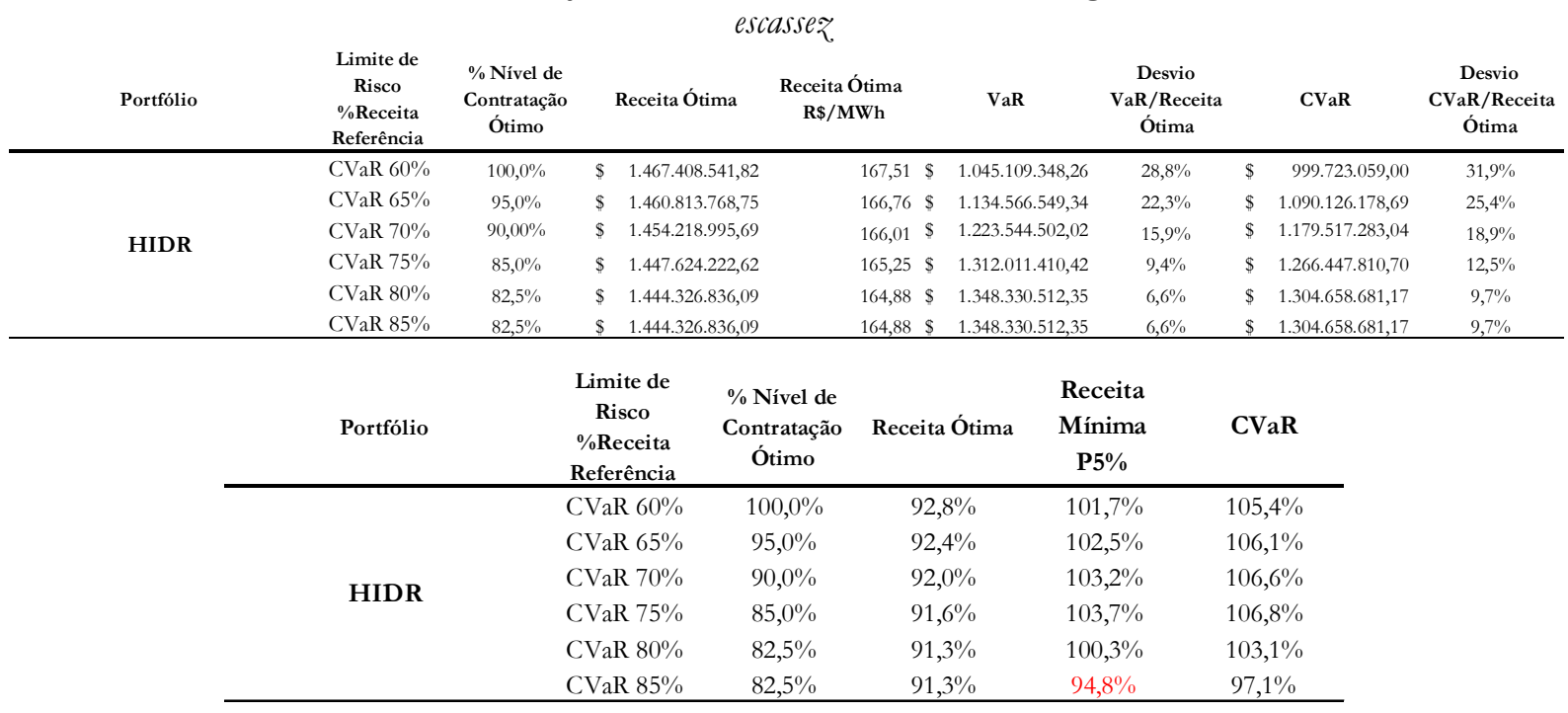

Tabela 43 - Preşo $(\mathrm{R} \$ / M W h)$ de aquisição da curva de geração das fontes alternativas dado o preço de venda de $\mathrm{R} \$ 180 / \mathrm{MWh}$ em condição de escassez.

\begin{tabular}{ccc} 
Portfólio & $\begin{array}{c}\text { Limite de } \\
\text { Risco } \\
\text { \%Receita } \\
\text { Referência }\end{array}$ & $\begin{array}{c}\text { Preço de } \\
\text { aquisição das } \\
\text { fontes } \\
\text { alternativas }\end{array}$ \\
\hline CVaR 60\% & 200,00 \\
HIDR + BIOMASSA + EOL & CVaR 65\% & 112,72 \\
& CVaR 70\% & 123,19 \\
& CVaR 75\% & 135,30 \\
& CVaR 80\% & 192,82 \\
& CVaR 85\% & 192,82 \\
\hline
\end{tabular}

Se o critério de escolha da estratégia de contratação for a maximização do CVaR (critério de risco mínimo) tem-se um nível de contratação ótimo de $85 \%$ para o portfólio final e 82,5\% para o portfólio inicial hidrelétrico. Assim, o preceito de risco utilizado neste trabalho converge para o de maximização do CVaR a partir do $\mathrm{CVaR}_{\text {limite }}$ equivalente a $80 \%$ da Receita de Referência.

É interessante observar que o ganho na receita esperada do portfólio final quando se compara o critério de máxima receita (nível de contratação de 100\%) em relação ao de risco mínimo (nível de contratação de $85 \%$ ) é de $\mathrm{R} \$ 22$ milhões/ano.

Contudo, o risco incorrido aumenta em R $\$ 297,5$ milhões/ano nesta mesma comparação. Ou seja, o aumento no retorno não justifica o aumento no risco. Se, porventura, o preço de venda for inferior ao valor médio do preço spot a tendência é aumentar o volume descontratado à medida que o critério de risco é afrouxado. 
Um critério de risco mais rigoroso ainda inviabilizaria todas as composições de portfólio. A maximização do CVaR ocorre para os níveis de contratação de $85 \%$ para o portfólio final e $82,5 \%$ para o portfólio inicial. Resultado consistente e independente se o preço de venda é superior ou inferior ao preço médio no spot.

Tabela 44 e Tabela 45 - Resultados do Portfólio com menor participação de energia eólica e biomassa (Risco mínimo) e Preço de venda igual a $\mathrm{R} \$ 160 / \mathrm{MWh}$ em condição de escassez.

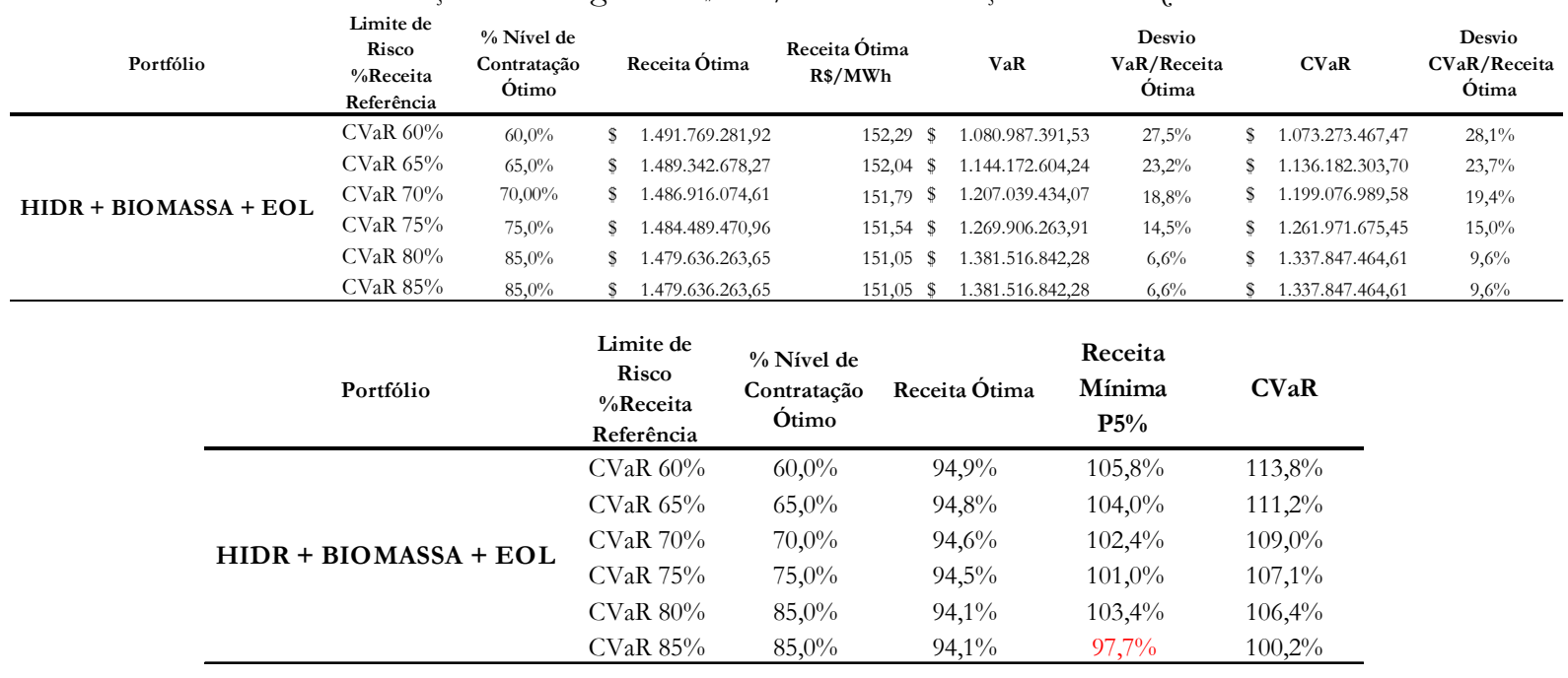

Tabela 46 e Tabela 47 - Resultados do Portfólio hidrelétrico e Preço de venda igual a $\mathrm{R} \$ 160 /$ MWh em condição de

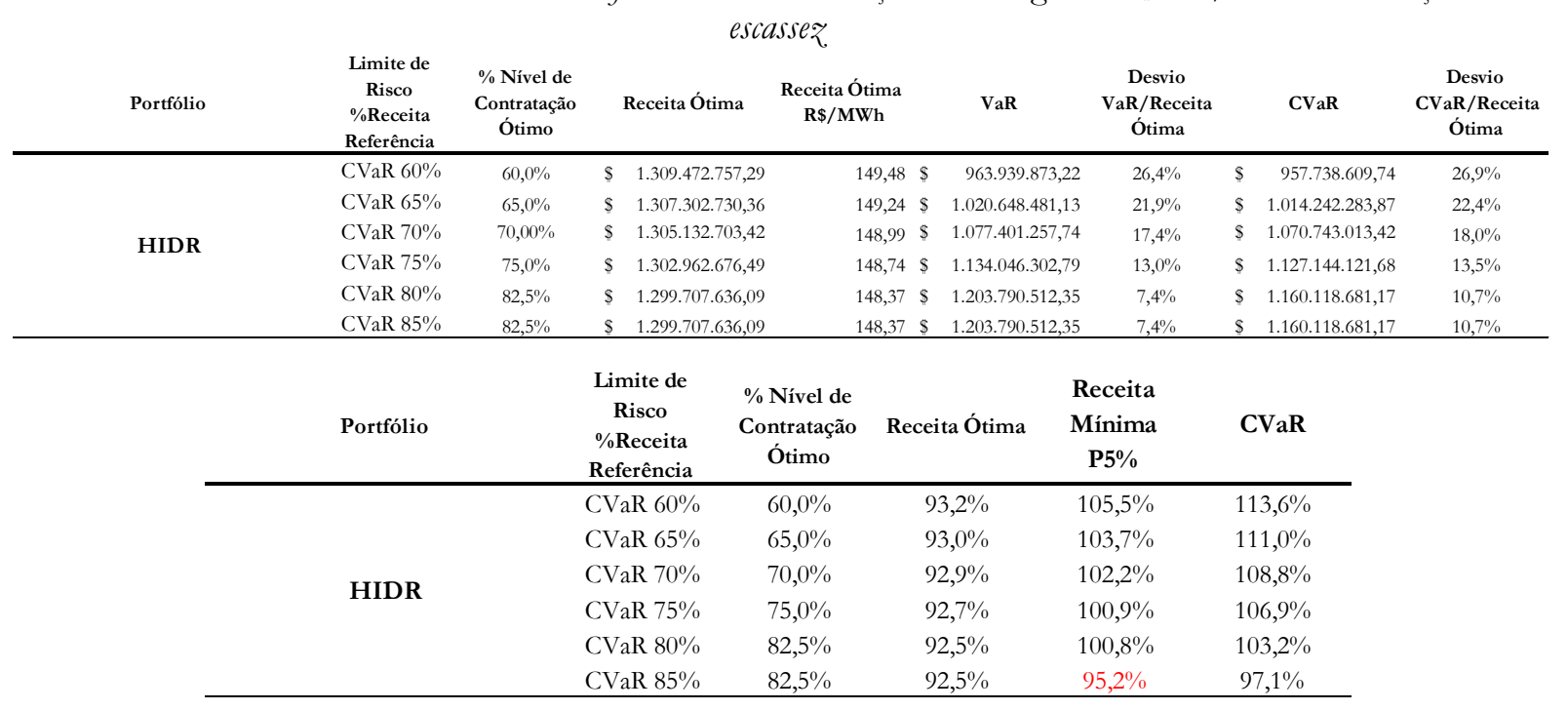


Tabela 48 - Preşo $(\mathrm{R} \$ / M W h)$ de aquisição da curva de geração das fontes alternativas dado o preço de venda de

\begin{tabular}{|c|c|c|}
\hline Portfólio & $\begin{array}{l}\text { Limite de } \\
\text { Risco } \\
\text { \%Receita } \\
\text { Referência }\end{array}$ & $\begin{array}{l}\text { Preço de } \\
\text { aquisição das } \\
\text { fontes } \\
\text { alternativas }\end{array}$ \\
\hline \multirow{6}{*}{ HIDR + BIOMASSA + EOL } & CVaR $60 \%$ & 111,55 \\
\hline & CVaR $65 \%$ & 117,73 \\
\hline & CVaR $70 \%$ & 123,90 \\
\hline & CVaR $75 \%$ & 130,17 \\
\hline & CVaR $80 \%$ & 171,59 \\
\hline & CVaR $85 \%$ & 171,59 \\
\hline
\end{tabular}

O ganho na receita esperada do portfólio final quando se compara o critério de máxima receita esperada (nível de contratação de $0 \%$ ) em relação ao de risco mínimo (nível de contratação de $85 \%$ ) é de $\mathrm{R} \$ 41$ milhões/ano. Contudo, o risco incorrido aumenta em R $\$ 1.023$ milhões/ano nesta mesma comparação. Ou seja, o aumento no retorno não justifica o aumento no risco.

À medida que se afrouxam os critérios de risco a maximização da receita esperada passa a ter mais peso na estratégia de contratação, com isto a mitigação de risco por meio do nível de contratação ótimo e da aquisição da curva de geração de fontes complementares deixa de apresentar efeitos tão significativos. A evolução do preço de aquisição da curva de geração das fontes alternativas demonstra esta constatação. Observa-se que para os critérios de risco em que o CVaR é inferior a $80 \%$ da receita de referência, é necessário um deságio no custo de aquisição em relação ao preço de venda, de forma que a margem obtida contribua para alavancar o portfólio proposto ao nível de risco fixado.

Já para critérios de risco mais rígidos, o efeito da estratégia de comercialização produz resultados mais contundentes na mitigação de risco, podendo-se pagar um preço de compra superior ao preço de venda.

O preço de R \$200/MWh para aquisição da curva de geração das fontes eólica e biomassa frente ao preço de venda de R $\$ 180 / \mathrm{MWh}$ no critério CVaR limite igual a 60\% (Tabela 42) pode ser justificado pelo ganho com a complementaridade energética que a combinação das fontes introduz ao portfólio final totalmente contratado. 


\subsection{Variação do Intervalo de Confiança}

Com um CVaR limite de 80\% da Receita de Referência e um VaR limite calibrado para se obter uma Receita Mínima equivalente a 85\% da mesma Receita de Referência, assumia-se um risco de $5 \%$ de valores fora dessa faixa $(\mathrm{IC}=95 \%)$.

Vejamos agora as variações na estratégia ao variar o nível de confiança da análise.

Tabela 49 e Tabela 50 - Resultados do Portfólio com menor participação de energia eólica e biomassa (Risco minimo) e Preço de venda igual a $\mathrm{R} \$ 180 / \mathrm{MWh}$ em condição de escassez.

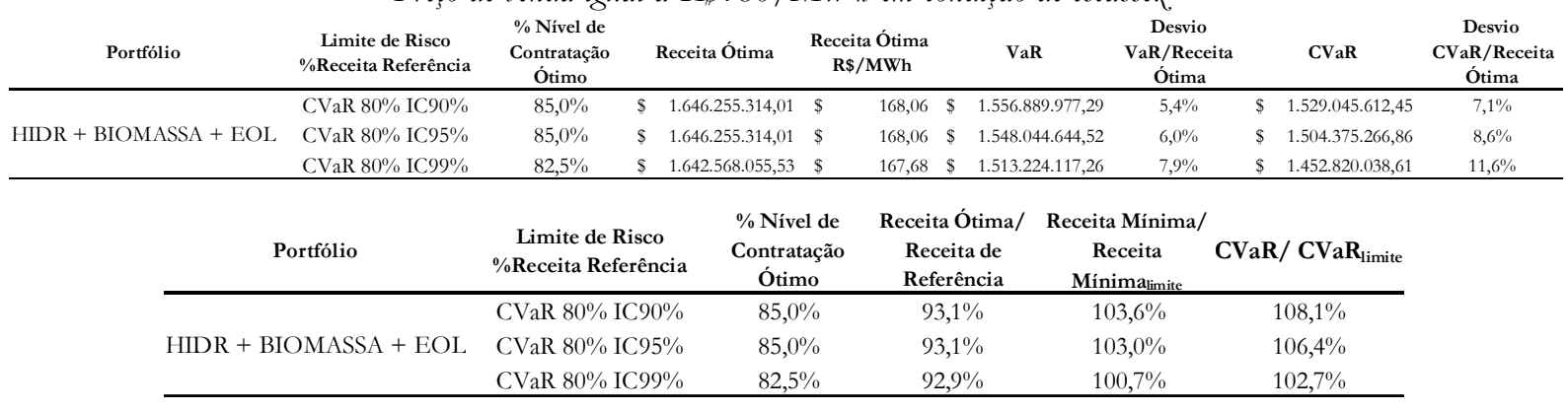

Tabela 51 e Tabela 52 - Resultados do Portfólio bidrelétrico e Preço de venda igual a $\mathrm{R} \$ 180 / \mathrm{MWh}$ em condição de

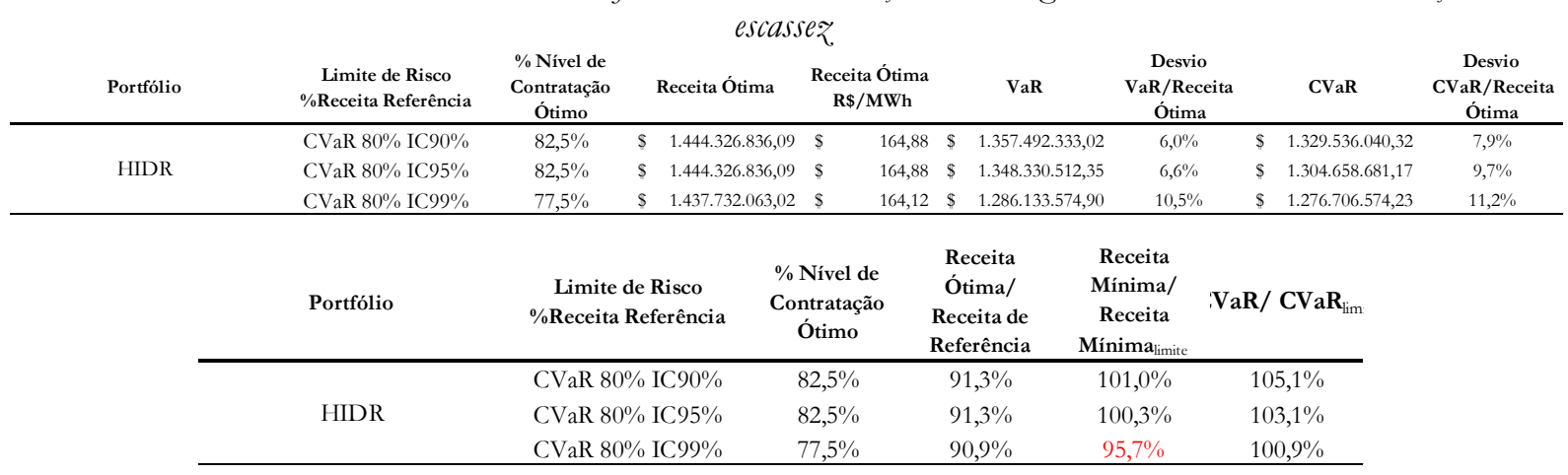

Tabela 53 - Preço (R\$/MWh) de aquisição da curva de geração das fontes alternativas dado o preço de venda de $\mathrm{R} \$ 180 / \mathrm{MWh}$ em condição de escassez.

\begin{tabular}{clcr} 
Portfólio & $\begin{array}{c}\text { Limite de Risco } \\
\text { \%Receita Referência }\end{array}$ & $\begin{array}{c}\text { Preço de } \\
\text { aquisição das } \\
\text { fontes } \\
\text { alternativas }\end{array}$ \\
\hline \multirow{3}{*}{ HIDR + BIOMASSA + EOL } & CVaR $80 \%$ IC $90 \%$ & $\$$ & 192,62 \\
& CVaR 80\% IC95\% & $\$$ & 192,82 \\
& CVaR 80\% IC99\% & $\$$ & 170,03 \\
\hline
\end{tabular}

Quanto maior o nível de confiança (IC) menor é o CVaR pois restringe-se a faixa dos piores cenários de receita ( $\mathrm{CVaR}$ calcula a média desses cenários). O atendimento à exigência de torná-lo no mínimo equivalente a $80 \%$ da Receita de Referência reforça muito a aversão ao risco da 
decisão, de modo que é necessário reduzir o nível de contratação e, consequentemente, a renda esperada, bem como o preço pago de aquisição das fontes de geração alternativas.

\section{8 Índice Risco-Retorno}

Outra maneira de se tomar decisão a respeito da quantidade de energia a ser disponibilizada para contratação é o índice de risco-retorno, baseado na convergência da métrica de risco e retorno nas referências de mínimo risco e de máximo retorno do portfólio. Quanto maior o valor do índice melhor a relação risco-retorno.

É uma boa maneira de identificar se pequenas variações sobre o risco ao qual se está exposto podem representar ganhos de receita que justificam uma decisão mais ou menos conservadora.

Indice Risco - retorno $=\frac{\left(\frac{M e ́ d i a_{i}}{M e ́ d i a_{r e f}}\right)}{\left(\frac{P 95_{I C_{-} r e f}}{P 95_{I C_{-} i}}\right)}$

A métrica de Retorno do portfólio é o valor esperado (Média) da distribuição de cenários de receita, já a métrica de risco é o percentil $5 \%$ da distribuição (equivalente ao VaR), considerando o intervalo de confiança (IC) de 95\% (P95 $\mathrm{IC} \%$ ). Pode-se utilizar outros indicadores de risco, como o CVaR, desvio-padrão.

(Média $a_{i}$, P95 $\left.{ }_{\text {C__i }}\right)$ : Métricas de Risco e retorno para cada nível de contratação “i”

$\left(\right.$ Média $_{\text {ref }}$, P95 $\left.5_{\text {CI_ref }}\right)$ : Métricas de Risco e retorno para a referência

O índice Risco-retorno deve ser calculado para duas referências:

- Nível de Contratação para risco mínimo

- Nível de Contratação para máximo retorno

Fazendo a análise em condição de escassez para o portfólio constituído na ótica de mínimo risco (participação predominante da fonte hidrelétrica) e preço de venda equivalente a $\mathrm{R} \$ 180 / \mathrm{MWh}$ tem-se:

Índice Risco-retorno indicou um nível ótimo de contratação de 87,5\%. Isto por que à medida que se avança do nível de contratação 87,5\% (Melhor índice Risco-retorno e Risco mínimo) até 100\% 
(Retorno Máximo) o acréscimo no retorno é muito inferior que o acréscimo no risco (redução da receita mínima).

Em relação ao resultado do item 10.2 pôde-se avançar em 2,5\% no nível de contratação, pois o incremento no retorno do percentual de contratação $85 \%$ para $87,5 \%$ superou a acréscimo no risco, redução da receita mínima.

\section{Receita anual mínima e esperada em diferentes níveis de contratação}

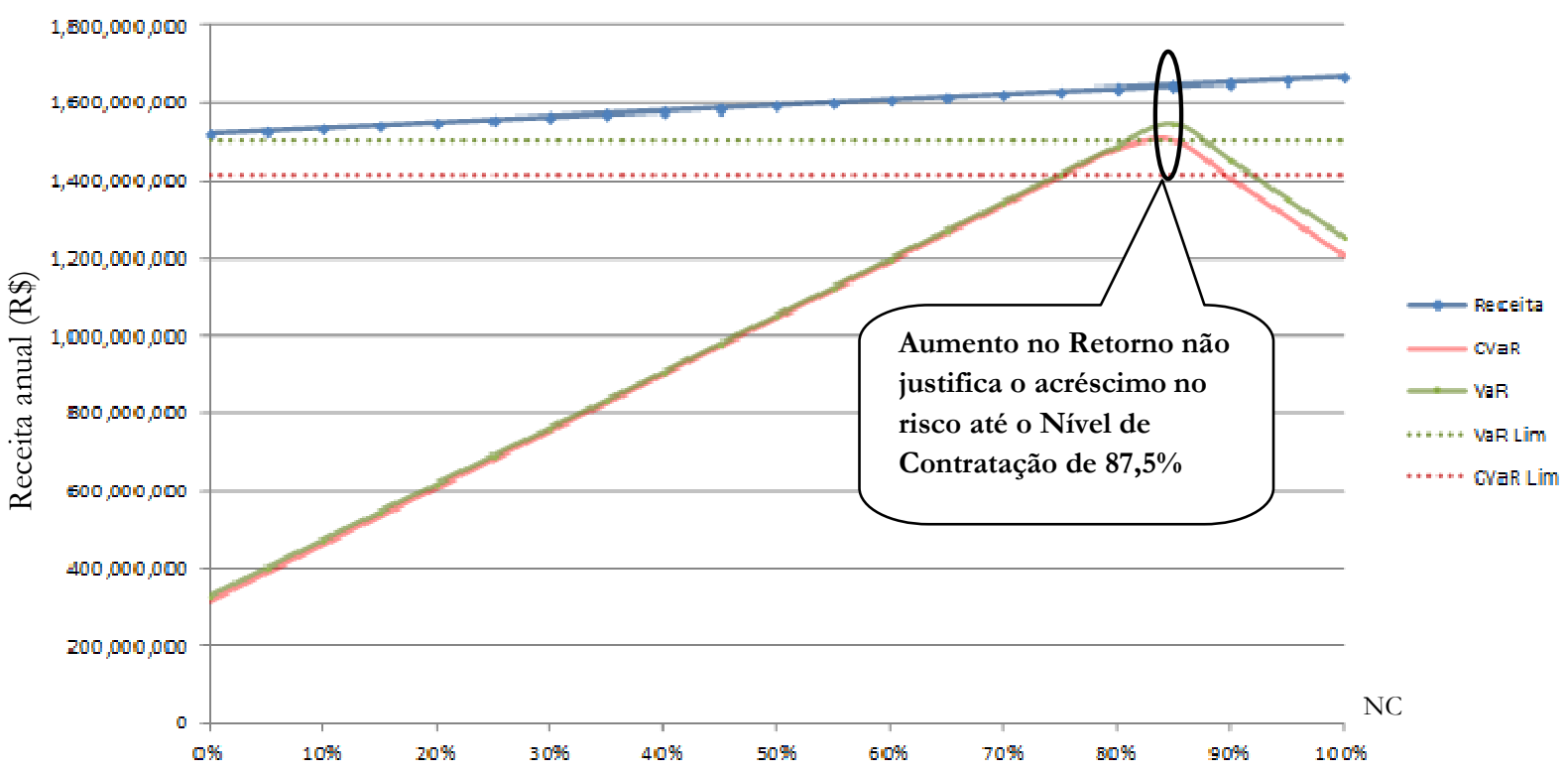

Figura 55 - Receita Esperada x Minima em condição de escassez. e preço de venda $\mathrm{R} \$ 180 / \mathrm{MWh}$ (Fonte: Elaboração própria)

Considerando agora o preço de venda de R \$ 160/MWh tem-se: 


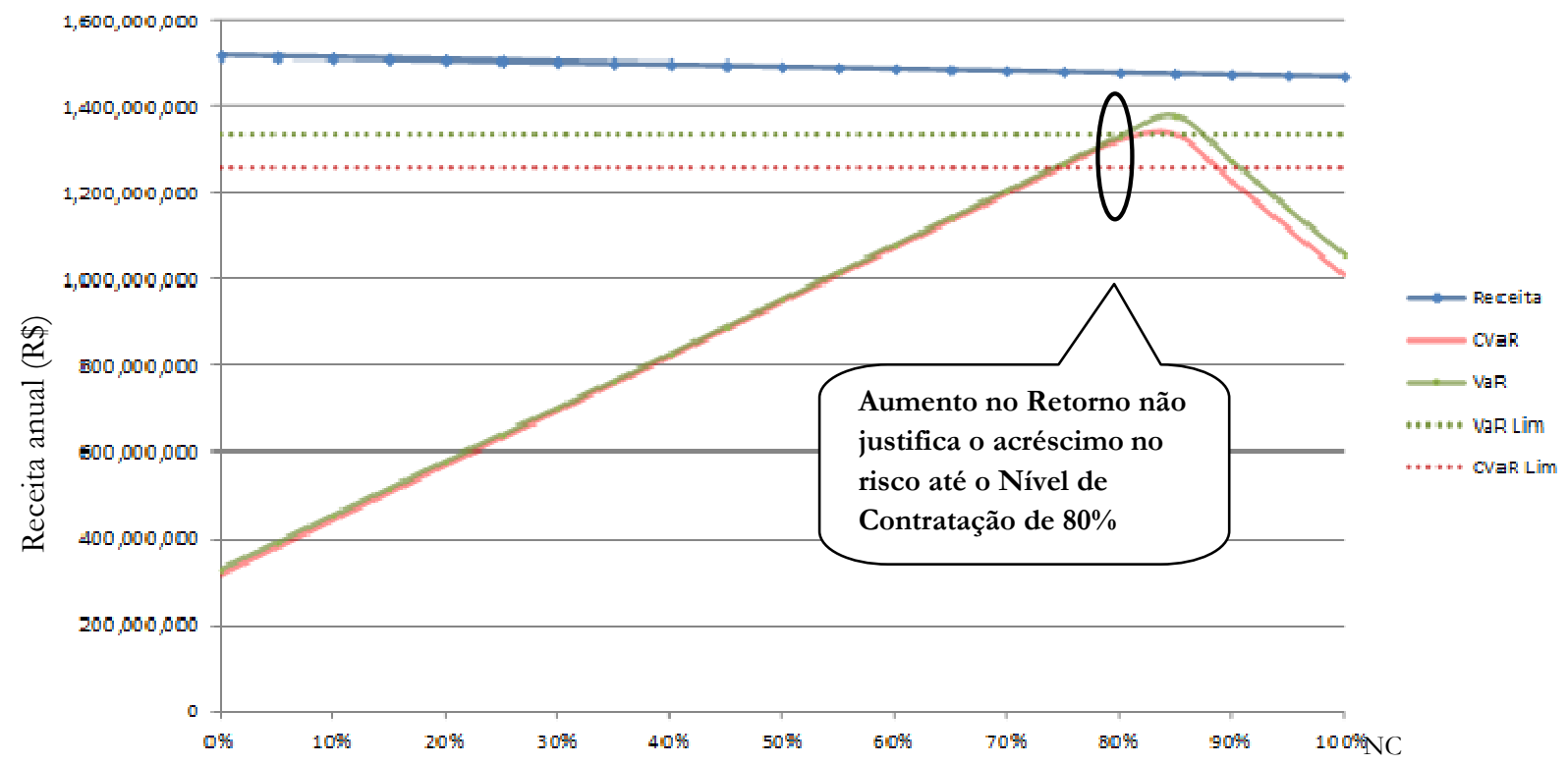

Figura 56 - Receita Esperada x Minima em condição de escassez e preço de venda R\$160/MWh (Fonte: Elaboração própria)

Índice Risco-retorno indicou um nível ótimo de contratação de $80 \%$. Isto por que à medida que se reduz o nível de contratação de 80\% (Melhor índice Risco-retorno e Risco mínimo) até 0\% (Melhor índice Risco-retorno e Risco mínimo) o acréscimo no retorno é muito inferior ao aumento no risco (redução da receita mínima). Em relação ao resultado obtido no item 10.4 pôde-se reduzir em 5\% o nível de contratação ótimo devido à expectativa de aumento de retorno frente à redução de risco.

\subsection{Simulação do Portfólio final com contratos com cláusulas de flexibilidade e sazonalidade}

Para cada nível de contratação, o volume disponível para contratação foi dividido em contratos de ano máximo $20 \mathrm{MWm}$ cada, que contemplavam atributos diversos de sazonalidade e flexibilidade. A limitação do volume de venda é uma das consequências da análise de crédito, que visa selecionar e diversificar as contrapartes, evitando concentrar grandes volumes de venda em poucos compradores. Além disso, a contratação no ACL tem como característica a venda de quantidades menores de energia.

O volume de energia atribuído a cada contrato no mês foi determinado a partir do sorteio, por meio de simulação Monte Carlo, de perfis de sazonalização combinados a uma variável aleatória 
com distribuição uniforme, cujo valor esperado é igual à energia sazonalizada e intervalo de variação definido de acordo com sua flexibilidade.

A sazonalização permite uma variação na alocação mensal do volume médio anual contratado de $-10 \% /+10 \%$, de tal forma que a soma dos volumes mensais sazonalizados seja equivalente ao volume anual contratado. A flexibilidade dos contratos candidatos foi definida em $-10 \% /+10 \%$ sobre o montante mensal sazonalizado.

Tabela 54 e Tabela 55 - Resultados do Portfólio com menor participação de energia eólica e biomassa (Risco mínimo), Preşo de venda igual a $\mathrm{R} \$ 180 / \mathrm{MWh}$ em condição de escassez e contratos de venda com atributos de sazonalidade e flexibilidade

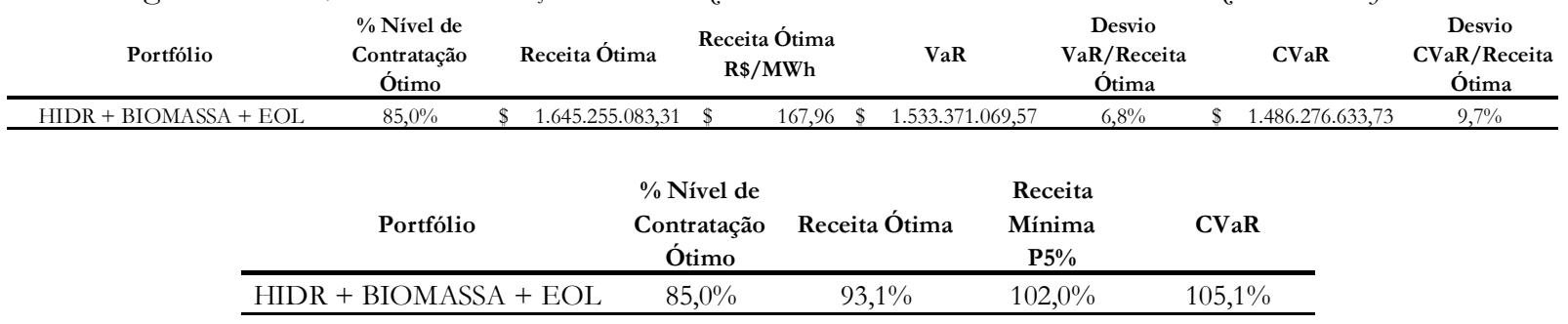

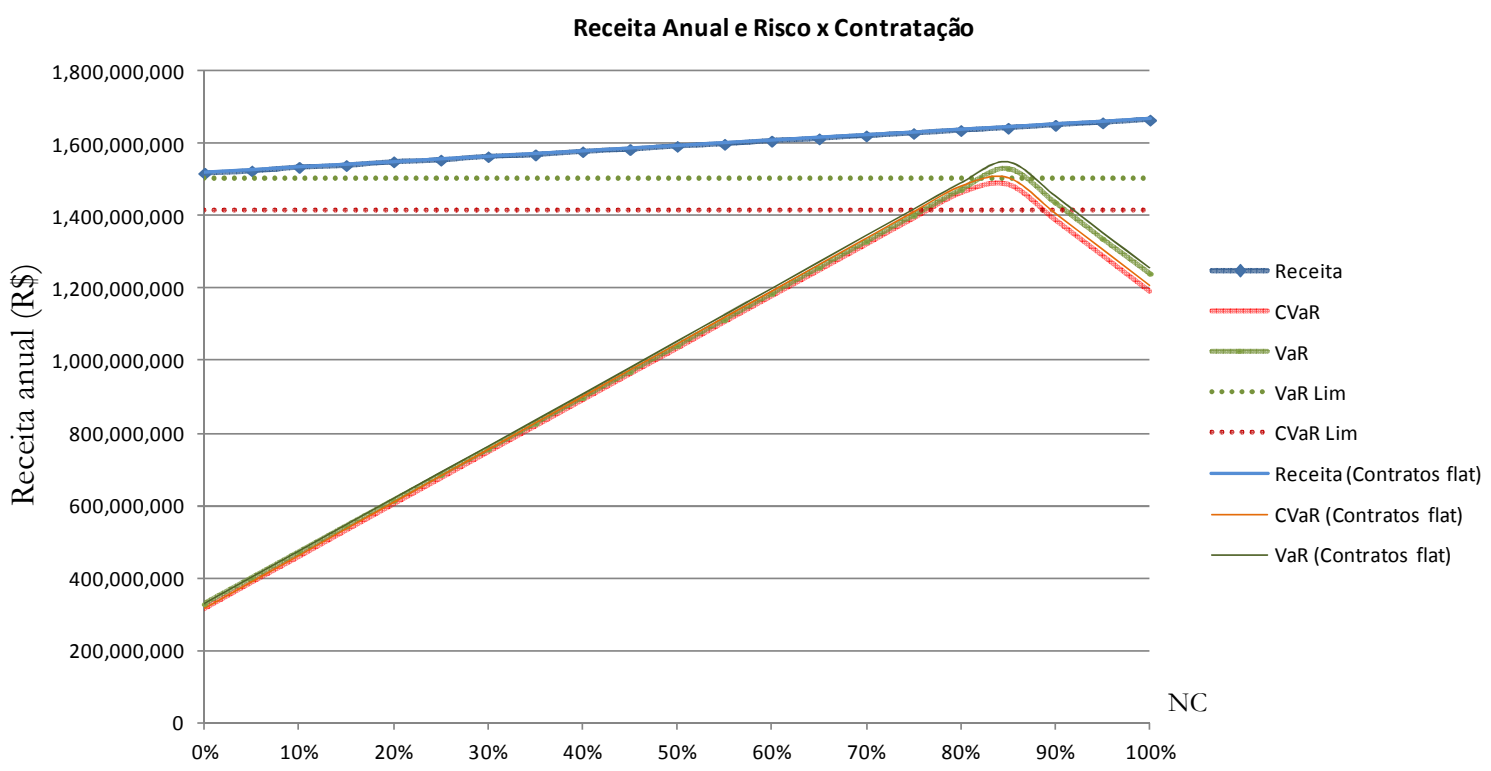

Figura 57 - Receita anual e Parâmetros de Risco $(\mathrm{R} \$) \times N C(\%)$ do portfólio com menor participação de energia eólica e biomassa (Risco minimo), Preşo de venda igual a $\mathrm{R} \$ 180 / \mathrm{MWh}$ em condição de escassez e contratos de venda com sazonalidade e flexibilidade

(Fonte: Confecção própria)

O resultado da análise com contratos de venda que contemplam sazonalidade e flexibilidade apresenta pouca variação na receita esperada e considerável incremento de risco, uma vez que foi adicionada à carteira maior variabilidade. A redução do $\mathrm{CVaR}$, quando se compara com a análise do cenário base (10.2) para o portfólio com menor participação de fontes eólica e a biomassa, 
revela uma perda potencial de $\mathrm{R} \$ 18$ milhões/ano. A mitigação deste risco é possível adicionando uma margem de $\mathrm{R} \$ 2,17 / \mathrm{MWh}$ ao preço de venda final.

A venda de energia destina-se ao consumidor final, desta forma as variações no volume do contrato de venda visam adequá-lo ao consumo do cliente. Isto exime o gerador de estratégias da contraparte com o objetivo de auferir ganhos gerando perdas ao vendedor. Isto é possível quando o comprador opta por exercer uma alta alocação e/ou máxima flexibilidade sempre que o PLD supera o preço do contrato, gerando exposição e prejuízos ao vendedor; e baixa alocação e/ou mínima flexibilidade quando o PLD está inferior ao preço contratado, reduzindo a receita do gerador.

Sendo assim, como os exercícios de sazonalidade e flexibilidade dos contratos de venda são aleatórios, é possível que tais variações sejam parcialmente anuladas ou compensadas quando se agrupa todos os contratos em um único portfólio. Por este motivo, a precificação do risco destas flexibilidades do portfólio como um todo ( $\mathrm{R} \$ 2,17 / \mathrm{MWh}$ ) é menos rigorosa do que a precificação de cada contrato individualmente $(\mathrm{R} \$ 2,87 / \mathrm{MWh}-$ sazo $10 \%+\mathrm{R} \$ 1,83 / \mathrm{MWh}-$ flex 10\%).

\subsection{Estratégia de sazonalização da Garantia Física da hidrelétrica para fins de alocação de energia no MRE no Portfólio final}

Partindo-se de uma nova estratégia de sazonalização da garantia física da usina hidrelétrica (otimizada), para fins de alocação de energia do MRE, com perfil contrário à geração média das fontes eólica e a biomassa, resultando em uma disponibilidade energética do portfólio mais constante ao longo dos meses do período da análise. Isto é feito para acentuar a complementaridade das fontes na tentativa de reduzir ainda mais a exposição quando se vende um contrato "flat" a um consumidor final. 

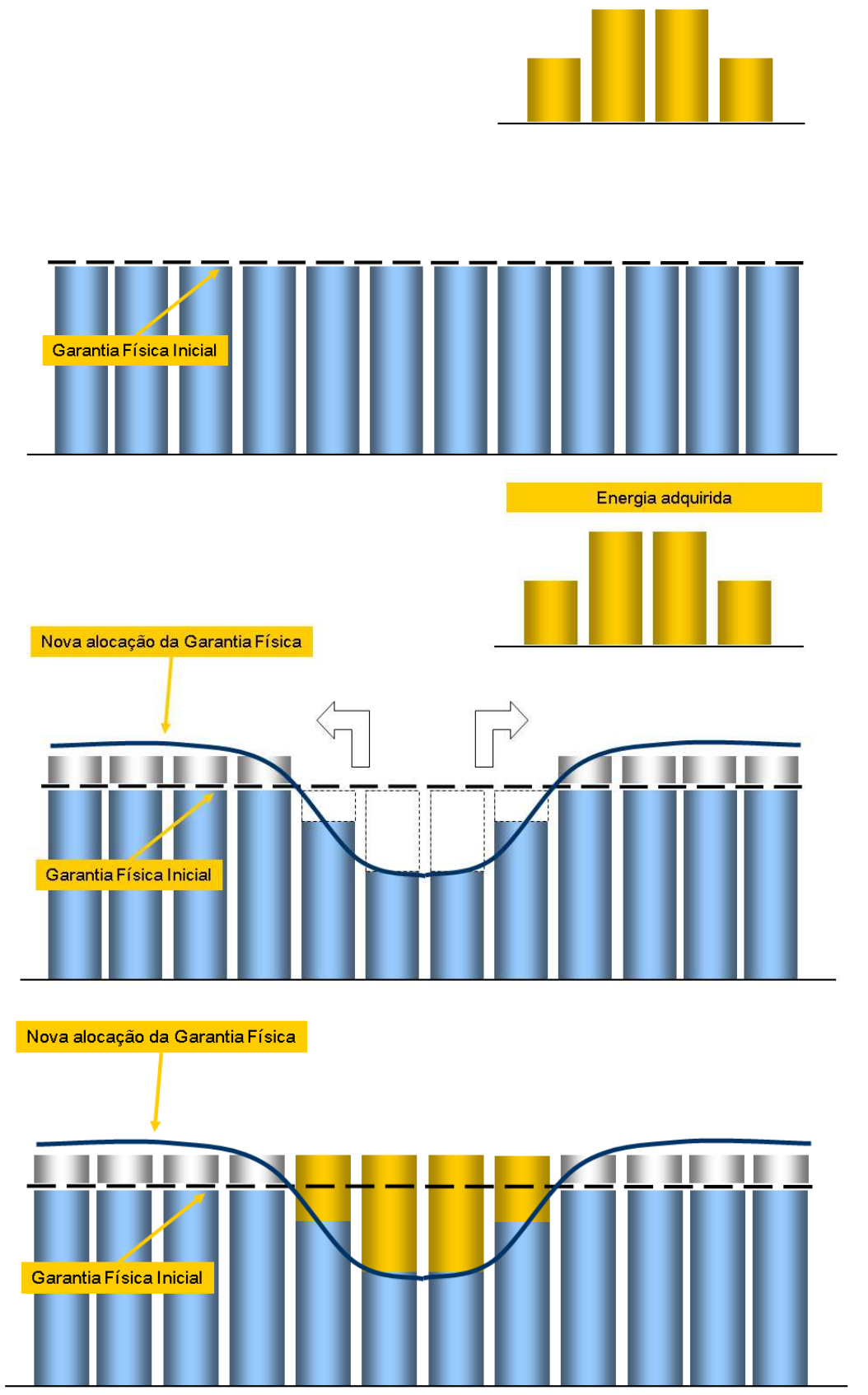

Volume disponível para venda

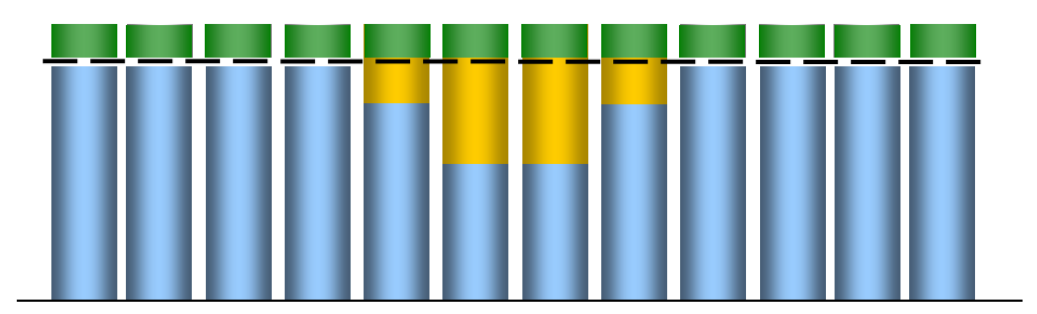

Figura 58 - Esquemático da estruturação da análise com estratégia de sazonalização da GF bidrelétrica (Fonte: Elaboraşão própria) 
Tabela 56 e Tabela 57 - Resultados do Porffólio com ajuste na sazonalização bidrelétrica e menor participação de energia eólica e biomassa (Risco mínimo) em condição de escassez e preço de venda de $\mathrm{R} \$ 180 / \mathrm{MWh}$

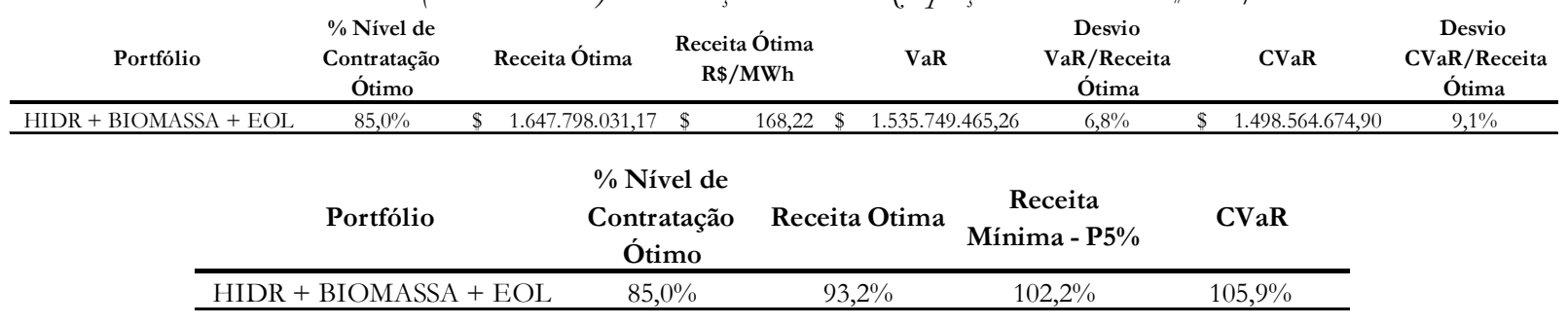

A comparação dos resultados acima com os descritos nas Tabelas 18 e 19, simulação do cenário base (condição de escassez, preço de venda de $\mathrm{R} \$ 180 / \mathrm{MWh}$, portfólio com menor participação de eólica e biomassa e sazonalização da GF hidrelétrica "flat"), indica uma melhora no retorno esperado para a estratégia de otimizar a sazonalização hidrelétrica de $\mathrm{R} \$ 1,54$ milhões. Não obstante, observou-se uma redução expressiva do CVaR, neste mesmo comparativo, equivalente a $\mathrm{R} \$ 5,8$ milhões, o que indica o aumento no risco.

O aumento no risco, a despeito do melhor retorno esperado, decorre da menor alocação de garantia física no período seco do sistema hidrológico, o que implica em menor alocação de energia e maior exposição a preços spot mais altos. Ademais a variabilidade da geração eólica não foi capturada à medida que foi considerado na estratégia de sazonalização a média de longo termo, o que não eximiu o agente gerador de exposições.

O efeito da estratégia de sazonalização será melhor aplicado no estudo discorrido a seguir. 


\section{VARIAÇÃO DO MODELO DE NEGÓCIO PROPOSTO}

Esta variação do modelo de negócio pode ser feita de maneira a utilizar a sazonalização da garantia física da empresa detentora de ativos de geração hidrelétrica para complementação da disponibilidade de energia eólica e/ou biomassa no ambiente de contratação livre, sem a mistura da energia, apenas para hedge financeiro da exposição ao mercado spot.

Este caso se aplica quando o portfólio original da empresa é de energia convencional e esta ao comprar a curva de geração de empreendimentos eólicos e/ou à biomassa tem interesse em comercializar a geração adquirida como incentivada, auferindo ganhos adicionais devido ao desconto na tarifa de uso do sistema de transporte.

A distinção dos portfólios é feita no âmbito da CCEE, onde são criados agentes convencional e incentivado, para fins de registro de lastro, geração apurada e contratos de compra e venda de energia. A compensação da modelagem proposta leva em conta o resultado financeiro do agente como um todo (convencional + incentivado).

- As exposições oriundas da diferença entre a geração da usina eólica e/ou biomassa e o montante de venda serão liquidadas no mercado spot;

- Estas exposições acarretam também penalidades por falta de lastro e perda de desconto na TUSD/TUST (somente no caso em que o empreendimento eólico ou/e a biomassa não possui Garantia Física associada);

- Como a venda de energia se dá em submercado diferente da geração, existe ainda a exposição à diferença de preços entre submercados;

- A estratégia prevê deslocamento de parte da garantia física existente do empreendedor, equivalente ao montante de exposição da usina eólica e/ou biomassa, de maneira que as exposições ao PLD sejam canceladas financeiramente;

- Assim, no período em que as fontes eólicas e/ou a biomassa possuem menor disponibilidade de seus recursos, a hidrelétrica, por meio de uma maior alocação de energia, apresenta excedente em montante equivalente ao déficit das fontes incentivadas. Por outro lado, no momento de maior disponibilidade energética da eólica e/ou biomassa, a hidrelétrica possui menor energia alocada após processamento do MRE, o 
que permite que a exposição financeira ao mercado spot seja compensada para o agente com um todo.

O risco para o empreendedor seria o impacto com ganhos ou perdas de secundária, relativo ao seu portfólio de energia hidrelétrica convencional existente e pertencente ao MRE. Uma vez que o montante de energia a ser recebido do mecanismo de realocação de energia é proporcional à garantia física sazonalizada e, portanto, a decisão de sazonalização da GF deve levar em conta este condicionante.

O montante de energia da usina hidrelétrica equivalente à GF das fontes alternativas (Tabela 17) foi sazonalizado com perfil contrário à geração média das demais fontes. Assim, no período em que as plantas eólicas e a biomassa apresentarem uma geração inferior à GF (máximo volume que pode ser disponibilizado para contratação) a alocação de energia à hidrelétrica será maior e compensará o déficit das fontes alternativas, sendo o contrário também válido.

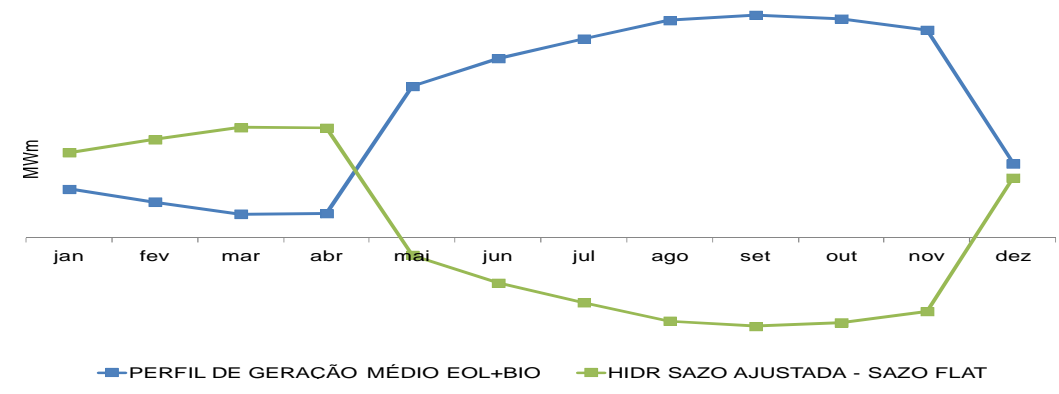

Figura 59 - Ajuste na sazonalização da usina hidrelétrica (Fonte: Confeç̧ão própria)

No entanto, tal estratégia não exime o empreendedor de possíveis exposições, uma vez que se levou em conta o perfil de geração médio da eólica e biomassa e, no caso da eólica a geração é estocástica e dependente das condições climáticas, o que faz com que sua geração apresente certa variabilidade em torno de sua média de longo termo. Além disto, nos momentos em que há déficit no MRE, principalmente devido a afluências ruins, a alocação de energia do mecanismo torna-se inferior à GF sazonalizada, gerando exposição ao conjunto.

A exemplo do item 10.10 a alteração da sazonalização da Garantia Física da hidrelétrica aumentou a expectativa de receita, no entanto, o impacto do incremento dos indicadores de risco torna-se mais significativo ao agente convencional.

A tabela a seguir expõe os resultados dos portfólios convencional e incentivado separadamente sem a realização da compensação das exposições financeiras. 
Tabela 58 - Resultados dos portfólios sem hedge financeiro

\begin{tabular}{|c|c|c|c|c|c|c|c|c|c|c|c|}
\hline Portfólio & $\begin{array}{c}\% \text { Nível de } \\
\text { Contratação Ótimo }\end{array}$ & & Receita Ótima & & $\begin{array}{l}\text { átima } \\
\text { MWh }\end{array}$ & & VaR & $\begin{array}{c}\text { Desvio } \\
\text { VaR/Receita } \\
\text { Ótima } \\
\end{array}$ & & CVaR & $\begin{array}{c}\text { Desvio } \\
\text { CVaR/Receita } \\
\text { Ótima } \\
\end{array}$ \\
\hline HIDR & & & $1.445 .869 .553,25$ & $\$$ & 165,05 & $\$$ & $1.337 .162 .104,05$ & $7,5 \%$ & $\$$ & $1.299 .069 .845,25^{\prime}$ & $10,2 \%$ \\
\hline ASSA' $\mathrm{P}_{\mathrm{y}}$ & & & 05 & & 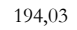 & $\$$ & 38,31 & 19 , & $\$$ & 5,46 & $23,6 \%$ \\
\hline EOL+BIOMASSA' $\mathrm{Pv}=\mathrm{R} \$ 210 / \mathrm{MWh}$ & $100,0 \%$ & $\$$ & $232.059 .941,32$ & $\$$ & 224,05 & $\$$ & $192.071 .834,81$ & $17,2 \%$ & $\$$ & $184.668 .264,16$ & $20,4 \%$ \\
\hline
\end{tabular}

A estratégia de hedge financeiro apresentou os resultados dispostos abaixo, já incorporados a cada perfil de agente. A alocação dos ganhos do hedge aos agentes foi feita de forma a anular o impacto da estratégia de sazonalização da usina hidrelétrica para o agente convencional, imputando-o ao portfólio eólica+biomassa (agente incentivado).

Tabela 59 - Resultados dos portfólios com hedge financeiro

\begin{tabular}{|c|c|c|c|c|c|c|c|c|c|c|c|}
\hline Portfólio & $\begin{array}{c}\% \text { Nível de } \\
\text { Contratação } \\
\text { Ótimo }\end{array}$ & & Receita Ótima & & $\begin{array}{l}\text { Ótima } \\
\text { MWh }\end{array}$ & & VaR & $\begin{array}{c}\text { Desvio } \\
\text { VaR/Receita } \\
\text { Ótima } \\
\end{array}$ & & CVaR & $\begin{array}{c}\text { Desvio } \\
\text { CVaR/Receita } \\
\text { Ótima }\end{array}$ \\
\hline HIDR & $82,5 \%$ & $\$$ & $1.444 .326 .836,09$ & $\$$ & 164,88 & $\$$ & $1.348 .330 .512,35$ & $6,6 \%$ & $\$$ & $1.304 .658 .681,17$ & $9,7 \%$ \\
\hline EOL+BIOMASSA' $\mathrm{Pv}=\mathrm{R} \$ 180 / \mathrm{MWh}$ & $100,0 \%$ & $\$$ & 202.513.040,21 & $\$$ & 195,52 & $\$$ & $184.540 .124,37$ & $8,9 \%$ & $\$$ & $170.686 .348,07$ & $15,7 \%$ \\
\hline EOL + BIOMASSA' $P_{v}=R \$ 210 / M W h$ & $100,0 \%$ & $\$$ & $233.602 .658,48$ & $\$$ & 225,54 & $\$$ & $215.612 .716,56$ & $7,7 \%$ & $\$$ & $201.764 .615,62$ & $13,6 \%$ \\
\hline
\end{tabular}

Reduziu-se consideravelmente o risco do portfólio eólica + biomassa, observado nos menores desvios de VaR e CVaR em relação à Receita expostos na Tabela 58 quando comparados aos da Tabela 57. Além do aumento na receita esperada para o agente incentivado e redução no risco incorrido ao agente convencional.

É possível ainda auferir ganhos adicionais de receita trabalhando-se com o preço de venda de energia incentivada de $\mathrm{R} \$ 210 / \mathrm{MWh}^{25}$. Este ganho se traduz também em uma redução de risco.

É importante mencionar que a venda de energia incentivada está sujeita a penalização pela perda de desconto na tarifa de transporte sempre que a geração for menor que a venda no mês.

\section{Sensibilidade Preço de Venda da Energia}

Quando foi feita a sensibilidade em relação ao preço de venda na condição de escassez, considerando-o igual a $\mathrm{R} \$ 160 / \mathrm{MWh}$, no modelo de negócios anterior, a carteira formada exclusivamente pelas plantas eólica e a biomassa não atendeu ao critério de risco imposto à Receita Mínima (Tabela 29).

25 A venda da energia como incentivada é possível quando se adquire energia de um conjunto de usinas caracterizadas como fontes incentivadas, com potência instalada de até $30 \mathrm{MW}$ cada uma. 
Vejamos o comportamento da receita e parâmetros de risco quando analisamos as mesmas fontes e preço de venda submetidos à variação do modelo de negócio proposta.

Tabela 60 e Tabela 61 - Resultados dos portfólios com hedge financeiro e sensibilidade de preşo de venda

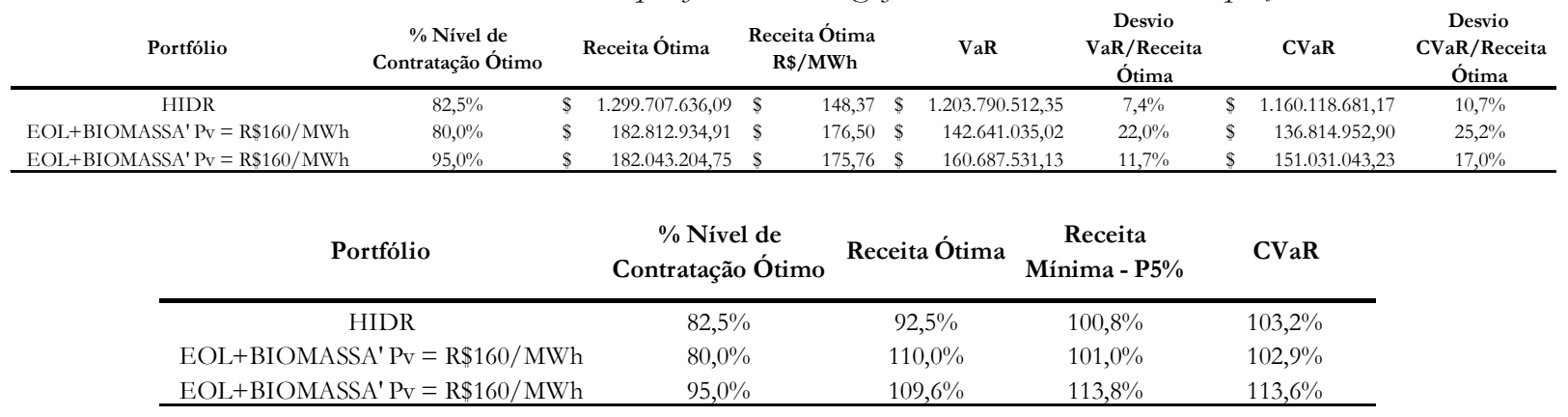

Como o preço de venda de $\mathrm{R} \$ 160 / \mathrm{MWh}$ é inferior ao valor médio do PLD no período da análise, sob a ótica de ganho em receita é interessante ficar mais descontratado e desfrutar da possibilidade de preços maiores no mercado de curto prazo, o que pode ser observado comparando-se a receita da carteira eólica+biomassa nos níveis de contratação de $80 \%$ e $95 \%$. A contratação de $95 \%$ foi resultado da análise do estudo de caso anterior.

Com esta nova estratégia foi possível viabilizar o portfólio de fontes alternativas, uma vez que os ganhos na receita esperada e no CVaR são maiores tanto para o nível de contratação ótimo (80\%) quanto para o nível de contratação equivalente a 95\%. O acréscimo em receita para o NC 80\% tem a contrapartida de acréscimo no risco, respeitando as exigências dos limites estabelecidos. 


\section{CONCLUSÃO}

O Setor Elétrico Brasileiro vem passando por intensas modificações de cunho regulatório, estrutural e político. Dada sua relevância como sendo um dos pilares da infraestrutura, o setor de energia elétrica tem respondido a essas mudanças de forma rápida e eficiente, visto que não é mais possível retroceder aos patamares de uma estrutura verticalizada.

Um dos pontos fundamentais que leva à necessidade de discussão de medidas de mitigação de risco é o novo cenário de preços de curto prazo mais elevado e com maior volatilidade. Isso tem sido verificado desde 2012 e espera-se que seja mantido pelos próximos anos em virtude de expectativa de cenários hidrológicos menos favoráveis, associados à expansão da oferta por fontes intermitentes de geração, redução de regularização do sistema e à introdução do CVAR no modelo de despacho que é a base para a formação do preço.

A complementaridade entre fontes pode ser usada como um mecanismo de proteção para os agentes de mercado, empregando a sinergia existente entre as usinas com perfis de geração complementares para obter maior independência a fatores externos, como mudanças regulatórias e volatilidade de preços de curto prazo, sem submeter a receita esperada a riscos maiores do que aqueles aceitos pelo agente ${ }^{26}$.

Em se tratando de energia renovável não convencional, agentes ou grupos de agentes com portfólios compostos por duas ou mais dessas fontes têm se tornado uma realidade cada vez mais presente no mercado. Essa característica traz um benefício que pode ser explorado por esses agentes, representando uma vantagem econômica.

Dentre os resultados das simulações feitas no estudo de caso para o presente trabalho, pode ser destacado que a viabilização da operação comercial de uma PCH quando analisada isoladamente só é possível se a mesma pertencer ao MRE. A estratégia visando à maximização do retorno (neutra ao risco) é obtida com um portfólio apenas de usina com cogeração a biomassa.

\footnotetext{
${ }^{26}$ A térmica convencional opera de forma complementar à hidrelétrica, uma vez que o despacho térmico desloca a geração hidrelétrica, culminando com a exposição da fonte hídrica no mercado spot a preços elevados, enquanto a fonte térmica se apropria dos ganhos de receita advindos de liquidar sua geração ao PLD, que supera seu CVU (despacho na ordem de mérito econômico). Como o foco do trabalho é a comercialização no ACL e dada a difícil viabilização de projetos de térmicas convencionais nesse ambiente, o trabalho não contemplou essa fonte na análise de complementaridade. Tal análise é pertinente para plantas térmicas já amortizadas e descontratadas.
} 
Isto devido à relação vantajosa que existe entre o perfil de geração da usina de biomassa e os valores esperados de preço spot. Entretanto, o risco incorrido pelo empreendedor ao apostar nesta configuração inviabiliza esta opção.

A composição do portfólio de um comercializador segundo o critério de risco mínimo de Markowitz resultou em uma mistura entre as fontes de geração hidrelétrica e eólica, pois a correlação dos retornos de comercialização de geração da pequena central hidrelétrica e da usina eólica é a mais negativa dentre as combinações de fontes de geração. O que significa que a complementaridade das duas fontes é mais acentuada, implicando em menor exposição e, consequentemente, em menor risco.

Foi possível observar o "hedge" resultante da complementaridade de perfil de geração das fontes hidrelétrica, eólica e de cogeração a biomassa e os benefícios trazidos pela diversificação da carteira.

Outro ponto de destaque é o comportamento das curvas de receita para os casos de preço de contrato maior e menor que o PLD médio esperado do horizonte da análise. Ficou evidente que nos casos onde o preço de venda é menor que o PLD médio, o modelo tenderia a deixar toda a placa descontratada, pois os ganhos a longo prazo seriam maiores. No entanto têm-se situações de receitas muito reduzidas em longos períodos em que o preço spot é baixo (períodos hidrológicos favoráveis). Por isso, ao ser inserida uma limitação do risco, o modelo indica a necessidade de um percentual mínimo de alocação que garanta o atendimento a tais critérios e retorne a maior receita possível. $\mathrm{Na}$ situação de preço de venda superior ao PLD Médio, é vantajoso aumentar a alocação de energia ao contrato, pois é o melhor retorno no longo prazo, com baixo risco de perda de receita.

A principal ferramenta de gestão de risco de energia utilizada no mercado brasileiro é a realização de contratos "por quantidade". Apesar disso, os contratos introduzem outros fatores de risco, tais como flexibilidade, sazonalidade e oriundo da venda de energia em subsistema diferente do local de geração. Como o exercício de sazonalidade e flexibilidade dos contratos de venda são considerados aleatórios em função do comportamento desconhecido do consumo, é possível que tais variações sejam parcialmente anuladas ou compensadas quando se agrupa todos os contratos em um único portfólio. Por este motivo, a precificação deste risco no portfólio como um todo é menos rigorosa do que a precificação de cada contrato individualmente. 
No modelo de negócio proposto, com a aquisição da "curva de geração" da eólica e/ou biomassa, incorporando a sua Garantia Física existente e negociando a venda do total de lastro disponível, o gerador assume todos os riscos de mercado na comercialização e, por consequência, mitiga completamente os riscos de mercado do empreendedor da eólica e/ou cogeração. Caso a planta eólica e/ou biomassa sozinha não atinja a exigência de risco, o diferencial de preço entre compra e venda de sua geração tem função de alavancar a eólica e/ou biomassa ao nível de risco fixado. Com montantes mais reduzidos de compra de energia destas fontes, a sinergia é suficiente para por si só gerar essa alavancagem e se poderia pagar um preço de compra superior ao preço de venda.

À medida que se aumenta a participação das fontes eólica e a biomassa no portfólio pode-se alavancar o \% de contratação, mas em contrapartida há o acréscimo no risco.

O afrouxamento do critério de cálculo da garantia física da usina eólica (P90\% para P50\%) inviabilizou a fonte individualmente ou mesmo combinada com a usina de cogeração a biomassa em função da violação das exigências impostas (risco). A estratégia para o portfólio com as três fontes analisadas foi reduzir o nível de contratação ou o preço de aquisição da curva de geração das fontes alternativas para alavancar esta opção ao nível de risco requerido.

A decisão sobre a quantidade de energia disponibilizada para contratação, segundo um critério de aversão ao risco, não depende do valor esperado da receita no conjunto de cenários possíveis como é feito na estratégia neutra ao risco, mas sim do que acontece com a mesma nos piores cenários vislumbrados. Assim a estratégia avessa ao risco procura reduzir significativamente a exposição do gerador ao risco hidrológico e de baixa geração das fontes eólicas e a biomassa, evitando que ele tenha que comprar energia no mercado spot em cenários de geração desfavoráveis que, em geral, apresentam PLDs altos.

Condições de abastecimento do sistema mais favoráveis implicam em ganhos de receita média menores, em contrapartida os riscos de exposição a que as fontes estão submetidas também são significativamente inferiores, o que permite elevar o nível de contratação das carteiras garantindo uma receita fixa advinda da contratação maior, isto em razão do preço de venda considerado ser superior ao preço spot médio do horizonte da análise. Em razão disso, o preço de aquisição da curva de geração eólica e de cogeração reduz. 
Sensibilidades em relação às restrições de risco visam identificar se pequenas variações sobre o risco ao qual se está exposto podem representar ganhos em termos de receita que se justifiquem decisões mais ou menos conservadoras. À medida que os critérios de risco que subsidiam a decisão tornam-se menos rigorosos tem-se a possibilidade que auferir maiores ganhos em média, pois a maximização da receita esperada passa a ter mais peso na estratégia de contratação, com isto a mitigação de risco por meio do nível de contratação ótimo e da aquisição da curva de geração de fontes complementares deixa de apresentar efeitos tão significativos. Uma consequência do afrouxamento dos limites de risco é o aumento dos desvios entre VaR e CVaR em relação à Receita esperada, o que representa uma maior dispersão da distribuição dos resultados de receita e a possibilidade de receitas muito reduzidas nos piores cenários.

O aumento no retorno não justifica o aumento no risco quando se altera de uma estratégia de minimização de risco para maximização de retorno. O critério de maximização do CVaR apresenta um resultado consistente e independente se o preço de venda é superior ou inferior ao preço médio no spot.

O resultado da análise com contratos de venda que contemplam sazonalidade e flexibilidade apresenta pouca variação na receita esperada e considerável incremento de risco, uma vez que foi adicionada à carteira maior variabilidade. A redução do $C V a R$ revela uma perda potencial de $\mathrm{R} \$$ 18 milhões/ano. A mitigação deste risco é possível adicionando uma margem de R \$2,17/MWh ao preço de venda final.

A estratégia de sazonalização da garantia física da usina hidrelétrica, para fins de alocação de energia do MRE, com perfil contrário à geração média das fontes eólica e a biomassa, resulta em uma disponibilidade energética do portfólio mais constante ao longo dos meses do período da análise. O aumento no risco a despeito do melhor retorno esperado decorre da menor alocação de garantia física no período seco do sistema hidrológico, o que implica em menor recebimento de energia e maior exposição a preços spot mais altos. Ademais a variabilidade da geração eólica não foi capturada à medida que foi considerado na estratégia de sazonalização a média de longo termo, o que não eximiu o agente gerador de exposições. A estratégia de utilização da complementaridade apenas para hedge financeiro reduz consideravelmente o risco do portfólio eólica + biomassa de forma a assumir um nível de contratação que traga maior retorno. É 
possível ainda auferir ganhos adicionais de receita comercializando a energia das fontes alternativas como incentivada.

Durante a confecção deste trabalho, algumas limitações foram identificadas, as quais não prejudicaram o alcance do objetivo final, porém, caso fossem ultrapassadas, poderiam indicar resultados ainda mais aderentes à realidade do mercado. Dentre essas simplificações, pode ser citada a geração da usina a Biomassa, que não levou em consideração as típicas paradas não programadas, bem como atrasos e perda na qualidade do bagaço devido a fatores climáticos, em especial chuva (excesso ou falta).

A conclusão da pesquisa foi a análise estruturada dos riscos e a comparação da atratividade do mercado livre frente aos riscos e exposições que os geradores, que produzem energia de forma inconstante ao longo do ano, estão submetidos.

De acordo com os resultados obtidos, foram propostos dispositivos de cunho financeiro e/ou regulatório, para adequada mitigação dos riscos de mercado evidenciados no decorrer do trabalho. 


\section{REFERÊNCIAS BIBLIOGRÁFICAS}

[1] RAMOS, D. S., "Reestruturação do Setor Elétrico Brasileiro. Parte III: Principais Institutos do Modelo RE-SEB," Material utilizado na disciplina Formação de Preços e Comercialização de Energia no Novo Ambiente do Setor em disciplina de pós-graduação da Escola Politécnica da USP, São Paulo - SP, 2008.

[2] OPERADOR NACIONAL DO SISTEMA ELÉTRICO (ONS). Plano da Operação Energética 2014-2018 (PEN 2014). Rio de Janeiro : (s.n), 2013. p. 141 p.

[3] CAMARGO, L.A.S., et al. A Business Model to Incentivize Hydro Companies Inversions in Wind and Biomass Power Plants. 4th International Youth Conference on Energy 2013. 2013.

[4] PIERONI, F. P., "Impacto das Mudanças no Marco Regulatório do Setor Elétrico Brasileiro nas Estratégias de Investimento em Autoprodução," Dissertação de Mestrado, Universidade de São Paulo, São Paulo, SP, 2005.

[5] Câmara de Comercialização de Energia Elétrica. Regras de Comercialização. Disponível em: http://www.ccee.org.br

[6] CÂMARA DE COMERCIALIZAÇÃO DE ENERGIA ELÉTRICA (CCEE); OPERADOR NACIONAL DO SISTEMA ELÉTRICO (ONS). O SIN e os modelos para o Planejamento da Operação Energética. 2011.

[7] BRASIL. AGÊNCIA NACIONAL DE ENERGIA ELÉTRICA (ANEEL). Resolução no 281. Estabelece as condições gerais de contratação do acesso, compreendendo o uso e a conexão, aos sistemas de transmissão de energia elétrica. 1999.

[8] BRASIL. AGÊNCIA NACIONAL DE ENERGIA ELÉTRICA (ANEEL). Resolução 219. Dá nova redação ao art. 22 da Resolução no 281, de 1o de outubro de 1999, com prazo para republicação integral. 2003.

[9] BRASIL. AGÊNCIA NACIONAL DE ENERGIA ELÉTRICA (ANEEL). Altera a redação dos arts. $1^{\circ}$ e $3^{\circ}$ da Resolução Normativa n ${ }^{\circ} 77$, de 18 de agosto de 2004. Resolução Normativa 271. 2007 estabelece os procedimentos vinculados à redução das tarifas de uso dos sistemas elétricos de transmissão e de distribuição, para empreendimentos hidrelétricos, caracterizados como Pequena Central Hidrelétrica, e aqueles com fonte solar, eólica, biomassa ou cogeração qualificada, com potência instalada menor ou igual a $30.000 \mathrm{~kW}$.

[10] BRASIL. AGÊNCIA NACIONAL DE ENERGIA ELÉTRICA (ANEEL). Resolução nº 652. Estabelece os critérios para o enquadramento de aproveitamento hidrelétrico na condição de Pequena Central Hidrelétrica (PCH). 2003.

[11] RAMOS, D.S., et al. Avaliação do Impacto da participação da Geração Eólica no MRE Contemplando Reconstituição de Séries Temporais de Velocidade de Vento. Plan4 Engenharia, GEPEA, MRFS, Lab Plan. 2013. Projeto de P\&D.

[12] BRASIL. CONSELHO NACIONAL DE POLÍTICA ENERGÉTICA (CNPE). Resolução $n^{\circ}$ 1. Define o critério geral de garantia de suprimento aplicável aos estudos de expansão da 
oferta e do planejamento da operação do sistema elétrico interligado, bem como ao cálculo das garantias físicas... Brasília : (s.n.), 2004.

[13] LAGE, E. S. e PROCESSI, L. D. Panorama do setor de energia eólica. Revista do BNDES. 6 de 2013. pp. 183-206. 39.

[14] ASSOSSIAÇÃO BRASILEIRA DE ENERGIA EÓLICA (ABEEÓLICA). Notícias. MME ampliará benefícios do Reidi ao mercado livre. ABEEÓLICA. (Online) 10 de 9 de 2013. (Citado em: 10 de 12 de 2013.) http://www.portalabeeolica.org.br/index.php/noticias/1020-mmeampliará-benefíciosdo- reidi-ao-mercado-livre.html.

[15] A.S. CHUANG, C. SCHWAEGERL. Ancillary Services for Renewable Integration. Integration of Wide-Scale Renewable Resources Into the Power Delivery System, 2009 CIGRE/IEEE PES Joint Symposium. 2009, p. 1 p.

[16] SUSTERAS, G.L., et al. Attracting Wind Generators to the Wholesale Market by Mitigating Individual Exposure to Intermittent Outputs: an Adaptation of the Brazilian Experience with Hydro Generation. $8^{\circ}$ International Conference on the European Energy Market. 2011.

[17] RAMOS, D.S., GUARNIER, E. e WITZLER, L.T. Using the seasonal diversity between renewable energy sources to mitigate the effects of Wind generation uncertainties. Transmission and Distribution: Latin America Conference and Exposition, Sixth IEEE/PES. 2012, pp. 1-7 p.

[18] RAMOS, D.S., et al. Minimizing Market Risk by Trading Hydro-Wind Portfolio: A Complementary Approach. 10th International Conference on the European Energy Market. Stockholm : s.n., 2013.

[19] DIAS, NATÁLIA VANTON. Estratégias de Comercialização de Energia para um Portfólio de Usinas: Análise da Complementaridade Energética e Mecanismo de Hedge. Projeto de Formatura, Escola Politécnica da Universidade de São Paulo (USP). Orientador: Prof. Dr. Dorel Soares Ramos. São Paulo : s.n., 2007.

[20] MARINHO, RAONI RUGAI. Estudo de alternativas de comercialização para alavancar a viabilidade econômica de Usinas Eólicas no Parque Gerador Brasileiro. Projeto de Formatura, Escola Politécnica da Universidade de São Paulo (USP). Orientador: Prof. Dr. Dorel Soares Ramos. São Paulo : s.n., 2011.

[21] REDA, ALEXANDRE GUNFINKEL. Complementação energética entre pequenas centrais hidrelétricas e usinas eólicas considerando a inserção de incertezas para cenários futuros de geração. Projeto de Formatura, Escola Politécnica da Universidade de São Paulo (USP). Orientador: Prof. Dr. Dorel Soares Ramos. São Paulo : s.n., 2011. p. 110 p.

[22] GUARNIER, E., CAMARGO, L.A.S. e RAMOS, D. S. Incorporando os efeitos da complementaridade Hidro-Eólica na formação do Portfólio de Empresas Geradoras de Energia Elétrica. XII Symposium of Specialists in Electric Operational and Expansion Planning. Rio de Janeiro : s.n., 2012.

[23] RAMOS, D. S., et al. Análise Estruturada de Portfólio de Unidades de Geração de Características Sazonal e Complementar com o Suporte de Algoritmos Genéticos. Congresso de Inovação Tecnológica em Energia Elétrica - CITENEL,2013. São Paulo : s.n., 2013. 
[24] RAMOS, D.S., et al. Análise Estruturada de Portfólio de Unidades de Geração de Características Sazonal e Complementar com o Suporte de Algoritmos Genéticos. Congresso de Inovação Tecnológica em Energia Elétrica - CITENEL,2013. São Paulo : s.n., 2013.

[25] STREET, A.; BARROSO L. A.; FLACH B. PEREIRA; M. V. GRANVILLE S. 2009. "Risk Constrained Portfolio Selection of Renewable Sources in Hydrothermal Electricity Markets". IEEE Transactions on Power Systems, Aug. 2009, Vol. 24, no. 3, pp. 1136-1144.

[26] RALSTON, FRANCISCO, et al. Risk Constrained Contracting Strategies of Renewable Portfolios. Energy Market (EEM), 2010 7th International Conference on the European. Madrid : IEEE, 2010.

[27] STREET, ALEXANDRE, et al. Sharing Quotas of a Renewable Energy Hedge. Power Tech, 2011 IEEE Trondheim. Trondheim : s.n., 2011. pp. 1-6 p.

[28] FONSECA, F. R. “Estratégias de Sazonalização da Garantia Física de PCH’s em Portfólios de PCH E Biomassa”. Rio de Janeiro. 2009. 174p. Dissertação de Mestrado (Orientador: A.

Veiga e S. Granville) - Dep. de Eng. Elétrica, Pontifícia Universidade Católica do Rio de Janeiro.

[29] DIAS, N.V. Estratégias de Comercialização de Energia para um Portfólio de Usinas: Análise da Complementaridade Energética e Mecanismo de Hedge. Projeto de Formatura, Escola Politécnica da Universidade de São Paulo (USP). Orientador: Prof. Dr. Dorel Soares Ramos. São Paulo : s.n., 2007.

[30] MARINHO, R.R. Estudo de alternativas de comercialização para alavancar a viabilidade econômica de Usinas Eólicas no Parque Gerador Brasileiro. Projeto de Formatura, Escola Politécnica da Universidade de São Paulo (USP). Orientador: Prof. Dr. Dorel Soares Ramos. São Paulo : s.n., 2011.

[31] BORO, S.R.. Análise da complementaridade entre fontes renováveis não convencionais como mecanismo de proteção para mitigação de riscos de mercado. Dissertação (Mestrado) Escola Politécnica, Universidade de São Paulo, São Paulo 2014. São Paulo : s.n., 2014.

[32] TAKEMOTO, K.A. Energia Incentivada: uma análise integrada dos aspectos regulatórios, de comercialização e de sustentabilidade. Disertação (Mestrado) - Escola Politécnica, Universidade de São Paulo, São Paulo 2012. São Paulo : s.n., 2012. p. 164 p.

[33] BARROSO, L.A.; STREET, A.; GRANVILLE, S.; PEREIRA, M.V.; “Offering Strategies and Simulation of Multi Item Dynamic Auctions of Energy Contracts". IEEE Transactions on Power System, vol.26, no.4, pp. 1917-1928, Nov. 2011.

[34] SECURATO, J. R. 1996b "Decisões financeiras em condições de risco". 244p, p191-230, Editora Atlas S. A. São Paulo, 1996.

[35] Jorion Philippe, Value At Risk - A Nova Fonte de Referência para a Gestão do Risco Financeiro - $2^{\mathrm{a}} \mathrm{Ed}$.

[36] OJANEN, O. J., 2002. "Comparative analysis of Risk Management Strategies for Electricity Retailers". Dissertação de Mestrado. Department of Engineering Physics and Mathematics, University of Technology, Helsink, Finlândia. 
[37] LIU, M. WU, F. NI Y. 2006. “A survey on Risk Management in Electricity Markets”, IEEE Power Engineering Society General Meeting”. Montreal, Canada.

[38] MAYO, R. 2009. Derivativos de Eletricidade \& Gerenciamento de Risco. Rio de Janeiro: Ed. Synergia.

[39] STREET A. "Equivalente Certo e Medidas de Risco em decisões de Comercialização de Energia Elétrica". Rio de Janeiro. 2008. 174p. Tese de Doutorado (Orientador: A. L. Veiga Filho) - Dep. de Eng. Elétrica, Pontifícia Universidade Católica do Rio de Janeiro.

[40] ROCKAFELLAR, R. T. e URYASEV, S. Optimization of conditional value at risk. The Journal of Risk. 2000, pp. 21-41.

[41] RAGSDALE, CLIFF T. Modelagem e Análise de Decisão. São Paulo : Cengage Learning, 2011.

[42] KROZER, YORAM. Cost and benefit of renewable energy in the European Union. Elsevier Renewable Energy. Ed. 50, 2013, pp. 68-73.

[43] YANG, XIA et. al. A Comprehensive Review on the Development of Sustainable Energy Strategy and Implementation in China. IEEE Transactions On Sustainable Energy. Ed. 2, 2010, Vol. Vol. 1.

[44] MUÑOZ J. I. SÁNCHEZ A. A. CONTRERAS J. BERNAL-AGUSTÍN J. L. 2009. "Optimal investment portfolio in renewable energy: The Spanish case". Energy Policy. Vol. 37, pp. 5273-5284.

[45] BRASIL. Agência Nacional de Energia Elétrica. Legislação disponível em: http://www.aneel.gov.br/

[46] BRASIL. Ministério de Minas e Energia. Legislação.

Disponível em: http://www.mme.gov.br/mme/menu/legislacao.html

[47] BRASIL. Lei no 10.848 , de 15 de março de 2004. Dispõe sobre a comercialização de energia elétrica, altera as leis n 5.655, de 20 de maio de 1971, 8.631, de 4 de março de 1993, 9.074, de 7 de julho de 1995, 9.427, de 26 de dezembro de 1996, 9.478, de 6 de agosto de 1997, 9.648, de 27 de maio de 1998, 9.991, de 24 de julho de 2000, 10.438, de 26 de abril de 2002, e dá outras providências. Diário Oficial (da) República Federativa do Brasil, Brasília, DF, 16 mar. 2004. Disponível em: http://www.planalto.gov.br/ccivil 03/ Ato2004-2006/2004/Lei/L10.848.htm

[48] BRASIL. Decreto $n^{\circ}$ 5.163, de 30 de julho de 2004. Regulamenta a comercialização de energia elétrica, o processo de outorga de concessões e de autorizações de geração de energia elétrica, e dá outras providências. Disponível em: http://www.planalto.gov.br/ccivil 03/ Ato2004-2006/2004/Decreto/D5163.htm

[49] Empresa de Pesquisa Energética. Estatística e análise do mercado de energia elétrica. Disponível em: http://www.epe.gov.br/BoletimMensal/Forms/EPEBoletimMensal.aspx

[50] EMPRESA DE PESQUISA ENERGÉTICA (EPE). Plano Decenal de Expansão de Energia 2022. Brasília : (s.n.), 2013. p. 410 p 
[51] AMERICAN WIND ENERGY ASSOCIATION (AWEA). 20\% Wind Energy by 2030: Wind, Backup Power and Emissions. (Online) American Wind Energy Association (AWEA). (Citado em: 12 de novembro de 2012.)

http://www.awea.org/learnabout/publications/upload/Backup Power.pdf.

[52] CENTRAIS ELÉTRICAS BRASILEIRAS S.A. (ELETROBRAS). Programas e Fundos Setoriais: Proinfa. (Online) ELETROBRAS. (Citado em: 10 de novembro de 2012.) http://www.eletrobras.com/elb/data/Pages/LUMISABB61D26PTBRIE.htm.

[53] PIMENTA, M.C. e REZENDE, P.F.V.S.. A evolução do Proinfa: acompanhamento da implantação das PCHs. (Itajubá - MG) : (s.n.), Centro Nacional de Referência em Pequenas Centrais Hidrelétricas (CERPCH), 18 de maio de 2011.

[54] KALTSCHMITT, M.; STREICHER, W.; e WIESE, A. Renewable Energy -Technology, Economics and Environment. Frankfurt : Ed. Springer, 2007.

[55] BEZERRA, B.; MOCARQUER, S.; BARROSO, L.; RUDNICK, H. Energy Challenges in Brazil and Chile. (ed.) (s.n). Piscataway, New Jersey : IEEE Power and Energy Society, 2012. Vol. 10. 1540-7977.

[56] SILVA, E.F. Principais Condicionantes das Alterações no Modelo de Comercialização e Energia Elétrica: Retrospectiva e Análise Crítica. Disertação (Mestrado) - Escola Politécnica, Universidade de São Paulo, São Paulo 2008. São Paulo : s.n., 2008. p. 215 p.

[57] CAMARGO, I.M.T. e ALMEIDA, L.H.B. A Contratação de Energia de Reserva no Atual Modelo do Setor Elétrico Brasileiro: da Teoria à Prática. (Itajubá): Sociedade Brasileira de Planejamento Energético, $2^{\circ}$ Semestre 2009. Vol. 15, № 2.

[58] BANCO NACIONAL DO DESENVOLVIMENTO (BNDES). Notícias. BNDES aprova financiamento de R $\$ 255$ milhões para 3 PCHS. BNDES. (Online) 29 de 8 de 2007. (Citado em: 10 de 12 de 2013.) http://www.bndes.gov.br/SiteBNDES/bndes/bndes_pt/Institucional/Sala_de_Imprensa/Noti cias/2007/20070829_not195_07.html.

[59] BANCO NACIONAL DO DESENVOLVIMENTO (BNDES). Notícias. BNDES financia oito parques eólicos no valor de R\$ 445,7 milhões no RS. BNDES. (Online) 28 de 7 de 2011. (Citado em: 10 de 12 de http://www.bndes.gov.br/SiteBNDES/bndes/bndes_pt/Institucional/Sala_de_Imprensa/Noti cias/2011/todas/20110728_eolica.html.

[60] EMPRESA DE PESQUISA ENERGÉTICA (EPE). Metodologia de Cálculo da Garantia Física das Usinas. (Online) 02 de junho de 2008. (Citado em: 08 de dezembro de 2013.) http://epe.gov.br/geracao/Documents/Estudos 26/NT\%20\%20metodologia $\% 20 \mathrm{de} \% 20 \mathrm{c} \% \mathrm{C} 3$ $\%$ A1lculo $\% 20 \mathrm{da} \% 20 \mathrm{GF} \% 20$ para $\% 20$ novas $\% 20$ usinas.pdf.

[61] CÂMARA DE COMERCIALIZAÇÃO DE ENERGIA ELÉTRICA (CCEE); OPERADOR NACIONAL DO SISTEMA ELÉTRICO (ONS). Guia prático de utilização do Modelo Newave - versão 15. 2009.

[62] MME, "O Novo Modelo do Setor Elétrico," Ministério de Minas e Energia, Brasília, julho de 2003. 


\section{ANEXO A - Garantia Física do Sistema}

A metodologia de cálculo da garantia física dos novos empreendimentos de geração do SIN consiste nos seguintes passos:

D Determinação da oferta total de garantia física do SIN, por meio de simulação estática da operação do sistema hidrotérmico, ajustada para a igualdade do custo marginal de operação (CMO) médio anual e custo marginal de expansão (CME), admitida uma tolerância;

- Verificação do atendimento da restrição de Garantia de Suprimento ao Mercado, representada por um Risco máximo de 5\% de ocorrência de qualquer déficit.

- Rateio da oferta total (ou garantia física do SIN), somatório das cargas críticas do SIN, em dois blocos: oferta hidráulica - EH e oferta térmica - ET;

- Rateio da oferta hidráulica entre todas as UHE proporcionalmente às suas energias firmes, obtidas com auxílio do modelo MSUI, por simulação a usinas individualizadas do sistema integrado puramente hidrelétrico;

- Rateio da oferta térmica entre as UTE de forma análoga ao cálculo da oferta térmica, limitado à disponibilidade máxima de geração contínua de cada UTE e com o eventual excedente de oferta sendo distribuído entre as demais UTE na proporção de suas garantias físicas.

Desse modo, a determinação da energia assegurada independe da geração real e está associada às condições que cada usina pode fornecer ao sistema no longo prazo, assumindo um critério específico de risco de não atendimento do mercado - déficit - ("critério de garantia"). Este risco considera principalmente a variabilidade hidrológica à qual a usina está submetida.

A simulação da operação do sistema hidrotérmico é então realizada estaticamente considerandose todas as usinas e interligações como existentes no sistema por um período de estudo de cinco anos. Usinas com graves impedimentos para início da construção e/ou usinas em processo de devolução da concessão são excluídas e são adicionados os novos empreendimentos para os quais se deseja calcular a garantia física. Para retirar a memória do sistema, em termos de armazenamentos iniciais e tendência hidrológica, inclui-se um período estático inicial de 10 anos antecedendo ao de estudo e por fim se adiciona um período estático final de 5 anos, após o período de estudo, para a estabilização da função de custo futuro. 
São considerados dois grandes blocos regionais no processo iterativo de ajuste da oferta total: Sul e Sudeste/Centro-Oeste/Acre/Rondônia, e Norte/Manaus e Nordeste, mantendo-se fixa a oferta dos subsistemas. O processo converge quando ao menos um subsistema de cada bloco regional atende ao critério de igualdade entre $\mathrm{CMO}$ e $\mathrm{CME}$, admitida uma tolerância de atendimento aos critérios de garantia de suprimento estabelecido pelo CNPE. O somatório da carga dos subsistemas, ajustada para atendimento aos critérios de garantia de suprimento, é a carga crítica.

Realiza-se então um rateio da oferta total separando-a em dois grandes blocos: hidráulico (EH) e térmico $(\mathrm{ET})$. Os fatores hidráulicos $(\mathrm{FH})$ e térmicos $(\mathrm{FT})$ correspondem à participação de cada bloco na geração total, calculados com uma ponderação pelo $\mathrm{CMO}$, o qual é obtido através dos resultados do NEWAVE.

Equações para o cálculo da oferta hidráulica:

$$
\begin{gathered}
E H=F H x \sum_{s=1}^{n s s} \text { ccritica }_{s} \\
F H=\frac{\sum_{s=1}^{4} \sum_{i=1}^{12} \sum_{j=11}^{15} \sum_{k=1}^{2000} g h(i, j, k, s) \cdot \operatorname{cmo}(i, j, k, s)}{\sum_{s=1}^{4} \sum_{i=1}^{12} \sum_{j=1}^{15} \sum_{k=1}^{2000}\left[g h(i, j, k, s)+\sum_{l=1}^{n t(s)} g t(i, j, k, l, s)\right] \cdot \operatorname{cmo}(i, j, k, s)}
\end{gathered}
$$

Equações para o cálculo da oferta térmica:

$$
\begin{gathered}
E T(t, s)=F T(t, s) x \sum_{s=1}^{n s s} \operatorname{ccritica}_{s} \\
F T(t, s)=\frac{\sum_{s=1}^{4} \sum_{i=1}^{12} \sum_{j=11}^{15} \sum_{k=1}^{2000} g t(i, j, k, s) \cdot \operatorname{cmo}(i, j, k, s)}{\sum_{s=1}^{4} \sum_{i=1}^{12} \sum_{j=11}^{15} \sum_{k=1}^{2000}\left[g h(i, j, k, s)+\sum_{l=1}^{n t(s)} g t(i, j, k, l, s)\right] \cdot \operatorname{cmo}(i, j, k, s)}
\end{gathered}
$$

onde:

$\mathrm{s}=$ subsistema 
nss $=$ número de subsistemas

$\mathrm{FH}=$ fator hidrelétrico

$\mathrm{i}=$ mês

$j=$ ano

$\mathrm{k}=$ série

$\mathrm{t}=$ usina térmica

gh = geração hidráulica total (controlável + fio d'água + vazão mínima)

gt $=$ geração térmica total (inflexibilidade + geração flexível)

cmo = custo marginal de operação

$\mathrm{nt}(\mathrm{s})=$ número de térmicas do subsistema $\mathrm{s}$

$\mathrm{FT}(\mathrm{t}, \mathrm{s})=$ fator térmico da usina termelétrica $\mathrm{t}$

Para determinação da garantia física de cada usina, a oferta hidráulica (EH) é rateada pelo conjunto das usinas hidrelétricas da configuração, proporcionalmente à energia firme de cada usina. A energia firme corresponde à geração média nos meses do período crítico, obtida por simulação a usinas individualizadas do sistema integrado puramente hidrelétrico, utilizando séries de vazões históricas e limitada ao valor da disponibilidade de geração máxima da usina. Caso a usina possua um reservatório de regularização com usinas a jusante, poderá haver um acréscimo de energia nessas usinas, incorrendo em um benefício indireto (BI), o qual é calculado pela diferença entre o somatório da energia firme das usinas a jusante na cascata antes e depois da entrada da usina em questão. A garantia física é, portanto, obtida da soma da GFlocal com o BI.

Para o rateio do bloco termelétrico, a garantia física deverá ser limitada ao valor de sua disponibilidade máxima e de sua geração contínua $\operatorname{Dmax}_{\mathfrak{t}}$, como mostrado na seguinte equação:

$$
\operatorname{Dmax}_{t}=\operatorname{Pot}_{e f} x F C_{\text {max }} x(1-T E I F) x(1-I P)
$$

onde:

$\operatorname{Pot}_{\mathrm{ef}}=$ potência efetiva da usina

$\mathrm{FC}_{\max }=$ fator de capacidade máximo da usina

TEIF = taxa equivalente de indisponibilidade forçada

IP = indisponibilidade programada

A oferta térmica deve ser compatibilizada de acordo com a disponibilidade máxima do empreendimento e o restante é dividido nas demais termelétricas seguindo o mesmo raciocínio. 
Para as termelétricas com inflexibilidade total, o Custo Variável Unitário - CVU pode ser interpretado como nulo do ponto de vista "sistêmico", devido ao despacho mínimo obrigatório (por razões econômicas) que, para inflexibilidade total, alcança a capacidade máxima de geração contínua. Nesse pressuposto, a garantia física é dada pela equação:

$$
G F=\frac{\sum_{m=1}^{12} \operatorname{Disp}_{m}}{12}
$$

onde :

Dispm $=$ disponibilidade mensal declarada pelo gerador dado em MWmédios.

No caso de PCH pertencente ao MRE, os critérios de cálculo de garantia física são estabelecidos pela Portaria MME 463/2009. A equação para cálculo de usinas que se encontram em operação comercial é dada por:

$$
G M=\frac{12}{8760} \sum_{i=1}^{m} \frac{E_{g r_{i}}}{m}
$$

Onde:

GM = geração média de energia elétrica calculada;

$E_{g r_{i}}=$ montante de energia gerada no mês i referido ao ponto de conexão (MWh) e registrado na CCEE;

$\mathrm{i}=$ mês correspondente ao registro do montante de energia gerada; e

$\mathrm{m}=$ quantidade de meses até o último mês do período de análise, múltiplo de 12 , com registros na CCEE de montantes mensais de energia gerada.

No caso da energia eólica, as séries de dados de velocidade de vento, pressão do ar e temperatura ambiente, registradas com a precisão requerida para avaliação do potencial de energia eólica, ainda são relativamente pequenas, raramente alcançando um período superior a 3 anos, o que impede as simulações estocásticas da geração eólica ${ }^{27}$, integrada ao sistema interligado hidrotérmico nacional, com o Modelo NEWAVE.

\footnotetext{
${ }^{27}$ Para se efetivar a representação estocástica da oferta eólica é preciso reconstruir séries históricas de velocidade do vento, o que é possível com a utilização de modelos de Mesoescala. Para maior detalhamento da metodologia, consultar a Referência "Using the seasonal diversity between renewable energy sources to mitigate the effects of Wind generation uncertainties" - D.S. Ramos; E. Guarnier e Lucas T. Witzler - IEEE PES T\&D LA Montevideo 2012 (Uruguay).
} 
Desta forma, de acordo com a Portaria MME 131 de 2013, a produção anual de energia certificada deve considerar o abatimento das perdas por conta da disposição dos Aerogeradores, das condições meteorológicas locais, da densidade do ar, da degradação das Pás e das perdas aerodinâmicas do próprio Parque e dos efeitos esteira e turbulência de outros Parques, entre outros.

Para os Leilões de Energia de Reserva e de Energia Nova, a garantia física de energia das Usinas Eólicas será calculada pela aplicação da seguinte fórmula:

$$
G F=\frac{\left[P 90_{a c} x(1-T E I F) x(1-I P)-\Delta P\right]}{8760}
$$

Sendo:

GF = Garantia Física de Energia, em MW médio;

$\mathrm{P} 90_{\mathrm{ac}}=$ produção anual de energia certificada, em $\mathrm{MWh}$, referente ao valor de energia anual com uma probabilidade de ocorrência igual ou maior a noventa por cento para um período de variabilidade futura de 20 anos, constante da Certificação de Medições Anemométricas e de Produção Anual de Energia;

TEIF = Taxa Equivalente de Indisponibilidade Forçada;

IP = Indisponibilidade Programada;

$\Delta \mathrm{P}=$ Estimativa Anual do Consumo Interno e Perdas Elétricas até o Ponto de Conexão da Usina Eólica com o Sistema Elétrico, em MWh.

Nos leilões de energia nova e de fontes alternativas realizados até 2012, o compromisso firme de entrega de energia deveria ser menor ou igual aos valores médios estimados de produção de energia apresentados na certificação da medição anemométrica, adotando-se um critério de valoração tal que a produção anual de energia certificada referia-se ao valor de energia anual com probabilidade de ocorrência igual ou maior a cinquenta por cento.

Para fins de revisão dos montantes de garantia física de energia dos empreendimentos, serão consideradas as seguintes hipóteses:

I - o empreendimento apresentar uma geração média de energia elétrica nos seus primeiros 48 meses de operação comercial inferior a $80 \%$ ou superior a $120 \%$ da garantia física de energia vigente; 
II - o empreendimento apresentar uma geração média de energia elétrica a partir dos seus 60 meses de operação comercial inferior a $90 \%$ ou superior a $110 \%$ da garantia física de energia; III - o empreendimento apresentar modificação comprovada das características técnicas, com consequente alteração da sua capacidade de produção de energia elétrica.

Para as hipóteses dos incisos I e II, os novos montantes de garantia física de energia dos empreendimentos hidrelétricos serão considerados para fins de alocação no MRE e para verificação do lastro dos respectivos Contratos de Venda de Energia.

Cada redução da Energia Assegurada está limitada a 5\% e a redução máxima se limita a 10\% da Assegurada Original durante o período de concessão. No caso de usinas hidrelétricas não despachadas centralizadamente e não pertencentes ao MRE a garantia física pode ser reduzida de modo que represente a capacidade real de geração da usina, assim não há o limite de redução. 